Florida International University FIU Digital Commons

\title{
La mujer en defensa de la mujer: voces femeninas del romanticismo cubano (Poesía y cuento)
}

Luis Marcelino Gómez

Florida International University, lgomez03@fiu.edu

DOI: $10.25148 /$ etd.FI08081520

Follow this and additional works at: https://digitalcommons.fiu.edu/etd

Part of the Spanish and Portuguese Language and Literature Commons

\section{Recommended Citation}

Gómez, Luis Marcelino, "La mujer en defensa de la mujer: voces femeninas del romanticismo cubano (Poesía y cuento)" (2001). FIU Electronic Theses and Dissertations. 55.

https://digitalcommons.fiu.edu/etd/55 
LA MUJER EN DEFENSA DE LA MUJER:

VOCES FEMENINAS DEL ROMANTICISMO CUBANO

(POESÍA Y CUENTO)

A dissertation submitted in partial fulfillment of the requirements for the degree of DOCTOR OF PHILOSOPHY

in

SPANISH

$\mathrm{by}$

Luis Marcelino Gómez 
To: Dean Arthur W. Herriott

College of Arts and Sciences

This dissertation, written by Luis Marcelino Gómez, and entitled La mujer en defensa de la mujer: voces femeninas del romanticismo cubano (poesía y cuento), having been approved in respect to style and intellectual content, is referred to you for judgment.

We have read this dissertation and recommend that it be approved.

Florence L. Yudin

Leonel A. de la Cuesta

Reinaldo Sánchez, Major Professor

Date of Defense: November 27, 2001

The dissertation of Luis Marcelino Gómez is approved.

Dean Arthur W. Herriott College of Arts and Sciences

Dean Douglas Wartzok University Graduate School

Florida International University, 2001 
(C) Copyright 2001 by Luis Marcelino Gómez

All rights reserved. 


\title{
DEDICATORIA
}

\author{
A Juana Pastor, que fue la primera, \\ y a Adelaida del Mármol, que fue la más joven.
}


RECONOCIMIENTO

\begin{abstract}
Quiero expresar el agradecimiento a mis estimados profesores, los Dres. Reinaldo Sánchez, Major Professor, Leonel Antonio de la Cuesta y Florence L. Yudin, pilares de mi formación como hispanista en el Departamento de lenguas modernas de la Universidad Internacional de la Florida; a la Sra. Ana Arteaga y al personal de préstamos entre bibliotecas de F.I.U.; y a Mónica Lamadriz del F.I.U. G.C. Computer Center; así como a Esperanza de Varona, directora de la Cuban Heritage Collection de la Otto G. Richter Library en la Universidad de Miami y, muy especialmente, -en la misma institución- a Lesbia Orta Varona sin cuya desinteresada e incalculable ayuda esta investigación no hubiera podido concluirse.
\end{abstract}


ABSTRACT OF THE DISSERTATION

WOMEN DEFENDING THEMSELVES:

CUBAN ROMANTIC FEMININE VOICES

(POETRY AND SHORT STORIES)

by

Luis Marcelino Gómez

Florida International University, 2001

Miami, Florida

Professor Reinaldo Sánchez, Major Professor

Throughout history, women have played an important role in literature. Nevertheless, since Sappho's poetry until now, feminine voices have had to struggle for recognition of their works.

Before the nineteenth century, women were almost ignored in Spanish literature. Society kept them as "ángeles de la familia," taking care of their homes, husbands, and children. Some of them, such as María de Zayas y Sotomayor in Spain and Sor Juana Inés de la Cruz in Mexico, complained about their situation in their writings. However, they expressed their fight not as a generation but as individuals.

In the nineteenth century, the ideas and ideals of 
Romanticism, were brought to Latin America from Europe. Cuba was among those countries where the new movement took roots. Initiated by Gertrudis Gómez de Avellaneda, a group of women began to participate in literary reunions, and to found newspapers and magazines where works authored by women, dedicated to feminist ideas, were published. They indeed through literature started to live out womanhood in order to intellectually leave the ideological prisons where society had been keeping them.

This study scans the literary works of all Romantic women writers in Cuba. It specifically analyzes poetry and short stories, and investigates how these authors expressed themselves in their works against the patriarchal society, where they lived and wrote their books. An eclectic critical method has been used.

Findings were very revealing. Only three of the fourteen writers studied in my dissertation had been previously mentioned by major critics. Most of them had been ignored. However, the greatest discovery was that they prompted something new: For the first time they projected themselves as a group, as a collective consciousness, and this fact established a difference with former women writers in Cuban literature before Romanticism. In other words, they produced a 
"Renaissance" in Cuba's literature. In spite of how they lived between 1820 and 1900, their struggles for women's rights have linked them to our current times. 


\section{ÍNDICE}

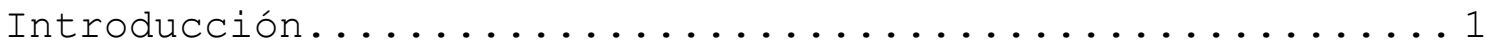

Capítulo I. Las primeras románticas.................... 11

1. Voces femeninas previas al período romántico.

¿N Cruz o marquesa de Jústiz de Santa Ana? Juana Pastor:

exégesis del primer poema feminista de la lírica

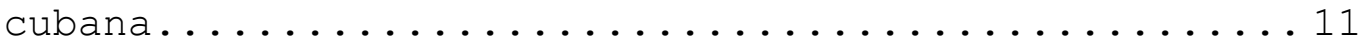

2. Gertrudis Gómez de Avellaneda.............. 15

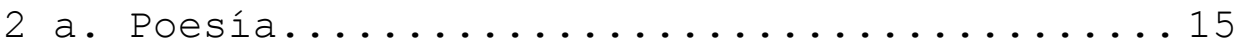

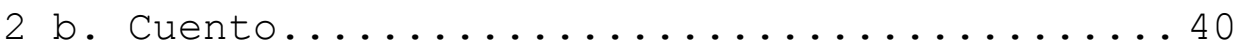

3. Mercedes Valdés Mendoza....................56

4. Luisa Molina......................68

Capítulo II. Segundo Romanticismo................ 76

1. Úrsula Céspedes de Escanaverino.............76

2. Luisa Pérez de Zambrana.....................99

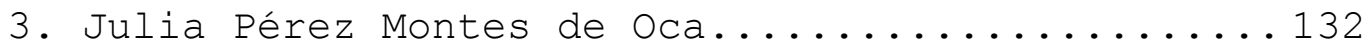

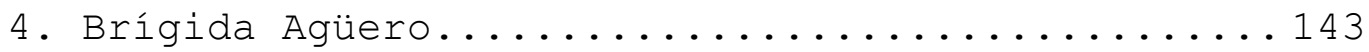

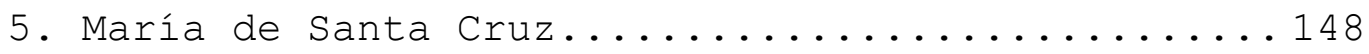

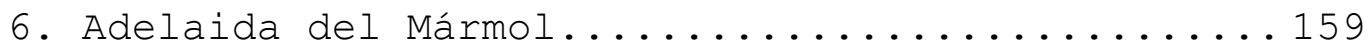

Capítulo III. Declinación del Romanticismo...........184

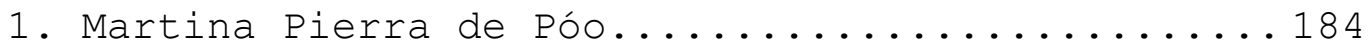

2. Aurelia Castillo de González................ 195 


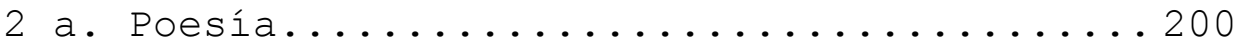

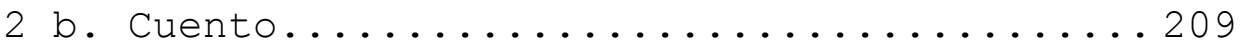

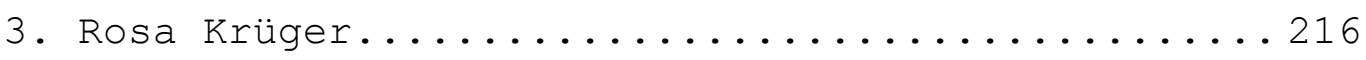

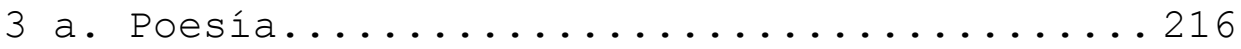

3 b. Prosa: ensayo y traducciones...........224

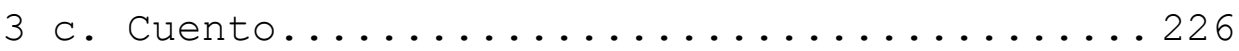

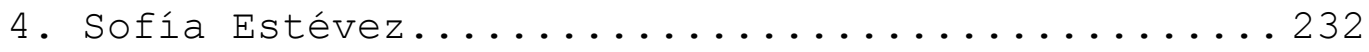

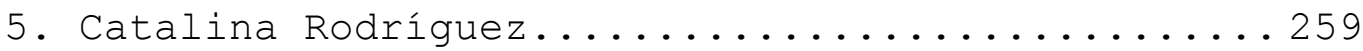

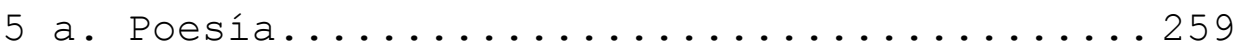

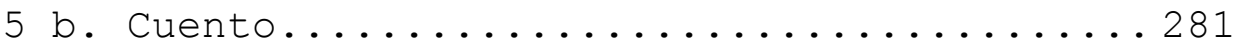

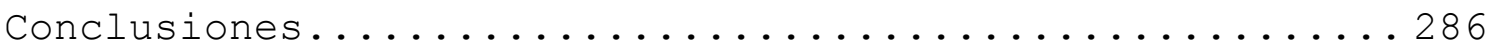

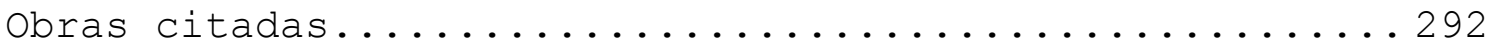

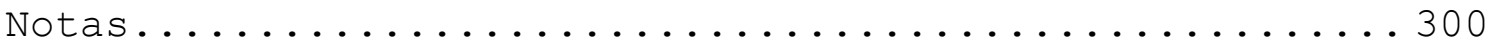

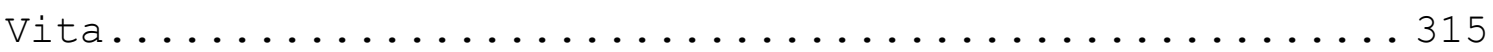


Nota :

En los textos que pertenecen a otros autores se ha respetado la ortografía original. 


\section{Introducción}

La mujer siempre ha desempeñado un papel importante en la literatura universal. Sin embargo, desde la obra de Safo (Lesbos ¿625-580 a. de J. C.?) hasta la novela más reciente de Mireya Robles (Guantánamo, Cuba, 1934), las voces femeninas han debido imponerse y sobrevivir en un mundo patriarcal. Han tenido que hacerse sentir en un esfuerzo por romper barreras y círculos de dominio masculino. Ejemplo de esto lo encontramos en nombres tan importantes como Santa Teresa de Jesús y María de Zayas y Sotomayor en España, o Sor Juana Inés de la Cruz, Alfonsina Storni, Julia de Burgos o Gabriela Mistral en Hispanoamérica.

La literatura cubana es reflejo de tal circunstancia. Cuando Juan J. Remos en su Proceso histórico de las letras cubanas se refiere a quienes primero vierten su visión de la isla, todos son, sin distinción, varones: Cristobal Colón y su Diario, a través del padre Fray Bartolomé de las Casas; Bernal Díaz del Castillo y su Verdadera Historia de los Sucesos de la Nueva España; Antonio Herrera y sus Décadas; O Juan Castellanos y sus Elegías de Varones Ilustres de Indias (27). Igualmente sucede con "la primera obra literaria escrita en Cuba, que ha llegado hasta nosotros: Espejo de Paciencia, poema épico, debido a Silvestre de Balboa Troya y Quesada, y 
que fue producido en 1608" (32). Como los anteriores, era hombre y europeo. Y hombre es el primer poeta cubano nacido hacia finales del siglo XVII, aunque escribe ya en pleno siglo XVIII: "José Surí y Aguila (Santa Clara, 1696-1762), que unía a su condición de elaborador del poema, la de repentista, de improvisador; por lo que hizo varias poesías de circunstancias" (Remos 41). Surí fue médico y causó asombro en La Habana, al aprobar el examen que se exigía entonces ante el Protomedicato, "no sólo [por] lo que sabía, sino [por]que su exposición la hiciera en verso improvisado" (Remos 41). Un año después de la muerte de José Surí y Águila se da a conocer, supuestamente, el primer escrito creado por mujer en el archipiélago cubano.

Según Max Henríquez Ureña, en el volumen I de su Panorama histórico de la literatura cubana, la primera cubana que publicó un trabajo poético fue N. Cruz, en 1763, en México (1: 59). El dato anterior aparece en la Biblioteca hispano-americana septentrional, obra de José Mariano Beristán de Souza publicada también en México, entre 1816 y $1821^{1}$ (2: N. pág.) . La cubana, según Henríquez Ureña, oriunda de La Habana, se inspiró en la toma de su ciudad por los ingleses durante el siglo XVIII ${ }^{2}$ (1: 59). El manuscrito, informa, se conserva en la Academia de Historia de Madrid. Su título es 
Dolorosa y métrica expresión del sitio y entrega de La Habana. En una nota al pie de página, comenta Henríquez Ureña que Beristán designa también ese trabajo como La América dolorosa, y opina que el error en el nombre de la obra que da Beristán es "cosa no extraña en él" (1: 59). Llama la atención el hecho que José Lezama Lima, en su Antología de la poesía cubana, hable de una autora que escribió una obra con igual título que el expuesto por Henríquez Ureña y que Lezama Lima atribuye a la marquesa de Jústiz de Santa Ana. Como los versos que el crítico dominicano estudia, y cita como de N. Cruz: "muchos Consejos de guerra, y faltó guerra y consejos" (1: 59), son versos que, además del título, resultan similares a los que aparecen en la antología de Lezama: "muchos consejos de Guerra, /faltando Guerra, y Consejo" (1: 360); se puede pensar que ambos investigadores se están refiriendo a igual persona y obra.

En los antecedentes aportados por Lezama, la creadora, habanera también, nació en 1733 y "[m] urió hacia 1807." Por los datos que toma de Juan Francisco Manzano, se sabe que la marquesa de Jústiz de Santa Ana "casaba a los esclavos de su servidumbre, después de darles educación, protegiéndolos cuanto podía al obtener la libertad" (1: 155). Se desconoce el porqué de la confusión lo cual, por otra parte, no es el 
objetivo de este trabajo, aunque nos importe para determinar con precisión que hubo obra escrita por mujer antes de la época que nos atañe. Pero, según Alberto Rocasolano, en Poetisas Cubanas, "[e]n verdad la poesía femenina en Cuba alcanza existencia realmente con la obra de Gertrudis Gómez de Avellaneda" (12). Interesante resulta que además de lo ya dicho, se mencione a otra autora, anterior al período romántico. Es el caso de Juana Pastor, que aparece en la introducción de Antonio López Prieto a su Parnaso Cubano, de 1881, donde se cita a una "poetisa sorprendente improvisadora, una mujer de color, mestiza, que logró alguna instrucción, al grado de obtener un colegio y ser profesora de las damas más distinguidas de su época y muy versada en latín" (LIV). Esta mujer, de ascendencia africana, es mencionada también por Francisco Calcagno en su Diccionario Biográfico Cubano, de 1878, como mulata, profesora distinguida y poetisa de La Habana. Según Armas", fue "la primera que hizo resonar el arpa cubana en el siglo pasado" (cit. en Calcagno 487). Se culpa a la falta de imprenta de la época el que sus poesías y su prosa, -que se cree, escribió mucha-, se perdieran. El 27 de noviembre de 1815, Juana Pastor improvisó unas décimas que aparecen en Antonio López Prieto, décimas que constituyen la 
primera manifestación femenina de la lírica cubana en defensa de la mujer.

En ningún texto se hace mención de Juana Pastor como la primera poeta cubana feminista, pionera en estas luchas de la mujer intelectual de la isla ${ }^{5}$ A tal punto llega este desconocimiento que se encuentran trabajos como los de Angelina Gatell, quien, en su breve ensayo "La poesía femenina del romanticismo cubano," expresa que "[e]n el lento y penoso surgir de las letras cubanas - cuyo proceso se halla estrechamente vinculado a los acontecimientos históricos, políticos y sociales del país-, no aparece ningún nombre de mujer," y agrega: "[t]ienen que transcurrir dos siglos -el tiempo que va desde la aparición del primer poema escrito en Cuba, Espejo de paciencia, debido a la pluma de Silvestre de Balboa Troya y Quesada, hasta la llegada del Romanticismo [...] para que surja la primera voz femenina en la historia de la poesía cubana" (541-542). Se refiere la crítico a textos de valor, pero olvida a las habaneras anteriores cuando dice: "[y] es en el Romanticismo cuando los vientos alisios transportan hasta la vieja España el eco de [...] [estas] primeras voces femeninas" (542). Sin embargo, menciona Gatell a varias de las figuras de este período. Y lo expresa así: "[l]legan a la península, impulsados por su propia valía, los 
nombres de Luisa Pérez de Zambrana [...], Mercedes Valdés Mendoza, Luisa Molina, Brígida Agüero y Adelaida del Mármol" (542). Por supuesto habla de la Avellaneda a cuya obra y vida dedica el resto de su ensayo. Estos nombres aparecen en algunas, pocas, recopilaciones de la época y, en mucha menor cuantía, en investigaciones actuales, como la de cintio Vitier, quien en su antología Los grandes románticos cubanos, de 1960, sólo escoge a Gertrudis Gómez, a Luisa Pérez de Zambrana y a la hermana de ésta, Julia Pérez Montes de Oca. Emilio Carilla, por su parte, en El romanticismo en la América hispánica, apenas se ocupa de las mujeres románticas. A quien menciona más, y no lo hace mucho, es a Gertrudis Gómez de Avellaneda, como escritora y, a su vez, como traductora de algunos poemas de Víctor Hugo, del francés, y algunos de Byron, del inglés, específiclamente su son of the sleepless con el título de «A la luna». Cita a la condesa de Merlín (María de las Mercedes Santa Cruz) como autora de una novela escrita originalmente en francés, parte de una obra mayor, París 1831; a Mercedes Matamoros como traductora de las «Melodías Hebreas» de Byron, y a Salomé Ureña de Henríquez a quien nombre para hablar de quienes tocan el tema del indianismo típicamente romántico ${ }^{6}$. Hace también breves anotaciones sobre la novelista romántica colombiana soledad 
Acosta de Samper (1833-1903) en relación a uno de sus cuentos "Luz y sombra;" menciona a la argentina Juana Manuela Gorriti (1819-1892) por algunos de sus relatos: "Un drama en quince minutos, idilio y tragedia;" y nombra a Juana Borrero para contarla entre los "famosos poetas modernistas" (II: 187). Salvo estas citas, cuando Carilla divide su estudio en las figuras de primera, segunda y tercera generación romántica, sólo menciona a Gertrudis Gómez de Avellaneda, que dicho sea de paso no aparece entre los que considera "grandes románticos" (2: 145) que, según él, son: Sarmiento, Juan Vicente González, Gregorio Gutiérrez González, Juan Montalvo, José Hernández, Jorge Isaacs, Ricardo Palma, Manuel de Jesús Galván, Juan Antonio Pérez Bonalde, Manuel González Prada y Juan Zorrilla de San Martín. Es decir, para el crítico argentino, el romanticismo en Hispanoamérica es netamente masculino. No tiene explicación cómo, con la obra de la camagüeyana que abarca novela, teatro, cuento, memoria, costumbres, viajes y una gran poesía, este investigador no le haya dedicado nada más que breves renglones.

Un estudio completo de las voces femeninas del romanticismo cubano que cultivaron el cuento y la poesía no existe. Vera M. Kutzinski en "Caribbean theory and criticism" declara: 
[t]wo ground-breaking collections of Caribbean feminist criticism were published in 1990: Selwyn Cudjoe's Caribbean Woman Writers: Esays from the First International Conference (held in 1988 at Wellesley College) and Carole Boyce Davies and Elaine Savory Fido's out of the Kumbla: Caribbean Women and Literature. Both volumes are significant attempts at acknowledging the diversity of Caribbean women's writing. Even though their primary focus remains on the English-speaking West Indies, both collections also include essays on Dutch and

Hispanic Caribbean literature, two areas in which little serious critical work has been done to date [...]. (141), (énfasis nuestro).

Se han publicado trabajos aislados en relación con el tema como La novela criolla en las Antillas, de Isabel Hernández de Norman, que abarca la ficción novelística antillana pero, con la excepción de los estudios sobre María Mercedes Santa Cruz, Condesa de Merlín (1789-1852), y de Gertrudis Gómez de Avellaneda (1814-1873), ambas cubanas, el resto de los autores que incluye en su investigación son hombres. Lo mismo hace Marguerite C. Suárez-Murias en La novela romántica en Hispanoamérica. 
Salvo Gertrudis Gómez de Avellaneda, la más reconocida y difundida de las autoras caribeñas, del resto apenas se han realizado breves estudios -si acaso. En ocasiones sólo se hallan algunos versos antologados por no haberse publicado libro alguno o por la gran dificultad de encontrarlos, en caso de que existan. En otros, se sabe de las poetas por aparecer mencionadas en historias de la literatura, pero con muy escasas referencias.

El propósito de nuestro trabajo, circunscrito solamente a Cuba, es estudiar críticamente a las mujeres del período romántico que escribieron poesía y cuento cuya obra es casi desconocida. Se hace un acápite para cada autora y se describen las características del discurso femenino individual y colectivamente. A pesar de que se toman nombres tan conocidos como el de Gertrudis Gómez de Avellaneda (Cuba, 1814-Madrid, 1873), se da importancia a aquellas creadoras que no han sido analizadas con profundidad hasta el momento. Nuestra investigación recoge e incluye datos recolectados en archivos, bibliotecas y la prensa de la época.

Como punto de partida hemos decidido seguir la clasificación de Alberto Rocasolano, en Poetisas Cubanas, aunque se mencione alguna otra que dicho autor no incluye en su trabajo. 
En la exégesis de cada autora y, posteriormente, del conjunto, se utiliza una hermenéutica ecléctica. 


\section{Capítulo I: Las primeras románticas}

1. Si creemos a Max Henríquez Ureña, la primera mujer cubana que publicó un trabajo poético fue N. Cruz, en 1763, (1: 59) o, según José Lezama Lima, la marquesa de Jústiz de Santa Ana. Lo cierto es que el tema tratado entonces fue el de la toma de La Habana por los ingleses. Es Juana Pastor, quien el 27 de noviembre de 1815, como hemos explicado, efectúa la primera manifestación femenina de la lírica cubana en defensa de la mujer al improvisar las décimas siguientes ${ }^{7}$. Se citan no sólo por su valor histórico, sino por el contenido de este trabajo:

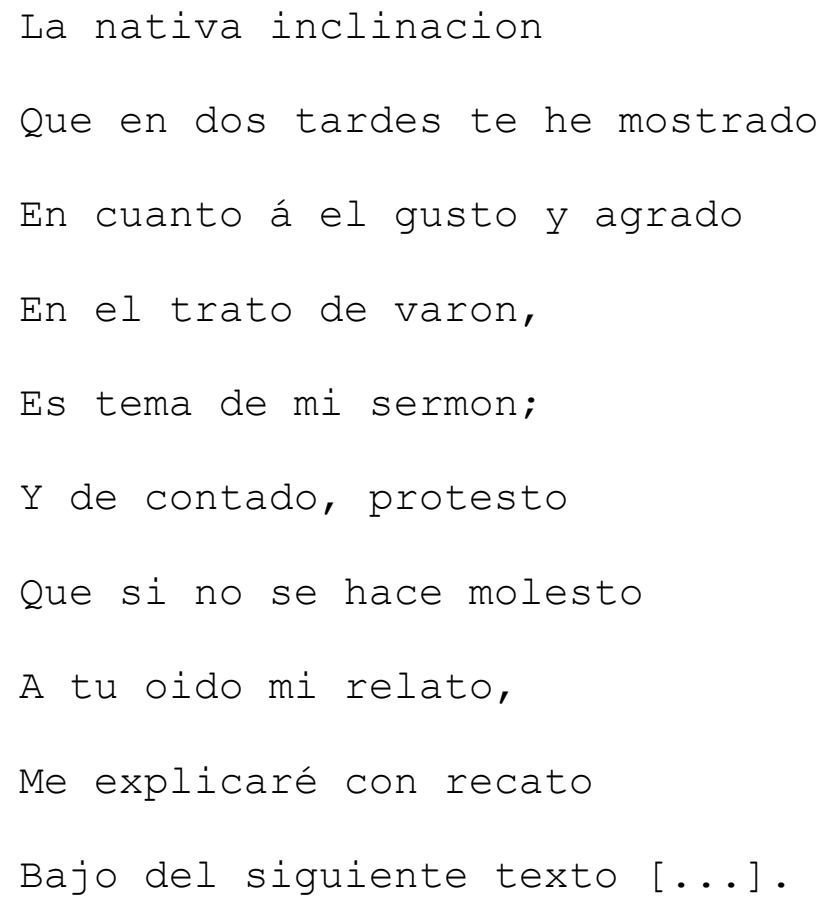


Desde los primeros versos, Pastor se refiere al "trato de varón;" y añade "de contado protesto" (énfasis nuestro); mas dice que hablará con cautela, y comenta la diferencia entre un sexo y el otro. Sabe ella, como mujer culta e inteligente, lo que puede ocurrirle. Obsérvese el punto de vista de López Prieto, quien, al referirse a esta mujer menciona que dominaba el latín en 1815, pero afirma de ella solamente que "logró alguna instrucción." Debió ser muy brillante esta poeta nacida hacia finales del siglo XVIII para que, siendo mulata, llegara a profesora y a ser considerada intelectual cuando aún había esclavitud en Cuba, para que creara y diera a conocer el texto que analizamos, 71 años antes de que aquélla se aboliera. El verso que sigue, en latín, que se encuentra entre una décima y otra, muestra la erudición de Juana Pastor:

Delitioe moe esse cum filiis hominum.

Dijo Dios, y con justicia, Digno es que el Angel se asombre, Que era su delicia el hombre; Que era el hombre su delicia: ¡Qué remarcable caricia! ¿Luego que debo hacer yo, Cuyo sexo Dios formó 
Para compaña de aquel

Que el llama delicia de él?

¿Puedo abominarlo? Nó.

Indirectamente, al exponer la creación del hombre, según la Biblia, Pastor, preguntándose a sí misma, dice lo que piensa del varón que al parecer condena y aborrece. La negación final, expresada con fuerza ante el interlocutor, no es más que una evasión de la verdad escondida que de todas formas queda dicha. Y sigue la poeta:

Compadezco del impío,

Me lastimo del inepto,

Doy incienso al predilecto,

Y del soberbio me rio:

Tambien sagaz me desvio

Del grosero rasgador

Que infiero viole mi honor,

Mas siempre con fé sencilla

Por saber soy su costilla;

Que es fuerza le tenga amor.

Genialmente está explicado

De mi carácter lo puro,

Y creo quedes seguro

Que es seguro lo estampado: 
Ordena que tu mandado

Sabrá cumplir con primor

La que disfruta el honor,

aunque aldeana infeliz

De estar a tus plantas Ruiz,

Firmada: Juana Pastor. (LIV-LV)

La poeta, a principios del siglo XIX, se apropia de un papel que, en la época que vive, corresponde al masculino: se compadece de algunos hombres, se ríe de los soberbios y se enfrenta a ellos aunque "es fuerza le[s] tenga amor." Al final del poema, esta mujer de 1815, profesora, poeta, prosista, que domina el latín, dice ser una "aldeana infeliz," que se coloca a las plantas del interlocutor. Queda, no obstante, sin mucho enmascaramiento, la protesta ante la religión o más bien de Dios, que ha escogido al varón, a pesar de que fue quien su "sexo [...] formó/Para compaña de aquel" (LIV) .

El trabajo de esta poeta no parece haber influenciado a las líricas cubanas posteriores que, a partir de Gertrudis Gómez de Avellaneda, desarrollaron el movimiento romántico en Cuba. Pero la escasa obra de Pastor nos sirve para hablar de un antecedente importante. Juana Pastor vivió inmersa en un mundo patriarcal donde sufrió una triple opresión: por ser mujer, por ser mestiza y por ser intelectual a inicios del 
siglo XIX, aún antes de la abolición de la esclavitud en Cuba, que sucede en 1886 (Castellanos 165); mas ello no le impidió escribir y manifestarse. Creo que debería pues tenerse en cuenta en futuros estudios de poesía cubana.

\section{Gertrudis Gómez de Avellaneda.}

2 a. Poesía.

Todo estudio serio sobre poesía hispana cita, entre sus más importantes creadores, a Gertrudis Gómez de Avellaneda. Nuestro trabajo, por tanto, no la abordará en detalle para concentrarse en otras autoras de igual período que, aparte de Luisa Pérez de Zambrana y de su hermana Julia Pérez Montes de Oca, están hoy olvidadas o apenas se mencionan.

Gertrudis Gómez de Avellaneda, cuyo nombre completo era

María Gertrudis de los Dolores Gómez de Avellaneda y de Arteaga, y que fuera conocida por Tula, nació en Puerto Prícipe, hoy Camagüey, el 23 de marzo de 1814 y murió en Madrid el $1^{\circ}$ de febrero de 1873. Sus restos se encuentran en el cementerio de San Fernando de Sevilla, en España.

Vivió en Cuba hasta su adultez. Según Hugh A. Harter en Gertrudis Gómez de Avellaneda: "[h]er mother [Francisca de Arteaga y Betancourt] was of a well-to-do patrician family long established in Cuba" (18). De don Manuel Gómez de 
Avellaneda, comandante de la flota española en la parte central de la isla, el mismo crítico afirma que "[he] was of a noble spanish family [...] descent from the royal family of Navarre and the high aristocracy of Vizcaya (19). Este abolengo y riqueza, rodeada de servidumbre y de criados negros, muchos de ellos todavía esclavos, es la que le permite su formación en casa donde tuvo entre sus tutores a José María Heredia. Esta educación la situó muy por encima de la mayoría de sus contemporáneas en la isla y en Europa. Gertrudis Gómez de Avellaneda, cuya "precocidad como creadora despertó asombro en su momento, ya que "[a] los siete años, sin saber escribir, dictaba versos [y a] los 8 años compuso un cuento con el título de El gigante de 100 cabezas" (Lezama Lima 2: 69), tempranamente aprendió francés y fue una lectora voraz. Leyó, en la lengua original, a los escritores franceses en boga: Chateaubriand, Victor Hugo, Aurora Dupin "George Sand," Lamartine, Rousseau y, en traducción francesa, a Sir Walter Scott y a Lord Byron. Es llamativo para su edad y su tiempo cómo la Avellaneda, una adolescente de sólo 15 años, cuando la familia trata de casarla con un pariente, -el cual según su autobiografía a Cepeda", era: "el soltero más rico de Puerto Prícipe, que muchas deseaban" (146) y, además, "un hombre de buen [aspecto] personal y [que] se le disputaba el mejor 
partido del país" (146)-, ella lo rechazó "en vísperas... [cuando] ...matrimonio; casa, ajuar, dispensa, todo estaba preparado" (157). Este rechazo la condujo a perder le herencia por parte del abuelo, que era la quinta parte de su fortuna, y la crítica de tíos, primos y de la familia íntegra.

Cuando se marcha de Cuba se encuentra con el romanticismo en pleno apogeo. Apenas con 27 años se da a conocer con un libro de poesía y una novela, lo que significó la entrada a un territorio que era hostil a las mujeres. Un terreno difícil donde florecía "la tradición española profundamente misógina [que] encabezaba una reacción que era de esperar contra la mujer en la literatura" (Kirkpatrick 94). En ella, como en todas las creadoras de su tiempo, tuvo que subvertirse el Yo, superar en los demás y, particularmente en ellas mismas, la idea de la mujer como ser doméstico -objeto- educada para el hogar y la familia, pero nunca para la expresión del saber. La poeta supo, sin embargo, enfrentarse a su medio. Harter se refiere a estas luchas por parte de ella y la elogia como "this woman whose struggle for woman's rights, for justice and whose interest in a whole range of social problems are very much part of our present concerns" (N. pág.).

Con motivo de cumplirse un centenario de la muerte de Gertrudis Gómez de Avellaneda se dictaron en Madrid, en 1973, 
unas conferencias en la Fundación Universitaria. Allí, una estudiosa de la Avellaneda, Carmen Bravo-Villasante, afirmó que se homenajeaba a una mujer "que fue una de las más extraordinarias escritoras de la literatura española" (4), (énfasis nuestro), y, además, "la romántica más romántica de todas las figuras del romanticismo en lengua española" (9). La Avellaneda legó una amplia obra que comprende 21 obras de teatro (15 dramas y 6 comedias), 7 novelas -entre ellas $\underline{\text { Sab }}^{9}$, que es la primera novela antiesclavista de América-, y Guatimozín, que convirtió en una leyenda, por no haber podido ser revisada, lo que aparece como nota explicativa al pie de la misma-, así como varios tomos de poesía, de cuentos, memorias, autobiografía, loas, artículos de crítica y devocionarios. Por lo anterior, el poeta Emilio Ballagas (1908-1954) añade: "la novela cubana tiene en ella su primer cultivador. Y el cuento y la comedia. Y la traducción" (148). La Avellaneda dejó, además, un extenso epistolario que la convirtió, según Bravo-Villasante, en "la primera epistológrafa española, después de Santa Teresa" (12), y agregó que, si "hubiese nacido en Francia, o hubiese pasado de Cuba a París en lugar de pasar por Madrid, hubiera sido la Madame de Sevigné del siglo XIX" (12). Su estudio, obviamente, es esencial. 
Gertrudis Gómez de Avellaneda constituye la autora más conocida del período no sólo en el Caribe hispano, sino también en España. Había partido de Cuba a los 22 años de edad, en 1836 10 -Lezama afirma que entonces tenía 24- (2: 71). Hugh A. Harter ${ }^{11}$ explica: "[i]n her own day, such well-known authors as Zorrilla, Juan Valera, Nicasio Gallego, Gil y Carrrasco, and Pastor Díaz saw her as an extraordinary, even phenomenal, figure. She was publicly acclaimed the greatest woman poet of all Spanish literature" (N. pág.). A lo que agrega más adelante: "despite such formidable contenders as Carolina Coronado and Rosalía de Castro in poetry, and Fernán Caballero and the Countess Pardo Bazán in the novel [...], [f]or all the excellence of their accomplishments, none of these women can match Tula in breadth and variety of literary achievement" (18). Su vida social fue tan intensa como la anterior. Baste señalar como cuenta Ondina Montoya de Zayas (basada en datos de Emilio Cotarelo y Mori), que el 26 de abril de 1855 Gertrudis Gómez de Avellaneda celebró sus bodas con el coronel Verdugo -ayudante de campo del rey Franciscoen el Palacio real y los padrinos fueron los propios monarcas (127). Este hecho, ocurrido diecinueve años después de haber llegado a la metrópoli, explica por sí solo, la importancia que había adquirido en la corte. 
Por eso no resulta extraño el conocido comentario sobre ella de que "es mucho hombre esa mujer." Aseveración que provenía de una cultura patriarcal y misógina que desdeñaba lo femenino y que Lazo comenta así: "sólo una generalizadora identificación de todo lo femenino con lo endeble y lo superfluo, pudo sugerir a un escritor español de la época el masculinizante error de juicio que pretendía sugerir un elogio" (50). Rosario Rexach en su artículo "Una carta olvidada de la Avellaneda ${ }^{12}$," refiere que fue el escritor español Bretón de los Herreros, el autor de tan conocida afirmación (24). Florinda Álzaga agrega que esta expresión surgió "al calibrar la poesía vigorosa, profunda, sostenida, de versificación correctísima y vibrante de la Avellaneda, caso insólito cuyos poemas con pocas excepciones se salían del molde delicado y tierno de la usual poesía femenina" (291). Phyllis Zatlin Boring, en relación con esta expresión de Bretón de los Herreros, agrega que lo que ocurre es que: [1]os autores y críticos varoniles en general no pueden fácilmente aceptar la idea de que escritoras fuertes sean mujeres. Carolina Coronado no les plantea ningún problema; es débil y delicada -es decir-, «femenina». Pero crítico tras crítico ha dicho de Santa Teresa y Pardo Bazán que son 
«varoniles». Mientras tales comentarios reflejan el antifeminismo de los que hablan, es un homenaje a la Avellaneda misma que pertenece a la media docena de escritoras españolas que son «mucho hombre» (94)

Según Álzaga, "con la misma intención de alabanza declara Ferrer de los Ríos: No es la Avellaneda poetisa sino poeta" (291). Naturalmente, cualquier escritora estaba ocupando un puesto que era en aquellos momentos sólo concedido al hombre. Cuestión válida, incluso, en autoras que se oponían al romanticismo y lo que éste representaba para la liberación de la mujer. Fue el caso de Cecilia Böhl (Fernán Caballero), partidaria de lo conservador en sus obras a tal punto que, al inicio de su carrera, se negó por años a publicar. El hecho de que una mujer escribiera representaba entonces un enfrentamiento con la sociedad.

Los escritores de la época, no obstante, llegaron a ver a Gertrudis Gómez de Avellaneda como un igual, lo que "era en aquel sistema estimativo un honor" (Álzaga 292). Don Juan Nicasio Gallego afirmó en su tiempo: "[t]odo en sus cantos es nervioso y varonil; así, cuesta trabajo persuadirse que no son obra de un escritor del otro sexo. No brillan tanto en ellos los movimientos de ternura ni las formas blandas y delicadas propias de un pecho femenil" (cit ${ }^{13}$. en Álzaga 291). Nicomedes 
Pastor Díaz mantiene igual tono anterior cuando expresa: "[f]ue uno de los más ilustres poetas de su nación. Fue la más grande entre las poetisas de todos los tiempos" (cit. en Álzaga 291). Al considerar, en resumen, que escribía "como un hombre," estaban haciéndole un elogio; ya que lo femenino no tenía valor alguno, pues venía de alguien que "no pensaba," cuya función era estar en su casa, "surcir y bordar." Hartzenbush, que criticó algunos defectos de su drama Egilona, lo reflejó cuando dijo: "[e]sto juzgando la obra como de poeta y no como de poetisa; que si hubiéramos tenido presentes las consideraciones que se deben a una persona del bello sexo no hallaríamos palabras con que elogiarla" (cit. en Álzaga 291-292). Y así sucesivamente, hasta llegar a Zorrilla, quien la consideraba su igual.

Todos los criterios anteriores encierran lo que susan Kirkpatrick llama un lenguaje que describía la condición de la mujer en términos de cadenas y esclavitud, que había estado en circulación desde mediados de la década de los treinta [del siglo XIX], a través de las corrientes marginales del discurso socialista utópico francés que se puede distinguir en la prensa de Madrid, en Cádiz y en Cataluña (89) .

La actitud de la Avellaneda, desde su adolescencia, muestra que se anticipada totalmente a su época. Esta 
conciencia proyectada de la Avellaneda demuestra que era, indudablemente, una mujer valiente y muy atrevida, a tal punto que expresó sus pasiones con la libertad creadora de los hombres de su tiempo. Una libertad que la llevó incluso a tocar el tema erótico, inimaginable en una mujer de las primeras décadas del siglo XIX. Lo señala Lazo, cuando dice al respecto: "[l]o romántico de la Avellaneda llena y anima su gran poesía, que es la erótica, erotismo que con potente intensidad se vuelca en los poemas a [los] hombres" (51). Un ejemplo es el segundo de sus textos "A él," donde habla de la terminación de una relación amorosa: "No existe lazo ya: todo está roto" $\left(297^{14}\right)$. En este verso, se siente la pasión que hubo y la madurez de la poeta que, a pesar de lo que ha sufrido en la relación, de la soledad en que queda y de acusar al hombre, de "proceder tirano" y de "vengador terrible," le dice también, desde allí, con asombrosa madurez: "Ni amor ni miedo al contemplarte siento" y al final lo perdona generosamente.

El primer poemario de la Avellaneda salió a la luz en 1841; ya la poeta catalana Josefa Massanés (Tarragona, 1811-Barcelona, 1887) había publicado en igual año sus Poesías. Carolina Coronado (Almendralejo, Badajoz, 
1823-Lisboa, 1911) les sigue. Estos libros iniciales, señala Kirkpatrick:

no planteaban explícitamente la cuestión del destino de la mujer aunque [...] sus elaboraciones del sujeto lírico giraban en torno a la posición que ocupa la mujer en el mundo [...] parece que las demás mujeres interpretaron esta primera poesía femenina romántica como expresión de una angustia particularmente femenina y que eso las animó a expresarse ellas mismas; y dado que el número de poetas creció, todas se sintieron más seguras a la hora de expresar abiertamente su dolor y su resentimiento, hasta entonces callados, en un lenguaje con un claro matiz político. (90)

Es precisamente su obra poética la que consagró a la Avellaneda, a pesar de la acogida que se le dio a sus novelas. El primer poema que aparece en las tres ediciones de su Poesías, es el conocido soneto "Al partir." Según la autora, escribió el texto poco antes de dejar el puerto de Santiago de Cuba, en la goleta francesa Bellochamp, rumbo a Burgos, el 9 de abril de 1836. En "Al partir," expone las emociones de ese rompimiento hablándole directamente a su isla: "¡Perla del mar! ¡Estrella de Occidente!/ ¡Hermosa Cuba!" (N. pág.), lo que 
manifiesta su amor patrio. Después expresa sus sentimientos desde el Yo: "cubre el dolor mi triste frente." Kirkpatrick cree que a partir de la segunda estrofa la poeta insiste en tener una actitud pasiva al decir que es arrancada "del nativo suelo" (167). Posteriormente se abandona al destino, característico de la época: "Doquier que el ado's en su furor me impela" (N. pág.) .

No siempre la Avellaneda tomó esta actitud. Se convirtió con el tiempo en una defensora de las posibilidades de la mujer, desde el poema también, con un impulso que la llevó a enfrentarse a su sociedad, lo que puede observarse en muchas de sus composiciones. Hay un romance titulado "Contestando a otro de una señorita," aparecido en la edición de 1850, que, como indica su nombre, es una respuesta, mediante la que conocemos la idea que la joven tiene de la camagüeyana:

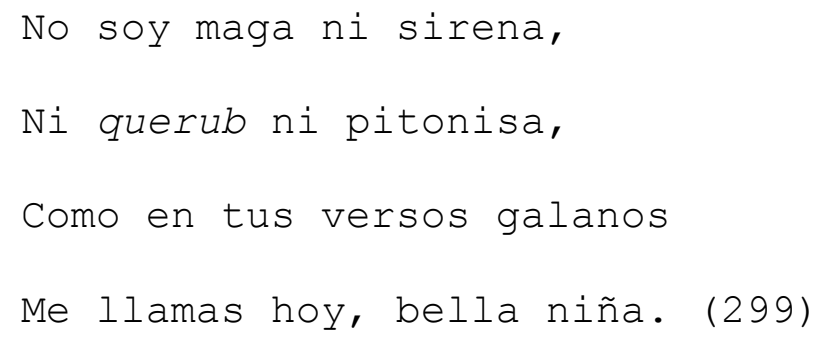

Luego la poeta le dice cuál es su nombre de pila y cómo la nombran la madre y los amigos: Tula. Pide que la llame simplemente "Gertrudis, Tula o amiga." Entonces, a partir del verso 13, señala: 


$$
\begin{aligned}
& \text { Amiga, sí; que aunque tanto, } \\
& \text { Contra tu sexo te indignas, } \\
& \text { Y de maligno lo acusas } \\
& \text { Y de envidioso lo tildas. } \\
& \text { En mí pretendo probarte } \\
& \text { Que hay en almas femeninas, } \\
& \text { Para lo hermoso entusiasmo, } \\
& \text { Para lo bueno justicia. (300) }
\end{aligned}
$$

Hace la Avellaneda una clara reinvidicación de la mujer oponiendo los versos 15-16 con los 19-20. En los primeros utiliza los vocablos «maligno»y «envidioso» que ha empleado quien le escribe, enfrentándolos, mediante dos acciones que, desde el sujeto femenino, van a probar: capacidad de entusiamarse ante lo bello y además, de hacer justicia ante lo bueno. A la luz del siglo XXI no parecería tan adelantado el poema, pero hay que recordar que durante el romanticismo ocurre el comienzo, precisamente con Gómez de Avellaneda, Josefa Massanés y Carolina Coronado, del boom de la lírica femenina en España, que hasta entonces había estado bajo el influjo, fundamentalmente, de las francesas Jorge Sand (Aurora Dupin, baronesa de Dudevant) y Madame de Staël cuyas obras, muy especialmente Corinna, habían ejercido considerable influencia en las hispanas. Fue un período de enfrentamiento a 
un mundo predominantemente masculino. En el caso de la Avellaneda fue Zorrilla quien leyó ante la concurrencia del Liceo de Madrid uno de sus poemas antes de presentarla. Recordemos que era aquélla una sociedad ranciamente religiosa donde la mujer era vista como un ente doméstico que nada tenía que ver con el intelecto.

En otro de sus poemas, "Despedida a la Señora Da. D. G. C. de V., ${ }^{16 "}$ Gómez de Avellaneda reclama a Lola, una amiga poeta, que las abandona. Los dos primeros versos de la composición reflejan el ahinco, con cierto tono masoquista, por todo lo que ha hecho por retenerla en su ciudad: "¿Y nos dejas, cruel? ¿Y nada alcanza/El tierno llanto, el suplicar ferviente?" (277). La Avellaneda, que empieza desde el plural y continúa en la primera persona del singular, compara la labor de una intelectual con la de quien decide dejarlo todo para dedicarse a la vida matrimonial. Se introduce en este texto, además, cierto tinte homoerótico. Dolida, como ya lo ha expresado en los versos anteriores, a partir del quinto expresa ira contra aquél que le aleja al ser femenino con quien la une un gran afecto:

$$
\begin{gathered}
\text { ¿Qué engañosa esperanza, } \\
\text { Presto tal vez deshecha, } \\
\text { Hoy seduce tu pecho, que resiste }
\end{gathered}
$$


A la voz del amor, y el adios triste

Dicta a tu labio, que mi labio estrecha? (278)

Hay aquí una mujer que, besando a otra en los labios, habla de un amor que la seduce "engañosa," y la aleja de su lado. Esa otra persona contra quien habla la Avellaneda es el hombre que se casará con Lola. Sin embargo, lo más importante del poema es que Lola es poeta y va a abandonarlo todo para dedicarse a cumplir con las funciones a que en ese tiempo estaban destinadas las mujeres: la casa:

¡Y tú, que el fuego sacro

Sientes hervir del genio! iTú, que alientas

De elevada ambición el noble brío! ¿Cómo es, cómo es que intentas Hoy destrozar el ara,

Do el alto númen a tus votos pío

Inmarcesible lauro te prepara?

Te llama aquí el destino; aquí la gloria

Con halagüeña faz las puertas te abre De su sublime templo, Y el bello afán que tu ventura labre Será a tu sexo admiración y ejemplo.

¡Sí! ¡Tente! ¡Mira! ¡Toma! ¡Que en tu mano Torne a vibrar la lira 
De la de Lesbos malograda musa! (278)

En esta composición, donde se explica que Lola va a abandonar Madrid y el mundo de la literatura, la Avellaneda compara la vida de una creadora, que es la de ella misma, con la dedicada al hogar, el papel tradicional femenino; hogar al que se marcha Dolores. Luego continúa del mismo modo hasta que empieza a decirle lo que ocurriría si permaneciera en su labor de poeta, y lo hace con tono airado, y hasta recriminatorio, lo cual demuestra el alto concepto que tenía de las intelectuales. En las estrofas que continúan se habla de las dificultades que se asocian con otros creadores además de Safo. Habla de Camoens, de Ovidio, de Cervantes "[p]obre al morir, como lo fue en la cuna" (278). Según Kirkpatrick "la poeta reconoce [aquí] el sufrimiento que acompaña al genio y aconseja a Lola que se vaya de Madrid" (176). Al finalizar el poema, no sin cierto tono sarcástico, expresa la Avellaneda: ¡Huye, triste mujer! Mi ruego loco Desestima prudente: Yo lo condeno ya, yo lo revoco. ¡Vete! [...] . $[\ldots \ldots \ldots \ldots \ldots \ldots \ldots \ldots \ldots \ldots$

Torna a buscar del estimable esposo, Que -en tus patrios jardines- 
De alegre mirto y cándidos jazmines

Tu blanca sien coronará gozoso.

¡Huye no tornes más! ¡Tu hogar tranquilo

Ama, cual ama el náufrago la tabla [...]. (279)

Posteriormente la poeta declara, desde su Yo romántico: "Nunca igual dicha gozaré!" Y habla de su historia en la naturaleza de la isla, al cuidado de la madre cuando "burlando su vigilancia" (279) escribirá "[d]ulces versos de amores" (279). Dice, con melancolía, que no va a morir en cuba y concluye: "Y del puerto distante,/Sin brújula, piloto ni camino,/Navego con los vientos del destino." (279). Destino que es presencia en la poesía del período. Pero a pesar de que aquí se mezclan el amor a la naturaleza y a la patria, lo que resulta más importante es la defensa que hace la Avellaneda de la intelectual por encima de la mujer de familia que por unirse al hombre deja atrás la poesía, lo cual en definitiva era una forma liberalizadora de su estado.

Hemos visto, en el texto anterior, cómo la Avellaneda compara las vicisitudes que enfrenta una mujer que se dedica a la carrera literaria con las de quien decide juntarse al hombre y continuar desempeñando el papel que le ha impuesto la sociedad sexista, donde pasa a un segundo plano, y no el de un ser humano que puede pensar y experimentar sus pasiones. 
Hay otro poema donde equipara al hombre con la mujer, "El porque de la inconstancia," que está dedicado simplemente "A mi amigo..." La composición parece partir de una controversia que se ha tenido con alguien a quien llama simplemente amigo. La primera estrofa dice:

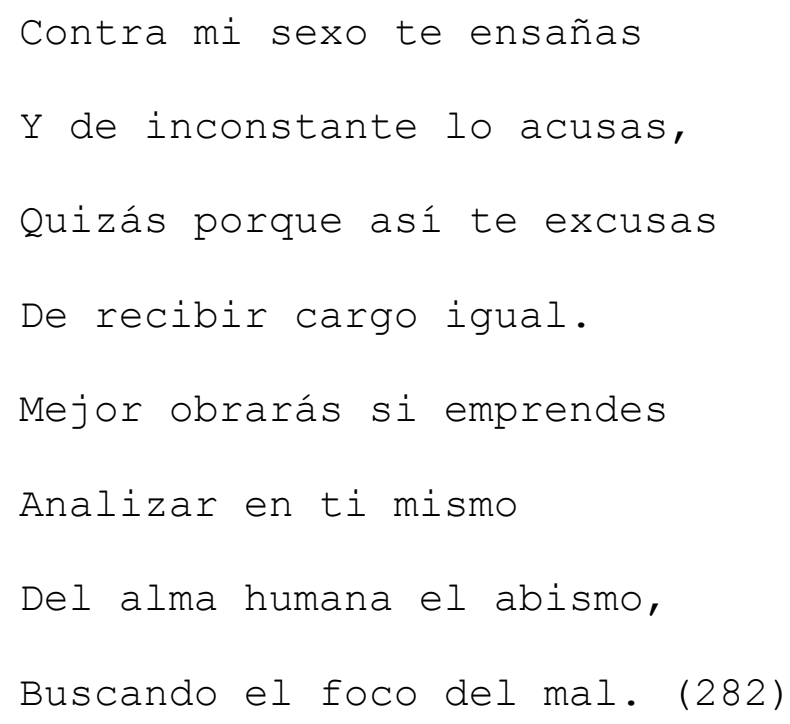
afirma:

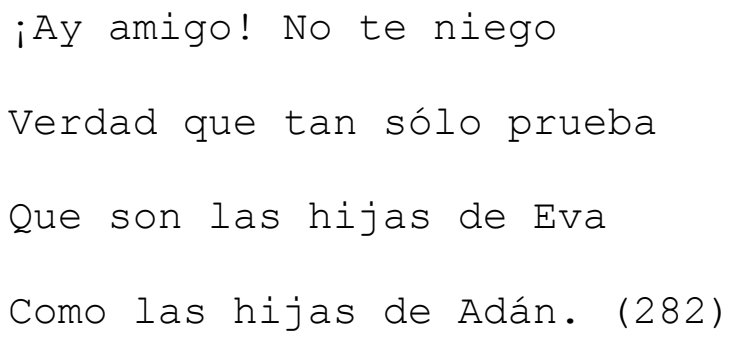

A mediados del siglo XIX, la Avellaneda habla ya de igualdad entre hombre y mujer. Resulta difícil asimilar hoy el 
papel de avanzada que ella tuvo, conociendo que en la época en que se escribe este texto se consideraba que el deseo sexual era una expresión masculina, vedada a la mujer. El final de esta misma estrofa dice que ese deseo es igual en ambos:

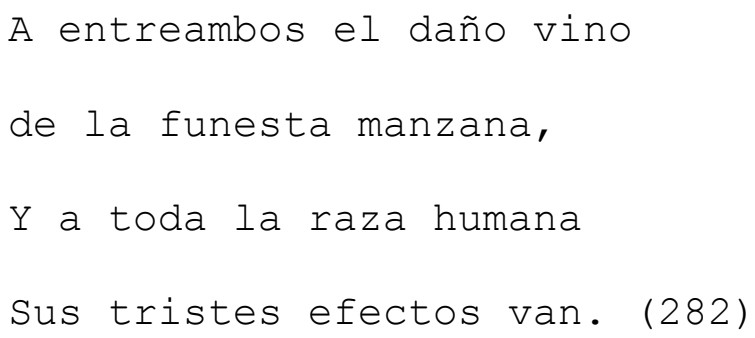

La Avellaneda no contradice, enteramente, el papel de la mujer en la cultura judeocristiana que, desde el primer libro de la Biblia, aparece como la causante de los males del mundo al desobedecer a Dios y comer "del fruto del árbol que est[aba] en el centro del jardín" (Gen. 3.3). Ella inclusive ve la fisiología sexual humana como un hecho pecaminoso pues lo llama "daño" y a la metáfora de la unión carnal la califica de "funesta." Posteriormante, sin embargo, expresa que la mujer es capaz de buscar su libertad, es decir, que está, de hecho, interpretando que vive sin ella: "Y rompe lazos del mundo/Como el águila la red" (282) .

En "A mi jilguero17," poema a un pájaro enjaulado que se niega a cantar en su prisión, Kirpatrick cree encontrar una imagen en forma refleja pues el ave encerrada es la de la autora (184). En este texto el sujeto que escribe se halla 
delante de una jaula "preciosa" donde no falta nada. Puede interpretarse, realmente, como proyección de la mujer del diecinueve, a la que se consideraba "cautiva" dentro de la familia y dedicada solamente a ésta. La poeta se da cuenta que el animal no canta: "¡Mira que ya me enojas/Con tu silencio triste!" (238). En la duodécima estrofa está claramente expresado este tema que después se convierte frecuentemente en una típica alegoría romántica:

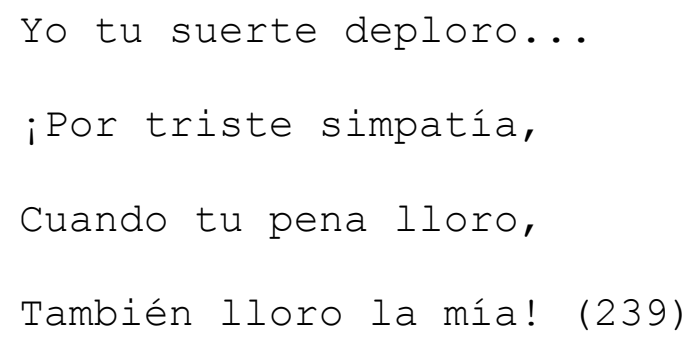

Acertada o no, la interpretación refleja la condición del sujeto femenino. En la estrofa 20 continúa la autora comparándose con el ave:

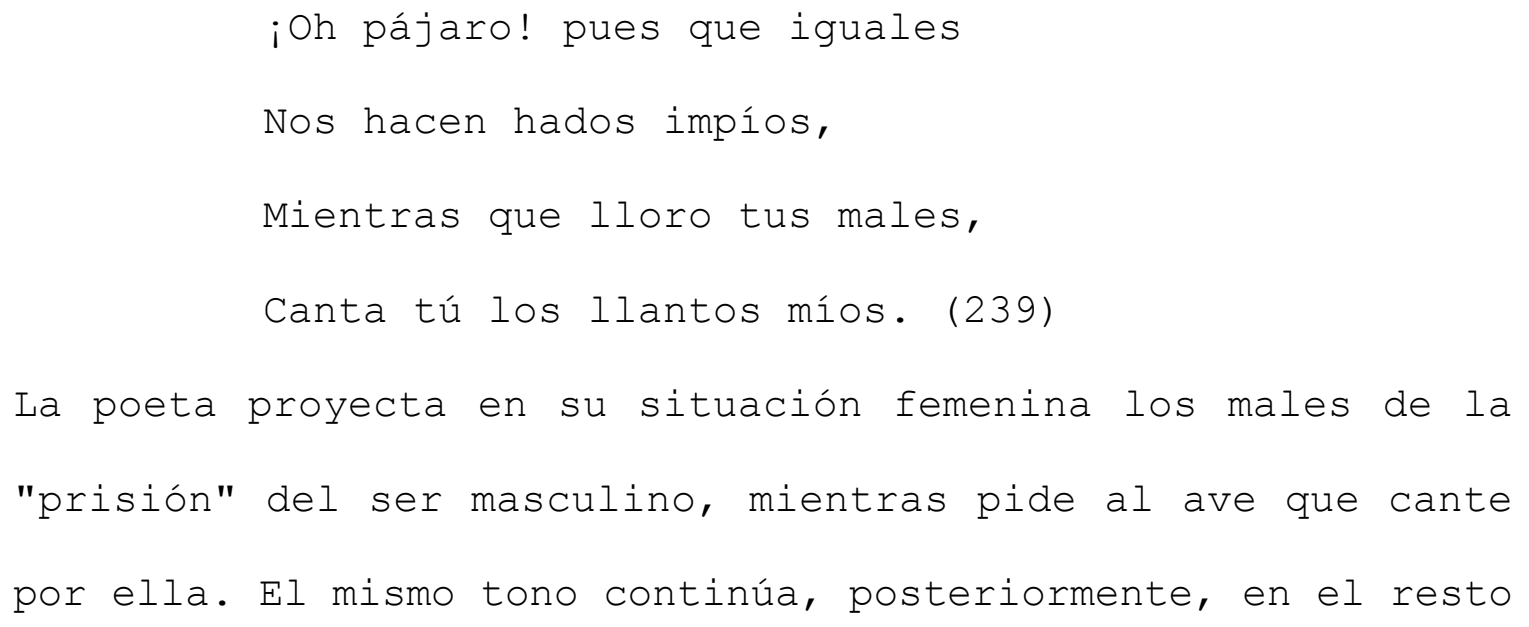


Indudablemente, Gertrudis Gómez de Avellaneda tuvo que sentirse presionada, al escribir del modo liberado que lo hacía, por una definición cultural masculina de lo femenino, tarea nada fácil al estar vigentes aún las estructuras sociales del modelo patriarcal. Dentro de esta perspectiva se enmarca su intento de ser miembro de la Real Academia Española donde no fue elegida únicamente por su condición de mujer. Según José A. Escarpanter, este episodio fue decisivo para su carrera literaria,

pues contribuyó a acrecentar la enemistad que había hacia ella, ya que los partidarios del conde de San Luis, que en un principio eran amigos suyos, al ver que éste no había sido nombrado académico por culpa de las mañas de la Avellaneda, también la combatieron a partir de ese momento. (31)

Es también el período en que, por haberse convertido en la figura "más comentada del ambiente literario madrileño" (Escarpanter 31), aparece en "multitud de sátiras, artículos y poesías en torno suyo, algunas llenas de muy mala intención" (Escarpanter 31), como la que cita este autor:

Yo, doña Safo segunda, entre avellanada y fresca musa que sopla a las nueve 


$$
\text { y hago viento a los poetas. (31) }
$$

Según Zatlin Boring esto sucede porque la "Avellaneda dejó de conformarse al papel tradicional de la mujer y por eso se convirtió en objeto de ridículo" (97). Analiza más adelante las propias confesiones de la poeta donde ésta expone que, en Galicia, los parientes de su padrastro consideraron que "ella no era buena para nada porque no sabía planchar, ni cocinar, ni calcetar; porque no lavaba los cristales, ni hacía las camas, ni barría el cuarto" (cit. en Zatlin 97). Es por eso que la llaman «la Doctora», concluye Zatlin. Tula echaba por el suelo la idea que en aquellos tiempos existía sobre la femeneidad. En su caso, hay que imaginar la reacción, no sólo masculina, de quienes no aprendieron a celebrarla, de los que no concebían la fuerza que afloraba en la obra de aquella que, ya en Cuba, años después, funda para las mujeres el Album Cubano de lo Bueno y de lo Bello, en 1860.

La Avellaneda también usó otros métodos de expresión donde se manifestó de una forma poco femenina -para su época-, escudada en la naturaleza. Esto lo vemos en poemas como "Deseo de Venganza" (266), en el que pide al huracán que le dé su fuerza.

$$
\begin{aligned}
& \text { ¿Ven con tu aliento a enardecer mi mente! } \\
& \text { ¿Que zumbe el rayo y con fragor reviente, }
\end{aligned}
$$


Mientras -cual a hoja seca o flor marchitaTu fuerte soplo al roble precipita! (266)

En una explicación de algunos de los símbolos utilizados en esta estrofa Kirpatrick expresa:

Las imágenes sugieren que esta rabia está relacionada con las injusticias de la situación de la mujer: el sujeto imagina la reducción del roble firme y arraigado, a la condición de una hoja seca mediante la cual [la] Avellaneda trata de representar la vulnerabilidad del sujeto femenino y su falta de autoridad sobre su propio destino. (191) Igual o parecidas emociones se vierten en otros poemas, como en el titulado "La venganza" (276-277), donde, según aclara, se hace una "invocación a los espíritus de la noche ${ }^{18}$." Cito sólo algunos versos de este texto que posee 80, aunque desde el inicio el tono es el mismo:

¡Venid! ¡Venid, espíritus indómitos!

¡De horror y duelo este recinto henchid!...

$[\ldots \ldots \ldots \ldots \ldots \ldots \ldots \ldots \ldots \ldots \ldots \ldots \ldots \ldots \ldots \ldots \ldots \ldots$

¡Venid, venid! Del enemigo bárbaro

Beber anhelo la abundante hiel...

¡No más insomnes velarán mis párpados,

Si a él se los cierra mi furor cruel! 


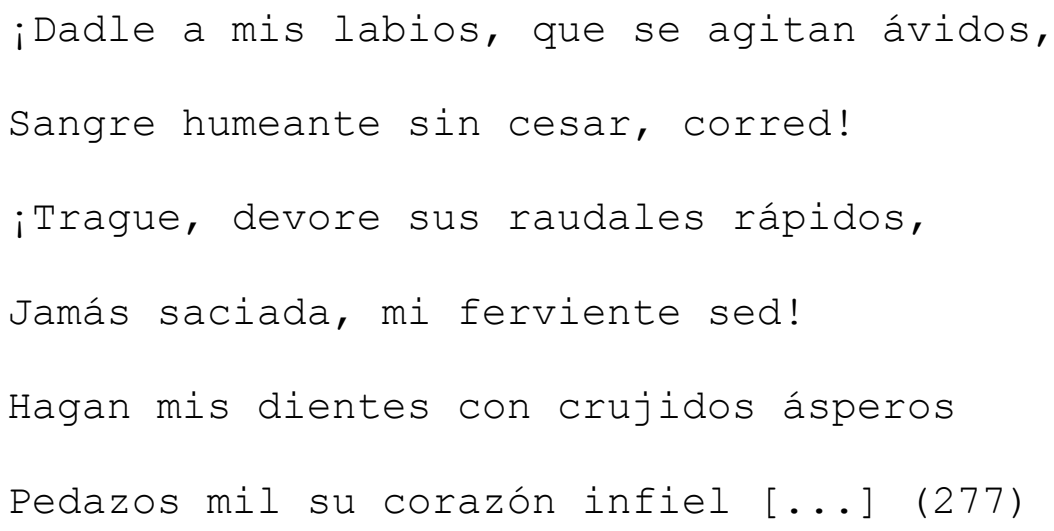

Esta rabia aquí descrita, la fuerza de su impotencia femenina, semeja la de la tormenta que hemos comentado anteriormente. Estas emociones hubiesen resultado muy poco femeninas si las hubiera expresado desde la subjetividad de su Yo, a solas, y no, como lo hace aquí, con la ayuda de "los espíritus de la noche" 0 , en el anterior, de un fenómeno metereológico tropical: son versos que encierran una metáfora de gran fuerza catártica.

Otro poema donde la cólera desborda las fronteras de la subjetividad a tal punto que toma forma apocalíptica es "El día final" (283-284). La diferencia con los citados anteriormente radica en que el hablante es sólo un observador, lo que no impide que hacia la conclusión de la poesía se proyecte su furia. El título se auto-explica: el final de los tiempos. Dios retira su mano de la creación y ésta regresa a la nada de donde la formó. A pesar de la visión apocalíptica, 
la acción aumenta paulatinamente. En las últimas estrofas, donde la anarquía y las fuerzas forman el caos tenemos:

En tanto que la tierra

$[\ldots \ldots \ldots \ldots \ldots \ldots \ldots \ldots \ldots \ldots \ldots$

Vorágines inmensas abre y cierra,

En convulsión se agita,

Y hace que doblen, cual flexibles cañas,

Sus empinadas cumbres las montañas.

$[\ldots \ldots \ldots \ldots \ldots \ldots \ldots \ldots \ldots \ldots \ldots \ldots$

Pues dejando el sol la roja frente

De su centro desata

Volcánico torrente,

Que en pavoroso incendio se dilata.

Interminable trueno

Rueda en aquel ingnífero océano;

Chocan, crujen, se rompen los planetas

-Que en el hirviente seno

Giran como en el mar náufragas naos-,

Crece el incendio, el cielo se desquicia.

Y a una señal de la eternal Justicia

Se hunde la creación y torna el caos! (284)

Al usar la tercera persona, esa fuerza tremenda, terrible, que para la Avellaneda es imposible desatar desde su feminidad, la 
traspasa a la masculinidad de Dios. Sólo así logra su objetivo al borde de la fragmentación y destrucción de ella misma.

Estos modelos de expresión femenina, utilizados por la Avellaneda, tienen una gran importancia, pues fueron usados posteriormente por otras románticas; quienes ocasionalmente, incluso, titularon sus composiciones como las de la Avellaneda. Tal es el caso de Adelaida del Mármol y su texto "A mi jilguero ${ }^{19}$." En otros ejemplos, lo aprovechado fue el modo de enmascararse, en la naturaleza, para dar rienda a una fuerza no concebida como femenina pero posible en aquélla, como había hecho su precursora.

La vida de Gertrudis Gómez de Avellaneda fue difícil. Ya enferma, redactó unas letras ${ }^{20}$, que dan fe de los sentimientos que la sociedad de su época provocó en sus afectos y en su labor creadora. En esta carta, dirigida al "Exmo Sor ${ }^{21}$. Marques de Alcañices," que como única fecha tiene el "22 de abril en esta casa calle S. Marcos No. 18," se solicita "una audiencia de S.M. el Rey." La importancia de este documento, que parece haber sido escrito hacia el final de la vida de la Avellaneda, radica en que señala: "El objeto que al demandar tal honra es muy sencillo. Resuelta á abandonar la poesía [ $\left.{ }^{22}\right]$ ha sido la pasion de mis primeros años juveniles, pero que se asocia mal con los pesares que despues he sufrido, deseo 
tributar mis ultimas producciones á las personas que por deber y sentimiento acato y estimo con mayor respeto." Es decir, que en el manuscrito se vislumbra la renuncia de la Avellaneda a la creación lírica que le había colocado en la cumbre intelectual. Esa renuncia parece haberse madurado en la poeta debido a los ataques y sinsabores que había recibido precisamente por ser figura sobresaliente en la literatura de su tiempo.

2 b. Las narraciones cortas de Gertrudis Gómez de Avellaneda:

Myron I. Lechtblau, al analizar una de las leyendas de la Avellaneda, afirma:

[m] uchas historias de la literatura española no hacen más que citar las leyendas muy brevemente. Apenas unas palabras de Romero-Navarro, de Valbuena Prat, de Del Río, de Hurtado y Palencia. Y las historias de la literatura hispanoamericana también [le] confieren escasa importancia [...] (329) En relación con lo que llamaremos ficciones cortas en prosa, siguiendo la caracterización de Hugh A. Harter, quien las designa "Short Prose Fiction[s]" (160), la Avellaneda fue una de las pocas figuras, de las que estudiaremos, que se dedicó a 
ellas. Harter opina sobre éstas: "In her shorter prose works, she clearly displays her skills as a story-teller" (N. pág.). No obstante, su clasificación resulta difícil. Así tenemos, por ejemplo, que Florinda Álzaga, al citar las principales obras de la Avellaneda, nombra a un cuento, "El gigante de las cien cabezas," -escrito precozmente a la edad de ocho años-, leyenda, y, entre las novelas, menciona: "La Baronesa de Joux ${ }^{23}$." Sin embargo Gastón Baquero al referirse a este texto, en "Gertrudis Gómez de Avellaneda como prosista," dice que lo "consider[a] más que una leyenda una novela." Entonces hace un comentario que parece aclarar el terreno: "A propósito digo que estos deslindes entre la leyenda, la novela corta, el cuento y la novela en sí, son muy difíciles de hacer" (66), y se remonta a Edward Morgan Foster -A Passage to India-, quien decía: "Novela es todo escrito que tenga más de trescientas mil palabras" (cit. en Baquero 66). Este crítico expresa lo difícil que resultaría, sin esta aseveración, describir "dónde el género se divide" (66).

Julio E. Hernández-Miyares, al analizar lo que inicialmente fue pensado como una novela -"Guatimozín"- y concluyó llamándose "Una anécdota en la vida de Cortés," lo denomina relato, a pesar del título (322). María A. Salgado en "El arte de la leyenda en Gertrudis Gómez de Avellaneda," 
defiende que se le llame leyenda basada en una explicación que da Vicente García de Diego en su Antología de leyendas de la literatura universal: "es una tradición fantástica, esencialmente admirativa, generalmente puntualizada en personas, épocas y lugar determinado" (338) y aclara más adelante su porqué -citando al mismo autor-:

la condición de tradición es esencial a la leyenda, y no es propiamente leyenda la narración inventada que tenga todos los demás caracteres típicos de ella si no persiste en la tradición popular. Así la llamada «leyenda literaria»" -continúa- "no merece tal nombre más que cuando ha tomado su tema de la tradición o cuando ha perdido la conciencia de su origen literario y se ha incorporado a la trasmisión oral del pueblo (cit. en Salgado 338).

Poco después Salgado da una explicación de estos textos señalando que:

p]uesto que uno de los requisitos indispensables de las leyendas es que se basen en la tradición popular, debe subrayarse que la Avellaneda sigue este requisito al recoger sus temas de fuentes vivas y dar un subtítulo que aclara la región o el país de que son oriundas. La mayor parte comienza con unas 
palabras introductorias en que la autora nos informa de cómo conoció la historia que va a contar. A continuación toma el hilo de la narración y nos conduce al final, aunque no sin detenerse con frecuencia para hacer comentarios sobre el narrador de cuyos labios escuchó el cuento original. Por medio de esta técnica logra establecer y acentuar el carácter legendario y tradicional de sus narraciones (339-340), (énfasis nuestro).

Se ha señalado este largo párrafo, donde Salgado, quizás para evitar la repetición de un vocablo, se traiciona al ilustrar lo difícil que resulta darles un nombre específico a estos textos cortos. Para complicar más las cosas, digamos que en otro de los que llamaremos cuentos (ficciones cortas en prosa), la misma escritora, en sus Tradiciones, en el párrafo inicial de "Dolores" lo nombra «leyenda» en el primer renglón, «novela» en el sexto y «tradición» en el décimocuarto (85). Mary Cruz, en su prólogo a la edición de Letras Cubanas afirma que "prefiere el concepto tradición" (7) , y agrega, "porque, siendo más general, incluye la leyenda y deja margen para lo que no es propiamente" (7). Todo esto luego de haber dicho al comienzo de su estudio, y en el mismo párrafo: "el título de 
esta selección alude a un tipo específico de relatos" (7), (énfasis nuestro).

En relación con estos trabajos Hugh A. Harter nos explica: "All of the shorter fictional pieces that la Avellaneda wrote may be classified as legends (leyendas) inasmush as they are based on folk traditions that had survided down to the nineteenth century in local oral form. Tula supposedly heard them from guides or from an old man of an area she was visiting" (160). Más adelante agrega Harter: "All belong to the tradition of medieval folk tales" (161) (énfasis nuestro). Sea como sea, por su cortedad, por la rapidez desde el comienzo hasta el final de la narración, se incluirán como cuentos. Estas pequeñas obras de la Avellaneda, que han sido hasta el presente apenas estudiadas, muestran salvo raras excepciones, como es el caso de la titulada "Dolores," un cuidado en la forma y una maestría en la exposición, en el nudo, en su desenlace y en las maneras de lograrlo, que la hacen una excelente cuentista y no sólo de su época. Lo que ocurre en "Dolores," es que la Avellaneda utilizó el relato, sobre todo en su primera parte, para hacer patente su pertenencia a la más rancia nobleza española.

En este estudio lo más importante de la mayoría de estas leyendas, tradiciones, cuentos o relatos, es que hay en ellos 
un común denominador: una otredad que acude en el momento que menos se espera y salta en defensa de la mujer.

El chileno Francisco Bilbao (1823-1865), citado por Beatriz Ruiz-Gaytán de San Vicente en "Gertrudis Gómez de Avellaneda y el pensamiento hispanoamericano de su tiempo", decía al analizar la sociedad latinoamericana de entonces "la mujer está sometida al marido, esclavitud de la esposa... pensamiento encadenado al texto, inteligencia atada al dogma, esclavitud del pensamiento" (cit. en Ruiz Gaytán de San Vicente 53). La mexicana hace un estudio de la obra de la Avellaneda y llega a la conclusión de que la personalidad de la misma se halla "evidente o escondida" en sus escritos. Indudablemente que se encuentra y que, además, se opone a la sociedad de "esclavitud" y de servidumbre al hombre. Es que, como dice Zatlin Boring: la "Avellaneda también fue rebelde y se negó a caer en la trampa del papel femenino esteriotipado de su época" (98). Esa rebeldía que se expresa a través de toda su vida y obra y que ya hemos analizado en la poesía se debe, al decir de Georgina sabat Rivers, a que tuvo "conciencia de la injusticia contra su propio sexo" (100).

"La Baronesa de Joux²4," tradición francesa, -aparecida en El Globo de Madrid en 1844 (Cruz 20) es una historia que se desarrolla cuando el Franco-Condado aún no se había 
incorporado definitivamente a Francia ${ }^{25}$. Harter afirma que "[it] is based on a short poem by a French poet named Demesnay" (161). En el cuento encontramos: "Entonces -cuando la mujer representaba tanto y tan poco; cuando era el numen invocado en los combates y la esclava despreciada en el hogar doméstico; cuando se rompían lanzas para sostener su hermosura y se inventaban cerrojos para asegurar su virtud [...]" (38). En estas líneas, la Avellaneda se remonta a una época antigua para proyectar lo que sigue sucediendo en su tiempo: la mujer es el "objeto" adorado por el macho, aquí "numen invocado" mientras se encerraba en su casa a ocuparse de los hombres. Unos párrafos más adelante la idea vuelve a aparecer al referirse a la protagonista: "Nada podía oponer a la inflexible voluntad de su padre una criatura como Berta, dócil por carácter y educada en la servil sumisión que constituía en aquella época la principal virtud de las mujeres" (39) . Hay que fijar la atención en cómo la Avellaneda utiliza entonces y aquella época (énfasis nuestro), para poder criticar su tiempo desde otro, convirtiendo en diacrónico lo que continúa siendo acrónico. Sabat de Rivers comenta de este texto: "Obviamente, la Avellaneda se servía de sus personajes para protestar de la situación desventajosa de la mujer en todos los tiempos, incluyendo el suyo" (107) . 
"Una anécdota de la vida de Cortés," "tradición sudamericana," escrita en 1845, que la autora tomó de su novela Guatimozín, relata cómo el español elimina al emperador y las relaciones que se desarrollan entre Marina -la Malinche, amante del conquistador de México- y Gualcazintla, la consorte del emperador mexicano. En ella, la Avellaneda deja escapar lo personal, como se puede observar en el siguiente párrafo: Nunca se ejerce impunemente la superioridad del genio; nunca los hombres que dominan a sus semejantes por la sola alteza del pensamiento, logran inspirar aquella sumisión que tributamos sin repugnancia a la excelsitud del nacimiento. Esta rareza se explica muy bien. El uno es un derecho concedido por nosotros mismos; el otro lo dispensa solamente el cielo. En aquel reconocemos nuestra fuerza; en este vemos probada nuestra inferioridad. Obedecemos fácilmente al dueño por nuestras convenciones instituido; pero nos rebelamos contra el que nos impone decreto más alto que la naturaleza $(70)$

Queda claro la manera sutil que utiliza la Avellaneda para expresar su propio pensamiento. Más adelante, en el mismo 
relato encontramos que, ahondando iguales ideas, la Avellaneda afirma:

De ese modo toda vida eminente, de iniciativa vigorosa, viene a ser continuado combate empeñado con la resistencia del orgullo colectivo, inclinado a repeler el avasallador poderío de la personalidad privilegiada. Tal repulsión es en cierta manera -muchas veces al menos- no sólo natural, sino legítima; pero no siempre sostiene noblemente la lucha en defensa de su independencia amenazada la inmensa mayoría vulgar; a ocasiones -realzando a su pesar la superioridad que le asusta- recurre para oponérsele a los medios más villanos e inicuos. (71)

"La velada del helecho o el donativo del diablo," tradición suiza, que según Mary Cruz comenzó a publicarse en el Semanario Pintoresco de Madrid el 10 de junio de $1849^{26}$, y donde al decir de Lichtblau, la "Avellaneda [...] muestra ser un hábil escritor que entiende cómo la técnica narrativa puede ampliar el interés y significación del relato" (333). Es la historia de un amor entre una joven rica, Ida Kéller, y un campesino pobre, Arnoldo Késsman, que termina siendo hijo ilegítimo de una dama noble. Arnoldo ha sido criado por un conde y todos murmuran la posibilidad de que el muchacho sea 
un aristócrata secreto. El codicioso padre de la muchacha quiere para ella un hombre que le aporte bienes. Al final el enamorado acude a una cita para encontrarse con un supuesto diablo que le pide unos documentos que están en manos de quien lo crió. Concluye la obra cuando se descubre, por dichos documentos, que la madre del joven enamorado es la misma que la de un famoso barón, y que éste fue quien se disfrazó de Satanás para el logro de su objetivo: obtener las cartas que comprometían la memoria de la madre de ambos. Ida y Arnoldo finalmente se casan en medio de una idílica epifanía local. Esta narración le fue dicha a la Avellaneda por su hermano Manuel, quien había estado en largo viaje "por casi toda Europa" (85). Bien avanzado en el relato aprovecha la Avellaneda para sugerir su pensamiento crítico contra las estructuras sociales impuestas por la Iglesia Católica que encierra su voz de defensora de la mujer: "[a]unque el fanatismo religioso, creador del funesto tribunal que osó llamarse santo, no se igualase nunca en la Helvecia al que dominó largo tiempo en nuestra infortunada España donde se quemaban mujeres, calificadas de brujas, por volar y otros excesos" (129), (énfasis nuestro). Resulta interesante cómo, en medio del nudo de esta obra, considerada una de las joyas 
narrativas de la autora, la Avellaneda aprovecha para romper el círculo patriarcal e ir en defensa de su género.

"Dolores," (Páginas de una crónica de familia), comienza a editarse, por partes, también en el Semanario Pintoresco de Madrid el 5 de enero de 1851 (Cruz 22). Se remonta al año 1425, en Valladolid, a la corte de don Juan II de Castilla y doña María de Aragón y al bautizo de quien llegaría a ser Enrique IV, llamado el Impotente, cuya sucesión produjo conflictos entre Juana la Beltraneja, e Isabel la Católica. La historia de esta mujer que lleva uno de los nombres de la Avellaneda -María Gertrudis de los Dolores-, muestra a quienes serían unos de los padrinos del niño: "el Adelantado de Castilla, don Diego Gómez de Sandoval, conde de Castro-Xériz [...] y su esposa doña Beatriz de Avellaneda" (144-145), (énfasis nuestro), que son los padres de la protagonista. No vamos a entrar a analizar el posible grado de parentesco con la Avellaneda ${ }^{27}$.

Dolores está enamorada de un bastardo muy cercano al rey, quien hace que éste interceda y lo proponga en matrimonio con la hija de los Gómez de Avellaneda. La joven sabe lo que está ocurriendo y espera un desenlace feliz. El rey quiere casarlos pero la madre se opone y logra, por medio de una enredada trama, separarlos para siempre. Tula aprovecha el momento de 
describir a doña Beatriz, para decir lo siguiente: "Pero a pesar de todo, Dolores no dejaba de comprender que su unión con el que amaba debía encontrar obstáculo en la altivez de su familia, y en especial en la de su madre, cuya alma orgullosa poseía la inflexible firmeza de que en general se juzga desprovisto el bello sexo" (164), (énfasis nuestro). Un poco más adelante agrega: "No desmayó el varonil ánimo de doña Beatriz en momentos tan terribles" (187), (énfasis nuestro). Una vez más, la autora aprovecha su escritura para exponer sus criterios en relación al esteriotipo de época sobre la mujer, amén de que critica la imposición social o familiar -aquí en su contra de parte de la progenitora- en cuanto a quién puede - no amar una mujer, lo que, además, recuerda lo que le aconteció a la autora, aún en Camagüey, durante su juventud. En "La montaña maldita," otra de sus tradiciones suizas, publicación iniciada el 8 de junio de 1851 en el Semanario

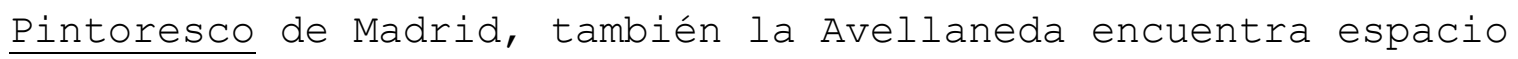
para exponer su pensamiento en defensa de los derechos de la mujer. De esta narración dice Harter: "It is a story that contains little that we associate with Tula's interests, except that she makes the mother a woman who has sinned and been abandoned by her seducer" (162), (énfasis nuestro). 
Como se ha observado hasta ahora, en cada narración la Avellaneda se aprovecha de una u otra forma para expresar sus más íntimos deseos de redención femenina y en "La dama de Amboto," tradición vasca, publicada en 1858, convalida su posición. Es una narración que se remonta a la Edad Media. En ella, a María, única heredera del señor de una ilustre familia que habita un "soberbio castillo," le nace, diez años después y en segundas nupcias del padre, un hermano que por sucesión masculina se convierte en el heredero. Asevera la Avellaneda: "Tal era el espíritu de la época que hablamos: el sexo menos fuerte era desheredado sin piedad, y muchas veces se le condenaba a la perpetua clausura de un monasterio, para que el varonil representante de la casa no tuviera ni aun el cuidado de proporcionarle aceptable colocación o módicos alimentos" (241). María interiormente se rebela contra la situación y comete un fratricidio. Se convierte en la heredera pero no es feliz. Finalmente se suicida en el mismo lugar donde había provocado la muerte del hermano. Este relato fue escrito cinco años después de que la Avellaneda aspirara, y se le negara, la entrada a la Real Academia Española. Cruz, en el prólogo a sus tradiciones, al comentar el nacimiento del hermano que despoja de su mayorazgo a la protagonista, dice: "[p]iénsese en la negativa de los miembros de la Real Academia de la Lengua 
Española a darle entrada a quien como Tula poseía méritos que pocos de ellos podían aducir [...]" (14). Denigrante suceso que Harter describe de este modo:

When she applied for admittance to the prestigious Royal Academy on the death of her friend Juan Nicasio Gallego, she was denied entry on the ground that she was a woman. A subsequent polling of the members of the Academy showed conclusively that la Avellaneda was considered by them to be eminently deserving of election to the vacant seat by virtue of her literary achivements. Her exclusion was decided solely on the basis of her sex. (18)

Hay que pensar cuánta impotencia sentiría esta mujer, consciente de que poseía una inteligencia que la situó por encima de los escritores y de la sociedad de su época, tras la experiencia de esta derrota por el único hecho de su sexo. Sabat de Rivers expresa que en estos cuentos, refiriéndose a "La dama de Amboto" y a "La Baronesa de Joux," es: "[d] onde a nuestro ver se expone más vigorosamente esta protesta de los abusos contra el sexo femenino" (107).

Otras ficciones cortas en prosa de la Avellaneda son: "La Bella Toda," de 1858, tradición vasca; "Los doce jabalíes," también vasca; "La ondina del lago azul," de 1859, pirenaica; 
"La flor del ángel," de 1859, vasca; "El aura blanca," de 1860, cubana, y "El cacique de Turmequé," posiblemente escrita en 1861, sudamericana.

Además de las luchas de la Avellaneda por el papel de la mujer en la sociedad que continuamente surgen en su obra, hay que mencionar la perfección de estas narraciones que se hallan entre las mejores no sólo de su época. Emilio Cotarelo y Mori, citado por María A. Salgado enuncia, por ejemplo, de "La ondina del lago azul," que "[e]s una magnífica leyenda que parece escrita por Walter Scott, tan alada y vaporosa y a la vez tan interesante nos la ofrece la autora. No tiene nada de original [...]. Pero ni Puchskin en su Rusalka, ni Hoffman, igualan a nuestra escritora en esta preciosa leyenda" (cit. en Salgado 344). Esta ensayista señala que: "las leyendas de la Avellaneda merecen mayor difusión de la que hasta ahora han tenido ya que [...] muestran una de las facetas menos conocidas de la autora" (346).

A las menciones directas de la Avellaneda en defensa de la mujer, se une la voz de Rosario Rexach, quien refiriéndose a la lucha romántica de la creadora por los marginados -el bandido, la aventurera, el proscripto y el esclavo, entre otros- dice: "Y también a la mujer, que ella considera otra esclava" (55). Y más adelante cita una aseveración hecha por 
la intelectual dominicana Camila Henríquez Ureña: «Gertrudis Gómez de Avellaneda fue una gran rebelde, emancipada de muchos prejuicios, una de las primeras feministas del mundo en el orden del tiempo» (cit. en Rexach 55).

Baste, para concluir, unas palabras de la misma Gertrudis Gómez de Avellaneda, que cita Florinda Álzaga tomadas de los ensayos que publicara bajo el título de "La mujer" en su habanero Album cubano de lo bueno y de lo bello y donde se refiere a la historia de los aportes de la mujer a la ciencia: Si la mujer -a pesar de estos y otros brillantes indicios de su capacidad científica- aún sigue proscrita del templo de los conocimientos profundos, no se crea tampoco que data de muchos siglos su aceptación en el campo literario y artístico: iah! ¡no! también ese terreno le ha sido disputado palmo a palmo por el exclusivismo varonil, y aún hoy día se la mira en él como intrusa y usurpadora, tratándosela, en consecuencia, con cierta ojeriza y desconfianza, que se echa de ver en el alejamiento en que se le mantiene de las academias barbudas. (226)

Y las palabras de Alberto Rocasolano, quien en Poetisas cubanas, concluye con que la Avellaneda es "la figura 
literaria femenina más completa que ha dado Cuba" (22). Lezama Lima afirma, no obstante, "[c]omo las obras de muchos de sus contemporáneos, el tiempo ha dejado con vida poca de sus producciones, que ofrezcan una atracción para la posteridad" $(2: 73)$

\section{María de las Mercedes Valdés Mendoza.}

Manuela Herrera de Herrera, en sus Escritoras Cubanas de 1893, señala que nació en Matanzas lugar que también consignan Calcagno y González Curquejo. Recientemente, en 1985, Rocasolano sitúa su lugar de nacimiento en Guanabacoa, -sitio que también aparece en el Diccionario de la Literatura Cubana, de 1984 (II: 1066)-, el 11 de noviembre de 1820, y agrega que "[f]alleció en su pueblo natal el $1^{\circ}$ de junio de 1896" (41). Domitila García de Coronado, sin embargo, refiere que su nacimiento ocurrió en septiembre de 1822 (N. pág.) •

Según Rocasolano los propios padres de la poeta le impartieron una esmerada educación. A temprana edad leyó a clásicos y románticos y comenzó a escribir versos. El letrado Francisco Javier Foxá la dio a conocer en las tertulias de Nicolás Azcárate. En el Diccionario de Literatura Cubana se aclara que su vida retirada la hubiese hecho pasar inadvertida si este intelectual no la hubiera leído en tales reuniones sin 
que ella lo supiera (II: 1065). García de Coronado cuenta cómo éste, quien había ido al bufete de Francisco Valdés Mendoza, hermano de la poeta, mientras esperaba la llegada de aquél oyó a Mercedes recitando en la sala inmediata una de sus poesías. Al preguntarle más tarde al hermano, supo que los versos no eran de poeta varón sino de una autora desconocida a la que pidió algunos originales que, sin su permiso, leyó a otros intelectuales, y quienes "la reconocieron como un genio superior" (García 40). El poema que Foxá escuchó de la autora era "La rosa blanca."

Mercedes Valdés Mendoza se halla en el tomo primero de las Noches literarias de Azcárate, con dos poemas: "Canto del Penitente," y "A una amiga." A partir de aquí sus textos aparecieron en las principales publicaciones de la época incluyendo los periódicos madrileños y sevillanos. Herrera de Herrera expresa que colaboró en Cuba Literaria y en la Revista Habanera (N. pág.). Lo hizo también en Album cubano de lo bueno y de lo bello, El Liceo de La Habana, Guirnalda Cubana, El Rocío, Faro Industrial de La Habana, Floresta Cubana, El Aguinaldo y Revista de La Habana. Figura en varias antologías, entre ellas Cuba poética, de Luaces y Fornaris; Poetisas $\underline{\text { americanas, }}$ de José Domingo Cortés; Album Poético Fotográfico de Escritoras y Poetisas Cubanas de Domitila García; las Cien 
mejores poesías cubanas, de José María Chacón y Calvo; Florilegio de Escritoras Cubanas de Antonio González Curquejo; así como en la recopilación hecha por Manuela Herrera de Herrera en sus Escritoras cubanas de 1893.

En 1847 publicó Cantos perdidos, con un prólogo de Ramón Jiménez de León, libro que Rocasolano juzga "de escasísimo valor" (41) y, en 1854, Poesías, cuya prólogo es de Ramón Zambrana, quien "destaca «la elevación de los pensamientos y la elegancia en la versificación» presentes en [sus] poemas" (cit. en Rocasolano 41) y también: "Su nombre ya tan popular y tan querido lo guardará Cuba con orgullo y en lo venidero brillará sin duda a la par de nuestra ilustre Avellaneda" (cit. en González Curquejo II: 61). Es de notar con quien la compara en su momento el esposo de Luisa Pérez de Zambrana. Este poemario, según el mismo Rocasolano, posee "algunos poemas discretos y aceptables" (41). García de Coronado afirma que quienes recopilaron el tomo de poesía fueron dos intelectuales de renombre: Antonio Bachiller y Morales y Rafael María de Mendive. Y Herrera comenta que "[e]ntre sus más celebradas producciones cuéntanse las odas A Colón y Al Mar" (267); el primero de los cuales, según varios autores, fue traducido al inglés y al alemán. 
En su poesía se observa la melancolía aunque con la confianza de una felicidad futura. Así lo expresa en "La esperanza," antologada por Rocasolano en Poetisas Cubanas (42-45), cuando, personificándola, le implora que lance su luz sobre ella, en versos donde sutilmente muestra, además, la búsqueda de la gloria, algo que, en su época correspondía al varón. El poema consta de 12 octavas reales que dan una idea de su conocimiento de la métrica y de la rima. La primera estrofa se repite nuevamente en la novena:

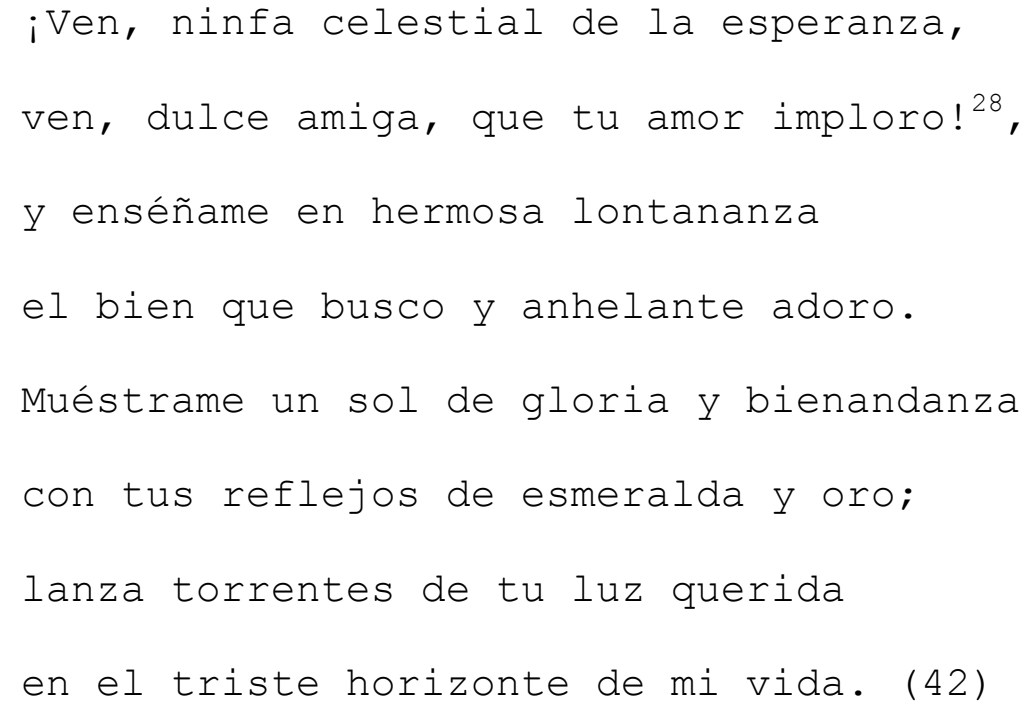

Más adelante, en la misma composición, en la sexta estrofa, indirectamente se compara con un guerrero-medio utilizado por la mujer de esta etapa para expresar una fuerza que solamente se aceptaba en el hombre como vimos ya en la Avellaneda:

Lanza un grito de muerte en la batalla

el arrojado, intrépido guerrero, 


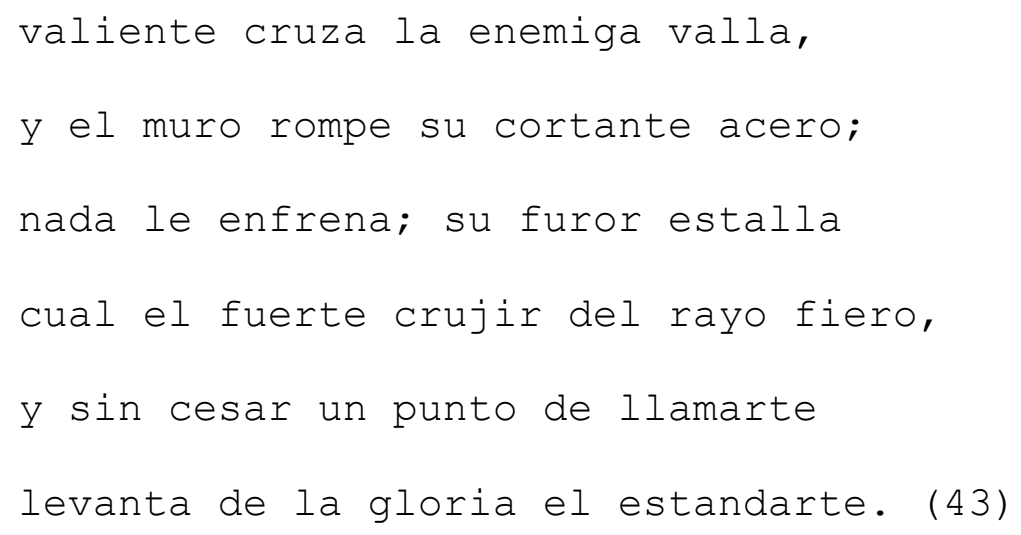

El tema del marginado, donde vuelve a "vestirse" de varón para expresar sus emociones, está presente en "Canto del penitente," texto antologado por Azcárate, donde sobresale una fuerza poco común en la poesía femenina de su tiempo que ella enmascara en boca de un hombre:

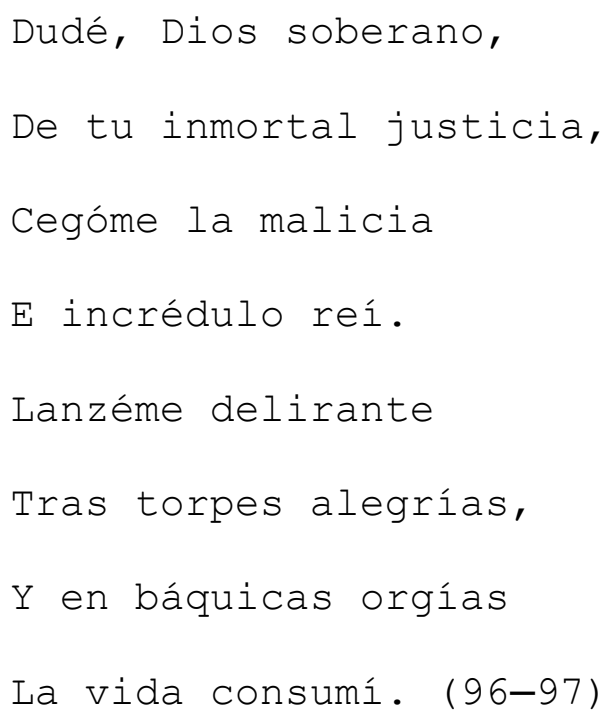

Esta composición trata de un hombre que hacia el final de sus días encuentra la fe. No faltan en ella los motivos fúnebres característicos del período:

Los años han vestido 
De nieves mis cabellos,

Y ya no brilla en ellos

La ardiente juventud.

Se extingue de mi vida

La animadora fuente,

Y acercóme doliente

Al mísero ataud. (102)

Estos motivos fúnebres, junto a la religiosidad, el canto filial y a la amistad, así como, nuevamente el iterado tema de la pretensión de la gloria, se ven en "A mi amiga," largo poema de 120 versos publicado, también, por Azcárate:

Y no encontrando á mi dolor consuelo, ¿Cómo podré de la enlutada lira

El silencio romper? ¡Dios soberano!

$[\ldots \ldots \ldots \ldots \ldots \ldots \ldots \ldots \ldots \ldots \ldots \ldots \ldots \ldots$

¡Murió mi madre al fin! recuerdo triste

Que nunca el tiempo de la mente borra,

Recuerdo que consume mi memoria.

¿Por qué con ella a la morada oscura

De su sepulcro humilde y solitario

No descendí también? ¡Cuánto tormento

Y punzante dolor me hubiera ahorrado!

¡Y mi padre después...! ¡Desgracia horrible! 
$[\ldots \ldots \ldots \ldots \ldots \ldots \ldots \ldots \ldots \ldots \ldots \ldots$

Llegaron tentadoras ilusiones

A susurrar en torno de mi oído;

Una, exclamaba con acento grato,-

"Me llamo Gloria, y mi laurel te brindo," (108)

La preocupación por el paso del tiempo, así como del valor de esta gloria que buscaba, se nota en un filosófico poema "A mi lira," que antologó Domitila García, algunos de cuyos versos dicen:

$$
\begin{aligned}
& \text { Páginas portentosas de la historia, } \\
& \text { Enardecidos lauros de la fama, } \\
& \text { ¿Qué sois en la existencia transitoria } \\
& \text { Sino el breve lucir de raudal llama? (45) }
\end{aligned}
$$

"La Rosa Blanca," es un poema que llama la atención por haber sido publicado unos cuarenta años antes del conocido trabajo de José Martí, con igual nombre, que vio la luz en Nueva York en 1891. Mercedes Valdés Mendoza era una autora leída por Martí; lo demuestran los comentarios que hizo sobre ella. Pero nada tiene que ver la temática de un texto con el otro. El de Mercedes, recopilado por González Curquejo en su Florilegio de Escritoras Cubanas (II: 63-64), tiene un carácter admonitorio. Una rosa "cándida, pura y hermosa;/bella 
como un querubín" es seducida por el "céfiro enamorado." Éste le dice a la flor:

"Amarte siempre constante,

"Será mi encanto y ventura;

"Yo te ofrezco una alma pura

"Y no olvidarte jamás." (63)

Finalmente la flor cede ante el viento: "Sus pétalos abrió, y él delirante/Libó la miel que incauta le ofrecía" (64). Así concluye el poema:

$$
\begin{aligned}
& \text { Mas, iay!, después la rosa infortunada } \\
& \text { Perdió infeliz su aroma y su frescura, } \\
& \text { Y al rigor de la negra desventura } \\
& \text { Miró su gloria convertida en nada. }
\end{aligned}
$$

Céfiro suave, grato y apacible, Es del amor la dulce primavera; Pero ¡ay!, iperece el corazón sensible Que oye su voz falaz y lisonjera!

Vírgenes bellas de la patria mía, Tomad ejemplo de la pobre rosa; Antes dormir entre la tumba fría, Que olvidar la virtud santa y hermosa. (64) 
Durante la composición se han pintado solamente las virtudes físicas y el mantenerse virgen, a toda costa, como lo más valioso de la mujer. Es decir la visión patriarcal de la época. Sin embargo, no deja de llamar la atención la forma tan sutil que utiliza Valdés para expresar el tema erótico.

En el poema "A Cristobal Colón," escogido también por González Curquejo en Florilegio de Escritoras Cubanas (II: 65-70), tan celebrado en su tiempo, podemos encontrar ciertas imágenes proyectivas, donde se observa, nuevamente, la necesidad de revestir su canto de varón para expresarse. Está la gloria, que, como hemos visto, ella deseaba y que le era tan difícil de alcanzar por el hecho de ser mujer. Nótese, además, el carácter antireligioso de ciertos versos aunque no llegan al ateísmo, típico a veces del movimiento romántico; así como la intensa subjetividad que se compenetra con el momento de la historia; la vehemencia; la imaginación en la reconstrucción del período medival-renacentista, el ritmo y la blasfemia. Este texto canta también a la naturaleza americana y en él se describe la vida del genovés desde su nacimiento. Consta de 23 octavas reales. La 11 y la 12 poseen tanta fuerza que en ellas Valdés Mendoza se iguala a los mejores cantores de su tiempo; y son posibles, a pesar de su fortaleza y de su ímpetu, entonces patrimonio del hombre, en manos de lo que se 
consideraba debía ser lo femenino, por el tema tratado. En estas estrofas se describe lo que sucede en las tierras recién descubiertas y en el ánimo del conquistador debido a las consecuencias de tal encuentro:

El averno tembló. Furias horribles

De los oscuros antros se lanzaron,

Y blasfemias odiosas y terribles

De sus inmundas bocas vomitaron;

Tremendas, palpitantes, irascibles,

Al héroe de los héroes execraron,

Y unidas maldijeron su victoria,

Y la fama inmortal de su alta gloria.

Allí lloró la negra idolatría

Contemplando su imperio destrozado,

Y un espantoso grito de agonía

Arrojó de su pecho lacerado.

Allí la envidia detestable y fría,

Con el rostro de crímenes manchado,

En el oscuro centro del abismo

El triunfo detestó del cristianismo. (67)

González Curquejo también antologó sus "Pensamientos," dedicados «A Rafael María de Mendive,» el antiguo profesor de 
José Martí, que recuerdan la posterior poesía martiana. ¿Sería esta mujer una de las fuentes inspiradoras del modernista cubano? El tema debe ser objeto de otro estudio, pero no podemos obviar la coincidencia también de "La rosa blanca," ya expresada, del comentario de ella que hiciera el famoso cubano y de la popularidad alcanzada por Mercedes:

Venga a mi mano la vibrante lira

Engalanada de vistosas flores,

Y al ardiente entusiasmo que me inspira

Huyan de mí pesares y dolores.

$[\ldots \ldots \ldots \ldots \ldots \ldots \ldots \ldots \ldots$

Mirad el vasto mar grave y sonoro

Mil palacios de espuma levantando,

En bellísimos círculos de oro,

Sus admirables aguas encerrando.

$[\ldots \ldots \ldots \ldots \ldots \ldots \ldots \ldots \ldots \ldots \ldots \ldots$

Por eso el corazón absorto mira

Tanta pompa lucir, belleza tanta,

Y de entusiasmo y de placer suspira,

Y de entusiasmo palpitando canta. (74-76)

Mercedes Valdés Mendoza fue una de las cuatro mujeres presentes en las célebres tertulias literarias que, en 1865, organizó en La Habana Nicolás Azcárate, a donde asistía 
también Mendive. Dada la relación de José Martí, que entonces contaba 12 años, con su admirado profesor, es obvio pensar que estos "Pensamientos," dedicados precisamente a él, cayeran en las manos del futuro poeta, pues, es el 1865, casualmente, el año cuando el padre de Martí lo matriculó en el colegio de Mendive ${ }^{29}$.

Max Henríquez Ureña la valora como "una poetisa modesta que cultivó lo mismo la oda altisonante ( $A$ Colón) que la estrofa sentimental (La esperanza [que criticamos], La rosa blanca), pero su poesía no es de gran vuelo. Su soneto $A$ Scévola suele figurar en las antologías" (I: 277). Sin embargo, sus composiciones han sido consideradas de manera muy diferente por Juan J. Remos, quien estima que es una "[p]oetisa que debe salvarse del olvido" (II: 365). Remos agrega que en su tiempo sus poemas fueron saludados, "con juicios favorables," por Rafael María de Mendive y Bachiller y Morales; no obstante cree que "su técnica [...] se resiente a veces de ser exageradamente altisonante y oscurecer un tanto el pensamiento" (II: 365). José Martí en su ensayo "Tres libros. Poetisas americanas" -aparecida en la Revista Universal, de México, el 28 de agosto de 1875-, comentando la recopilación de José Domingo Cortés, hecha en el París de 
1875, dijo que esta autora era "la de versos fáciles y llenos" (138) .

Todos los temas señalados anteriormente, propios del período romántico, se encuentran en ella, pero ni en uno de sus textos, al menos de los que se han podido revisar, hay asomo de lucha por la emancipación de la mujer. Los libros publicados por Mercedes Valdés Mendoza son hoy inaccesibles. Sólo pueden leerse algunos de sus poemas en las antologías antes citadas.

\section{Luisa Molina ${ }^{30}$}

También mencionada por Gatell, vio la luz en una finca cercana al río Moreto, provincia de Matanzas, el 21 de julio de 1821. Aunque González Curquejo expresa que "nació por el año 1826" (II: 319). Murió en Sabanilla del Encomendador, en la misma provincia, el 20 de abril de 1887. El 24 de mayo de 1857 en La América, de Madrid, se publicó un artículo de Gertrudis Gómez de Avellaneda, cuyo título es, precisamente, "Luisa Molina," y donde se refería a esta poeta matancera. Allí la camagüeyana decía "el nombre desconocido que encabeza estas líneas" (365), para hablar del nombre que había llegado hasta aquellas "áridas orillas del lejano Manzanares" (370). 
Los pocos autores que citan a Luisa Molina, siempre señalan el hecho de que se trataba de una persona rústica a quien González Curquejo llamó "guajira" (II: 319), para que se comprendiera la grandeza de esta mujer que por sí misma aprendió a leer y a escribir, aunque Rocasolano señala que esto le fue enseñado por la madre. Sea como fuere, no deja de impresionar el interés de esta campesina pobre cuyos ecos llegaron a oírse hasta en España. Posteriormente le sirvieron como "únicos modelos literarios" (Rocasolano 48) algunas obras entre las que nombra "el Tesoro de autores españoles, de Quintana; las poesías de Zorrilla, de Martínez de la Rosa y de Milanés; y algunos poemas de Heredia, [de] Plácido y [de] la Avellaneda" (48), (énfasis en el original). A pesar de sus escasas lecturas no tardó en atraer la atención de los círculos literarios de Matanzas y de La Habana, y llegar a oídos de la Avellaneda. Se dio a conocer en la revista El Artista, en 1884, y publicó luego en El Almendares, La Piragua, Brisas de Cuba, El Yumurí de Matanzas, Revista de La Habana, y El Archivo, entre otras. Figura en diferentes antologías: Cuba poética, de Luaces y Fornaris; Poetisas americanas y América poética, de José Domingo Cortés. Rocasolano también nos informa que José Manuel Carbonell, en La poesía lírica de Cuba, tomo III, incluyó una breve muestra 
de la poetisa. Ignacio María Acosta y Emilio Blanchet editaron el Aguinaldo de Luisa Molina, colección de prosas y versos de varios amigos, impresa con la intención de aliviar la miseria que atravesaban Luisa y su familia.

Alberto Rocasolano comenta que "Luisa es un caso típico de poeta natural, ya que ni siquiera cursó formalmente la enseñanza primaria. Dotada de una fina sensibilidad, también se interesó por la Pintura" (48). Hay que tener en cuenta que Gertrudis Gómez de Avellaneda, fuera de Cuba, le dedicó el único ensayo que escribió sobre un poeta de la isla. Y si esto sucedió, fue porque su voz poética la impulsó hasta la capital de la metrópoli. "Dedicamos los cortos renglones," dijo la Avellaneda en su trabajo, "a una existencia oscura, ignorada, humilde, y que, sin embargo, no nos parece menos interesante que la más bella creación de los novelistas, ni menos digna de simpatía que la celebridad más pura" (365). Refiriéndose a la creadora inculta, que vivía muy pobremente en una choza en medio de los campos, pero a quien compara con la heroína francesa afirmó: "Luisa es poeta, como fue héroe Juana." Y continúa:

Luisa es poeta, a pesar suyo; a pesar de una vida de trabajos y de privaciones; a pesar de la soledad del alma, que ha cubierto con un velo de tristeza las 
juveniles inspiraciones de su tropical fantasía.

Luisa es poeta, y lo prueba sin pretenderlo, cuando sola y desconocida, sin ambición ni esperanza, le cuenta a las brisas de los bosques en el silencio de la tarde, el hondo desaliento de su genio. (366)

Luego cita unos versos de la poeta, donde sobresale la melancolía que, aunque muy romántica, rodeaba realmente su vida:

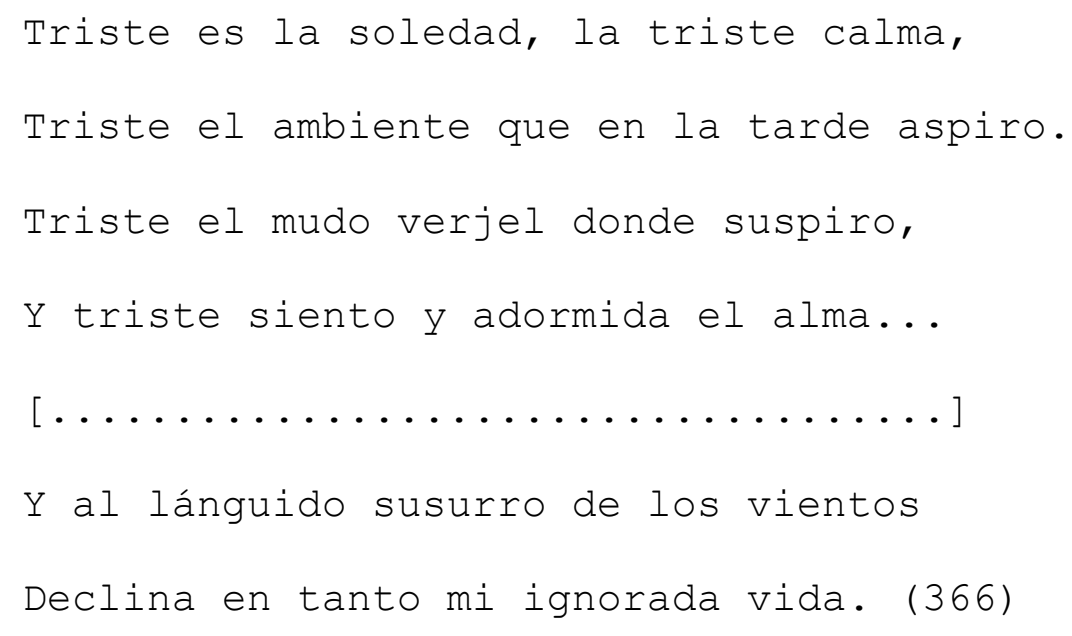

Gertrudis Gómez de Avellaneda transcribió parte de una carta que Luisa Molina escribió a un amigo donde se muestra el deseo que sentía de cultivarse. Leemos allí: "espero merecerle un favor, y es que tenga la bondad de buscarme una obra de filosofía, que yo le cuidaré con todo el esmero posible; de modo que $V$. no tiene peligro en prestármela. Si encuentro en esa ciencia lo que deseo, a V. mismo le daré la molestia de encargar otro libro igual para mí..." (cit. en Gómez de 
Avellaneda 368). La carta demuestra su vehemente deseo de educarse, tan poco afín a su época, y, aun peor, en su caso por ser campesina.

Tal fue la resonancia de sus versos que afirma González Curquejo que "[n]oticiosos algunos literatos de su sorprendente facilidad, hicieron una suscripción en su favor y para que lograse instruirse y mejorara su aflictiva situación de pobreza" (II: 319).

En los textos estudiados de Luisa Molina, hay la búsqueda de un afecto que no puede alcanzar, a tal punto que en "Amor ideal" exclama: "Él no existe, iay de mí!, sobre la tierra," uno de sus sonetos donde también se refleja su gusto por la pintura:

$$
\begin{aligned}
& \text { ilmposible! No puede su dulzura } \\
& \text { retratar mi pincel, ni hallo colores } \\
& \text { que coloren y adornen mis amores } \\
& \text { ni contornos que pinten su figura. (Rocasolano 49) }
\end{aligned}
$$

En otros versos se vislumbra una gran soledad que proyecta en la naturaleza con la que se compara. En "El árbol seco" lo observamos:

$$
\begin{aligned}
& \text { A su tronco desnudo reclinada, } \\
& \text { comparando a su vida mi existir, } \\
& \text { mi alma triste, marchita y desolada, }
\end{aligned}
$$


compadeció su estéril porvenir.

$[\ldots \ldots \ldots \ldots \ldots \ldots \ldots \ldots \ldots \ldots \ldots \ldots \ldots \ldots$

¿Tú brotaste esas hojas, por ventura,

y esa flor sonrosada con desdén,

porque a ti me comparo en mi amargura

y en ti reclino mi agitada sien? (Rocasolano 49-52)

A pesar de su autodidactismo llegó a tener gran dominio de la métrica. Cultivó el soneto y, entre otros, la décima. Una de estas úlimas, precisamente titulada "Décimas," recopilada por González Curquejo, resulta ser autobiográfica. Representa un canto a la naturaleza patria y en ella se despliega la melancolía; puede observarse, además, la queja por la situación en la que se encontraba. Cito las dos primeras estrofas:

\author{
Es Canímar un lugar \\ Triste, solo y miserable, \\ En el cual vivir no es dable \\ Sin trabajos o pesar: \\ Allí, en continuo anhelar \\ Una familia indigente, \\ En una choza inclemente \\ Habita hoy, desamparada, \\ Y su suerte desdichada
}


Lamenta triste y doliente.

A la margen de Moreto,

Tortuoso y oculto río,

Que peñascoso y sombrío

Presenta salvaje aspecto;

Allí el divino decreto

Les impuso amargas penas,

Y en sus márgenes amenas

Su desdicha están gimiendo,

Tristes lágrimas vertiendo

En sus corrientes serenas. (321)

"El Céfiro," es un texto donde demuestra que, no obstante la miseria en que vivió, supo meditar sobre la belleza campestre que la rodeaba y manifestar lo bello de su contemplación, amén de que sus versos expresan la pintura que esta poeta silvestre también cultivaba:

Cuando se alfombran los feraces prados

Con matices de flores purpurinas,

Rojas, blancas, azules y moradas;

Revestidas de árboles copados

Aparecen las cumbres y colinas

Y los fértiles valles y cañadas; 
Con tus alas rosadas,

En la verde arroyada, circuída

De enredadera hojosa y florecida,

Vagas pausado con rumor sereno,

Puro apacible y de fragancia lleno. (González 324)

En los versos de Luisa Molina hallamos la naturaleza, sus desgracias y la melancolía, más que la erudición. Su "poesía es fresca como todo cuanto la rodeó durante su vida, de rica imaginación y arrobadores acentos" (127) como la describe Juan J. Remos en Proceso Histórico, y de "una dulzura cautivadora" $\left(364^{31}\right)$. Martí, quien dejó muestra de su existencia al hacer los comentarios críticos en Tres libros. Poetisas americanas, dijo de ella: "Luisa Molina, de poesía doliente y meditabunda" (138). Todo lo anterior crece en ella, pero, en los versos que han llegado hasta nuestros días no hallamos manifestaciones en defensa de la situación de la mujer. 
Capítulo II. Segundo Romanticismo

\section{1. Úrsula Céspedes de Escanaverino.}

Nació en la hacienda "La soledad"," en Bayamo33, el 21 de octubre de 1832. Murió en Santa Isabel de las Lajas, Las Villas, el 2 de noviembre de 1874, "donde a (sic) suscripción popular se costeó una lápida de mármol para colocar sobre su sepulcro" (González Curquejo 1: 97). Empleó varios seudónimos: La Calandria, escogido por Carlos Manuel de Céspedes; La Serrana, según el prólogo a sus poemas de Juan J. Remos (9); así como el de Carlos Enrique Alba.

Como "una de las poetisas más apreciables de su tiempo" (7) la describe Juan J. Remos en "Ursula Céspedes de Escanaverino," que hace de prólogo a sus Poesías publicadas en 1948. Muchos años antes, José Martí, en su ensayo "Tres libros. Poetisas americanas," la había descrito como "ora valiente y correcta, ora desaliñada y quejumbrosa" (138) . Lo cierto es que Úrsula Céspedes perteneció, agrega Remos, a "una ilustre familia bayamesa, originaria en los primeros tiempos de la conquista de la Isla, y entre cuyos vástagos más significativos descuella [...] [Carlos Manuel de Céspedes]" (7) .

Hizo los estudios primarios en casa y aprendió posteriormente música y francés, según Rocasolano. González 
Curquejo añade: "[s]e aprovechó de la Biblioteca de su hermano el Dr. Don José María de Céspedes, uno de los catedráticos más eruditos que ha tenido la Universidad de la Habana" (1: 97), tanto, que llegó a ser Decano de su Facultad de Derecho, según Remos (8). José María gustaba de la literatura y realizó tertulias tan célebres como las de del Monte y las de Nicolás de Azcárate. Este hermano le proporcionó el estudio, principalmente el de los clásicos grecolatinos; incluso llegó a regalarle la Biblioteca de Autores Españoles de Rivadeneyra. En 1857, Úrsula Céspedes contrajo matrimonio con el poeta Ginés Escanaverino y al año siguiente, después de haber obtenido el título de maestra, fundó con él en Bayamo la academia Santa úrsula para la enseñanza femenina. Luego vivió en La Habana de 1863 a 1865. Posteriormente desempeñó su magisterio en Pinar del Río. Por la persecusión a que fue sometida durante la guerra de 1868, o de Diez Años, contra España, se traladó al lugar donde murió. Realmente úrsula Céspedes tuvo que huir a las provincias occidentales debido al acoso que sufrió su familia por el apellido que llevaba. Cuenta Soler Mirabent cómo su hijo Andrés fue expulsado del Colegio de Belén y su esposo amenazado de muerte (27). Su vida, producto de las luchas independentistas, estuvo llena de zozobras resumidas por Remos en su prólogo: 
Las repercusiones de la Guerra de Yara fueron

lacerantes para Úrsula: su padre había sido

sorprendido, vejado y encarcelado; su casa de Bayamo incendiada, confiscados sus bienes y destruídas las cosechas; y el quebranto y la humillación, la saña y el maltrato dieron al traste con su vida. A esta pena infinita, unía la poetisa la de la pérdida de cuatro hermanos que se habían unido a Carlos Manuel de Céspedes y que sucumbieron en la manigua; y simultáneamente, la de la muerte de una de sus hermanas, en La Habana. Desolados, presas de la más torturante angustia, abandonaron sus escuelas y fueron a refugiarse, abatidos por la más cruel adversidad, a la casa de la madre de úrsula, en Cienfuegos (14).

Todas estas tragedias se manifiestan en su últimas poesías compuestas hacia el final de su corta vida, las cuales se presentan llenas de tristeza y de motivos fúnebres e incluyen el presentimiento de su propia muerte. Soler cree que a esto se debe el "tono pesimista" (28) de su poética. Estas realidades propiciaron, como en Luisa Pérez de Zambrana, la elaboración de varias elegías: "Lágrimas," "En la muerte de mi padre," "Desaliento," "La muerte de una madre," "En la muerte 
del niño Faustino Gascón y Portillo" y "¡Está dormida!"34" entre otras.

Según Herrera de Herrera, sus primeros trabajos vieron la luz en El Redactor ${ }^{35}$ y El Semanario Cubano ${ }^{36}$, periódicos ambos de Santiago de Cuba (N. pág.). Luego durante su estancia en Villa Clara colaboró con La Alborada, El Progreso, El Eco de Villa Clara, El Fomento, La Hoja Económica, La Abeja y en el Correo de Trinidad. Colaboró también con La Prensa, de La Habana, y en las principales publicaciones nacionales de su momento, entre ellas El Kaleidoscopio, que dirigían Ramón Zambrana y Próspero Massana, así como en algunas de España y de México. Aparece en algunas antologías cubanas como en la Cuba poética de Joaquín Lorenzo Fuentes y José Fornaris de 1858. Se halla también en antologías extranjeras.

El primer poemario de Úrsula Céspedes, Ecos de la selva, tuvo un prólogo de Carlos Manuel de Céspedes ${ }^{37}$ y se cita como publicado en Santiago de Cuba ${ }^{38}$, en la Imp. de Espinel y Díaz, en el año de 1861 .

Al comentar su poesía Rocasolano afirma:

Sus versos presentan múltiples puntos de contacto con los de Luisa Pérez de Zambrana, de quien fue amiga y a quien precedió en la publicación de poemas en diarios y revistas. Sin embargo, la inestabilidad 
de su hogar, constantemente amenazado por la miseria, parece haber afectado sus posibilidades creadoras [...] ya que no logró configurar una obra a la altura de sus inquietudes. Su poesía, que presenta momentos excelentes, ha sido injustamente preterida. La delicadeza de sus elegías, la emotividad con que capta nuestra naturaleza y la atmósfera general de su quehacer poético, la sitúan entre las buenas poetisas de la segunda mitad del $[\ldots]$ siglo $[X I X](54)$.

Cintio Vitier, comparándola con Julia Pérez Montes de Oca, sólo la nombra para decir que es una "poetisa [...] de mucho menos valor" (222). Carlos Ripoll, sin embargo, cree que "fue, [junto] con Luisa Pérez de Zambrana y Julia Pérez Montes de Oca, una de las tres mayores elegíacas campestres del segundo romanticismo cubano" (52). A lo que se adjunta el comentario de González Curquejo: "[m]uchas de sus poesías que se hallan regadas por los periódicos, la acreditan cómo una de las poetisas de más mérito que ha producido Cuba" (1: 97).

En su poesía donde, según Remos, "la cabeza es poca cosa y el corazón lo es todo [...]" (21), se alcanza un más allá de tal afirmación, pues sus textos hablan, además, de soledades, de cadáveres y de la atmósfera de las necrópolis. Son lúgubres 
y se refieren al inefable puente entre la vida y la muerte. Pero también cantan a la naturaleza, reflexionan sobre las diferencias de clase, de la sociedad en general, así como sobre los marginados. Mendigos, criminales, esclavos, actrices y prostitutas se mezclan con los ricos. Sus formas predilectas, según sus estudiosos, fueron la silva, el romance y la décima.

Uno de sus poemas se titula "El Cementerio de La Habana ${ }^{39}$ " según Curquejo, alude al antiguo Cementerio de Espada, ya demolido. En él se encuentra, además de lo descriptivo, señalado por Remos, la preponderancia de motivos fúnebres, tan propia del romanticismo:

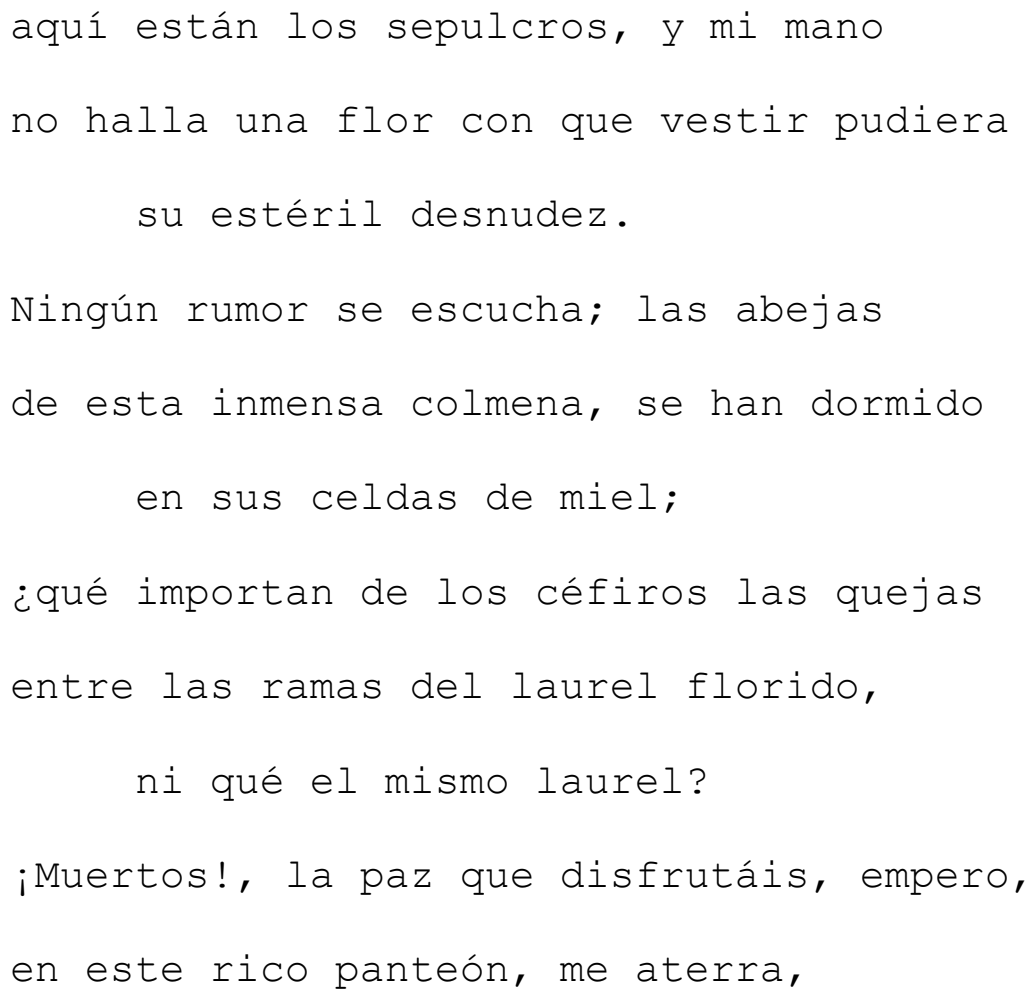




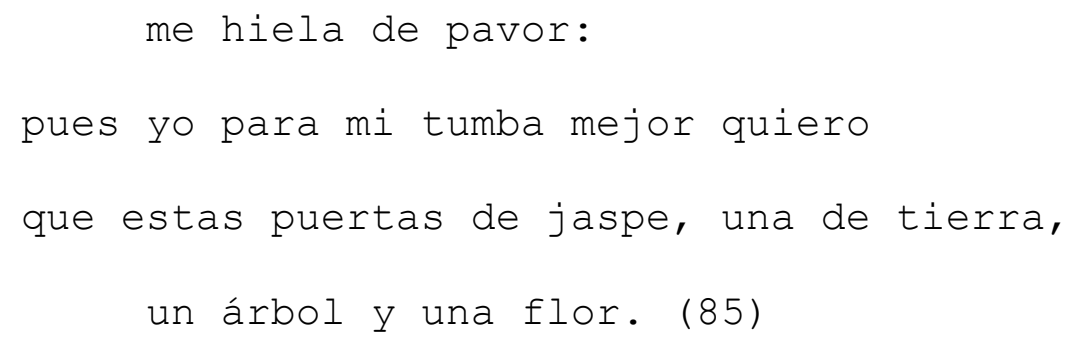

Según Antonia Soler, en Cuatro poetas, los últimos versos de este poema "se pueden leer en el mausoleo que guarda sus restos" (25). Mausoleo que, según la misma Soler, se debió al dinero recaudado por José A. Triay, en 1885, quien publicó un artículo en la revista La Lotería, donde recababa la contribución del pueblo para dicho fin.

En "¿Qué soy?-¿De dónde vengo?-¿Adónde voy?" ", trata de responderse las eternas preguntas. Los primeros versos de esta filosófica composición dicen:

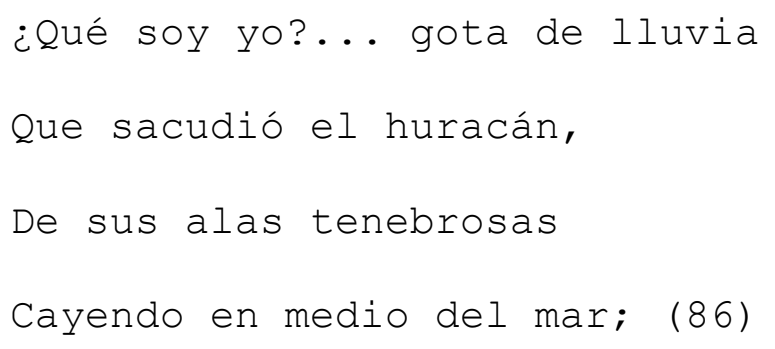

En la última estrofa, de este poema donde se manifiesta además la pequeñez del ser humano ante el universo, encontramos cuestionamientos que recuerdan al Rubén Darío de "Lo fatal," publicado algunos años después (1905).

¿Quién soy yo? Jirón de nube Que dejó la tempestad. 
¿De dónde vengo? Del caos.

¿A dónde voy? Mas allá... (87)

Ideas de contenido filosófico también aparecen en su composición "Las mariposas del alba," que por no hallarse en la recopilación de Remos se toma de la antología de González Curquejo. Allí habla de la flora y la fauna del país y se compara con una mariposa. Las últimas estrofas versan:

Así amaneció en mi vida.

Fresca y pura, una mañana;

Realización venturosa

De los sueños de la infancia.

Llegaba á todas las fuentes

Para desdeñar sus aguas;

Porque la sed que sentía

Ninguna fuente apagaba.

Pero llega el mediodía,

El sol mis campos abrasa,

Y mueren todas mis flores,

Todos mis céfiros callan...

Vuelvo los ojos al cielo, 


\section{Y plego triste las alas;}

Para morir como mueren

Las mariposas del alba. (101)

No sólo, como vemos, habla de la naturaleza sino que se compara con un ser etéreo y de vida breve. De niña la poeta está en la búsqueda de cuestionamientos que no alcanza a comprender. Es una mujer inteligente, cultivada, dentro de una familia de profesionales. De adulta, al mediodía de su vida, la creadora ya sabe cuáles son sus fronteras, lo que puede o no hacer. No le queda más remedio que pedir y obedecer "plegar sus alas," como signo de inactividad, de dejar de hacer, de morir como intelectual. No tenía que ir muy lejos, para hacer la comparación sólo le bastaba mirar el camino recorrido por su hermano, muy distante de ser simplemente un graduado universitario.

Las mariposas, como expresión de la brevedad de la vida, estuvieron presentes en otra composición de Úrsula, fechada en $1852^{41}$, cuando tenía veinte años. Además de la reflexión sobre el tiempo, es interesante la originalidad de la estructura, inusual, del texto. Escogemos algunas de sus estrofas seguidas para ilustrarlo:

\footnotetext{
Tú nunca cuentas las horas

y no lloras
} 


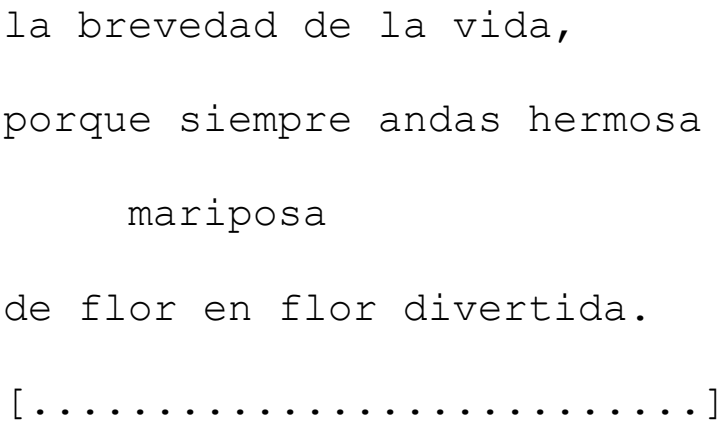

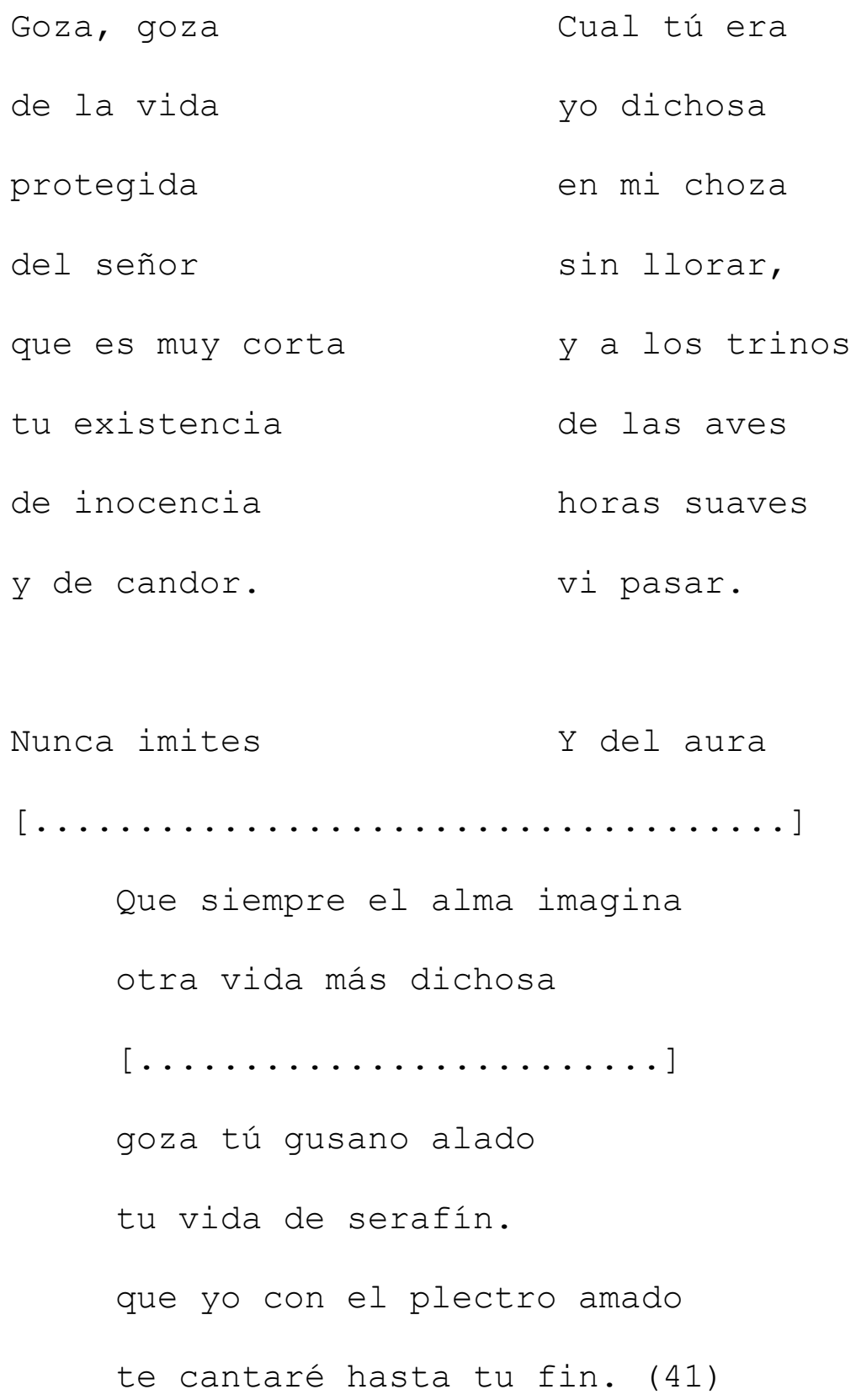


Esta preocupación por lo efímero la trata en uno de sus mejores textos, "El tiempo," donde están presentes, de una forma indirecta, las ruinas, motivo común en el movimiento romántico:

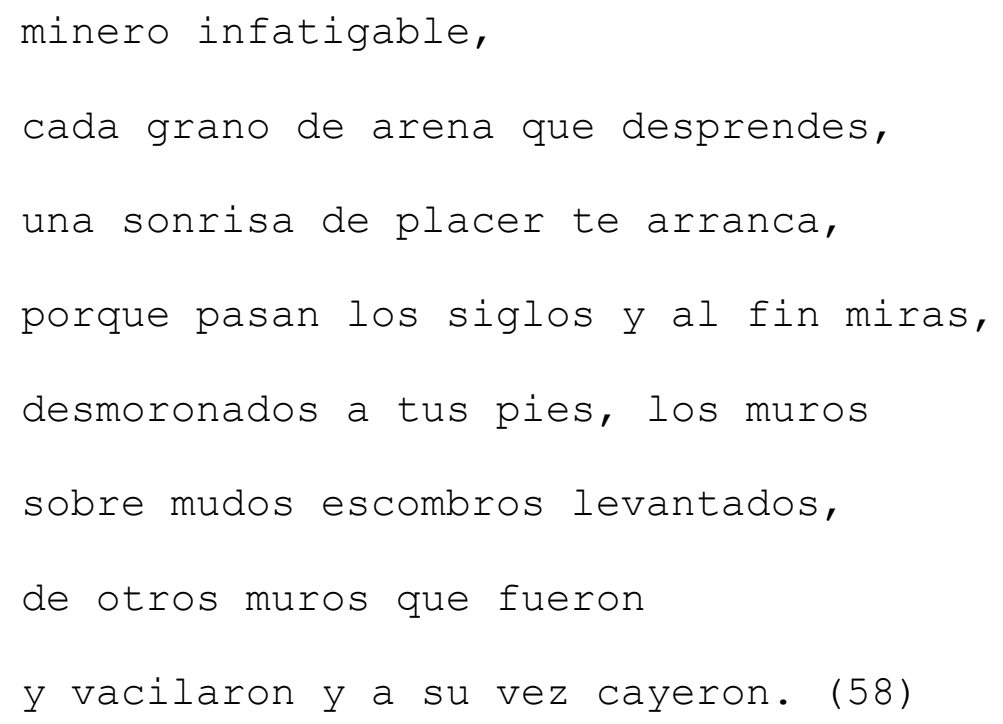

"Retorno a Bayamo," canta a la ciudad de su nacimiento y vuelve nuevamente a la naturaleza, aquí la de su suelo. Este amor por lo bucólico ya aparece en ella desde los dieciséis años cuando compone "El arroyo," fechado en el Bayamo de 1848 . No escapó, dentro de este reflejar su entorno adolescente, el proyectar lo que Remos llama "tendencia tropicalista" (24), así como su "tributo a la musa popular" (24) en "El amor de la serrana," "La serrana y el veguero," en forma de décimas, y en el romance "Consejos de un guajiro." En "La serrana y el veguero," se refleja la religiosidad de Úrsula Céspedes cuando habla de los planes de vida en un bohío que tendrán: "habrá un 
destruya el hado su paterno nido, cuando se sienta el corazón herido

y se halle sola en su dolor profundo?

La poeta misma se responde; vierte su opinión en la estrofa que sigue a la anterior:

Flor arrastrada a lodazal inmundo, cordera lejos del redil querido, buque sin jarcias por el mar perdido, triste ludibrio del gigante mundo. (48) Luego se encuentra con quien la convierte en esposa, y que ella ve como una tabla de salvación:

$$
\begin{aligned}
& \text { Así exclamaba y al volver los ojos } \\
& \text { te encontré en el camino de mi vida, } \\
& {[\ldots \ldots \ldots \ldots \ldots \ldots \ldots \ldots \ldots \ldots \ldots \ldots \ldots \ldots \ldots} \\
& \text { pedí tu apoyo y me llamaste esposa. } \\
& {[\ldots \ldots \ldots \ldots \ldots \ldots \ldots \ldots \ldots \ldots \ldots \ldots \ldots \ldots \ldots} \\
& \text { y ahora, apoyo de mi vida, ahora, } \\
& \text { eres mi Dios, mi protector, mi amigo. (48) }
\end{aligned}
$$

Finalmente la servidumbre es total: "yo te llamo mi dueño y te bendigo" (49) .

El tema de los marginados, común al romanticismo, se ve también en Úrsula Céspedes; y, entre ellos, el de la esclavitud. El poema "Los negros del palenque," que soler 
llama "completamente reaccionario, en donde nos presenta el negro como un salvaje" (32), debe ser leído con mucha cautela, pues el mensaje es ambiguo. En esta obra, los africanos maldicen a los tiranos. En los cuatro últimos versos de la tercera estrofa lo que aparece es una idea muy avanzada de la igualdad entre el hombre y la mujer. Dicen los esclavos fugitivos del palenque:

y aquí nuestras mujeres

serán esposas y serán amigas,

partirán con nosotros los placeres

y nosotros con ellas las fatigas. (51)

Es decir, en estos seres que han huido de la esclavitud, que viven con cierta libertad, sin tiranos ni leyes, hay más igualdad entre el hombre y la mujer. No es reaccionario el mensaje, es de avance social en cuanto a la liberación femenina. En una de las últimas estrofas aclara úrsula Céspedes:

$$
\begin{aligned}
& \text { Radió por fin la luz, y aquellos hombres } \\
& \text { hacía poco tan llenos de alegría, } \\
& \text { que formaban cual horda de bandidos } \\
& \text { se amaban sin embargo como hermanos. (52) }
\end{aligned}
$$

En comparación con la sociedad blanca que los esclavizaba y no los tenía como seres humanos, decir que ellos se amaban como 


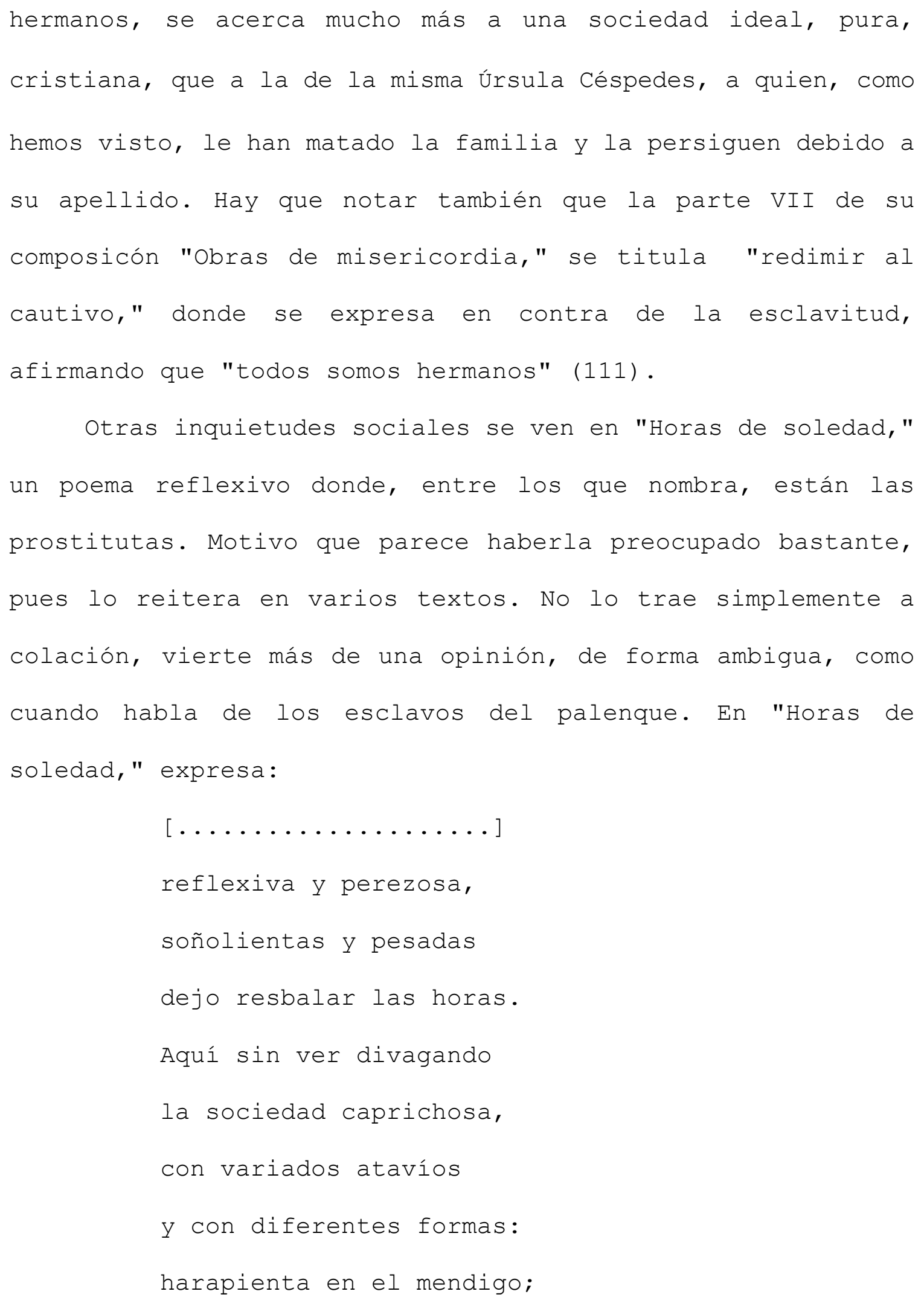


Posteriormente comienza a preguntarse a dónde se fueron sus ocupantes. Es aquí donde vuelve a aparecer la prostituta:

$$
\begin{aligned}
& \text { ¿A dónde fueron los niños } \\
& \text { que jugaban en tu orilla, } \\
& \text { y el huérfano que lloraba }
\end{aligned}
$$




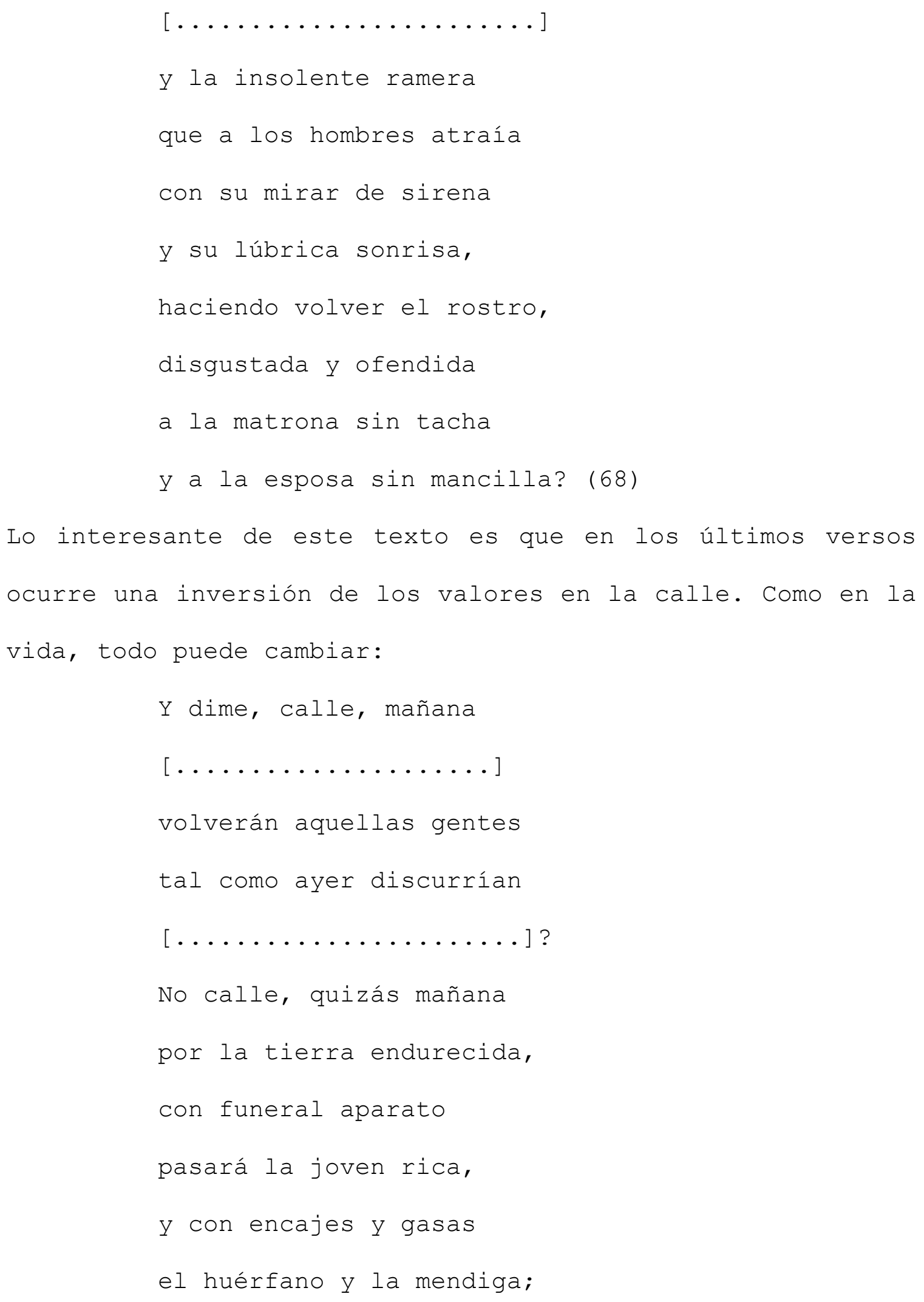


$[\ldots \ldots \ldots \ldots \ldots \ldots \ldots]$

la meretriz será madre

y esposa tierna y sencilla,

y la matrona sin mancha

llevará la faz teñida

del rubor de la vergüenza

- el bermellón de la envidia. (69-70)

En este texto se demuestra que úrsula Céspedes hace un acercamiento al tema de la prostitución. No sólo lo expone, sino que piensa en el mismo, y expresa, valientemente para la época, que cualquiera de esos "ángeles del hogar," puros y asexuados, de la sociedad decimonónica que habita, puede ser, el día de mañana, una prostituta. En este poema, sutilmente, defiende de una manera oscura, cierto, la idea de que dentro de cada mujer hay un ser sexuado, que siente, a tal punto que de ángel puede pasar a ramera; y que ésta tiene la oportunidad de convertirse en esposa y en madre. Es decir, en lo que era ella misma, y neutraliza cualquier crítica. Aunque el mensaje parecería ambiguo, lo que está haciendo Úrsula es defender a la prostituta y con ello, pensando en su "hipererotismo," por darle un nombre, a la sexualidad femenina.

"Consejos de un guajiro," muestra una tendencia didáctica, señalada por algunos críticos y que quizás tenga 
que ver con la maestra que fue su autora. En estos versos, Úrsula Céspedes nuevamente retoma el papel masculino para aconsejar a otro hombre, hijo de un campesino. En la cuarta estrofa, de veintitrés que posee el poema, lo vemos:

El hombre justo y honrado, trabajador y sin vicios, tiene paz en la conciencia y dinero en el bolsillo. (94)

Esta tendencia didáctica de Úrsula Céspedes también se observa en un poema, -en González Curquejo- dedicado a Andrés Pablo, su hijo. El texto, lleno de advertencias sobre la vida, habla del oficio de la creación que junta con otras labores:

La ociosidad es madre del hastío.

Y más tarde del vicio y la impostura:

El trabajo da fuerza y albedrío,

Felicidad y bienestar procura:

Los hombres laboriosos hijo mío,

No han lugar de sentir la desventura;

Y la pluma, la espada, ó el arado,

No dejan tiempo para ser malvado. (106)

Indirectamente, en el mismo texto, sin embargo, habla mal del género femenino y expresa un sentimiento patriarcal y de 
época: "Los banquetes, el vino, las mujeres,/Son quimeras no más, hijas del vicio" (106).

En "El huérfano ${ }^{42}$ " compuesto cuando tenía 26 años, tomado también de González Curquejo, utiliza a un niño, que ha caído en las manos de alguien que no le ama, para criticar su sociedad: "Porque iay! triste del huérfano lanzado/Entre las garras de este mundo impío" (102).

Profunda es otra composición, "La felicidad," donde vemos su preocupación por las desigualdades entre los hombres:

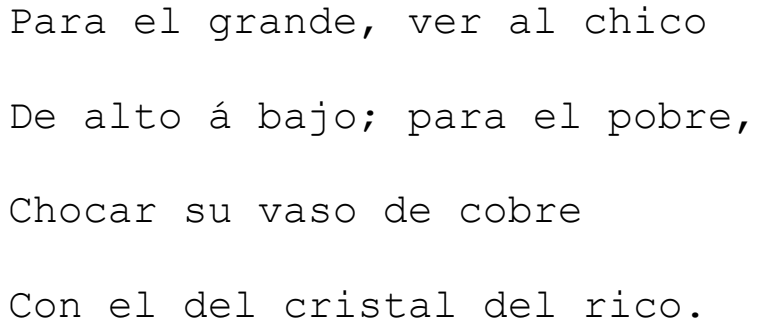

(González Curquejo 1: 108)

Las composiciones donde canta a la muerte se reiteran, lo que la sitúa entre las elegíacas cubanas, específicamente al lado de Luisa Pérez de Zambrana. Uno de sus poemas más nombrados es "Está dormida," hecho a una de sus alumnas, cuya primera estrofa dice:

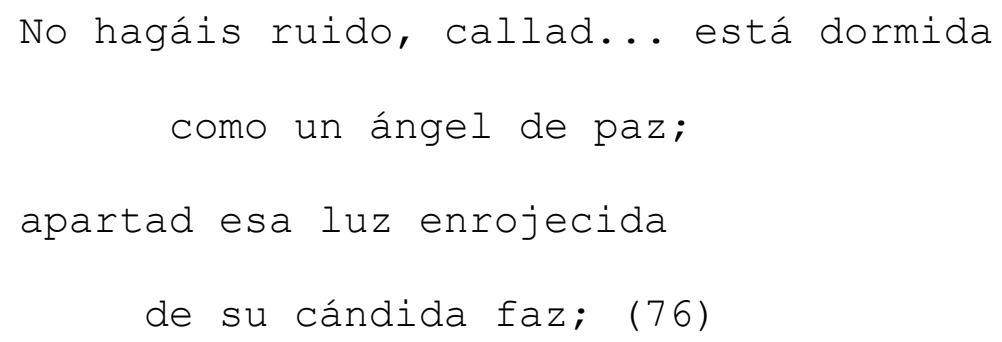


En este texto también se toman, brevemente, motivos bíblicos:

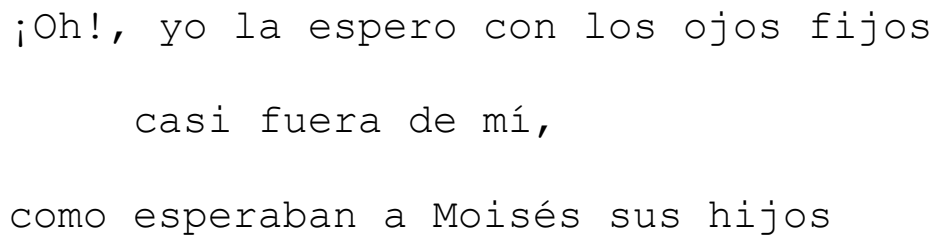

Según describe Soler refiriéndose a esta composición:

En la selección de este poema como uno de los más hermosos y logrados de Úrsula, coinciden modernamente los críticos Jose Manuel Carbonell, Juan J. Remos, Raimundo Lazo, Cintio Vitier; y ya Carlos Manuel de Céspedes [...], en el prólogo al libro Ecos de la selva, nos decía que "es de lo mejor que úrsula ha escrito" (29) .

Hacia el final de su vida los motivos de su poesía fueron haciéndose cada vez más lúgubres, cargados de tristeza y de premoniciones. En "El ángel de la muerte," fechado en Regla, en 1873, expresa en su cuarta estrofa, al hablar a tal aparición:

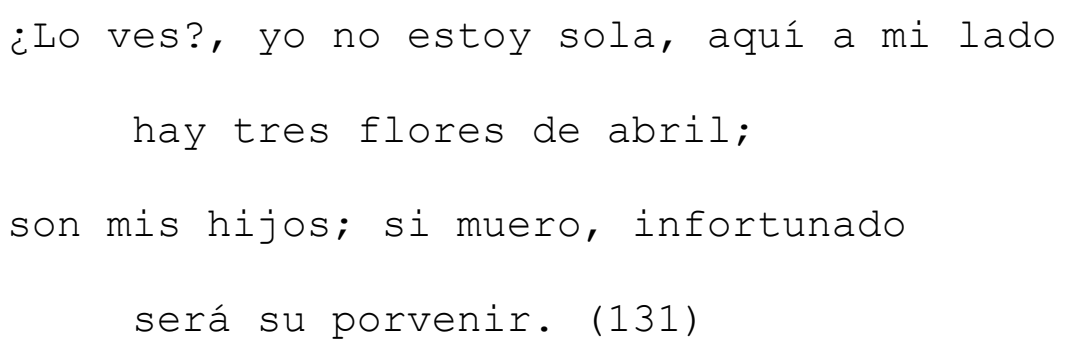


Nunca me he separado de esos seres

que nacieron de mí;

¿a qué, pues, has venido?... ¿qué me quieres?

¡yo no puedo morir! (132)

En el año 1834, el de su muerte, escribe en Cienfuegos "El ángel," que se refiere a su hija de quince años y donde ya es evidente que espera el fin:

De lámpara funeraria

la tenue luz ilumina

con moribundo temblor,

las sombras de mi alcoba solitaria,

y sábanas revueltas del lecho de dolor.

Y, cuando expresa:

Mi triste vida se exhala

en un perpetuo gemido

$[\ldots \ldots \ldots \ldots \ldots \ldots \ldots \ldots \ldots$

Mi sueño es un desvarío

una angustia continua; (133)

no está haciendo otra cosa que describir los estados finales de un padecimiento que la consume. La edad de la muerte: los 42 años, así como el autorretrato que nos pinta aquí, parecen indicarlo. Una enfermedad la estaba llevando a la caquexia y a pensar en su próxima desaparición. Refiriéndose a su hija lo 
expresa: "En mi rostro enflaquecido/ siento el suyo terso y suave/como de cisne el plumón" (134). Los últimos versos hablan de cuán difícil se le hacía su óbito y cuán consciente estaba de que iba a ocurrir:

Tú no quieres hija mía, separarte de mi lado

y no me dejas partir,

pues si miro, al entrar en la agonía.

tu rostro idolatrado, jamás podré morir. (135)

La sutileza de "Las mariposas del alba," así como el tema de la prostitución, como máximo exponente de la sexualidad desbordada, ante la mirada patriarcal y religiosa de época, manifiestan que Úrsula Céspedes tenía conciencia de la mujer de su tiempo. No una conciencia feminista como la vemos hoy, pues nada en su poesía implica una defensa o una queja abierta de su situación. Hay, no obstante, otros hechos de su vida que, indirectamente, dicen de estas luchas o, al menos, demuestran tener conocimiento de ellas. Me refiero a la fundación de la academia Santa Úrsula, para la enseñanza femenina, así como el empleo de un seudónimo masculino (énfasis nuestro). 


\section{Luisa Pérez Montes de Oca.}

Nació en la finca Melgarejo, cercana al Cobre ${ }^{43}$, Oriente, el 25 de agosto de 183544. Aclara Rocasolano: "[p]or deducción, este año es aceptado actualmente como el de su nacimiento, aunque hasta el presente han resultado infructuosas todas las gestiones [hechas] con el fin de localizar su fe de baustismo" (64). Sus padres, según René León, fueron Joaquín Pérez Naranjo, natural de Islas Canarias y su madre, Justa Germana Montes de Oca (1), de la misma localidad que sus hijas. Luego de su matrimonio con el Dr. Ramón Zambrana, la poeta sería conocida como Pérez de

Zambrana. Muere el 25 de mayo de 1922, al decir de Rocasolano "en el ultramarino pueblo de Regla" (64). Sus restos se encuentran en el Cementerio de Colón, en La Habana donde, firmado por Malleén Zambrana, puede leerse en su tumba: "A la memoria de la inmortal poetisa Luisa Pérez de Zambrana ${ }^{45}$."

Dos años y medio después de muerta Gertrudis Gómez de Avellaneda ${ }^{46}$, hace José Martí en su crítica del libro Poetisas americanas, editado por José Domíguez Cortés y aparecida en la Revista Universal de México, un muy duro análisis de la misma al compararla con Pérez de Zambrana. Previamente se refiere al editor como "poco escrupuloso" (134) y luego: "[h] ay un hombre altivo, a las veces fiero, en la poesía de la 
Avellaneda" (134). Sin embargo, seguidamente afirma de Pérez de Zambrana: "hay en todos los versos de Luisa un alma clara de mujer." Más adelante desdeña en su ensayo a la camagüeyana: No hay mujer en Gertrudis Gómez de Avellaneda: todo anunciaba en ella un ánimo potente y varonil; era su cuerpo alto y robusto, como su poesía ruda y enérgica; no tuvieron las ternuras miradas para sus ojos, llenos siempre de extraño fulgor y de dominio: era algo así como una nube amenazante. Luisa Pérez es algo como nube de nácar y azul en tarde serena $y$ bonacible. Sus dolores son lágrimas, los de la Avellaneda son fiereza. Más: la Avellaneda no sintió el dolor humano: era más alta y más potente que él; su pesar era una roca; el de Luisa, una flor. Violeta casta, nelumbio quejumbroso, pasionaria triste. (136), (énfasis nuestro).

Este solo pensamiento martiano serviría para estudiar cómo era vista una mujer que mostrara su inteligencia y su superioridad ante el hombre. Martí no podía concebir a una mujer que se le igualara, por eso realza a Luisa Pérez de Zambrana, quien, aparentemente, es dócil, sumisa al hombre y a las reglas de urbanidad que exigía su tiempo. 
Es posible que, como trasfondo a esa actitud martiana, esté también el "alejamiento" cubano de la Avellaneda, y quizás sea por eso que entre las dos, considerara a Luisa Pérez de Zambrana como la mejor poetisa americana (Martí 136). No podemos descartar, totalmente, algo netamente humano: los celos por la fama de la compatriota. Es real que, después de la camagüeyana, la poeta cubana más importante del siglo XIX es Luisa Pérez de Zambrana.

Pérez de Zambrana publicó, además, dos novelas: Angélica $\underline{\text { E Estrella }}$ y La hija del verdugo. Pero es de su narrativa de la que menos se habla por no tener el valor literario de su poesía, a tal punto que Max Henríquez Ureña dice que "no se distinguió como prosista" (1: 317). Llegó a escribir también algunos artículos periodísticos sobre mujeres célebres.

Eugenio Florit, en su ensayo "Algunas anticipaciones de la Avellaneda" afirma que Luisa Pérez de Zambrana "tiene sólo una cuerda, maravillosa por sus sentimientos, sí; pero limitada a ello mismo" (54). Por fortuna para la poeta, su lírica va más allá de esta única cuerda que menciona Florit, salvo que, precisamente por el orden patriarcal, doblegó su poesía sin que pudiera evitar algún asomo, aunque suficiente, de su conciencia de oprimida. María A. Salgado ha dicho al respecto: "su limitada temática refleja su restringido radio 
de acción: la escasa oportunidad que en sus días se le ofrecía a una mujer culta pero falta de recursos económicos" (215) . No obstante, Max Henríquez Ureña comenta que "aunque [...] no aspirara a ser poeta social ni esa tendencia fuera la más adecuada a su temperamento soñador, desde sus primeros balbuceos poéticos asumió una posición ideológica contraria a toda opresión o tiranía, sea la del rico que explota al pobre, sea la del fuerte que aniquila al débil" (1: 313).

De origen rural, Luisa Pérez de Zambrana pasó su niñez en el campo, próximo a la villa minera de El Cobre ${ }^{47}$ en las cercanías de la Sierra Maestra. Rocasolano dice cómo, "adolescente aún, llamó poderosamente la atención con sus versos: primero [la] de sus coterráneos y de los círculos literarios de Santiago de Cuba y, algo después, [la] de los literatos de la capital" (64). Y amplía:

Su poesía inicial está traspasada por el «universo» rural en que le tocó desenvolverse. En 1852 apareció en El orden, de Santiago de Cuba, su primer poema publicado. Ese mismo año, tras la muerte de su padre, se trasladó con su familia a la mencionada ciudad. La frescura y espontaneidad de sus poemas revolucionaron la capital oriental, y La Habana 
siguió atenta los pasos del grupo santiaguero, donde Luisa brillaba -y deslumbraba- con luz propia. (64) En 1857, cuando sale Poesías de la señorita Da. Luisa Pérez y Montes de Oca, su primer libro, tenía 21 años. El poemario fue prologado por Federico García Copley, animador del grupo santiaguero, quien comenta allí: "muy próxima está aún la época en que empezaron a escucharse sus deliciosos cantos; y en tal tiempo ha logrado conquistar un lugar distinguido en la naciente república literaria cubana" (115) . Y aclara Copley que el hecho es singular, pues este prestigio generalmente se encuentra después de "un largo transcurso de tiempo" (115). Aunque su primer texto "Amor materno" data de cuando tenía catorce años -Max Henríquez Ureña afirma que fue a los dieciséis-, se refiere aquí a los poemas que ya Luisa Pérez de Zambrana había empezado a publicar, el primero a los 17 años.

A través de las palabras de García Copley se respira la atmósfera de la medianía del siglo XIX y de lo que se consideraba lógico de la escritura femenina. Habla el prologuista de los temas que se observaban en la lírica de entonces y menciona "ora las excelencias de la religión y de la moral" (117), e inmediatamente, se refire a los autores que seguían estas normas: "[e]ntre ellos figura la apreciable 
autora de las producciones a que precede este escrito" (117). Después, mientras habla de la poeta añade: "compartía el tiempo entre las labores de su sexo a las cuales debía su subsistencia y la de su familia" (118), (énfasis nuestro).

Desde la diacronía con que se mira lo anterior, se explica lo bien diferenciado que estaban los papeles de lo "masculino" y lo "propiamente femenino." Luisa Pérez de Zambrana, la mayoría de las veces, dio muestras de lo que se esperaba y "aparentemente" no infringió la moral ni los conceptos de su tiempo. Hoy, gracias a una estrofa escrita un año antes del prólogo de García, así como por el análisis de otros poemas, sabemos que realmente pensaba muy diferente de este intelectual y que arrostraba lo que entonces, y aún, se toma como natural: el papel asignado a la mujer en la sociedad. Sin embargo, se narra en palabras de García Copley, cómo, inspiradas por las composiciones de Luisa Pérez, las mujeres comenzaron a colaborar, con prosa y verso, en el periódico El Orden de Santiago de Cuba. Ella, según éste, "inauguró un período de prosperidad y brillantez" (118) para la publicación. Refiriéndose a los temas de la creadora, dice García Copley:

\footnotetext{
se encuentran en los cantos de nuestra compatriota un fondo riquísimo de verdadera inspiración,
} 
facilidad y abundancia en los conceptos, las expresiones propias de un alma contemplativa y dispuesta a todo lo bueno: si canta a la religión, uno de sus asuntos predilectos, encanta y eleva la unión envidiable y la fe firme y profunda que brilla en todos sus pensamientos; si describe los cuadros de la naturaleza sorprende la exactitud en la pintura de los objetos, en los cuales imprime el colorido de la verdadera poesía; si expresa el amor filial o algún otro afecto idéntico, conmueve a la ternura que vierte a raudales; y si eleva su voz a Cuba, entusiasman sus arranques de acendrado y puro patriotismo, y cautiva y enternece si pinta la simpatía que en las almas de elevado temple excitan las acciones virtuosas. (119)

A pesar de esa interpretación, siempre en elogio a la riqueza poética de Luisa Pérez de Zambrana, le hace posteriormente algunas críticas: "[n]o afirmaremos por cierto que las producciones de que nos ocupamos carecen de defectos, hállanse en gran número así en las ideas como en el lenguaje" (119) (énfasis nuestro), señalados como debido a que "la imperfección es achaque de todo lo humano" (119). No sabemos hoy si en eso de las ideas expresadas, García se refiere a las 
que se encuentran en la composición llamada "Contestación," -poema que, fechado en "enero de 1855," según Sergio Chaple, "apareció publicado el 11 de enero de 1855 bajo el título de «Contestación a un amigo» en la revista Semanario Cubano [y que clon numerosas variantes fue recogido en la edición de 1856" (103). Pero he aquí un dato que lo hace muy importante y que también aporta Chaple: "[e]n las restantes ediciones de sus obras, la autora decidió no incluirlo" (103). Siendo como es un texto tan hermoso y visionario, ¿qué lleva a Luisa Pérez a deshacerse, a esconder, en otras palabras, esta composición? ¿Los comentarios de su prologuista, o la madurez y la conciencia de que si su lírica seguía ese camino iba a entrar en contradicciones con el statu quo de la sociedad de la Isla? Nada ciertamente sabemos, pero tenemos el poema, y éste habla por sí solo. Max Henríquez Ureña, en su Panorama histórico de la literatura cubana nos aclara el camino en relación con sus poemas eliminados:

Sólo veintidós composiciones de las cincuenta y una que integran el volumen de 1856 pasaron a formar parte de la colección de 1860. Aquellas que encerraban alguna queja o protesta contra el orden social establecido sufrieron modificaciones esenciales [...] o fueron eliminados [...] 
seguramente para evitar interpretaciones

inconvenientes por parte de la censura, cada vez más intolerante y arbitraria, sin que esta medida de elemental prudencia pueda tomarse como indicio de que los sentimientos e ideas de Luisa habían cambiado. (1: 316), (énfasis nuestro).

Cuando su primer libro llega a La Habana, a las manos del Dr. Ramón Zambrana, escritor y médico, a la sazón reputado literato, comenzó con su autora un intercambio epistolar que el 16 de septiembre de 1858 concluyó en matrimonio. Entonces la poeta se trasladó a vivir en la capital del país.

En 1860 publicó su segundo poemario que lleva un breve prólogo de Gertrudis Gómez de Avellaneda. El 27 de enero de igual año, Luisa Pérez de Zambrana, junto a Elena Martín y Molina, Condesa de Santovenia, colocó, en el Teatro Tacón de La Habana, la famosa corona de laurel -de oro macizo- a la camagüeyana. Pérez le dedicó, en tal ocasión, su "Soneto en la coronación de la Avellaneda," leído durante la ceremonia. Es decir, que existía una relación de amistad entre ambas, no obstante los valores que había ido adquiriendo la obra de Luisa Pérez de Zambrana. Esta amistad puede verse como consecuencia de la notoriedad que había alcanzado su labor poética. La Avellaneda, en su introducción, señala que se 
trata de una creadora y afirma que este segundo poemario "es fruto de un poeta cubano, que es además mujer y como tal poseedor de organización singularmente privilegiada para el entusiasmo y el idealismo" (125). También se analiza que pueden encontrarse allí, si se busca, "la imagen del estado moral e intelectual del joven país a que pertenece la autora" (125). Resulta interesante este planteamiento de Gertrudis Gómez de Avellaneda, pues en Pérez de Zambrana este pensamiento se manifiesta no sólo en lo que refleja sino en lo que deja de expresar y que juega con un verso de su poema "Melancolía," como veremos posteriormente.

Además del espíritu de época, la Avellaneda señala, ya desde ese momento, que en su poesía "hay esa vaguedad de la melancolía que seduce y atrae" (126), y hace hincapié en la religiosidad de Pérez de Zambrana, lo que quizás explique por qué prefirió una actitud resignada de soportar el dolor, de no quejarse para no crearse conflictos como sí se los buscó y afrontó la liberada camagüeyana, la cual no obstante haberle señalado, como García Copley, "descuidos e incorreciones lamentables" (129), la vio como "una individualidad poética" (129) y anunció, con un criterio profético, "la naciente literatura cubana le conservará entre sus mejores joyas" (129) 
En la capital, Luisa Pérez de Zambrana se puso en contacto con la más importante intelectualidad habanera, y entre ella con Rafael María de Mendive y con Nicolás Azcárate, en cuyas tertulias tomó parte. Aquellos trabajos fueron publicados un año después, en 1866. Por su prólogo, que Azcárate llama "Advertencia," sabemos que en esta edición, no se recoge todo lo que se leyó en dichas reuniones, pues estuvo presente un "Sr. Censor de Imprenta" que a veces "no ha autorizado la impresión [de alguno de los textos]" (1: VI). En los tomos aparecen varias figuras de época, cuyos ecos nos llegan hasta hoy. Además de Luisa Pérez de Zambrana y de su hermana Julia Pérez Montes de Oca, se encuentran allí Mercedes Valdés Mendoza, María de Santa Cruz, Joaquín Lorenzo Luaces, José Fornaris, Rafael María de Mendive ${ }^{48}$, Felipe Poey, Juan Clemente Zenea, Ramón Zambrana y el mismo Nicolás Azcárate, entre otros. En su introducción, sin embargo, Azcárate exalta, al nombrarla con un verso, a una sóla: Luisa Pérez de Zambrana.

Es interesante el comentario que hace José Silverio Jorrín, otro de los asistentes, en su "Improvisación," en relación con quienes allí se reunían: "veo aquí agrupados entre discretísimas señoras, artistas y poetas, catedráticos y magistrados, funcionarios públicos y periodistas" (1: 320). 
Nótese la visión menoscabadora de Jorrín, pues, hombre de su época, entre las "discretísimas señoras" de las que habla, sutilmente apartándolas de los creadores -"artistas y poetas-," estaba Luisa Pérez de Zambrana, la más grande elegíaca cubana de todos los tiempos.

En 1866 muere el esposo de Luisa Pérez de Zambrana luego de ocho años de matrimonio, y antes de 1898 ya había perdido a sus cinco hijos ${ }^{49}$. Es la época cuando escribe sus grandes elegías. Según Rocasolano, vivió después olvidada sufriendo de soledad y pobreza hasta que en 1908 le fuera concedida una modesta pensión por el Ayuntamiento de La Habana, la cual disfrutó el resto de sus días. Con el propósito de reparar el injusto olvido en que vivía, el Ateneo de La Habana la homenajeó en 1918, acto en el que participaron José María Chacón y Calvo, Gustavo Sánchez Galarraga, Dulce María Borrero de Luján y Enrique José Varona, nombres claves de la cultura cubana. Prologados por este último, en 1920 se publicó una nueva edición de sus versos, sesenta años después de la anterior cuando Luisa Pérez de Zambrana aún vivía y se había convertido ya en una gran figura de las letras. Haciendo un resumen de los motivos a los cuales había cantado la poeta, Varona señala inicialmente la naturaleza, más bien "la impresión profunda producida en el alma de la autora por 
aquella grandiosa contemplación" (7), así como la melancolía que vive en su obra, luego de las pérdidas familiares.

Basado en ese "golpear persistente de las grandes desgracias" (85) Raimundo Lazo la nombra "la poetisa del dolor" (85). Dolor que es la respuesta a su infortunio real "lo que irá a reflejarse y a condicionar una poesía más dramática y vivencial" (Gutiérrez-Vega 193). Lezama Lima habla de esta poética como lo más logrado de su obra que abarcó el ya señalado amor a la naturaleza, lo religioso, lo patriótico y lo social. Cintio Vitier, la junta al romántico Juan Clemente Zenea y dice: "[c]omienza ya con ellos, limpia de toda mezcla, una lírica purísima del alma, de la intimidad y de las soledades" (183). Luego, también Cintio Vitier, en Lo cubano en la poesía, al hablar de ella utiliza los adjetivos y frases siguientes: "delicadeza," "candor del alma," "vaporosos poemas," "es el suyo un mundo trémulo, pudorosamente cubierto por un velo de luz," "la extasiada muchacha del genio suave de la isla," "delicada Ofelia insular," "pureza del tono;" es decir prácticamente se remonta al "ángel del hogar" decimonónico.

La interpretacion de Vitier, sin embargo, queda incompleta, pues no muestra la verdadera Luisa Pérez de Zambrana, quien si bien es todo esto, lo es de hecho porque la 
sociedad patriarcal, con sus sutiles métodos, la obligó a serlo. Ya demostraremos más adelante cómo esta creadora, por fortuna, va más allá de la "etérea" mirada que le echa Cintio Vitier. Una mirada que debe enriquecerse para una interpretación femenina de una de las mejores poetas cubanas del siglo XIX. Creo que inconsciente o conscientemente, Vitier, y muchos de los críticos cubanos, siguen los pasos de José Martí a quien no contradicen al hablar de ella. Es decir, para este estudioso, Luisa Pérez de Zambrana sigue siendo la humilde y pura violeta que describió Martí, lo cual, como continuación de una línea de pensamiento, es muy discutible. Ahora bien, si en Martí, que empleaba tanto los símbolos, Luisa Pérez de Zambrana aparece como una violeta, hay que indagar el por qué. Cuando Ivan A. Schulman explica lo que significa dicha flor en la obra martiana afirma: "lo mismo como flor que como color, representa la belleza, la modestia, la humildad y los aspectos tristes y dolorosos de la vida humana" (242). Es decir, no vio Martí -o no quiso ver-, empeñado en compararla con la Avellaneda, otras manifestaciones de Pérez de Zambrana, unas aparentemente dichas con toda sutileza y otras directamente, como analizaremos. 
En el brillante ensayo de María A. Salgado: "Desenmascarando el cuadro: El autorretrato de Luisa Pérez de Zambrana," se estudia con profundidad su texto "A mi amigo A. L," que Chaple nombra "quizás el mejor retrato de una poetisa cubana y una de las composiciones más representativas de Luisa" (105), que aparece con fecha "febrero de 1857" (105). Tuvo un título original "A mi amigo A. L. al querer retratarme sobre un pedestal, coronad[a] de laurel y pulsando una lira" (105). Fue, según Chaple, incluido por la autora en todas las ediciones de sus obras aunque con ligeros cambios, lo cual según sus investigadores era su costumbre.

El texto 50 íntegro sobre el que se trabajará es el que sigue:

A mi amigo A. $\mathrm{L}^{51}$.

Al querer retratarme en un pedestal

coronada de laurel.

Mi noble amigo:

el delicado y generoso obsequio

conmovida agradezco; mas no quieras

verme subir al pedestal que me alzas,

con la vista inclinada y con la frente

por ti ceñida de laurel glorioso, 
teñida de rubor... no, amigo mío; pinta un árbol más bien, hojoso y fresco en vez de un pedestal, y a mí a su sombra sentada con un libro entre las manos y la frente inclinada suavemente sobre sus ricas páginas, leyendo con profunda atención; no me circundes de palomas, de laureles ni de rosas, sino de fresca y silenciosa grama; y en lugar de la espléndida corona pon simplemente en mis cabellos lisos una flor nada más, que más convienen a mi cabeza candorosa y pobre las flores que los lauros.

No me pintes más blanca ni más bella; píntame como soy, trigueña, joven, modesta y sin beldad; vísteme sólo de muselina blanca, que es el traje que a la tranquila sencillez de mi alma y a la escacez de la fortuna mía armoniza más bien...

$$
\text { Píntame en torno }
$$


un horizonte azul, un lago terso

y un sol poniente, cuyos rayos tibios

acaricien mi frente sosegada.

Píntame así, que el tiempo poderoso

pasará velozmente, como un día,

y después que esté muerta y olvidada,

a la sombra del árbol silencioso

con la frente inclinada

me hallarás estudiando todavía. (54-55)

Cintio Vitier, tan diferente a la crítica feminista de Salgado, trata de los siguientes versos:

[...] vísteme sólo

de muselina blanca, que es el traje

que a la tranquila sencillez de mi alma

y a la escacez de la fortuna mía

armoniza más bien [...]

Afirma Vitier:

Toda la blancura que venía acumulándose como substratum de la visión arcádica y bucólica + el intimismo romántico (Poey-Plácido-MilanésMendive-Zenea) estalla en Luisa como invasora inocencia y delicia. Blanco es su verso idílico, amoroso o doloroso; blancos son sus 
asuntos y visiones; blanco el traje ideal de su modestia [...] (209)

Aunque resulta axiomático el significado del color blanco en nuestra cultura, decidimos retomar la obra de schulman donde expone el simbolismo del blanco martiano: "pureza, castidad, perfección y belleza moral" (432). Es así cómo, hasta ahora, se ha visto la obra de Luisa Pérez de Zambrana, como una poesía blanca, casta, pura, moral. Y es la que aplica Cintio Vitier en la interpretación de los versos anteriores.

En un análisis más abarcador que el de tal exégesis, Salgado manifiesta otra visión sobre este autorretrato. Explica cómo Luisa Pérez, cuando responde "desarma -desenmarca [...]- la composición de su imagen, tal como la había concebido su amigo Antonio López, y la vuelve a armar de acuerdo a parámetros profundamente personales que responden a su propia visión" (211). Siguiendo la crítica feminista de Domna C. Stanton y Sidonie Smith, esta autora expone así: "la autobiografía y el autorretrato son géneros predominantemente masculinos" (211). Y expresa cómo la mujer, al no tener una vida pública, ha sido "conminada por la iglesia a guardar silencio" y limitada a aquellos géneros que eran mirados como propio de su sexo, "y marginados por el canon." ¿Qué era entonces considerado como propio de "el ángel del hogar"? 
Según Salgado, "las confesiones religiosas, la poesía sentimental, las cartas, el diario íntimo" (212). La ensayista nos descubre que este texto pertenece al género epistolar, "femenino por excelencia y, por consiguiente, no amenazador" (214). Ya desde el título, que Salgado cree de "engañosa sencillez," señala, "puede leerse como la envoltura metafórica que establece el yo y el tú históricos al presentar al que le sugirió la postura que debía adoptar y que dio pie a su respuesta" (214). Salgado analiza entonces cómo en los primeros veinticinco versos, se dedica Luisa Pérez "a borrar la falsa imagen, impuesta de fuera, y a remplazarla con otra, que considera más a tono con su arte, su carácter y sus circunstancias vitales" (214). Luego pasa a examinar la segunda estrofa que es donde aparece la blancura analizada por Cintio Vitier. Continúa y dice que es allí donde: "la voz poética pasa a corregir la imagen que le fue dada a imponer el entorno que debe enmarcar la postura femenina, estética y vital con la que prefiere retratarse" (214). Evita, con unos subterfugios, tener una postura como la de la Avellaneda, que Salgado llama "ostentosa (beligerante)" (214).

Cree Salgado que "[d]esde el punto de vista de la escritura femenina su estrategia tuvo éxito" (214). Un éxito que ha durado hasta nuestros días y que logra engañar hasta a 
los experimentados ojos de Cintio Vitier, a quien se le escapan estos significados que muestran a la verdadera Luisa Pérez de Zambrana detrás de un poema que hasta ahora nadie ha criticado, esa mujer que sobresale en "Contestación." Este autorretrato "disfrazado de inofensiva carta," continúa Salgado, "afirma inequívocamente su original individualidad sin necesidad de adoptar una postura feminista que ofendiese a la sique masculina" (215) .

Nos extendemos en estas observaciones, porque hasta ahora, al leer a Luisa Pérez de Zambrana, casi la totalidad de los críticos no han tenido la sagacidad de ver a la otra, la que inteligentemente resalta desde las profundidades del poema, la que sin buscarse problemas con el statu quo, no dejó de imponer su pensamiento y su otredad. Pérez de Zambrana, en este valioso estudio, al rechazar la imagen de Antonio López, va más allá de lo que en su tiempo se esperaba de una mujer, porque según afirma Salgado:

[l]a imagen «en un pedestal/coronada de laurel» reproducía un gesto trillado y ostentoso sin traza de individualidad: la imagen retórica de la poeta en sus laureles omitía cualquier apecto humano o artístico de su persona histórica [...] Al superponer ambas imágenes crea el interesante efecto 
de un palimpsesto que permite leer simultáneamente lo que Pérez cree ser (una mujer segura de sí misma) y lo que no quiere ser (un objeto del deseo masculino) $\cdot(215)$

Ampliamos el examen minuicioso de este retrato con salgado, quien demuestra cómo Luisa Pérez de Zambrana "rehusando terminantemente (con dos negativos) adoptar la falsa postura de humildad que se le impone" (316), dice:

$$
\text { [...] no quieras }
$$

verme subir al pedestal que me alzas, con la vista inclinada y con la frente por ti ceñida de laurel glorioso, teñida de rubor... no, amigo mío; (54)

Resulta iluminador, para conocer a la real Luisa Pérez de Zambrana, los comentarios que Salgado hace al respecto: La estampa de pasiva cosificación sugerida por el amigo es borrada a continuación a favor de otra. Explica, que en vez de exhibirse en un pedestal, prefiere sentarse bajo un árbol [...] a leer un libro "con profunda atención." Las dos imágenes que Pérez baraja aquí indican dos visiones genéricas antagónicas. La masculina de López coloca a la mujer en un pedestal; la hace el objeto inaccesible del 
mirar y del deseo del varón. La femenina de Pérez, por el contrario, inscribe a un sujeto: una mujer que sabe escoger su postura (destino) y guarda para sí misma la fuerza de su imaginación implícita en su cabeza inclinada (para evitar los ojos del observador), y en el libro que lee. (216)

Más allá de la etérea, pura, vaporosa, obediente y casta Luisa Pérez de Zambrana, que han visto la mayoría de los investigadores, se esconde la otra, la que se ha quejado ya de la situación esclava de la mujer de su época.

Representa un arcano determinar cómo se le ha escapado a la crítica una composición en donde Luisa Pérez de Zambrana expresó directamente, sin subterfugio alguno, su forma de libre pensar. Me refiero a su poema "Contestación," escrito dos años antes del anterior, es decir a los veinte años. Tiene un pie de página, en la Antología poética, que señala: enero de 1855; especifica Chaple, en sus valiosas "Notas a los poemas," que fue el día 11. Tuvo inicialmente el título "Contestación a un amigo," y con numerosas variantes se publicó en su primer libro. Un texto que sólo apareció en esa edición y el cual su autora eliminó temprano, muy seguramente por las razones ya expuestas, expresadas por Max Henríquez 
Ureña. Como en el poema anterior, toma forma de carta y es una obra que responde a una sugerencia de otra voz masculina.

La primera estrofa, que consta de once versos, muestra lo que su amigo -Manuel Borges Navarro ${ }^{52}$ - quiere de ella y la respuesta inteligente de Pérez de Zambrana, donde no falta la velada ironía:

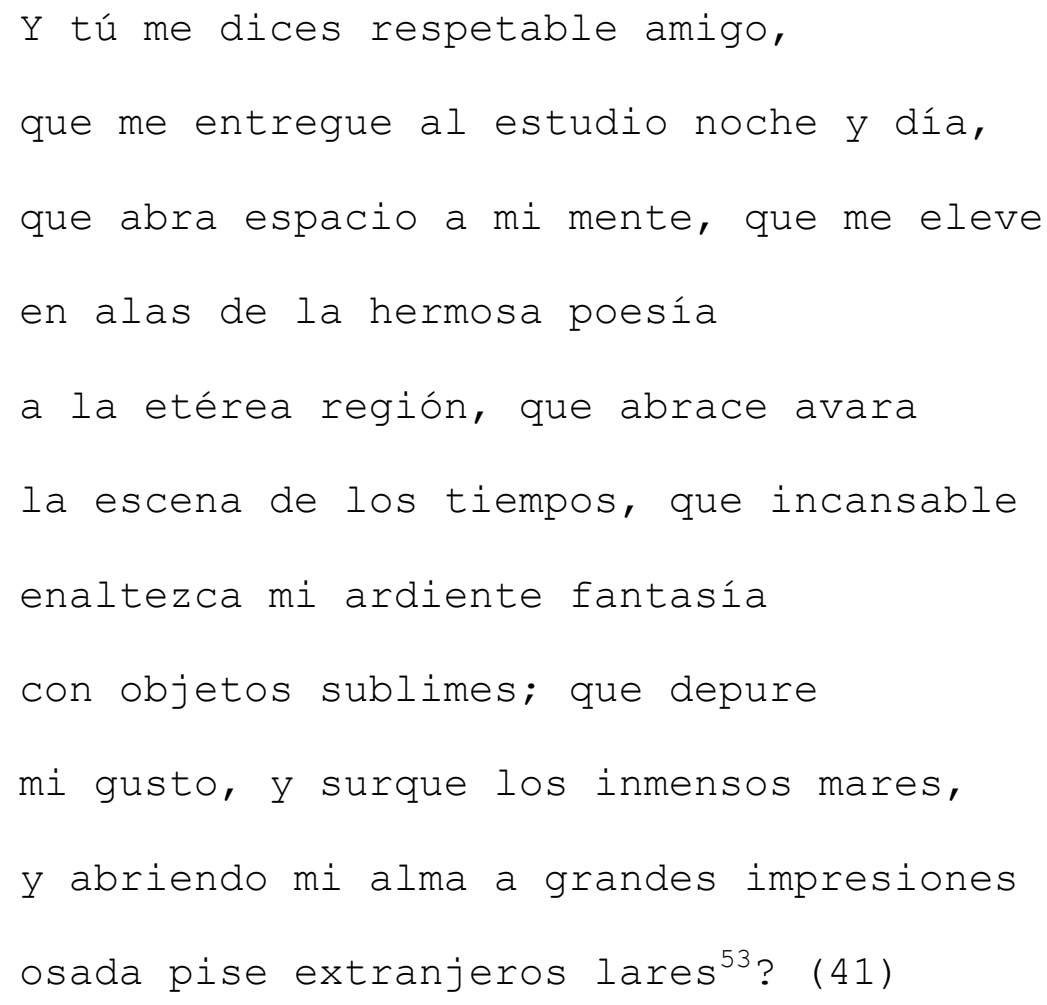

La segunda estrofa posee un verso más que la anterior. En los tres primeros versos concluye Pérez de Zambrana los consejos que le ha dado el amigo. Nótese además su lamento. El aparentemente simple "ay," es una leve muestra de la queja profunda que guardó durante su larga existencia:

Luego llevado de tu afecto dices 
que recompensa de mi afán un día

venturosa obtendré... más iay! amigo [...]

Es decir, que Borges Navarro advirtió inmediatamente el genio de la autora y, basado en su amistad, la aconsejaba. En las últimas palabras de este verso continúa la respuesta. Realmente el comienzo está en la ironía que yace en la estrofa anterior. En estos prosigue la queja:

[... más iay! amigo

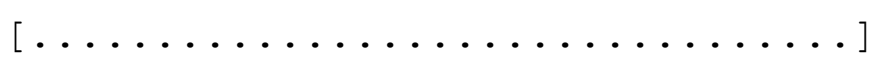

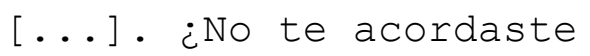

al invitarme a recorrer naciones,

que en el mundo impacable y malicioso

mujer, huérfana y joven nada puedo? (41)

Resulta evidente que la poeta tenía plena conciencia de la sociedad patriarcal donde vivía y del papel que se le otorgaba como mujer, pues esta composición en la cual describe el mundo como "impacable y malicioso," se publicó solamente en el primer poemario, como hemos dicho anteriormente. Luisa Pérez de Zambrana con este poema borra, en parte, la visión idílica que sus críticos le han querido imponer. Ese mundo que después idealizó fue el refugio de la poeta, pero no el universo de su pensamiento. No podemos olvidar que en una de sus más celebradas composiciones, -a tal punto de aparecer 
entre las "Cien mejores poesías cubanas" de Rafael Esténger en 1948-, "La melancolía," publicada originalmente en Cuba poética, en 1859, es decir, cuatro años después de la obra que ahora analizamos, Luisa Pérez escribe:

$$
\begin{aligned}
& \text { Yo soy la virgen que en el rostro lleva } \\
& \text { la sombra de un pesar indefinible; } \\
& \text { yo soy la virgen pálida y sensible } \\
& \text { que siempre amó el dolor. (61) }
\end{aligned}
$$

En este texto la autora, en la sociedad apegada a la religión propia de su tiempo, especialmente católica, utiliza la frase "virgen pálida y sensible/ que siempre amó el dolor" (61), para describirse. Sin embargo, nos ha dicho, en el mismo párrafo, que esconde un pesar indefinible. ¿A qué pesar se refiere? ¿Será al manifestado en "Contestación," único trabajo donde directamente se rebela y afirma en respuesta a un amigo que la invita a que estudie, a que abra su mente, a que visite el extranjero, etc.,? En ese momento la poeta lleva un año de casada, un matrimonio que todos los biógrafos y estudiosos dicen que fue feliz, aún no ha sufrido las numerosas muertes que le harán escribir sus tan celebradas elegías. ¿Qué pena guarda? Ya no está sola; en su juventud la acompaña un médico culto, escritor y enamorado. Entonces, ¿no sería su condición de mujer? ¿Por qué no volvió a publicar su "Contestación"? 
¿Prefirió soportar sin volver nunca más a quejarse abiertamente, ya que anuncia que "siempre amó el dolor" en esta estrofa? ¿Estaría la respuesta a esta pregunta en los versos que siguen de "Contestación"?

¡Oh y si supieras como mi alma ardiente

de emoción palpitante se recrea

con la embriagante y seductora idea

de ver abrirse las turgentes velas,

flotar el lino, levantarse el ancla,

crujir la quilla y como el viento raudo

volar meciéndose en bajel sereno

sobre la azul inmensidad...! ¡Dios mío!

Qué suprema ventura! ¡Y yo no puedo

tanta dicha gozar...! ¡Oh! cuál extingue,

cuál consume mi vida ese deseo

eterno, ardiente, inextinguible...! oh cielo!

Arranca, arranca por piedad del alma

esa ilusión irrealizable y loca,

esa idea tenaz que me arrebata

la dulce paz que disfrutar ansío! (41-42)

Los versos anteriores constatan con cuanta vehemencia

Luisa Pérez de Zambrana sueña ser libre y andar por el mundo, algo que ella llama "suprema ventura" que no puede "tanta 
dicha gozar." Un deseo tan fuerte que la consume, que tiene que pedir a las alturas que le arranque "por piedad del alma esa ilusión irrealizable [...] esa idea tenaz que [le] arrebata la dulce paz que disfrutar ansí[a]" (42). En definitiva el deseo de gozar de libertad como la que sí poseían los hombres de su época, una idea que al confrontarla con su tiempo tiene que concientizar como "irrealizable y loca." Ofrecen estas vigorosas y fuertes palabras una idea muy distinta de las que dan Martí, Cintio Vitier y otros críticos y que, en su robustez, recuerdan precisamente a las de Gertrudis Gómez de Avellaneda con quien se le ha comparado para diferenciarla. Llevar a cabo este pensamiento de Luisa Pérez de Zambrana sólo le estaba permitido en su siglo al hombre. Sergio Chaple afirma al respecto:

en «Contestación», poema impregnado, en oposición a otros de esta etapa, del coloquialismo fascinante que hace hoy parecernos tan cercana a nuestra sensibilidad su poesía, hallamos estos versos en los cuales su protesta ante la situación de inferioridad social de la mujer asume de antemano la postura obedientemente resignada con que encararía su trágico destino posterior. (17) 
En la próxima estrofa, luego de haber expresado su opinión continúa la poeta:

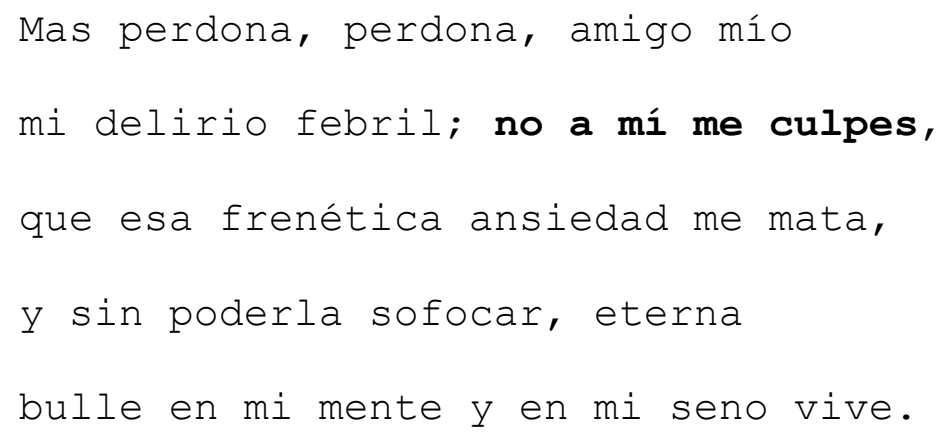




\section{¡Cuántas veces lloré con amargura}

costumbre tan fatal...! (42), (énfasis nuestro)

Luisa Pérez de Zambrana tiene plena conciencia de su situación, se denomina esclava, cuando aún existía la esclavitud negra en Cuba. A ellos se iguala y dice que ese estado ocurre por el hecho de ser mujer. Decide callar su protesta hasta el final de sus días, como sabemos, pues no volvió a escribir textos de este tipo. ¿Será por eso que dice ser la virgen que "lleva/la sombra de un pesar indefinible/ [...] la virgen pálida y sensible/que siempre amó el dolor[?] (61). Como veremos, en "Contestación" se repite un verso, que itera, al final, con el que cierra el poema. La poeta se da cuenta de sus limitaciones. Calló sí, pero con un silencio perspicaz, sabio, pues en este texto muestra que poseía un juicio ético que le permitió discernir perfectamente entre el bien y el mal social que catalogó como "costumbre tan fatal":

Mi buen amigo,

ya sabes cuánto se me opone, y cuánto

yo lucho por vencer...! oh! no te ofendas

si a tu afectuosa invitación no cedo,

pues tu bien sabes que en el mundo injusto

mujer, huérfana y joven nada puedo. (42) 
La única diferencia entre la primera vez que dice este verso y la segunda es que, en la primera aparece como una pregunta al amigo. En la segunda, es la respuesta o actitud de resignación, quizás de abandono, de esta lucha que ella veía como imposible. No conocemos ningún otro trabajo posterior a éste donde se manifieste esta idea, al menos como la expuso aquí.

Hay otro poema que se debe tener en cuenta. Apareció, según nota de Chaple, el 27 de diciembre de 1880, en el Diario de las señoras. Se nombra "Poesía esclava," y está dedicado a otra creadora y luchadora por la mujer: Aurelia Castillo. Este texto, de carácter aparentemente metapoético, está compuesto de doce versos divididos en estrofas de tres. En el segundo de ellos, se pinta a la poesía como "un ángel celestial que lleva atadas sus manos de marfil" (69). Dentro de la Cuba, eminentemente católica, la imagen resulta grotesca, aunque supo Luisa Pérez de Zambrana disimularla colocando en su vecindad adjetivos diáfanos (estrelladas y celestial). La composición, en forma de diálogo, puede ser interpretada como una conversación entre la autora y su imagen, reflejada como en un espejo, que en este caso representa su otredad poética. Es decir, que de quien habla Luisa Pérez de Zambrana no es de la poesía sino de ella misma. El símbolo del ángel atado es 
una figura que viene muy bien con la de "ángel del hogar" que en su siglo se daba a la mujer familiar. Las estrofas finales de "Poesía esclava" son las que siguen:

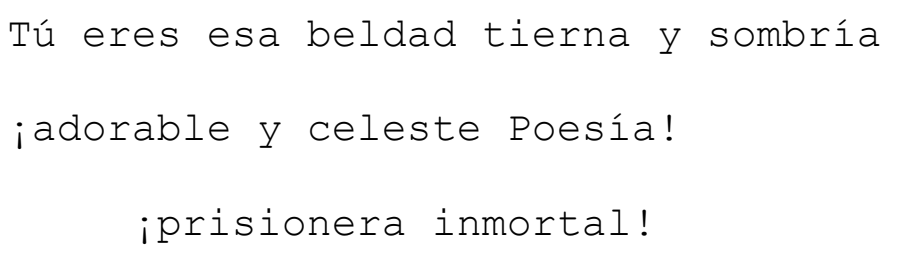

Los dos últimos versos, supuestamente, son las palabras de la otredad poética de Luisa Pérez de Zambrana, las de la autora, no la material. Si volvemos sobre "Contestación," vemos que allí su creadora ha pedido ya que no se le culpe. Con ese antecedente, puede afirmarse que, en este caso, Luisa Pérez habla realmente con su imagen en el espejo, es decir, la mujer con su identidad poética. La Luisa Pérez de Zambrana física, es la que pregunta; la respuesta, es de la poeta que decidió "llevar la libertad" por ser una "prisionera inmortal." Mirta Yañez en "El discurso femenino finisecular en Cuba: Aurelia del Castillo y otras voces en torno al 9854," se refiere a ella como "la muy mansa Luisa Pérez" (26) . Quizás sería mejor nombrarla como tan bien lo hace salgado: "la 
bíblica mujer fuerte que había de ser andando el tiempo" (216). Si comparamos su actitud ante la vida, su resistencia ante la adversidad, a la muerte de su esposo y de sus cinco hijos, a la de su hermana Julia Pérez Montes de Oca, poeta también, así como la de entrañables amigas autoras como ella, a cuyas muertes dedica varios textos; si Luisa Pérez, con su profunda sensibilidad, sobrevive lo anterior, y a la pobreza y el olvido de la etapa final de su larga vida que alcanzó los 87 años, sin dejar de crear, gracias a lo cual tenemos las más grandes elegías escritas en Cuba, no es precisamente débil la imagen que viene a la mente, sino la de una roca solitaria que persiste y pervive a toda las inclemencias de su tiempo.

Si comparamos esa experiencia con la Gertrudis Gómez de Avellaneda en la carta al Marqués de Alcañices, en la última etapa de su vida, donde expresa que está "[r]esuelta á abandonar la poesía [...], la pasion de mis primeros años juveniles, pero que se asocia mal con los pesares que despues he sufrido ${ }^{5}$," aun la figura fuerte de la Avellaneda se achica ante la imagen estoica de Luisa Pérez frente a la tumba de sus seres amados y ante la negligencia social. Si sabemos que la Avellaneda vivió prácticamente treinta años menos que Luisa Pérez: ¿quién puede negar la fortaleza que mantuvo a ésta ante la debilidad final de aquélla con quien se le comparó? Luisa 
Pérez de Zambrana resistió hasta los 85 años cuando volvió a revisar su obra para editarla. Su vida, ¿acaso no es una negación de aquellos que la vieron como un ser débil? Podría aplicársele a ella misma el último terceto de su "Soneto en la coronación de la Avellaneda," que leyera en el teatro Tacón la noche del 27 de enero de 1860, versos donde la compara con hombres célebres; otra prueba de que en su mente esta desigualdad tenía un lugar importante a la que se oponía desde su lírica. Una vez más la otredad de Luisa Pérez se manifiesta igualando los dos sexos poéticos:

Pues si tú no eres grande ;oh genio augusto!

Tampoco fueron grandes en la tierra

Byron, Racine y Calderón y Homero. (Álzaga 133)

Es interesante mencionar que aunque la mayoría de los críticos sitúan a Luisa Pérez dentro del período romántico, varios han asegurado que en algún momento sus textos "sugieren acentos modernistas" (Gutiérrez-Vega 197), o que "es preciso señalar también que su poética denota la incipiente huella de la distintivamente individualizadora sensibilidad modernista" (Salgado 215). La mayoría, entre ellos José Lezama Lima, afirma, sin embargo, que "[n]inguna de las escuelas literarias que se sucedieron a lo largo de su vida la conquistaron" (2: 181) . 
Concluimos este epígrafe con las palabras que sobre esta poeta expresa Salgado en su ya mencionado artículo: "Por desgracia, la experiencia femenina nunca se ha considerado digna de figurar entre los grandes temas del canon literario. Así, y a pesar de su obvio valor, la obra de Luisa Pérez, como la de tantas otras mujeres, ha ido cayendo en el olvido" $(216)$

\section{Julia Pérez y Montes de Oca.}

La hermana menor de Luisa Pérez de Zambrana nació el 11 de abril de $1839^{56}$ en igual sitio que ésta: finca Melgarejo, el Cobre, Oriente. Murió el $25^{57}$ de septiembre de $1875^{58}$ (Rocasolano 96), en Artemisa, Pinar del Río. Junto a su hermana Luisa Pérez de Zambrana y a Gertrudis Gómez de Avellaneda, es de las poquísimas mujeres que se nombran cuando se cita y se analiza este período. Es lo que hacen Lezama Lima y Cintio Vitier, los más conocidos antólogos cubanos. Julia Pérez, por ejemplo, es una de las tres poetas que aparece entre Los grandes románticos cubanos de este último que, obviamente, son las que encabezan este párrafo. Alberto Rocasolano, es uno de los pocos críticos que, por excepción, se dedica a otras autoras, como hemos venido observando. 
Julia Pérez Montes de Oca escribió muy poco y sólo apareció un libro suyo póstumamente, doce años después de su óbito, en Barcelona en 1887. Su título fue Poesías; y se debió al celo de Domingo Figarola y Caneda, quien la incluyó en la Biblioteca de «La Ilustración Cubana». Por la "Advertencia" (3) que aparece en este poemario la obra puede "considerarse completa" ya que ayudaron al recopilador Luisa Pérez de Zambrana y el Sr. Néstor Martínez, primo de Julia Pérez. Están recogidos allí, además de los textos que esta autora había dado a la publicidad, una sección que se llama "Poesías inéditas." Posteriormente se han publicado sus Poesías completas, en La Habana, en 1957 y en 1981. Ésta última, bajo el nombre de Poesía, con prólogo y notas de Octavio Smith.

A la muerte del padre, Julia Pérez Montes de Oca también se instaló en Santiago de Cuba en unión del resto de la familia. A instancias de Luisa Pérez, viaja con ella a La Habana en 1858, donde participa en las "Noches Literarias," la tertulia que semanalmente, todos los jueves, se llevaba a cabo en casa de Nicolás Azcárate. Agrega Rocasolano que allí Julia tomó parte como actriz en algunas representaciones teatrales. Azcárate la incluye en sus históricos tomos con siete textos -uno más que a Luisa Pérez, dos más que a María de Santa Cruz y cinco más que a Mercedes Valdés Mendoza-. Estos son: "La 
Espera," "A mi cítara," "A un lago," "El Genio," "A mi amigo Nicolás Azcárate," "A un arroyo seco59," y "La Tarde." Poemas que, salvo éste último, no se toman por sus antólogos, aunque Rocasolano también cita "La espera."

Julia Pérez y Montes de Oca colaboró en diversas publicaciones: en Santiago de Cuba con El Redactor; en La Habana con El Kaleidoscopio (1859), El Siglo, que dirigía el conde de Pozos Dulces, La revista de La Habana, El Album de La Habana y El Album Cubano de lo Bueno y de lo Bello (1860); en Cádiz, España, con La Moda Ilustrada.

José Martí, en "Tres libros. Poetisas americanas," dijo de "La Tarde" que era "una muy bella oda" (138). Manuela Herrera narra cómo "[e]n 1863 obtuvo una verdadera ovación en el Liceo de Guanabacoa, con la lectura de su poesía "A un arroyo seco" (N. pág.). Max Henríquez Ureña, por su lado, le encuentra "facultades poco comunes para la poesía" (1: 318). Según Lezama Lima, Julia Pérez "[tenía] un regusto por la lectura de los clásicos" (2: 208), y agrega que supo "mantener un equilibrio exquisito entre el sentimiento y la forma (2: 208). Al compararla con su hermana, añade que ambas "son poetisas dolorosas," pero que Luisa amaba lo adquirido y perdido mientras que Julia amaba, "por el contrario, lo que nunca pudo ser suyo, aquello que tuvo con ella un roce 
engañador, un amor imposible con uno de los poetas de la época, todo lo que dejó en su vida una cicatriz de la que nunca pudo recuperarse" (2: 208). Es sabido que durante sus últimos días Julia Pérez se apartó totalmente de la sociedad y que la embargó una gran melancolía. Max Henríquez Ureña afirma que se alejó del mundo, que vivió aislada y que "[n]adie supo con precisión, ni aun sus propios hermanos[,] cuáles fueron las causas de[1] brote de pesimismo que ensombreció la etapa final de su vida" (1: 319). Respuesta que parece estar en palabras de Rocasolano "[por] la amargura de la enfermedad que minó sus pulmones" (96) y que el propio Henríquez Ureña diagnostica: "tuberculosis" (319). Sea cual fuere el motivo, es uno de los rasgos predominantes, más bien característicos, de su poética. Rasgo que señalamos porque la diferencia del resto de las autoras estudiadas.

Su poesía, al decir de Rocasolano, "se caracteriza por cierto bucolismo de impecable factura" (96). Realmente hay más, aunque éste es el escenario predominante donde su poética se desarrolla y actúa. Sus paisajes están cargados con todos los abalorios de la naturaleza: cielo, bosques, montañas, valles, ríos, aves, viento, tierra, aguaceros. Al mismo tiempo posee una tristeza de los afectos, presente en prácticamente toda su breve obra: llantos, penas dolientes, agonías, 
congojas, llorosos cantos, gemidos y dolores, recorren su lírica; sin olvidar su constante crítica a la sociedad urbana, el tema de lo marginado, que se itera, y los motivos fúnebres. A pesar del comentario de Max Henríquez Ureña, en el sentido que Julia Pérez Montes de Oca en La Habana, "fue objeto de señaladas deferencias en el mundo intelectual" (1: 309), escribió versos en los que habla mal de la ciudad, la que encuentra engañosa, y de la que quiere alejarse. Estos señalamientos urbanos se hallan en las composiciones leídas en las tertulias de Azcárate durante 1865, publicadas al año siguiente, y están recogidas en su libro póstumo. Desde "A mi cítara," poema que abre sus Poesías $^{60}$, se presenta de una forma constante su criterio sobre la sociedad. En este texto metapoético, compuesto por quince estrofas de cuatro versos cada una, la autora comienza invocando al "alivio de sus males [...] [la] melancólica cítara" (7). Luego se sumerge en la naturaleza y, desde ella, a partir de los dos últimos versos de la cuarta estrofa, encontramos la expresión de sus reflexiones sociales:

$$
\begin{aligned}
& {[\ldots \ldots \ldots \ldots \ldots \ldots \ldots \ldots \ldots} \\
& \text { De la sociedad huyamos } \\
& \text { Donde no llegue su vista. }
\end{aligned}
$$


De esa sociedad que vaga

Entre perfumes y cintas,

Emporio siendo del vicio

Y centro de la desdicha.

Y que en la mentida púrpura

De la trémula mejilla

Apenas ocultar puede

La palidez de la envidia. (7)

En las estrofas octava y novena compara la vida cercada por la naturaleza con la de la ciudad, y da la impresión de estar proyectando, al parecer, el maltrato recibido en el medio urbano. Hay que recordar que Julia Pérez pasó su infancia en el campo, rodeada de una hermana, célebre poeta, y de amigos, también creadores, entre ellos los hermanos García Copley de Santiago de Cuba y la holguinera Adelaida del Mármol; intelectuales provincianos con los que mantuvo excelentes relaciones. Su vida en la capital debe haberle sido difícil, al menos de eso da la impresión, al referir en las siguientes estrofas:

\footnotetext{
Ya el rumor del arroyuelo

Mi presencia solicita

Que tienen parte en sus aguas
} 
Algunas lágrimas mías.

Allí donde no ha llegado

En las alas de la brisa,

La inícua frase del odio

Ni el aguijón de la envidia. (8), (énfasis nuestro)

Con el distanciamiento que da el tiempo, nos cuestionamos: ¿Acaso como su hermana mayor fue famosa en su época, no querría, Julia Pérez, de un modo inconsciente o no, atraer hacía sí más atención que la que de todas formas gozaba? No lo sabremos ya pero su recriminación a la sociedad urbana es queja demasiado iterada. En "Abril," estando rodeada de campo, vuelve al mismo tema, cuando con sus versos expresa:

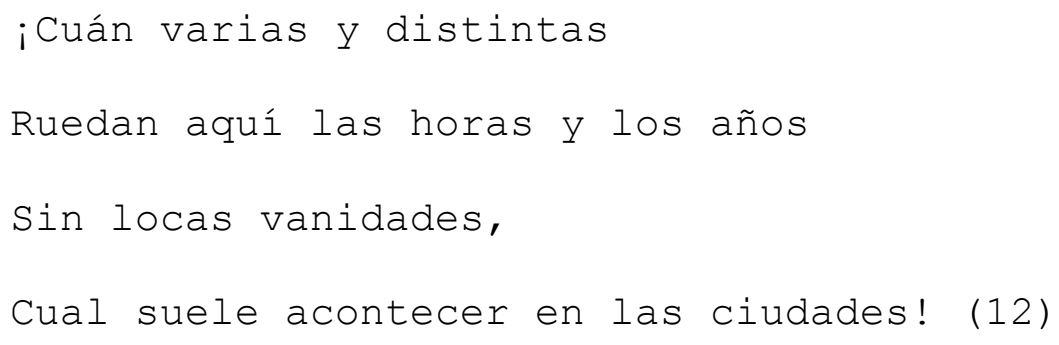
vertida sobre la ciudad, afirma:

$$
\text { [...] la fuente leda }
$$

Corre entre surcos de carmín y seda

Raudal de la cascada esplendorosa:

No está sobre una peña entristecido 
El pájaro desnudo de belleza

Fijando con enojos

Y empeño temerario

En otras aves de plumaje vario

Con torpe saña los lucientes ojos. (12-13)

Ideas que vuelven a repetirse en un "Soneto," cuyos dos primeros cuartetos afirman:

Se agita el hombre en la mundana vida

Mezquino y ambicioso y altanero;

Maligno el corazón, el labio artero,

Donde no tiene la verdad cabida.

En el encuentran fácil acogida

La envidia y el desden su compañero,

Y aunque el semblante muestre lisonjero

Su amor es falso y su virtud mentira. (40)

En "A un colibrí," se compara con un ave del campo, casi común denominador de las poetas del período romántico. Pero aquí Julia Pérez no hace como la Avellaneda ni como Adelaida del Mármol; es decir, no se proyecta en el pájaro enjaulado como una mujer esclava. Lo que leemos allí es una comparación entre la vida silvestre del animal, en la naturaleza, con la de ella en sociedad. "En el campo," vuelve a repetirse, en 
medio del canto a lo bucólico, su crítica social: "Y entre suspiros, esparce/Tus comprimidos dolores/Nacidos en las ciudades" (37)

La erudición que alcanzó está presente en varios poemas en los cuales muestra sus lecturas clásicas y francesas. Ejemplos de ello pueden verse en "A Víctor Hugo" (9-10); "La tarde" (25-26), donde introduce al poeta inglés Young (1683-1765); "El genio" (27-28), que toma motivos bíblicos -el Edén, Moisés, Israel- que mezcla con la Grecia antigua; habla de Atenas y de Homero y, más tarde, de Italia; lo elegíaco culto puede verse en el texto "En la muerte de Joaquín Lorenzo Luaces" (29-30), donde vuelven los temas bíblicos como el Nilo, y concluye con versos en que se mencionan, nuevamente, a los poetas helenos: "Al que llevó sobre su egregia frente/Los laureles de Píndaro y Homero" (30). Tiene un soneto a Robert Fulton (1765-1815), en el cual vierte su admiración por el norteamericano y cuyos últimos versos retornan al enfrentamiento de los genios con la sociedad: "Qué el eco del escarnio no le humilla,/Ni el grito del aplauso le envanece" (52). Interesante, resulta, que Julia Pérez y Montes de Oca no menciona, como sí otras escritoras románticas, ni a una sola mujer célebre. Todos sus héroes son masculinos, incluyendo a su omnipotente Dios del que trata en un trabajo donde expresa 
sus creencias. Esta religiosidad puede encontrarse también en "El genio." En "A Dios," uno de sus sonetos, los últimos tercetos versan:

$$
\begin{aligned}
& \text { En cuanto brota de la tierra inculta, } \\
& \text { En cuanto al aire ténue se levanta, } \\
& \text { En cuanto el mar en su interior sepulta. }
\end{aligned}
$$

$$
\begin{aligned}
& \text { En todo lo que aterra ó lo que encanta, } \\
& \text { Nunca, Señor, al hombre se le oculta } \\
& \text { La omnipotente huella de tu planta. (39) }
\end{aligned}
$$

El tema surge también en otros poemas como en "Meditaciones," texto del cual se conocen sólo fragmentos y cuyos últimos versos dicen: "Me pongo a meditar en la grandeza/Y la sublime magestad de Dios" (59).

"Al campo," considerado por Max Henríquez Ureña su mejor composición (319), demuestra cómo Julia Pérez disfruta, casi en éxtasis, la naturaleza en medio de la cual surge la catarsis emocional y melancólica. En los siguientes versos se observan estos elementos:

$$
\begin{aligned}
& \text { ¡Ay, que en la sombra de la triste noche } \\
& \text { Y al ténue susurrar de blandas hojas } \\
& \text { Despierta el corazón al sentimiento, } \\
& \text { y en trémulas congojas }
\end{aligned}
$$


Brota abundoso el llanto,

El alma exhala querelloso acento,

Y vuelan por las selvas con el viento

Los hondos ayes del sentido canto! (24)

En "A mi amigo Nicolás Azcárate," se manifiesta filosófica y reflexiona sobre la brevedad de la vida. Reflexiona también en "La tumba olvidada," texto del que sólo se conocen unos fragmentos, donde predomina el tema fúnebre, característico del período:

¡Oh vida de dolor, vida de llanto!

¡Oh sueño que caminas con la muerte,

Qué triste me pareces y mezquino!

¿Quién puede en tus abismos comprenderte,

Ni meditar en tí sin amargura?

Ay! tus flores sus pétalos abriendo,

Van sin cesar cayendo

Al fondo de insaciable sepultura. (57)

Fragmentos son también los del último texto de este poemario póstumo: "Desesperación," cuya primera estrofa da idea del estado final de Julia Pérez:

Tengo partida el alma en mil pedazos,

Estoy cansada ya de suspirar,

Y de mi llanto la abundosa fuente 
De tanto que ha llorado seca está. (63)

Los últimos cuatro versos de este poema inconcluso muestran el por qué de su título:

¡Oh tiempo, tiempo amargo de la vida!

Qué lento te deslizas para mí!

No me des á beber mas desengaños;

Corre veloz, que es hora de morir. (63)

Cintio Vitier en Lo cubano en la poesía afirma "[l]a mayor seguridad literaria en los versos de Julia, su metaforismo de evidente raíz clásica, el aplomo y la cadencia tradicional de su ritmo, no opacan, antes bien realzan y fortalecen el invasor encanto de sus contemplaciones y alabanzas, que constituyen, en los pocos poemas que escribió, uno de los momentos más altos de la poesía femenina" (221-222) del siglo diecinueve. Sin embargo, en su obra no se encuentra la queja feminista que vimos en su hermana. No hay un atisbo del papel de la mujer en la sociedad decimonónica, ni de sus luchas.

\section{Brígida Agüero.}

En su Parnaso cubano. Selectas composiciones poéticas, Valentín Riva Abreu menciona un segundo apellido, con el cual aparece también en la recopilación de González Curquejo: y 
Agüero. Nació el 12 de mayo de 1837, en Puerto Prícipe, hoy Camagüey, la misma ciudad de Gertrudis Gómez de Avellaneda, un año después de que ésta abandonara Cuba. Expiró el 26 de junio de 1865. Su muerte prematura - se expresa en Florilegio de escritoras cubanas- fue muy sentida, mereciendo, entre otros homenajes, una corona fúnebre poética que le consagraron los poetas cubanos (González Curquejo 2: 81).

Según Alberto Rocasolano, de niña vivió en una finca, cercana a su ciudad de nacimiento, con sus padres. De ellos aprendió las primeras letras. Era hija del poeta Francisco Agüero y Estrada de quien, dice González Curquejo, "heredó el amor a la poesía" (2: 81). Apenas se trata de ella en algunos estudios, pero en una carta de Gertrudis Gómez de Avellaneda donde habla de la creación literaria de su ciudad natal, la nombra como: "la niña Brígida Agüero, naciente estrella del feliz Camagüey" (cit. en Álzaga). Cuando sus progenitores se reinstalan en Puerto Prícipe da a conocer sus primeros poemas. En 1861 hizo estudios -clases de Literatura- en la Academia que sostenía la Sociedad Filarmónica de Camagüey de la cual llegó a ser socia de mérito. Por datos citados también en Poetisas Cubanas, de Rocasolano, conocemos que sus textos se encuentran dispersos en varias publicaciones de la época y que "algunos fueron insertados por José Manuel Carbonell en el 
tomo tercero de su Evolución de la cultura cubana61, 1608-1927 (La poesía lírica de Cuba62)" (88). Otros aparecieron en el segundo volumen de Florilegio de escritoras cubanas, de González Curquejo: "Las Artes y La Gloria" «A los socios del Liceo Camagüeyano», "Lo Bello," "La Fe Cristiana" «Dedicada á mi querido padre» y "Resignación." Riva Abreu en su prólogo de 1926 a su Parnaso cubano. Selectas composiciones poéticas publicado en Barcelona, dice: "Cuba ha dado también excelentes poetisas" (6) y la sitúa junto a la Avellaneda, a Luisa Pérez de Zambrana, a Aurelia Castillo y a Lola Rodríguez de Tió. En dicha selección de Riva aparece el texto "Lo Bello." Rocasolano explica: "[l]os escasos poemas que conocemos de esta malograda poetisa, revelan sensibilidad y delicadeza" (88). Éste, en sus Poetisas cubanas, sólo escogió "Resignación."

Este soneto empieza dirigiéndose a Dios y culmina con el último verso del poema "Plegaria a Dios," del también poeta romántico Gabriel de la Concepción Valdés, quien lo escribió poco antes de morir fusilado por conspirar en 1844: "Cúmplase en mí tu voluntad Dios mío." Pide Brígida Agüero allí, consciente de la enfermedad que la consumía, que se le mitigue su tristeza, y expresa la visión de su sombrío porvenir; hay en el final una aceptación de su estado que da título a esta 
composición. Muy diferente es el contexto de "Lo bello," tomado de González Curquejo (II: 87-88), donde, respondiendo a una pregunta que hace en el primer verso: ¿Qué es lo bello?, afirma que es lo equivalente a lo hermoso de la naturaleza. En ella predomina la quietud de lo bucólico americano. Pero además del "trino de la cándida avecilla," del "susurro del céfiro sutil," y del "suave murmurar de un arroyuelo," de la luz y de las flores del jardín patrio con su flora y su fauna, sitúa a las mujeres "hijas púdicas y bellas" y a los niños y a una madre tierna. Brillantemente, en siete versos, dentro del poema general, hay un poniente, sale la luna, y llega la noche. Pero más bello que Cuba, y el paradisíaco ambiente que acaba de describir, es "el sagrado esplendor de la virtud." Una virtud en cuyo seno se deleita epifánicamente. En "Las Artes y la Gloria," (González Curquejo II: 83-86) canta a la naturaleza cubana y, desde sus primeros versos, se pregunta: ¿Quién al ver de la aurora los destellos iluminando las tempranas flores, Bajo un cielo de fúlgidos colores Allí en los campos, de mi patria, bellos, No aspira a ser pintor de la Natura, Y bosquejar su espléndida hermosura? ¿Quién que escuche del índico sinsonte 
El melodioso, incomparable trino

En la espesura de encumbrado monte,

No siente de emoción arrebatada,

El sublime poder de la armonía? (83)

Luego da idea de su concepto de creadora, de sus deseos de alcanzar la fama, y de cómo debe ser vista por la sociedad.

Quizás en esos conceptos que esboza haya influenciado su visión del padre poeta, a quien dedica, amorosamente, un poema: "La Fe Cristiana." Sea por el motivo que fuere, Brígida continúa alzándose desde un discurso con el que aspira alcanzar una meta específica: "¿Quién habrá que resista/Al amor sacrosanto de la Gloria? (83) Más adelante, se refiere a la creación general y muestra la erudición que alcanzó cuando habla de Fidias, de Miguel Ángel, de Canova, de Praxisteles, de Velázquez, de Rivera, de Homero, de Tasso, de Milton, de Petrarca, de Racine, de Calderón y de Garcilaso. Continúa demostrando su amor y conocimientos de la ópera italiana: menciona a Donizetti y habla de su "Lucia di Lammermoor," de Bellini y de su "Norma," de la "Traviatta" de Verdi. En los últimos versos resaltan muchas de las características de la escuela romántica: la religiosidad, el patriotismo, en este poema que empieza con un canto a la naturaleza. Y llama la atención de los lectores -está dedicada a los socios del Liceo 
Camagüeyano- luego de hablar de Beatriz y de Laura, sobre la obra de las mujeres cubanas:

Y celebren los pueblos y naciones

La gracia y el candor de nuestras bellas.

Estudiad en sus obra la grandeza

Del Supremo Hacedor; tal en la vida

Es del artista la misión notoria,

Y haced que vuestro canto,

De patriotismo y de entusiasmo lleno,

Hasta el Empíreo suba

Con el nombre carísimo de Cuba. (86)

En la breve obra de Brígida no se encuentra ninguna queja de su situación de mujer.

\section{María de Santa Cruz.}

Nació en Matanzas y según Domitila García de Coronado en su Album Poético Fotográfico de Escritoras y Poetisas Cubanas, "en el partido de la Cidra." Su padre fue don Francisco Javier, hermano de la Condesa de Merlin, miembro de una de las más nobles y antiguas familias de Cuba. Su madre fue doña María del Carmen Figueras (García 151). Al inicio de su carrera literaria "ocultó su nombre bajo el anagrama de Amira" (García 153). No se sabe su fecha de nacimiento pero si que 
murió a los 80 años el 14 de febrero de 1923. Debió haber nacido pues en 1843 .

A las tertulias literarias de Nicolás Azcárate, donde se reunía la élite de la intelectualidad cubana de 1865, asistían cuatro mujeres, tres de las cuales se encuentran en esta investigación, son citadas por la mayoría de los críticos y aparecen en el Diccionario de la literatura cubana, editado en dos volúmenes, en La Habana -1980 y 1984-: Luisa Pérez de Zambrana, su hermana Julia Pérez Montes de Oca y, en menor grado, Mercedes Valdés Mendoza. Sólo una de ellas no figura. Esta cuarta mujer, poeta y narradora, es María de Santa Cruz. Cuando Azcárate publica su obra en dos tomos: Noches Literarias en casa de Nicolás Azcárate, escoge seis textos de Luisa, siete de Julia y dos de Mercedes. A María de Santa Cruz, le edita cinco. Pero en estos volúmenes no hay datos biográficos. Poco se sabe de su vida y de su quehacer literarios. García Coronado refiere que escribió dos cuentos: uno titulado "Un ramo de perlas" y otro de costumbres campestres cubanas (156), que pensamos que se trate de una novela suya titulada Historias campesinas, publicada en La Habana, en 1908. Novela que, Carlos M. Trelles, en su tomo quinto, menciona que se dio a la luz primeramente por la 
Imprenta El Iris en 1876, y afirma que se repartió por entregas de julio de 1876 a septiembre de 1877 (235) •

Se decide incluir en este estudio a esta escritora, que se codeó con la más alta intelectualidad habanera de entonces, para sacar del olvido sus poco conocidos trabajos creativos hechos a mediados del siglo XIX. Por González Curquejo, en su tomo II del Florilegio de escritoras cubanas -1913-, conocemos algunos datos. Aquí se encuentra sin el "de" que precede a Santa Cruz que sin embargo aparece en 1908, en la novela mencionada en el párrafo anterior. Se informa que era hija de los Condes de Mompox y de Jaruco (2: 275). Gracias a García de Coronado sabemos que era sobrina de María de las Mercedes Santa Cruz y Montalvo -la Condesa de Merlin (1789-1852)-. Y como existe la llamémosle coincidencia de llamarse María diacrónicamente elucubramos: ¿se lo pondría su padre, don Francisco Javier, en honor de su hermana? ¿Será por eso que el diccionario de la literatura cubana no la tiene en cuenta confundiéndola con la famosa tía de igual nombre y apellido? De este noble apellido Santa Cruz, dice Salvador Bueno, en su introducción a Viaje a la Habana, en datos a su vez tomados de Historia de familias cubanas, del conde de San Juan de Jaruco, La Habana, 1840: 
El apeliido Santa Cruz remontaba sus orígenes a los primeros siglos de las guerras llamadas de «reconquista» contra los moros. Procedía de Soria y su estandarte tremoló en la famosa batalla de Navas de Tolosa en 1212. Un descendiente de la familia, don Juan Beltrán de Santa Cruz, participó en la empresa de la conquista del Nuevo Mundo y la familia quedó instalada en Cuba desde los primeros tiempos de la colonización española. (7-8)

Sobre María de Santa Cruz afirma González Curquejo que era "[m]odesta como la violeta, ha sido enemiga de exteriorizarse y sólo a fuerza de ruegos consiguió Nicolás Azcárate que leyese algunas de sus composiciones en sus célebres «Noches Literarias» de Guanabacoa" (2: 275).

En orden cronológico publicó en Cuba Literaria, revista que existió entre 1861 y 1862, dirigida por José Fornaris y José Socorro León, poetas que después asistirían a las tertulias de Azcárate. En esta revista se encuentran los textos "A mi amigo José Fornaris contestando sus versos," "A mi padre," -con igual título escribió tres poemas. Las primeras palabras de éste son «La voz de mis hermanas uniéndose a mi acento»-que sale después, en 1865, en La

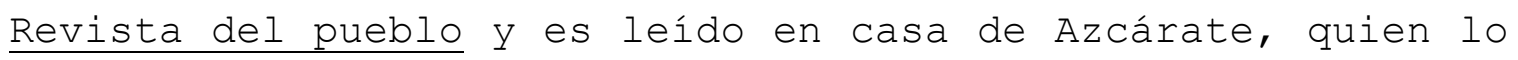


antologa, así como González Curquejo. Sale también en esta revista otro poema "A mi padre," que comienza "Rápidos pasan los fugaces años»; y "Adios á la Macagua," con una dedicatoria «A mi hermana Elena» -éste fue leído también en casa de Nicolás Azcárate, quien lo incluyó en sus libros. "Al primer aniversario del Liceo de Guanabacoa," sólo vio la luz aquí. La

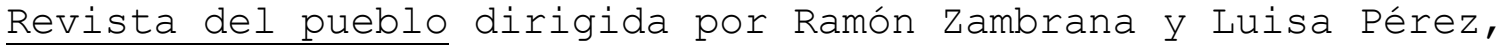
le publicó el poema "A mi padre" «la voz [...], del que ya hablamos, más "A un ciprés," -que puede leerse en las obras de Azcárate y en la recopilación de González Curquejo-. "Recuerdos de mi infancia," que tiene como dedicatoria «A mi hermana Manuela» -está entre los poemas escogido por Nicolás Azcárate-. González Curquejo menciona "El mendigo," que no aparece en ninguna de las antologías que la acogieron.

Por sus textos, en ocasiones narrativos, conocemos que amaba también su campo y lo prefería a la ciudad como describe en el prólogo de su novela. En su obra resaltan la naturaleza, lo patriótico, su tendencia melancólica, la preocupación por la marginalidad, su familia y los amigos. Al decir de García Coronado, en sus versos "no hay sino la queja sensible de su alma pura, las más santas efusiones de su filial cariño, y el amor hacia la virtud" (N. pág.) . 
Tal parece que proviene de una familia muy bien llevada. Es lo que sobresale en uno de los varios textos titulados "A mi padre," sólo antologado por González Curquejo:

$$
\begin{aligned}
& \text { ¿Qué sublime es el cuadro } \\
& \text { de una familia } \\
& \text { Que se ama inalterable } \\
& \text { Toda la vida! } \\
& \text { ¡Oh, padre mío! } \\
& \text { Que dulce es vivir siempre } \\
& \text { Todos unidos! (2: 287) }
\end{aligned}
$$

En otro "A mi padre," según García de Coronado su "primera composición poética" (150), líricamente más logrado leemos: La voz de mis hermanas uniéndose a mi acento, Te ofrecen, tierno padre, filial inspiración Verás en cada verso y en cada pensamiento La voz de nuestras almas, la voz del corazón. (2: 290)

En "A mi madre," expresa María de Santa Cruz el amor mediante comparaciones con elementos de la naturaleza:

$$
\begin{aligned}
& \text { ¿No ves en el prado ameno } \\
& \text { Languidecer una flor, } \\
& \text { Y cuando ya moribunda } \\
& \text { Se dobla, salir el sol }
\end{aligned}
$$




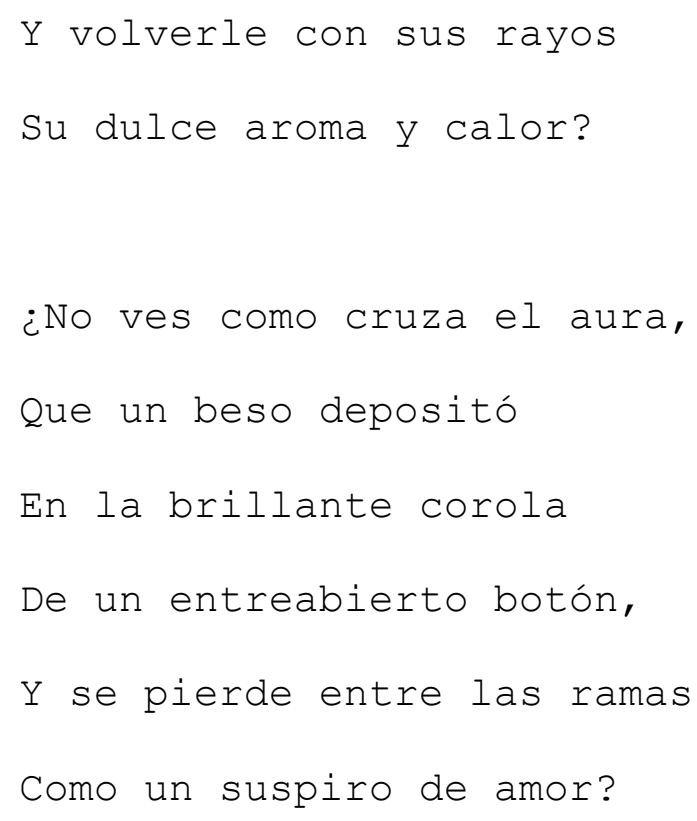

"A un ciprés," proyecta sus propios sentimientos en la naturaleza, en este caso en un árbol que asocia con los cementerios. Aprovecha para expresar, además, sus preocupaciones por la brevedad de la existencia: "Mira que la vida es corta/Mira que tal vez en breve/Lamentarás en la tumba 
(2: 282). Es típico del romanticismo que frecuenta, como aquí Santa Cruz, motivos fúnebres, en este caso asociados con la muerte temprana de un hermano:

Yo guardo desde la infancia

Memorias tristes y fieles,

Que están en el alma impresas;

Ni el tiempo borrarlas puede,

Que en mi corazón amante

En vez de borrarse crecen.

Yo tuve un hermano tierno,

Y vino la Parca aleve

A robarle a mi cariño [...] (2: 282)

Lo patriótico resalta en "A mi inolvidable amiguito Luis de Azcárate y Fésser," quien se iba a estudiar a Europa. Entre la citas a la naturaleza cubana resalta:

¿Podrá olvidar tu corazón amante

De Cuba las orillas florecientes?

¡Nunca!, una voz del interior responde:

Sople el Noto o el aura bonacible,

El hijo de los trópicos ardientes

Guarda siempre en el alma como un culto

El amor de sus patria intextinguible [...] (2: 284) 
En otros textos que encontramos en Nicolás Azcárate, vemos cómo a veces esta autora utiliza la forma del romance. Sucede en el "Adios a la Macagua," dedicado a su hermana Elena, donde se despide de lo que parece ser su lugar de nacimiento. Un fragmento de igual título fue recogido, por Samuel Feijóo, en El movimiento de los romances cubanos del

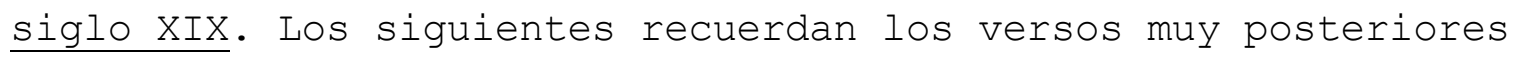
de Federico García Lorca:

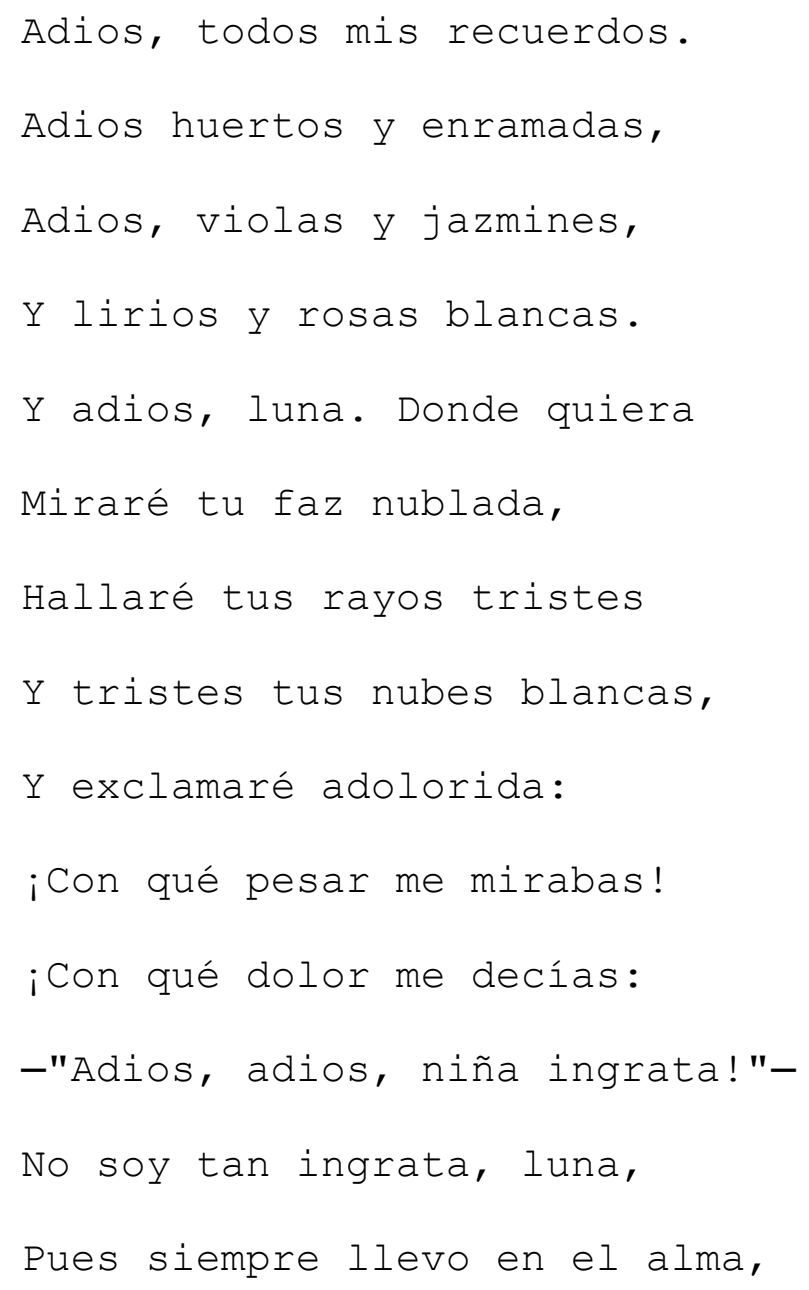




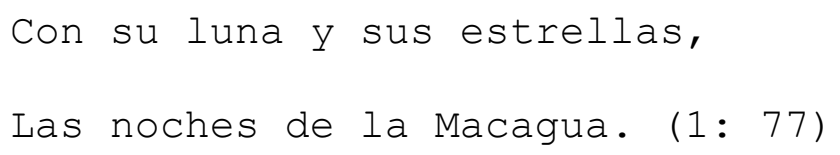

"Recuerdos de mi infancia," también recogido por Azcárate, romance dedicado a su hermana Manuela, además de mostrar el cariño a ésta, a quien tiene por una segunda madre, enseña unas fases afectivas, depresivas o melancólicas, que, al parecer, sufría María desde niña:

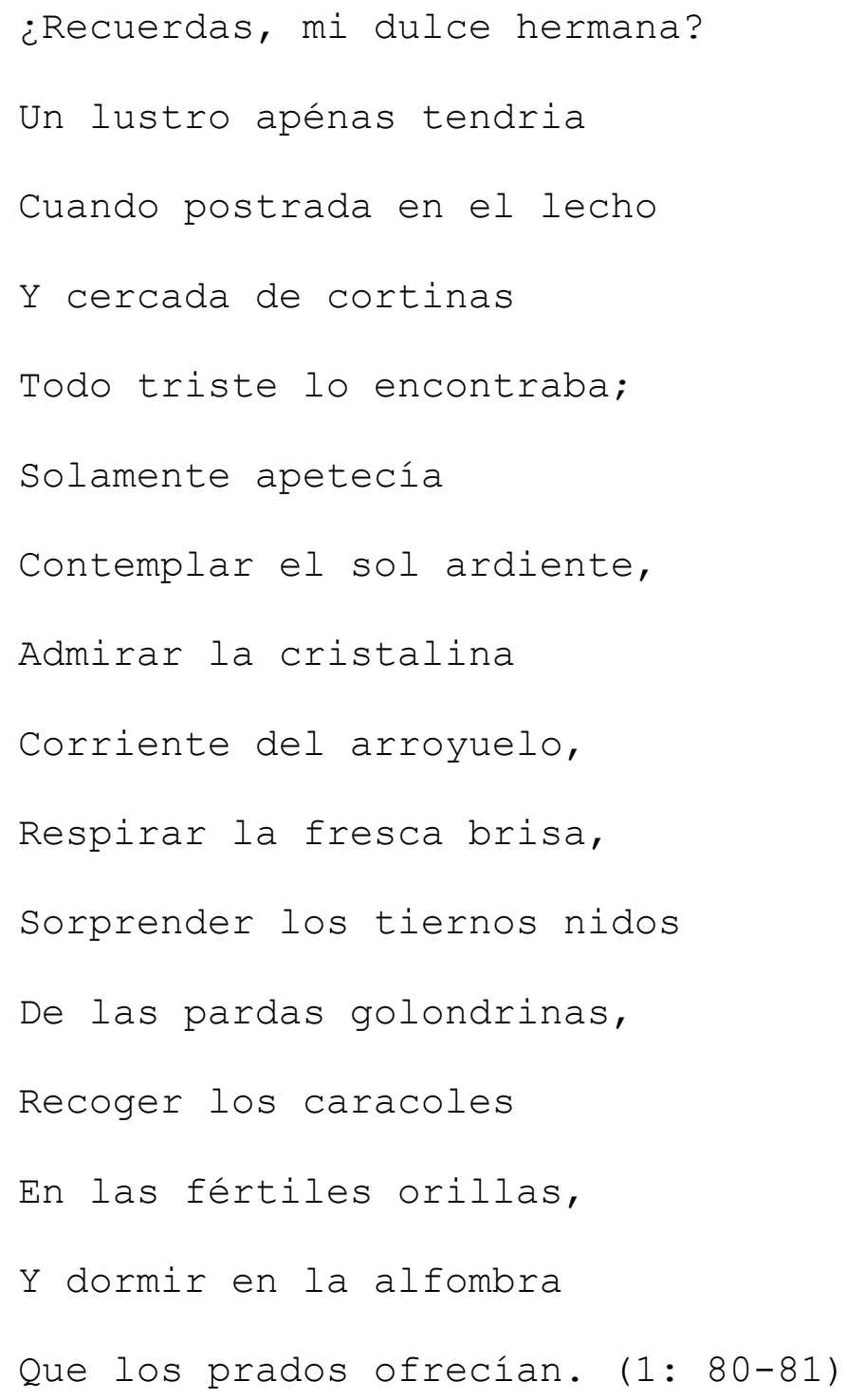


Luego, para afirmar que vivió uno de estos períodos, se extiende en la narración de sus recuerdos melancólicos infantiles y dice, en el mismo poema:

En aquella edad risueña

En que todo es alegría

Yo dejaba silenciosa

Mis amigos, mi familia:

Me ocultaba en los jardines

Solitaria y abatida,

y allí léjos del bullicio

Me olvidaba de mí misma,

Y libres correr dejaba

Mis lágrimas contenidas [...] (1: 84)

Afirma García Coronado: "[e]n los cantos de la dulce poetisa María de Santa Cruz no se deben buscar los acentos delirantes de la sublime Safo, la expresión severa y elocuente de Madama Stael, ni las vagas y sombrías imágenes de los de Ossiam" (N. pág.). A pesar de los pocos textos poéticos que publicó, en los que irradia la belleza y el cuidado de las formas, los cuales contienen los acentos del período; así como por su trabajo creativo en la época cuando comienza la expansión de la literatura femenina en Cuba, María de Santa Cruz debe por ello, en lo adelante, de tenerse más en cuenta. 
Quizás su timidez, citada por los pocos autores que la mencionan, haya tenido que ver con su casi inadvertido paso por el mundo de las letras cubanas; como dice, también García Coronado "no es la poetisa a quien el mundo alzará en su loor un himno de admiración, porque quizás ni aún conoce el eco suave de su voz" (N. pág.). A pesar de no haberse alzado en defensa de la mujer, nos parece que el hecho de haber participado con sus creaciones en casa de Azcárate, frente a hombres de la talla del sabio Felipe Poey, de José Fornaris, Joaquín Lorenzo Luaces, Rafael María de Mendive y Juan Clemente Zenea, además de haber publicado una novela, es más que suficiente para que figure en éste y en futuros estudios.

\section{Adelaida Benigna Mármol Ballagas.}

Nació en la Ciudad de Holguín el 10 de marzo de 1838. Casi todos los estudios erróneamente coinciden en señalar su nacimiento el 13 de febrero de 1840 (Cabrera N. pág.), equivocación que aparece incluso en el Diccionario de la literatura cubana (1980-84). Hija de Francisco Mármol Valdés, teniente de infantería retirado del ejército español y de Ana María Ballagas Guerra, también española. Murió el 16 de octubre de 1857, en Santiago de Cuba, de causas que se desconocen ${ }^{63}$. Aunque Francisco Calcagno, en su Diccionario de 
1878 afirma que falleció en 1859. Publicó Ecos de mi arpa en 1857, al parecer inencontrable (Rocasolano 90). El investigador David Cabrera Araújo determinó que, como "todos sus poemas aparecen publicados con el nombre de Adelaida del Mármol," (N. pág.), cuando la menciona respeta el deseo de la poeta. Decisión que respaldamos. Utilizó como seudónimo Delisa ${ }^{64}$.

Esta creadora, "fue la primera holguinera" que, a pesar de haber vivido solamente 19 años, "trascendió los límites comarcales y se hizo oír en toda Cuba" (Araújo N. pág.) y posteriormente fuera de ella. Juan J. Remos afirma en Proceso histórico de las letras cubanas: "a pesar de su corta producción puede estimársele como uno de los más positivos valores de la lírica romántica cubana" (127). Se debe a que fue, al decir del ensayista Alfredo Saínz Blanco, "una adolescente de cierta precocidad y temprana vocación literaria" (88), quien, según Cabrera, por diversas fuentes, es descrita como "una niña tímida, [...] débil, delgada, de constitución no muy alta y de tez blanca [...]. [...]. Blancura de su piel [que] constrastaba con sus ojos negros, dulces y apacibles. Tenía una voz [igualmente] dulce, trémula, casi imperceptible" (36) . 
Además de Cabrera, la sitúan en el período del romanticismo varios críticos, entre ellos Rocasolano y Cintio Vitier. Cabrera menciona los temas que la definen como una romántica de mediados de siglo XIX: el amor, el hogar, la paz, la naturaleza reinante, el paisaje cubano, las aves [...], las flores de su "jardín delicioso," la amistad sincera y la justeza del tratamiento a la mujer (18), así como "el empleo de un tono íntimo y suave" [...], y "[l]o subjetivo y la evasión hacia su propio mundo unido al yoísmo y al tratamiento del tema de la muerte" (40). Como hemos visto, se le sitúa en la segunda generación romántica (Rocasolano, también Cabrera). Movimiento literario que, encabezado por Luisa Pérez de Zambrana, Juan Clemente Zenea, Rafael María de Mendive y Joaquín Lorenzo Luaces, está compuesto por otras figuras de menos relevancia como Miguel Teurbe Tolón, José Joaquín Palma y los siboneístas José Fornaris y Juan Cristobal Nápoles Fajardo "El Cucalambé," así como el resto de las mujeres que hemos tratado en este apartado.

Adelaida del Mármol nació en el seno de una rica e importante familia holguinera que, como la gran mayoría de la población de origen español de la Isla, era católica. Su Partida de Bautismo, asentada en el libro de bautismos de 
blancos número 9, folio 309, número 2567, de la Catedral de San Isidoro de Holguín, la cita Cabrera Araújo:

Año del Señor de mil ochocientos treinta y ocho. En diez y ocho de marzo, Yo, el pbro. D. José Angel de Fuentes, Sacristán Mayor S.M. de esta Parroquial Mayor S.M. con beneplácito del Párroco, bauticé solemnemente a una niña de ocho días de nacida, a quien puso por nombre Adelaida Benigna, hija legítima del Tte. Don Francisco Mármol y D. Ana M. Vallagas ${ }^{65}$, abs. pats, el Tte. coronel D. Francisco Mármol y D. Josefa Valdés; Maternos. D. Pedro Nolasco Vallagas y D. Asunción Guerra. Padrinos D. Raymundo y D. Juana Mármol, a quienes advertí el parentesco espiritual contraído, y para que conste firmo. (99)

Su padre, a juzgar por Cabrera, tenía "cierta educación [...] y bienes de fortuna" (12), y, según consta en documentos de la época, dio libertad a más de uno de los niños nacidos esclavos en sus dominios; y su madre era, agrega el mismo investigador, "mujer de buenas costumbres y maneras, instruida y amante de la música y demás artes" (12), lo que influye en la educación y en las actividades culturales dentro del hogar. 
Los Mármol eran una familia importante dentro del núcleo de la ciudad ${ }^{66}$ que, por medio de Lorenza ${ }^{67}$, tía de Adelaida del Mármol, aparece emparentada con el Mayor General Calixto García ${ }^{68}$ (Holguín, 1839-Washington, 1898). Adelaida fue además prima hermana del Mayor General Donato Mármol ${ }^{69}$.

En un ambiente de militares retirados de la metrópoli ${ }^{70}$ -que se establecieron en la Isla luego de haber pertenecido a las tropas reales derrotadas por Simón Bolívar- y de futuros patriotas cubanos que después lucharían por la independencia de Cuba, se crió la poeta holguinera, la cual junto con sus hermanos -a saber tres: Emilio, Ana e Isabel María Caridad71-, fue educada en casa.

Al respaldar el movimiento encabezado por el gobernador de Oriente, general Manuel Lorenzo, en apoyo de la Constitución de 1812, Francisco y Raymundo Mármol fueron desterrados de Holguín (Rocasolano 90 y Cabrera 15-17), por orden de un Consejo de Guerra ${ }^{72}$ que hizo cumplir las órdenes de Miguel Tacón Rosique, capitán general de Cuba. Los hermanos habían sido acusados, en un anónimo, de "enemigos del trono" (cit. en Cabrera 17). Francisco, el padre de Adelaida del Mármol, es encarcelado y enviado a realizar trabajos forzados en las calles de La Habana, donde, según se cree, murió. Es por esta situación política que la familia se instala en la 
hacienda El Cristo, en la capitanía pedánea de Melagarejo, adonde fue enviado el tío Raymundo.

Luego de concluidos los primeros estudios impartidos por la madre, empieza Adelaida del Mármol un autodidactismo donde se mezclan la música, los idiomas y las bellas letras, entre otras disciplinas. Vive entonces en una región muy cercana a las hermanas poetas Luisa y Julia Pérez Montes de Oca, a las que conoce y con las que celebró veladas literarias. A éstas asistían los poetas Margarita Mármol, familiar de Adelaida, y Federico, Rafael y Balbina Copley. Es allí donde se pone en contacto con la obra de quienes la influenciaron: Heredia, Milanés, Plácido, Manuel de Zequeira, Luaces, pero sobre todo la de Sor Juana Inés de la Cruz y la de Luisa Pérez de Zambrana (Cabrera 19). Al conocer a ésta última -sólo dos y medio años mayor que ella, con doce-, escribió el soneto "Al conocer a Luisa Pérez." Texto en el cual se percibe el respeto hacia quien ya despuntaba en el ambiente cultural de Santiago de Cuba:

\author{
Trémula de placer, entusiasmada, \\ ansioso el corazón y palpitante \\ por admirarte, Luisa, yo anhelante \\ me dirigí gozosa a tu morada. (Cabrera 47)
}


Y concluye con el siguiente terceto que muestra lo importante que era para Adelaida del Mármol tal encuentro: "Yo cediendo a la voz del sentimiento/amarte juré, angelical cantora,/hasta exhalar mi postrimer aliento" (47). Luisa Pérez, a su vez, escribe para Adelaida del Mármol dos poemas al morir ésta. Constituyendo, uno de ellos, su primera elegía.

Cabrera en su libro describe al Melgarejo, que conocieron Adelaida del Mármol y sus amigos poetas, como un lugar prácticamente idílico de mediados del siglo XIX:

tiene al fondo las montañas de la Sierra del Cobre, atravesada por el arroyo homónimo de aguas cristalinas y arrullo acogedor, en sus márgenes crecían guirnaldas de flores silvestres entre los pinos susurrantes. Pobladas por miles de bellas aves que entregaban a cada instante el trino de su canto. El ambiente era claro, lleno de sol y alegría [...]. Esta alegría de la naturaleza con sus noches despejadas llenas de estrellas [...]. (22) Es éste el ambiente donde se desarrolla la poesía de tres poetas importantes del romanticismo cubano: las hermanas Luisa y Julia Pérez Montes de Oca y Adelaida del Mármol. Esta naturaleza se refleja, junto a la religiosidad, en "Dios," publicado en Semanario Cubano, en 1855: 
Y así del sol a los ardientes rayos

brotan los campos eternal verdura,

las flores lucen sus matices gayos

y radiante se muestra la natura,

me postro al contemplar tanta belleza

y de Dios reconozco la grandeza. (Cabrera 60)

Naturaleza cubana, que se convierte, como afirma Luis A. Jiménez en "dogma, una conquista estéticamente americana que supera la brutal apropiación del discurso eurocéntrico" (156). Posteriormente Adelaida del Mármol se trasladó a Santiago de Cuba. Allí, con sólo 15 años, el periódico local El Orden ya la contaba junto a otros como "cubanos distinguidos" (cit. en Cabrera 29). A los 16 es invitada, junto a Luisa Pérez de Zambrana y a Balbina García Copley, a formar parte en el cuerpo de redacción del periódico Semanario Cubano. La vida en Santiago muestra una muchacha activa que, a diferencia de las mujeres de su época, colabora en periódicos y revistas, anima tertulias literarias y realiza otras actividades de la Sociedad Filarmónica, en la cual se reunían, según Cabrera, los principales artistas y escritores. Por entonces, Santiago de Cuba era una de los centros culturales más importantes del país. En ese tiempo, Adelaida del Mármol era una joven que 
cultivaba la amistad. Lo expresa su poema "Recuerdo de mi infancia," dedicado «A mi amiga la Srta. doña Elisa Zapatero»: ¡Oh! Yo bendigo ese sublime afecto, celeste emanación de simpatía, pensamiento de Dios el más perfecto, mirada de María, pura amistad, del querubín sonrisa, que en deliciosa calma de las nuestras formó tan sólo un alma en nuestra infancia candorosa Elisa. (Cabrera 54-59) En los últimos versos de este texto se afianza el significado de tal afecto: "las dos, amiga mía/daremos culto a la deidad hermosa/que su luz derrama/y que en el mundo 'amistad' se llama." Esta composición apareció en Santiago en 1855, año cuando, en la capital cubana, Rafael María de Mendive, el maestro de José Martí, director de La Revista de La Habana, da a la luz otra de sus obras, "La rosa y la violeta," dedicada «A Matilde Despaigne.» En este poema alegórico, se habla de las flores del título rodeadas de otras, envidiosas de la gracia de la rosa. Ésta, amargada por tales sentimientos, baja la mirada y descubre a la violeta "pura y modesta beldad." Dice Adelaida del Mármol en una de sus últimas estrofas: "tú semejante a la rosa, Matilde brillas 
preciosa, por tu gracia virginal." La composición, tomada del estudio de Cabrera Araújo, concluye del siguiente modo:

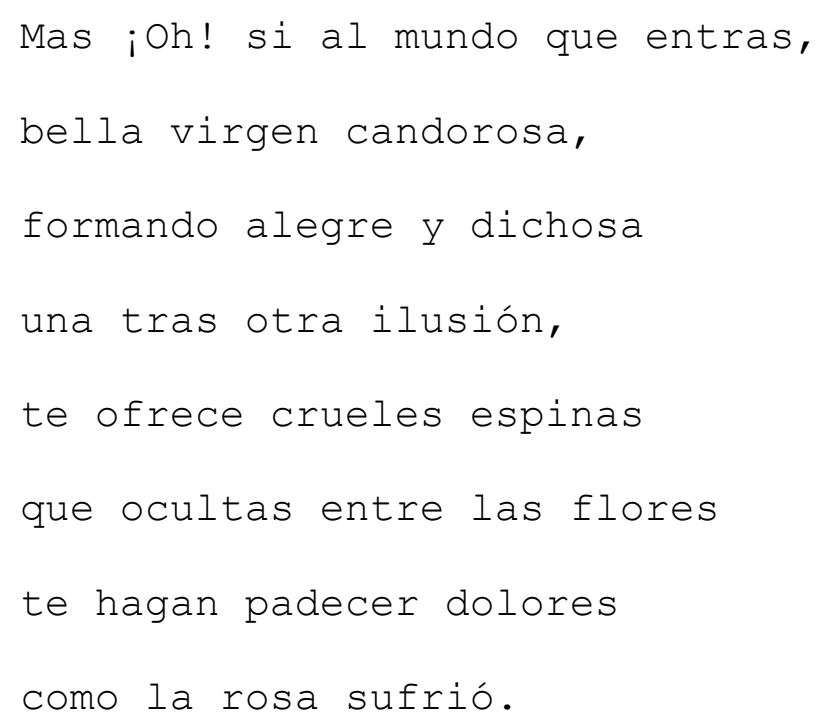

Jiménez cree que "[l]a rosa es símbolo de la pureza mientras que la violeta es emblema de la modestia, ambas cualidades siempre presente[s] en la escritura de la adolescente" (157). Pero el poema también demuestra que más allá de la placidez de 
esa existencia, proyectada por Adelaida del Mármol, hay una madurez, una profundidad de pensamiento, que recuerda a la muchacha cuyo padre ha sido encarcelado, desterrado y condenado a trabajos forzados en la capital del país, por lo cual su familia tuvo que alejarse de la ciudad donde había nacido.

Adelaida del Mármol sólo alcanzó los 19 años. No obstante tuvo tiempo suficiente para publicar un libro en el que reunió un buen número de composiciones donde, según el ensayista Alfredo Saínz Blanco, "se aprecia un dominio de los metros tradicionales y diversidad temática" (88). Llegó a ser tal este poder para la versificación que Cabrera expresa: "conocemos que en una reunión informal en la redacción de un periódico y a petición de los allí reunidos, improvisó un soneto que fue aprobado y aplaudido por los presentes, entre lo que se hallaban poetas de nombre" (38).

Consiguió, además, buen dominio de idiomas y tradujo una composición de Lord Byron "Jephtha's Daughter" Jephtha-, que según Rocasolano "fue [...] muy bien acogida [...]" (90), opinión hallada por Cabrera que cita a Fermín Peraza Sarausa, el cual encontró que Adelaida del Mármol "tenía mucha facilidad como traductora de poesía inglesa" (19). Dicha versión al español fue publicada en los 
principales periódicos de Cuba. Lo más interesante, en este poema de Byron, es que su contenido es altamente patriótico. Entre otros de sus textos se encuentran "La paz de nuestro hogar," "El jazmín de mi ventana" y "A mi jilguero." Sin embargo, a pesar de todo lo dicho hasta aquí, Araújo afirma que la vida y la obra de Adelaida del Mármol se mantuvieron silenciadas por más de un siglo.

Su poesía toma los motivos del período romántico que iremos desarrollando a continuación. De ella, Rocasolano afirma:

$$
\begin{aligned}
& \text { se desenvuelve en una atmósfera transparente y } \\
& \text { cándida, las sensaciones que le llegan de la } \\
& \text { naturaleza (flores y pájaros, a los que le otorga } \\
& \text { levedad simbólica como se advierte en «La rosa y la } \\
& \text { violeta», la amistad y la fe en Dios, constituyen } \\
& \text { motivaciones centrales en su brevísimo quehacer. En } \\
& \text { sus versos la naturaleza más bien parece surgir de } \\
& \text { los brillos y roces de la claridad lunar que del sol } \\
& \text { ardiente de la Isla. Es la suya una mirada inocente } \\
& \text { que quería hallar en la fragancia nocturna la } \\
& \text { sustancia real de la vida. (90) }
\end{aligned}
$$

El tema del jardín se repite en Adelaida del Mármol. Lo vemos en "Madrigal," poema dedicado a su sobrina Margarita74, 
del cual Cabrera opina "es la más débil de sus composiciones poéticas" (33). La primera estrofa, que pudo ser tomada de una realidad propia de la persona a quien está dirigida, habla de Margarita, la cual andando entre las flores del jardín, por arrancar una rosa, se hiere. De una forma alegórica advierte Adelaida del Mármol en la última estrofa:

En el jardín del mundo

donde hay flores que ocultan los abrojos, plegue a Dios, niña hermosa, que al querer admirarlas, si hay algunas de encantos a tus ojos, antes de ir a tomarlas, recuerdes las espinas de la rosa. (Cabrera 69)

Por su parte Luis A. Jiménez considera que es una "alusión edénica al mito entre Adán y Eva, y también al jardín cubano, tema iniciado por Adelaida, y poco estudiado en la historia literaria de nuestro país" (156). Más adelante Jiménez, profundiza en su interpretación y afirma que se trata de un "[d] iscurso parabólico por su contenido moral, y recordatorio importantísimo de esta voz femenina a la «preciosa Margarita» que no debe crecer bajo la ponzoña de la discordia, la manzana contaminada que aleja a la mujer del centro del discurso oficial" (157), lo que es discutible pues, como veremos, a la 
hora de ser directa, Adelaida del Mármol lo fue sin temores ni subterfugios.

En "El jardín de mi ventana," -que aparece también en La décima culta en Cuba, de Feijóo, y en el libro de CabreraAdelaida de Mármol muestra un tono melancólico, lúgubre, y motivos fúnebres y sepulcrales, frecuentes en el romanticismo, presagios de muerte que en ella, tempranamente, se cumplieron: Cuando descanse yo un día en la mansión solitaria, y se escuche una plegaria en torno a la tumba mía, bajo la lápida fría fin de esta existencia vana, do la vestidura humana para siempre allí reposa, que crezca sobre mi losa

el jazmín de mi ventana. (Rocasolano 93)

La vida en familia se observa en "La paz en nuestro hogar," exquisita composición que proyecta el medio en el cual se desarrolló y donde, como era costumbre de época, debía pasar la mujer la mayor parte de su tiempo pero que, en el caso de Adelaida del Mármol, sirvieron para el cultivo de su espíritu. Es un texto que refleja la formación moral y la 
posición social de Adelaida del Mármol, cuya madre gustaba de las artes y cuyo padre era hombre de noble espíritu:

No del mundo los fútiles placeres

en nuestro hogar imperan seductores,

ni el brillo, la ambición y los poderes

tienen ecos aquí halagadores,

empero en él existen nobles seres

que desdeñando el fausto y los loores,

sus horas de solaz y de alegría

consagran a la música y poesía. (Cabrera 67)

Por otro lado, hay que tener en cuenta el hogar donde se desarrolló Adelaida del Mármol. Allí florecieron las ideas independentistas de esta familia de importancia nacional, cuyo padre, aunque español, muere en la distancia encarcelado. Este dolor en una joven tan sensible e inteligente, que realiza su trayectoria por el mundo intelectual cubano, la llevan a expresar conceptos poco frecuentes hasta entonces en la lírica hispana

Su amor por la libertad lo manifiesta en la composición "A mi jilguero," donde canta a un ave enjaulada. Ave que recuerda la de Gertrudis Gómez en el poema de igual nombre "A mi jilguero", y en la cual, como hemos dicho en la Avellaneda, Kirpatrick cree encontrar una imagen en reflejo donde, el 
pájaro encerrado, es el de la autora (184), lo que también aplicamos a del Mármol:

Lindo jilguero inocente, entona tu dulce canto

y adivinarás el quebranto

que sufre mi corazón.

Mas, me miras con tristeza,

avecilla aprisionada [...] (Cabrera 78)

Estas ideas las continúa Adelaida del Mármol para expresar su opinión sobre la situación de las de su sexo en "Razones de una poetisa;" lo cual demuestra el grado de madurez y de conciencia que alcanzara. Rocasolano llama la atención sobre estas quintillas que publicó la holguinera y donde, según él, "se advierte un despertar ante la desigualdad social de la mujer y la cotidianidad de la poesía" (91). Quintillas sobre la cual Saínz Blanco afirma "[e]s sorprendente que en algunos versos aquella delicada y valerosa niña se pronunciara con energía contra el machismo colonial imperante en la isla" (88).

Por la importancia de estas quintillas, explicadas por más de un investigador, las citamos íntegramente. Aparecen, anónimas, en el libro de Ángel y Kate Flores: Poesía feminista del mundo hispánico (desde la edad media hasta la actualidad). 
Esta composición encierra la expresión de las luchas femeninas que se desarrollan, desde el poema, en el siglo XIX. Según Ángel y Kate, sólo se supo que el texto pertenecía a una cubana y que apareció en "El Ancora 'Organo de la Sociedad Popularmexicana del Trabajo/Semanario socialista de política, religión, ciencias, literatura, industria, comercio, variedades México,' T. I, número 13, del 23 de febrero de 1878" (128). Hasta ahora nadie ha explicado la razón por la cual apareció anónimamente este trabajo, publicado 20 años después de la muerte de Adelaida del Mármol. Desde el mismo título se convoca a la reflexión:

\title{
Razones de una poetisa.
}

\author{
Vosotros que murmuráis \\ sin tener quizás razón \\ y a la mujer condenáis \\ tan sólo porque dudáis \\ que tenga imaginación ${ }^{75}$ :
}

Vosotros que sin conciencia

de vuestra opinión sutil ${ }^{76}$,

decís que saber y ciencia

son de hombres de experiencia, 
no del sexo femenil.

Y emitís el parecer

de que la escoba, el puchero,

primorosa en el coser

y no mirar el tintero,

es misión de la mujer.

Escuchad las reflexiones

que en mi tierna fantasía,

formaron las impresiones

de esas mismas expresiones

cuando las oyera un día.

¿Creéis que la flor trasplantada

en su más risueña infancia,

del valle de la ignorancia

a una selva cultivada,

adquiere brillo y fragancia?

Así también la mujer

que recibe ilustración

desde la infancia, ha de ser 
en la edad de la razón

más exacta en su deber.

Y que itanto os maravilla

que una joven poetisa,

que admira a Larra y Zorrilla ${ }^{77}$

borde una fina camisa

o teja un chal o mantilla?

¡Cuántas veces lentamente

con plácida inspiración

formé una octava en mi mente ${ }^{78}$

y mi aguja diligente

remendaba un pantalón!

Una producción de Heredia

recitaba entusiasmada

tomando punto a una media:

Ved, pues, que no impide nada

al alma que el genio asedia.

Y si algún día el destino

me obliga a barrer mi alcoba, 
¿creeréis que haga un desatino?

Vereis manejar con tino

a una poetisa, una escoba.

Y después que concluyera

el deber que me imponía,

¿qué particular tuviera

que inspirada yo escribiera

una dulce poesía?

Sabedlo, pues, la mujer

que recibe ilustración

desde su infancia ha de ser

en la edad de la razón

más exacta en su deber.

Estas son las reflexiones,

hombres, que debéis hacer,

no injustas acusaciones,

ni dar falsas opiniones

en contra de la mujer. (128-130)

Estos versos son fuente de múltiples comentarios. El hecho mismo de haberse publicado anónimamente en México ya 
levanta sospechas puesto que, sin embargo, no se esconde que su creadora fue una mujer. Pero, desde este anonimato "transitorio," dejó un agudo examen de la sociedad decimonónica en la que vivió. Esta exégesis, sin un nombre que lo respaldara, convirtió su voz única en voz de todas las mujeres de su siglo, no sólo de las intelectuales, aunque el reclamo nazca desde una de ellas. Es indiscutible una creación femenina que está dirigida al hombre y a su pensamiento patriarcal. A este hombre "machista" que las ve y las trata como objetos de su deseo, como ángeles del hogar que no sienten eróticamente y que, mucho menos, piensan. Indudablemente, Adelaida del Mármol muestra que fue una persona educada, culta y que tuvo acceso, además de a los libros, a publicar; ella había leído a la Juana de Asbaje y Ramírez de Cantillana la cual, dos siglos antes, escribiera: "Arguye de inconsecuente el gusto y la censura de los hombres que en las mujeres acusan lo que causan" (322).

Sin duda alguna, en la primera estrofa se remonta a la Sor Juana Inés de la Cruz de "Hombres necios que acusáis[...]." De inicio a fin se percibe a una persona con plena conciencia de sí misma, como ser valioso ante la sociedad y como igual del hombre, a quien, en la segunda estrofa, ataca directamente y le dice inconsciente, echándole 
en cara su crencia machista que la sabiduría y lo científico son patrimonios exclusivamente masculinos, así como también la creación literaria; y que las labores de la casa son "atributos" femeninos. En estas primeras tres estrofas, compendiadoras de la visión de la época, -es decir, que todo se ve según el punto de vista patriarcal o del "macho,"- se basa la poetisa para volcar sus "reflexiones" que piden imperativamente sean escuchadas -la cuarta comienza con: "Escuchad..." Son las razones maduras de la poeta que desde su niñez advirtió las desigualdades entre los sexos. En las estrofas 5 hasta la 12 defiende la posición de alguien que "recibe ilustración/desde la infancia," que no se riñe con la dedicación a las tareas domésticas y que lleva a cabo labores intelectuales. La 7 y la 9 citan las lecturas de los románticos penísulares o cubanos de su tiempo: Larra, Zorrilla y José María Heredia. En la última, la 13, vuelve a dirigirse directamente a los hombres diciéndoles lo que deben hacer. Representa este poema un documento de defensa femenina y la esencia de su voz -coral- que lucha por una sociedad mejor y más justa donde se iguale a su compañero. Sin embargo, hay que señalar que aún desde el texto la autora se sitúa como intelectual -aun de avanzada- que no ha salido de las cuatro paredes de su hogar y desde donde, con la doble función de 
"ama de casa" y poetisa, vive. Finalmente, el investigador Luis Antonio Jiménez lo nombra "poema [...] de matiz feminista" (161), y ve en Adelaida del Mármol, gracias a esta obra, una "postura sarcástica de la poeta" (161).

Los textos de Adelaida del Mármol aparecieron, además de en las revistas nombradas, en el El Kaleidoscopio, y en varias antologías: Cuba poética (La Habana, 1855), Album Poético Fotográfico de Escritores y Poetisas Cubanas, de Domitila García de Coronado, y Florilegio de escritoras cubanas, de Antonio González Curquejo; así como en La poesía lírica de escritoras cubanas, de Carbonell.

Sobre el único libro que publicara en vida dice Cabrera Araújo:

Otro de los aspectos de su vida que aún no está del todo aclarado, es la edición y publicación del libro de poesías Ecos de mi arpa, del cual muy poco sabemos. Una bibliografía de autores holguineros [...], señala su publicación en 1854; en el periódico Norte (Holguín) del 21 de agosto de 1958 se afirma que fue publicado en 1855, pero una autoridad en la bibliografía cubana como lo es Carlos M. Trelles, lo sitúa en 1857. [...]. Desafortunadamente no podemos en estos momentos 
negar ni afirmar nada sobre el tema, ya que no hemos encontrado el libro [...]. (N. pág.)

Realmente el año de publicación del poemario cae dentro de una nebulosa. El estudioso Zenobio Hernández Pavón, en carta al autor de este trabajo, afirma "[s]obre «Ecos de mi arpa», se dice que se publicó en Santiago de Cuba pero en mis investigaciones encontré, en El Redactor del 16 de abril de 1856, que éste se publicaría en Matanzas. [Pues en] [e]ste año 1857 no hay casi publicaciones en Santiago." Hernández Pavón aclara que aún está pendiente un examen de las fuentes matanceras.

Al morir Adelaida del Mármol, la noticia de su fallecimiento apareció en los periódicos del país. Así consta en La Alborada, de Villa Clara del 2 de noviembre de 1857, días después de ocurrida, donde figura una nota necrológica reproducida por El Liceo de La Habana el 4 de diciembre de igual año (Cabrera 42). Varios personajes de relieve nacional de las letras cubanas se hicieron eco de esta temprana desaparición. Le cantó Juan Cristobal Nápoles Fajardo, "El Cucalambé," en un texto titulado "A Adelaida de Mármol para su corona fúnebre," que salió en El Redactor, de Santiago de Cuba, el domingo 12 de septiembre de 1858. Antonio Bachiller y Morales (1812-1889) le dedicó un poema titulado "Lágrimas 
sobre el sepulcro de Adelaida del Mármol," (El Kaleidoscopio, 19 de julio de 1859). Por su parte, Luisa Pérez de Zambrana, de quien había llegado a ser íntima amiga, le compuso dos textos elegíacos: "Está muerta," publicado en 1859, del cual aclara Lourdes González Herrero "que, sin saberlo, daría inicio a las páginas de dolor por los ausentes a las que estaba predestinada" (43) dicha poeta; y "Flores sobre su tumba ${ }^{79}, "$ que viera la luz en 1860. 
Capítulo III. Declinación del romanticismo

\section{Martina Pierra de Póo.}

Natural de Puerto Prícipe, hoy Camagüey, nació el 8 de febrero de 1833. Murió el 31 de mayo de 1900 en La Habana. Sus restos están enterrados en la capital de Cuba, como lo pidiera en "La Habana y el Camagüey," uno de sus textos. Según Herrera de Herrera: "á la tierna edad de once años ya componía notables versos" (N. pág.), mientras que Rocasolano afirma que sólo "[t]enía quince años cuando publicó un poema en El Fanal" (109). Añade, este crítico y antólogo, que fue desterrada de su provincia natal, en 1851, por haber enviado a Joaquín de Agüero ${ }^{80}$ un soneto patriótico, aunque sin valor literario, pero de exaltada adhesión separatista, junto a una bandera cubana (109). El Diccionario de la literatura cubana añade que "fue sancionada a permanecer fuera de su provincia por considerársele implicada en el levantamiento encabezado por [...] Joaquín de Agüero" (II: 787), a quien llaman su "pariente inmediato" (II: 787). Quizás ésta sea la causa por la que gozaron de gran popularidad entre los cubanos independentistas sus poemas "A la muerte de Joaquín Agüero" y "Libertad."

Luego de la confiscación de todos los bienes de su familia se trasladó a La Habana en 1859, cuando contaba 26 
años. Allí se casó con José de Póo (1833-1898) poeta menor de la misma edad que ella y escritor además de "comedia[s] de corte literario" (Max Henríquez Ureña I: 247). En la capital, Herrera afirma que brilló como aficionada al arte dramático en la escena de algunas cultas sociedades de recreo (N. pág.), como el Liceo de La Habana, el Liceo de Guanabacoa y en La Caridad de El Cerro. En el primero de estos "[a]ctuó como protagonista en los dramas la trenza de sus cabellos y Borrascas del corazón, de Rodríguez Rubí" (Diccionario II: 787). Fue colaboradora de varias publicaciones, entre ellas el Album cubano de lo bueno y de lo bello, que fundó y dirigió Gertrudis Gómez de Avellaneda, Las hijas de Eva, Recreo de las $\underline{\text { damas, }}$ Revista de Cuba, El Fanal, Brisas de Cuba, El Fígaro, Cuba y América, La Familia, La Ilustración Cubana y El Hogar; pero no dio a la luz libro alguno. Fueron muy elogiados en su tiempo los poemas "A Italia" y "El viajero."

Rocasolano afirma "[l]os poemas que conocemos de Martina Pierra, son declamatorios y de escasísimo valor" (109), mientras que, en su tiempo, Herrera de Herrera, en 1893, expresó que sus poesías habían obtenido "justas alabanzas" (N. pág.). Y se refería específicamente a "El viajero," "A Italia," "Lucrecia," "Venganza de Cupido," y "algunas otras" que no especifica. González Curquejo afirma que "[a]barcó 
todos los géneros poéticos y sus composiciones cautivan o por la dulzura y sentimiento o por la varonil energía con que expresan sus pensamientos; así como por la propiedad del lenguaje" (II: 11), (énfasis nuestro).

Es interesante el tema que subyace en "Lucrecia," soneto que aparece en Herrera de Herrera, en González Curquejo y el único texto que cita Rocasolano. En él, Martina Pierra trata de la violación femenina. En la composición se habla de la dama romana, quien, luego de haber sido violada por Tarquino Sexto, hijo de Tarquino el Soberbio, séptimo y último rey de Roma (534-509 a.c), se suicida. Hecho ocurrido cinco siglos antes de Cristo y que trajo como resultado una revolución, la caída de la monarquía y el restablecimiento de la república romana:

\footnotetext{
De patrio ardor el corazón se inflama, Y luchó en la batalla Colatino. Mientras el hijo del feroz Tarquino, Urde contra su horror, horrible trama.
}
Vuela aquél do su esposa lo reclama, Y oye su acento, noble y argentino, Que le dice: "Morir es mi destino, Manché mi honor, pero salvé tu fama! ${ }^{81}\left(22^{82}\right)$ 
Sea cual fuere el motivo que llevó a Martina Pierra a tomar el ultraje y el posterior suicidio de Lucrecia, se refleja en el texto su conciencia ante tal acción, así como la moral de la época. El último terceto es el resumen de los hechos y la proyección, quizás, de los sentimientos de su autora: "Ya la existencia es para mí desierta;/Y antes que intentes perdonarme viva/Honrada quiero que me llores muerta!" (22) . Es de notar cómo la fama del hombre era tan importante que poco interesaba la vida de la mujer, su compañera, aunque ella no tuviera culpa alguna de lo acaecido. El suicidio no es más que expresión de la muerte social que de todas maneras sufriría debido a las leyes del medio donde vivía.

"El Ateneo," es un largo poema que muestra la erudición frecuente en la lírica de Martina Pierra, pero además otros motivos propios del período romántico. Vemos así patriotismo inmerso en su religiosidad:

El amor de la patria, amor sublime, Dulcísimo y profundo, Que en nuestras almas el Creador imprime;

En mi seno brotó noble y fecundo Desde mi tierna infancia. Por él los golpes del feroz destino Arrostré con impávida arrogancia, 
Que de ese amor bajo el influjo ardiente,

El hombre más cobarde es un valiente

Y el pueblo más humilde otra Numancia. (13)

Y continúa cantando a la patria cuando realza la hermosura de su naturaleza:

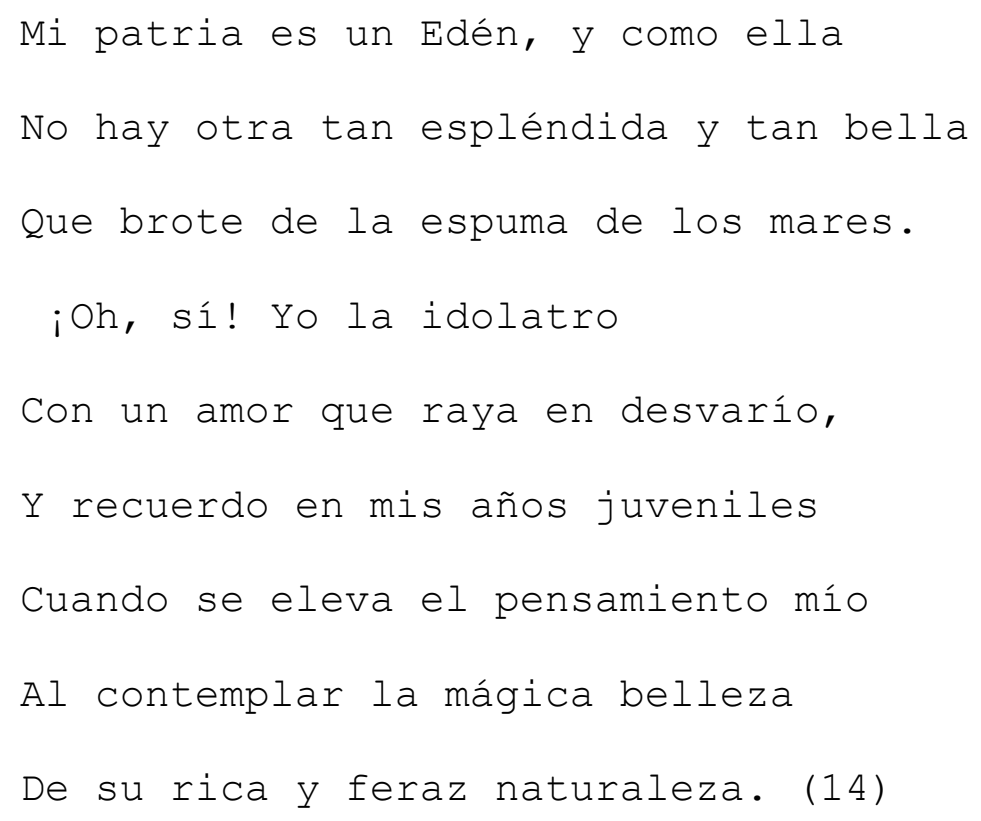

En igual texto proyecta algunas de sus lecturas: "Tula, Milanés, Tolón, Heredia" (15); y expresa un deseo sólo concebible al hombre de su tiempo, la ambición de gloria:

Que mi nombre los nombres eclipsara

De Safo y de Corina; y más que a Homero

De admiración henchido

Me aplaudiese entusiasta el Orbe entero. (15)

Todo lo quiere, según afirma, para dedicárselo a Cuba, a quien compara con las naciones europeas. La poeta desea que Europa 
mire y salude a su patria como la "moderna Atenas" (16). Esta comparación con países del viejo continente también la hace con Italia, en un poema dedicado a dicha nación. Sin embargo, Martina Pierra nunca nombra a España. Cuando menciona a artistas e intelectuales de otros sitios prefiere a los romanos y a los griegos, lo que unido al canto por su isla y a otros versos en que habla de las tiranías, puede verse como una proyección de sus ideas de independencia.

"El viajero," dedicado a su esposo, es un exquisito texto, descriptivo inicialmente, que luego toma un tinte reflexivo por medio de una comparación entre los dos temas que trata. En la primera parte se manifiesta el exotismo común en Martina Pierra: un hombre avanza por un desierto africano, sudoroso, sediento, exhausto; cree que va a morir pero, como un rayo de esperanza, encuentra un oasis que lo hace sumergirse en "religioso éxtasis" (18). Pinta después la naturaleza paradisíaca del sitio: manantiales de agua pura, ruiseñores que cantan; datileras que le ofrecen sus frutos, una alfombra de flores; un "paisaje espléndido y risueño" (19). En un verso posterior expone que el viajero ha "realizad[o] su esperanza" (19). El hombre "entonces comparando alegremente/El mal pasado con el bien presente,/Bendice a Dios por su feliz destino" (20). La 


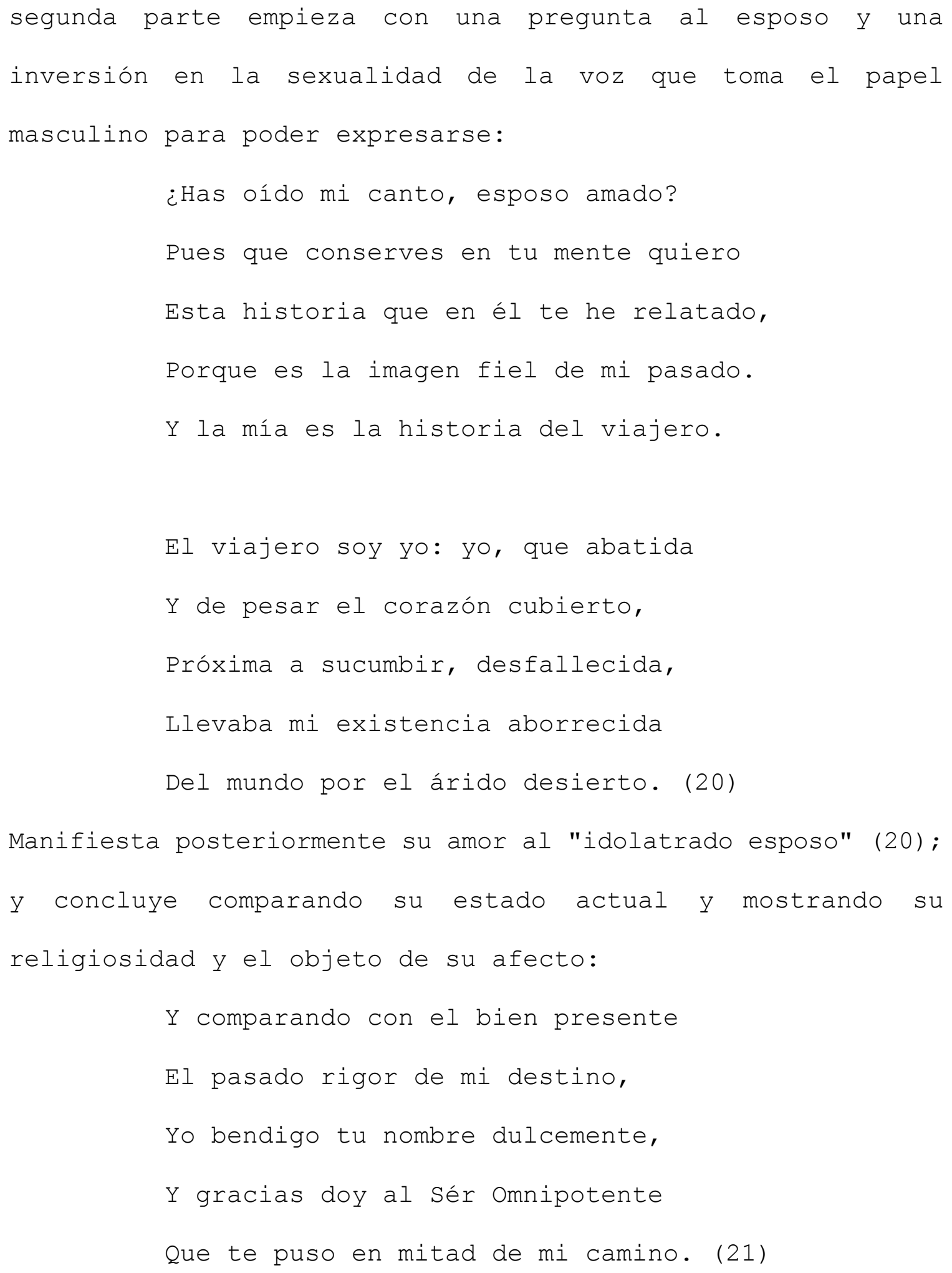


A pesar de que su soneto más celebrado ha sido "Lucrecia," hay otro, "El León y el Esclavo," de motivo romano, tan logrado como el anterior, aunque menos importante para nuestro estudio por no reflejar la situación de la mujer o sus luchas. Lo romano es característico en Martina Pierra, quien se sentía muy atraída hacia Italia, su cultura y su historia. El texto es también un medio de expresar la situación de Cuba. La poeta versifica una historia de Aulo Gelio, el crítico y gramático latino del siglo II ${ }^{83}$.

Por caprichos de un César insolente,

Que humilde acata un pueblo corrompido,

En el Circo, de Roma, envilecido,

La inmensa multitud ruge impaciente.

Salta el león sobre la arena ardiente:

Sacude su melena enfurecida,

Arrójase a su víctima atrevido,

Y al llegar retrocede de repente.

El esclavo infeliz, Androcles era...

Le conoce el león, lame su mano

En prueba fiel de gratitud sincera: 
Acción hermosa, que enseñó al Romano

Que es más noble el instinto de la fiera

Que el alma despreciable de un tirano! (23)

Este gusto por lo italiano se trata extensamente en "A Italia," donde compara a Cuba con el país europeo: "Yo no te he visto, no..., pero tu cielo/sé que es azul, sereno y transparente/Como el cielo de Cuba" (24). Habla, además, de sus pintores y de sus escultores: "Angel, Celline y Rafael divinos" (25); y de la ópera italiana:

¡Y cuánto goza el alma

Al escuchar la música divina

Que nos legara el genio

De Verdi y de Rosini,

Del dulce Donizetti, de Bellini: [...]. (25)

No olvida a los famosos poetas italianos, y vierte criterios metapoéticos, pues manifiestan sus idea sobre la creación:

Y la dulce y sublime poesía, ¿Dónde intérprete halló que más brillante

En el mundo vertiera esa armonía

Que vierten en sus cantos

Tasso, Virgilio, Dante

Y el sublime Petrarca, [...]. (25) 
Posteriormente, deja ver sus ideas de justicia social. Lo hace comparando a los hijos de Cuba con los de Italia: "Y cual los tuyos, con heroicos pechos,/Han combatido sin cesar valientes/iPor conquistar del hombre los derechos" (26). Dedica, antes de concluir, varias estrofas a José Garibaldi (1807-1882), y al célebre ministro de Víctor Manuel II, Camilo Benso, conde de Cavour, (1810-1861), quien preparó la unidad italiana.

¡Garibaldi, Cavour!, grandes prohombres ¡Qué no tenéis iguales en la Historia!

Permitid que en mi canto ¡Evoque aquí vuestros augustos nombres! Que es tanta su grandeza

Y los admiro tanto, Que ante ellos quiero, en mi entusiasmo santo, Inclinar reverente la cabeza. (27)

"Venganza de Cupido," aparece en Herrera de Herrera con el subtítulo "anacreóntica." A imitación del poeta griego Anacreonte, los asuntos tratados son ligeros. En este texto, en segunda persona, la autora se encuentra con Cupido, quien luego llora por haber lanzado sus flechas sin alcanzar a nadie ya que:

Te miras destronado, 
Cesó tu poderío,

Pues no hay un solo pecho

Que no esté guarnecido

Por cota impenetrable

De cruel positivismo;

Y en ella iay Dios! se estrellan ${ }^{84}$

Tus dardos encendidos. (33-34)

La autora se ríe del dios a quien manda junto con sus flechas a Páfos, Chipre o a Gnido, parajes donde aún es adorado, ya que, según ella, en el sitio en que lo encontró se burlan de él mirándolo vencido. Cuando se aleja del lugar, la poeta se siente herida y se da cuenta que ha sido Cupido quien, para vengarse, ha hecho que ella se enamore.

No encontramos en Martina Pierra de Póo muchos de los temas frecuentes en el período romántico, especialmente los motivos fúnebres y la tristeza que embarga los textos, así como los poemas familiares. Se observa sí, en ella, las alusiones a su relación conyugal, su amor por la naturaleza y su patriotismo; así como un exotismo que se traslada a África y a Europa; a Italia y a Grecia, fundamentalmente, sin mencionar a España, posiblemente como una proyección de ideas independentistas. Llama la atención su erudición y el cuidado de sus versos. A pesar de que muestra ideas de justicia social 
y de admiración por los héroes que luchan por la unificación de sus países, no aparece abiertamente dentro de su poética lucha alguna por la liberación de la mujer aunque se le notan rasgos no asociados a la figura femenina decimonónica y que eran entonces patrimonio del hombre: quiere alcanzar la gloria, aún por encima de figuras como Homero, e incluso, en

el poema "El Viajero," retoma un papel masculino para la primera parte de la composición, volviendo a la voz femenina en la segunda parte del trabajo para expresar su profundo afecto matrimonial.

\section{Aurelia Castillo de González.}

Nació en Puerto Prícipe, hoy Camagüey, el 27 de enero de 1842. Murió en la misma ciudad el 6 de agosto de 1920. De "la desafiante Aurelia" ("El Discurso" 28) como la nombra Mirta Yañez, Rocasolano informa que la prosa ocupa la mayor parte de su obra, pero que también se dedicó a la poesía. Sus primeros estudios los hizo con Fernando Betancourt, prestigioso educador camagüeyano (Lezama 3: 405). Comenzó a escribir a muy temprana edad. Se casó en 1874, a los 32 años, con el militar español Francisco González del Hoyo, quien, según Lezama, había tenido que retirarse por haber protestado de los fusilamientos de Antonio Luaces y Miguel Acosta. Al año de su 
matrimonio y estimulada por el esposo, quien apoyaba su desarrollo cultural, viajó a España, donde vivió aproximadamente tres años. Allí dio a conocer en 1879 sus $\underline{\text { Fábulas }}^{85}$ y colaboró en la revista $\underline{\text { Cadiz }}^{86}$, en Crónica Meridional, de Almería, y en El Eco de Asturias.

De regreso a Cuba, se instaló en Guanabacoa y continuó su labor de publicación en la Luz, La familia, El País, El Camagüey, El Pueblo, El Progreso, El Fígaro, Revista de Cuba, Revista Cubana, La Habana Literaria y La Habana Elegante. Colaboró además en Bohemia Social y Cuba Contemporánea. Asistió a las tertulias literarias que se llevaron a cabo en casa de José María de Céspedes, el hermano de Úrsula Céspedes de Escanaverino. Posteriormente emprendió un viaje de estudio por Francia, Suiza, Italia y Alemania. También visitó los Estados Unidos y México. Enviudó en 1894.

Fue deportada de Cuba en dos ocasiones. En una, explica Rocasolano, debido al pésame enviado a Alfredo Zayas por la muerte de su hermano en el campo insurrecto. Lezama, al referirse a la segunda ocasión, expone que en 1895, "el general Weyler ordena su expulsión, por su simpatía nunca disimulada por la causa del separatismo" (3: 405). Este hecho -también tratado por Yañez en "El discurso"-, motivó otra 
estancia en la metrópoli de 1896 a 1898, luego de cuyo retorno, afirma Yañez en su artículo:

ya tenía un bien ganado prestigio y también cierta fama de carácter «viril». Tal vez el mote viniera bien ganado por su permanente actitud rebelde ante los preceptos patriarcales machistas. Su feminismo es claro y rotundo. Reflexionó mucho sobre el tema de la mujer y llenó un vacío al escribir sobre otras poetisas de la época. (28-29)

Aurelia Castillo estuvo entre los fundadores de la Academia Nacional de Artes y Letras en 1910, de la que fue vicedirectora de la Sección de Literatura. Vertió al español La figlia d'Iorio, de Gabriel d'Annunzio; y entre otras traducciones cuenta con "El lago," de Lamartine, que tiene como dedicatoria: "A mi querido amigo Julián del Casal," quien en Bustos y Rimas, le dedicó uno de los bustos ${ }^{87}$. Casal dedica sólo dos de ellos a mujeres -la otra escogida fue Juana Borrero-.

De Aurelia Castillo, en un lenguaje puramente modernista, dice:

Una estátua de jaspe rosado, coronada de nieve. Los ojos verdes, de un verde marino, lanzan miradas severas, atenuadas por cierta dulzura femenina y 
cierta melancolía secreta. Los labios, color de fresa, si se entreabren ligeramente para dar paso á una sonrisa, ciérrense al punto con fría rigidez. Hay en el conjunto de su figura la majestad de una patricia romana y la gracia de una duquesa del siglo dieciocho. Tal es, á vista de pájaro, en lo físico. (N. pág. )

En tres ocasiones, en el capítulo dedicado a Aurelia Castillo, Casal, se refiera a ella como de alma viril: "[s]u espíritu," dice, "como el de toda camagüeyana, esencialmente varonil" (52), (énfasis nuestro), por lo que se sobreentiende que está comparándola con la primera gran poeta de dicha provincia, Gertrudis Gómez de Avellaneda; o más bien con la fama que la persiguió. Posteriormente señala: "Durante la lectura, el lector siente latir, en las páginas del libro, el espíritu varonil de la autora, templado para la acción y rebelde al ensueño, que se enamora de todo lo grande, de todo lo verdadero" (58), (énfasis nuestro), lo que apunta al modo de pensamiento intelectual de la época que continúa la vía utilizada por otro poeta contemporáneo de Julián del Casal, José Martí, cuando éste se refirió a la Avellaneda para compararla con Luisa Pérez, en su crítica del libro poetisas americanas. Al concluir su ensayo, Casal repite el juicio 
sobre la virilidad del alma de Aurelia Castillo: "[y], por último, una página negra, la de la vuelta á la patria, en la que le asedia, al tocar sus playas, las tristezas de sus miserias y la nostalgia de la civilización. Es la página más bella, más varonil, más enérgica y más oportuna" (60), (énfasis nuestro). Max Henríquez Ureña, por cierto, dice que Julián del Casal, en Bustos, delineó la fisonomía intelectual de algunos cubanos prominentes entre los que se cuenta Aurelia Castillo (II: 147).

Aurelia Castillo describió también en 1886 una biografía de la Avellaneda con un juicio crítico sobre sus obras. Según Herrera de Herrera, publicó "un folleto conteniendo su composición Adios de Víctor Hugo á la Francia de 1852, premiada en una tertulia literaria [...], [e hizo] un prólogo a las poesías de Mercedes Matamoros (N. pág.)," y a las de Nieves Xenes. Escribió además sobre Lola Rodríguez de Tió, sobre los Borrero y sobre Emilia Bernal de Labrada. Y apareció en la colección Arpas Cubanas publicada en 1904, donde se incluyeron 29 autores, entre ellos varias mujeres ${ }^{88}$. Ya en su madurez, Aurelia Castillo de González editó sus obras completas, con una breve tirada de 100 ejemplares. 
2 a. Poesía

Entre sus temas se encuentran la patria y sus héroes, el amor filial; "el canto épico y el reflejo de las desventuras de los terribles tiempos que corrían" (Yañez, "El discurso" 30); la naturaleza europea puede observarse en su soneto "Los Alpes," antologado por Valentín Riva Abreu en su Parnaso Cubano (88); así como la búsqueda de la igualdad entre el hombre y la mujer. También trascurren por sus versos hechos históricos, como las relaciones entre Pío IX y Víctor Manuel, rey de Italia; O libros de ciencias como La Atmósfera de Flammarión -para dar explicación sobre el tamaño y la caída de un aerolito-; Newton y la gravedad, Aristóteles y Franklin, entre otros.

Su libro Fábulas, que viera la luz en Cádiz en 1879, cuando Castillo tenía 37 años, se reeditó tres décadas después, tras haber cumplido los 68. Esta diferencia, de la que está consciente, la lleva a comentar: "no en vano se viven algunos años más" (VII). Comienza el tomo con una dedicatoria "A los niños de Cuba," donde muestra "interés por su pefeccionamiento moral é intelectual, como importantísimo factor de felicidad [...]" (N. pág.). Pero también, en él se encuentran versos con preocupaciones políticas escritos para otro público. 
En la composición LXIX "El perro enfermo," hay un supuesto "animal" importante que tropieza en una calle y permanece encerrado esperando su curación. Hasta allí acuden sus compañeros y cada uno le ofrece sus remedios. El doliente les contesta que no tiene nada de cuidado, pero los otros logran sugestionarlo y, con ello, que siga sus consejos. Estos terminan dejando moribunda a la hipotética bestia, que no tenía nada considerable. Así concluye:

$$
\begin{aligned}
& \text { [... Mas no ven los doctores } \\
& \text { que todos de su muerte son autores. }
\end{aligned}
$$

Políticos profundos é ilustrados, ¿no os miráis en mis perros retratados?

Procedéis de tal suerte, que amando á la nación le dais la muerte ${ }^{89}$. (102) Quizás este modo directo de hablar de Castillo fuera el que impresionó a Casal para decir que era varonil al describirla. Con ello quiso decir que era capaz de arrostrar los males sociales y no permanecer meramente en la poesía dedicada a los jardines, a la amistad, las flores y a la familia como hacian muchas otras que no se enfrentaron al statu quo de su tiempo. 
Al final de Fábulas, agrega lo que llama "Máximas," así como varias de estas composiciones traducidas al inglés ${ }^{90}$. En la segunda edición (1910) hay una nota aclaratoria donde consta que continuó los trabajos en su propia obra, eliminando textos y añadiendo otros. En esta versión, Castillo refiere que el libro fue criticado en la prensa por autores que juzga como "demasiado benévolos" ( (VI), y expone una oración que nos da una idea de la situación de la mujer intelectual de su época en cuba y, muy importante, su visión crítica: "Las escritoras de nuestro país vivimos en lamentable aislamiento literario. No tenemos á quien consultar, no cambiamos impresiones con nadie. Tememos molestar a los hombres literatos y científicos, parecerles, en fin, impertinentes" $(\mathrm{VI}-\mathrm{VII})$

Reafirman esto último algunos de los versos de "Expulsada," cuando hablando con al esposo -su hombre más cercano-, la autora enmascara sus ansias de equidad y las llama "alardes." Un modo sutil de afirmarlo, de todas formas, ante la crítica patriarcal que intentaba sujetarla. En esta composición, escrita al año de desaparecido su compañero hay dos estrofas -6 y 7- que muestran un deseo de igualársele. En la primera vemos:

$$
\text { Y de pronto te dije con juvenil locura, }
$$


estrechando en mi mano tu mano grande y fuerte, como de hombre a hombre, cual de Oreste a Pilades, «iCompañeros y amigos hasta la misma muerte!»

(Rocasolano 112)

En los dos primeros versos de la estrofa siguiente, la séptima, aparenta criticarse a sí misma: "Irradió tu semblante con íntimo contento,/de igualdad y de fuerza oyendo mis alardes [...]" (112), lo que no es más que un modo de enmascarar sus verdaderos sentimientos ante su época.

Desde el primer texto de las Eábulas, aclara que no todas deben llamarse de ese modo y que procura que dejen una enseñanza. Véase "El sol y la luna," la primera de estas composiciones que encierra una alegoría:

Tras la estela del sol esplendorosa marcha sin fin la luna presurosa. Jamás alcanzará lo que persigue, pero sus rayos reflejar consigue. Un ideal propónte con firmeza, sin que nunca te asuste su grandeza.

Si no llegas á serlo semejante, su reflejo serás, y eso es bastante ${ }^{91}$.

Esta ficción alegórica se aclara por sí sola. El sol es una representación de lo masculino y la luna de lo femenino. 
Apliquémosle la explicación simbólica a este trabajo, realizada por Ivan A. Schulman en la obra martiana (las Fábulas de Aurelia Castillo, se escribieron en 1879, tres años antes que Ismaelillo, de Martí). Según Schulman, en la antigüedad griega y en las civilizaciones precolombinas de América "el sol era considerado símbolo de poder creador."-Y continúa-: "[e]l cristianismo mantuvo este significado al identificar la fuerza divina con el sol" (140). Y en la cultura de Aurelia Castillo, eminentemente católica, ese poder creador viene de un Dios que se presenta como entidad masculina. En cuanto a la luna, Schulman señala que "simboliza pureza y perfección moral" (183); reflejo de un ser femenino éticamente perfecto que en el contexto religioso de la isla no es sino la madre de Jesús. O como dice Yañez, en "El discurso," el "mito romántico de la mujer canonizada como bella, inútil, pura, pasiva, algo tonta y frágil" (19). En los versos tercero y cuarto, hay una afirmación, incuestionable para la poeta, pues impone un aparente "[j]amás alcanzará lo que persigue," aunque "sus rayos reflejar consigue." Y propone un no temer a la grandeza y perseguirla. Claro que la autora aparentemente se conforma con ser un mero reflejo. ¿No estaría Castillo, una vez más, enmascarando su verdadero pensamiento por "[t]em[or a] molestar a los hombres literatos y 
científicos, parecerles, en fin, impertinente [...]"? $(V I-V I I)$.

Una de sus fábulas, la XXVIII, "Las piedras y el corcho," muestra las ideas de Aurelia Castillo sobre el paso de los creadores por la literatura y presenta también la controversia hombre/historia/tiempo humano:

A las aguas profundas de la historia

lanza el tiempo del hombre la memoria;

lanza diez, lanza veinte, lanza ciento....

á contarlos no alcanza el pensamiento.

Muchos, los más, cayendo con gran ruido

van á encontrar el limo del olvido;

y uno entre mil acaso sobrenada,

quizás el que hizo su marcha más callada92.

Quizás fue este carácter de mujer consciente lo que provocó un hecho que narra Yañez:

cierto texto suyo llamado "Eva" (1985), dedicado a Dulce María Borrero, levantó suspicacias que obligaron a su autora a responder, de manera paciente y valiente, y explicar al menos parte de las intenciones del poema en el cual se contrapone alegóricamente la fe religiosa (Morgana) a favor de la Ciencia; y como si esto no fuera ya bastante 
osadía y libre opinión, una lectura actual desde cierta tendenciosa mirada, la conversación entre Eva y Morgana tiene alusiones posiblemente eróticas. De todas maneras, por si las moscas, Aurelia del Castillo aclara a los hombres de su época preocupados por saber dónde iba parar con todo aquello: "en Eva he intentado personificar a la mujer en absoluto, que se emancipa por fin de la tutela en que por tan largo tiempo la ha tenido la iglesia." ¿Argucias para exponer su filosofía positivista a través de la poesía alegórica? ¿Máscara de la marginalidad para exponer ternuras del amor homosexual? ("El discurso" 30-31)

Con la consciencia de un mundo regido por una visión masculina, Aurelia Castillo se decidió por crear. Lo dejó plasmado metafóricamente en su fábula LXXI, "La rosa y las espinas," donde una niña se hiere por arrancar la flor pero de todas maneras lo hace valientemente. Por eso señala:

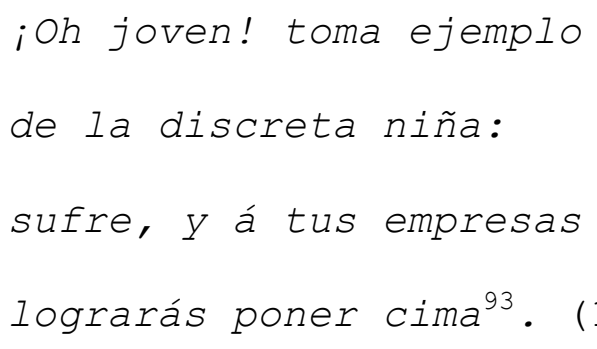


Esta consciencia de las consecuencias que el creador asume, aparecen en la fábula LVIII "El autor y su obra," cuyos primeros versos cuentan:

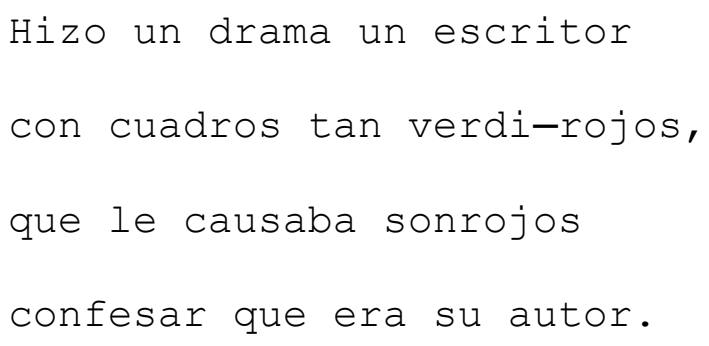
encumbre," ya que no quiere perecer y por eso se propone dejar su obra. Así esculpe la piedra que después destruyen el 
tiempo, los cataclismos o "[e]l hombre mismo [...] en su furor de guerra" (137). Entonces es cuando surge la poesía, cuando el humano se hace poeta, "y el mundo tuvo voz" -afirma Aurelia Castillo- porque:

No ya en el tiempo quedarán perdidos

Excelsos nombres, levantados hechos;

Que es la voz del poeta

Lira, cincel, paleta,

Y en colores, y en formas, y en sonidos,

Y con rasgos de fuego inextinguibles,

Cuanto se eleve y brille y arrebate,

Dejará de los hombres en la mente

Y vivo pasará de gente en gente. (138)

Ésta es la obra que en su tiempo nos legó la que no quiso parecer "impertinente" a los hombres de su época, a los científicos y literatos, por temor de "no molestarlos;" la creadora a quien Max Henríquez Ureña (al hablar de aquellos que figuran en el primer y único tomo del Parnaso Cubano de Antonio López Prieto), pone junto a Fornaris, Luaces, Mendive, Mercedes Matamoros, Nápoles Fajardo, Luisa Pérez de Zambrana, Julia Montes de Oca y Zenea; a todos los que llama "verdaderos poetas" (I: 182); la poeta que Raimundo Lazo afirmó que era poseedora de una "cultura literaria amplia [que] se extendía a 
literaturas extranjeras, francesa, inglesa, italiana, varios de cuyos autores tradujo -Ada Negri, Carducci, Lamartine, Copée, Byron-" (86).

A través de los trabajos de Aurelia Castillo, se descubre a una erudita que igualmente anda los caminos de la humanística como los de las ciencias, raros temas para la mujer de su tiempo. No obstante la exquisitez y el magnífico manejo, presentes en sus fábulas, así como la nombradía que tuvo en su época, para Rocasolano en ella "la idea se sobrepone a la emoción y el concepto señorea sobre la asociación intuitiva. Poseyó el dominio formal, pero le faltó esa oculta vibración que da peso a la palabra en poesía" (111) .

Las fábulas de Aurelia Castillo, todavía se leían en los libros de enseñanza primaria del país cuando Lezama, en 1965, escribió sus volúmenes de Antología de la poesía cubana.

2 b. Cuento.

En el volumen III, de los Escritos de Aurelia Castillo de González, aparecen algunos relatos dedicados "A Camagüey" y que según su autora imprimió en forma de "librito [...] con el exclusivo objeto de hallar[s]e presente en [s]u Feria Exposición" (III: 371). A diferencia de Gertrudis Gómez de Avellaneda, en todo momento Castillo de González los llama 
cuentos, a tal punto que firmado por "la musa popular" (N. pág.), coloca unos versos en la página que precede a estas narraciones: "Os voy a contar un cuento/que una vieja me contó." (N. pág.), (énfasis nuestro). No tienen una maestría expositoria, ni hay en ellos una directa alusión a las luchas feministas, como sí se encuentran en la Avellaneda. Surgen, no obstante, algunas formas indirectas donde Castillo pone a la mujer como ejemplo de su medio y la muestra como una catalizadora social.

Los relatos son once. En algunos de sus títulos, en los que no resulta ser muy afortunada, utiliza la palabra cuento. En varios se da al final una explicación de cómo obtuvo el material que dio base a la historia. Nos referiremos a aquellos que presentan importancia, según el orden que les dio su autora en el volumen III: "Un cuento de Francisca," "Cuento de hadas," "Zapatos de charol," "Origen del Sol," "Cuento en la forma; verdad en el hecho," "Gemelas," "Tipos callejeros," "Bohemia," "El hombre de bronce y el hombre de mármol o La doncella encantada," "Lalá" y "Dulce despertar."

La importancia de "Un cuento de Francisca," fechado en 1887, un año después de desaparecer la esclavitud en Cuba, es que sitúa a una esclava, como "notabilísima narradora de cuentos" (III: 373-374) a tal punto que "apostaba con una 
señorita que tenía el libro de Las mil y una noches a cuál de las dos contaba más, y que ella [Francisca], sin libro [...] había vencido a la señorita" (III: 374). Durante el relato la autora toma a una mujer negra y la presenta como una intelectual. Más adelante, aprovecha su historia para introducir ideas levemente antimonárquicas: "Amada, a quien él respetaba más que a una reina, porque decía aquel buen capitán que más mérito tenía la virtud de una muchacha que andaba por la vida expuesta a mil riesgos, que la de una princesa encastillada en su palacio, a quien nadie se atreve a levantar los ojos para mirarla a la cara [...]" (III: 377). Al final de este relato afirma la autora que Francisca existía aún en junio de 1891 .

"Cuento de hadas," escrito en mayo de 1893, se basa en un hecho aparentemente ocurrido en Chicago, Estados Unidos, y lo convierte en una de sus ficciones. En él manifiesta su admiración por el país norteamericano. Desde el comienzo muestra su visión "Erase una gran nación de gigantes, muy rica, muy rica y muy civilizada" (384). En "cierto barrio de la flamante y hermosísima ciudad" habitada por "hombres de pelo en pecho" (III: 384) y por "rudos atletas" (III: 385), penetró el diablo y comenzó a venderles cerveza. Un tiempo después, el pueblo estaba perdido "[s]e bebía, se bebía. 
Bebían los hombres y las mujeres, los viejos y los niños y cuanto más se bebía, más sed daba" (III: 386). Entonces aparecen tres mujeres, las hadas del cuento, y edifican un palacio donde acuden, poco a poco, los pobladores a nutrirse física y espiritualmente, y así imponen la felicidad y el buen vivir. Enseñan idiomas, agricultura, mecánica, astronomía y música. Finalmente, son las mujeres quienes, venciendo al diablo hacen volver a los atletas de pelo en pecho y a sus familiares al buen camino. Ésta es la manera cómo Castillo expone sus ideas sobre el género femenino. A pesar de hacerlo a fines de siglo, no es tan directa como muchos años antes lo fuera la Avellaneda.

"Origen del Sol," llama la atención porque en él, Dios quita "el sol que alumbraba al mundo/ [pues] era un sol ya moribundo" (III: 400) y, en su lugar, coloca "una piadosa paloma" (III: 400) que, supuestamente, es el astro que hoy nos ilumina y calienta. Es interesante como el sol, símbolo de lo masculino, es eliminado para poner en su lugar un símbolo femenino. Aunque esto se convierte en controversial cuando se piensa que el Espíritu Santo, que es masculino, se representa también por medio de una paloma. No obstante, tal como aparece en Aurelia Castillo, lo tomamos como un símbolo femenino ya que se lee en el texto "una piadosa paloma" y no un palomo, es 
decir el macho de tal ave. Por otro lado, se trata de un relato versificado, único dentro de su producción cuentística, lo cual constituye una suerte de modo de redimir el género en cuestión al narrarlo en verso. De todos las historias tratadas en esta investigación resulta muy original, de parte de Aurelia Castillo, la presentación de su relato en forma de poesía.

"Tipos callejeros," narra la historia de una mujer que pare y abandona a su criatura en una vecindad donde otras, desconociendo los orígenes, cuidan de su crecimiento. El bebé [Daniel], ya adolescente, suele juntarse con otros y burlarse de "cuatro desventuradas que servían de diversión a muchachos y zagaletones" (III: 420). Una de ellas resulta ser la propia madre de Daniel. Al final se descubre la trama y en un párrafo se exponen los hechos: "había recobrado el hijo que su irreflexión y el capricho de un villano hicieron nacer, y que, cometiendo una falta mucho mayor, por vergüenza ante sus padres honrados y severísimos, por vergüenza ante la sociedad, que ellos le habían enseñado a respetar, abandonó a todos sus azares" (III: 423), (énfasis nuestro). Aurelia Castillo, una vez más de forma indirecta, critica aquí la sociedad de su tiempo, apegada a una falsa moral que era capaz de permitir el 
enloquecimiento de una mujer por el hecho de haber tenido un hijo fuera del matrimonio.

La importancia de "Bohemia," radica en que fue escrito para el primer número de la revista de igual nombre, que vio la luz en La Habana, a principios del siglo XX, y que tenía entre sus colaboradores a hombres de la talla de Alfonso Hernández Catá y Luis Felipe Rodríguez. Este hecho muestra que Aurelia Castillo era una autora con quien se contaba en las altas esferas de la intelectualidad cubana de su época.

En "El hombre de bronce y el hombre de mármol o La doncella encantada," el punto de vista tomado por la autora es el masculino: espécificamente el de un abuelo a quien un nieto pide "un cuento" (III: 430). En el relato, fechado en 1911, aparece el enfrentamiento entre seres de etnias diferentes; se presenta la naturaleza patria y se citan algunos versos de José Martí, que había muerto dieciséis años antes. Aurelia Castillo, mediante su voz narrativa, llama a Martí "grande poeta, su Poeta" (III: 432). En el texto hay una manifestación en contra de la esclavitud y nuevamente se introduce a un personaje femenino "una hada muy buena disfrazada de viejecita" (III: 434), quien promete enseñar a leer y a escribir al esclavo, y le asegura, también, que le traerá libros. Esta hada habla además con el hombre de mármol que no 
le hace mucho caso. Posteriormente se unen ambos hombres para salvar a "una mujer joven y hermosa" (III: 436-437) una "doncella cautiva," por un "gigantesco jinete" (III: 436) que resulta ser una alegoría de Cuba y para cuya libertad se unen los dos varones, representantes de los grupos étnicos fundamentales del país.

"Lalá," está precedido por una carta dirigida a "Miguel Ángel Quevedo y Antonio R. Morey" (III: 441), entonces los directores de la revista Bohemia, donde Castillo agradece el cuento que le han pedido para los niños. Es la única narración infantil de esta autora.

La importancia de "Dulce despertar," fechado en "Diciembre 29, 1912" (sic) (III: 446), radica en que apenas con 139 palabras, este relato se adelante en prácticamente sesenta años a los maestros de la cuentística latinoamericana, entre ellos a Salvador Garmendia, Augusto Monterroso, Jorge Luis Borges, Virgilio Piñera, Juan José Arreola y Carlos Monsiváis, quienes han recurrido a esta forma brevísima.

Consuelo Triviño Anzola en su "Microantología del minicuento americano" señala "[e]l relato brevísimo, a caballo entre la poesía y la prosa, ha tenido mucha acogida en nuestro continente. Su fundador, Julio Torri, inaugura el género en 1917 con la publicación de Ensayos y poemas" (24). Este dato, 
que aparece en la introducción de la mencionada antología, revela un desconocimiento de los cuentos de Aurelia Castillo, pues es ella quien inaugura el género en América Latina, cinco años antes que Julio Torri, como hemos visto pues aparece fechado anteriormente al pie de este relato, en el volumen III de sus obras completas.

\section{Rosa Krüger $\mathbf{y}$ del Busto ${ }^{95}$.}

Nació en La Habana en 1847 y murió en su ciudad natal el 4 de abril de 1881. Según Rocasolano, se relacionó con la mayor parte de los escritores de su momento y tuvo una vida literaria activa (115). Su obra poética se publicó en El siglo, El Occidente, La Guirnalda y la Revista de Cuba. Todos sus escritos, que incluyen poesía, cuento, ensayo y traducciones, vieron la luz póstumamente, por iniciativa de José Antonio Cortina, quien los prologó en un volumen titulado Obras de Rosa Kruger ${ }^{96}$. Pero de este proyecto sólo se logró editar un primer tomo.

3 a. Poesía

Al decir de Rocasolano: "su poesía fue encomiada en su momento por reconocidos literatos y por otros algo posteriores" (115), lo que se proyecta en el primer párrafo 
del prólogo de Cortina: "La impaciencia con que los amantes de las letras esperan las obras en verso de la señorita Rosa Kruger, responde á un sentimiento que hace, hasta cierto punto, innecesario este prólogo" (N. pág.). González Curquejo, en 1910, no aporta mucho a lo anterior, afirma que "todas sus obras son de mérito" (127), y aclara que fue precisamente el Dr. José Antonio Cortina, quien la dio a conocer en su Revista de Cuba, por los años de 1877-1881 (127). Este antólogo cree que "[s]ino a la altura de la Avellaneda, ni de Luisa Pérez de Zambrana, Rosa Kruger figurará dignamente en el Parnaso Cubano," considerando que "el género donde más brillaba era el descriptivo" (127). Domitila García de Coronado, que también la antologa, hacia finales del siglo XIX, dice de ella:

Las poesías del género descriptivo eran en gran parte su tema favorito, la verdad del sentimiento, color de las imágenes y entonación suave, abrillantan el paisaje de un modo sencillo, encantador, parecido al tenue reflejo de los rayos de la luna en un lago silencioso; al rumor del céfiro de la tarde en las frondas de un bosque de fragantes mirtos en flor [...] (127) 
Sin embargo, Rocasolano afirma "pero en verdad sus versos nos parecen hoy sumamente discretos, carentes de imaginación y faltos de emotividad" (115).

Varios son los motivos de su poética. Se encuentra en ella la preocupación por el paso del tiempo, que se verá luego en obras de poetas finiseculares como Rubén Darío. Ejemplo de esta temática es "El útimo canto," que habla de los momentos terminales en la vida de un poeta:

Es la hora suprema en que el humano

Resuelve con atónita mirada,

Si es su espíritu un ángel soberano

o un soplo fugitivo de la nada. (17)

$[\ldots \ldots \ldots \ldots \ldots \ldots \ldots \ldots \ldots \ldots \ldots \ldots$

El espiritu vaga, y no se atreve

A pedir á la vida su secreto,

Y obedece el mandato del que mueve

Tanto planeta á su poder sujeto. (18)

Es una composición en la que también aflora su religiosidad, cuyos títulos, por sí solos, explican esta preocupación: "A la vírgen," "A María," "Moisés en el desierto," "La anunciación," "La noche de Navidad," "El ángel de la guarda," "Dejad venir á mí los niños," "Las bodas de Caná," "Dios" y "David," donde resalta constantemente, además, el tema hebreo. 
Por sus textos también discurre la familia. Dedica "la Primavera" a su hermana V., sin completar el nombre, lo que sí hace en "El cantar de la niñez," en el cual escribe «A mi hermana Lila,» mucho menor que ella. Tampoco falta el canto a la naturaleza americana, donde se observa su hedonismo frente a los ambientes bucólicos. Es curioso el número de veces que aparecen los meses de abril y de mayo en sus poemas, así como las alusiones directas a la primavera. Hay además versos a los marginados: al carretero; al esclavo al que compara, en su tumba, con un creador; así como el tema de lo lúgubre, -expuesto en "El sauce"- tan caro al romanticismo.

El amor por su tierra natal, se muestra en las composiciones a los componentes de su naturaleza, como un soneto que no aparece en las obras publicadas por Cortina y que recoge Feijóo. Se titula "La bijirita," 77 "-ave cubana, muy pequeña, parecida a un canario pero de alas verdes y gola amarilla-, que también constituye un canto a la libertad y donde Kruger, comparándosele, se considera esclava, aunque sin referir el por qué o por quién. El tema de la libertad aquí es ambiguo, pues en la época que se escribe esta composición, Cuba estaba enfrascada en sus guerras de independencia y, al mismo tiempo, la mujer permanecía en un estado de esclavitud hogareña, no especificado. Para complicar la exégesis de los 
siguientes versos basta decir que además se denominaba con esta voz -bijirita- a los cubanos de padre español:

Hay en mi Cuba un pobre pajarillo

Que vive libremente en la espesura; [...].

Volando de la jagua al mamoncillo

Sólo su amada libertad procura;

Que él no puede vivir en jaula oscura

Ni llevar en el pie dorado grillo.

Cuando un infame aprisionarlo quiere,

Tras el alambre el infeliz agita

Y en pocas horas de tristeza muere.

¡Oh, sí! Yo quiero ser la bijirita:

Que á mi también la esclavitud me hiere,

Mi paz enturbia, y mi ilusión marchita.

(Feijóo, Cantos 225)

La nostalgia por Cuba resalta en otra composición que posee el lugar donde se realizó, medio por el que sabemos que viajó fuera de su patria. Tenía sus autora 19 años. En Nueva York escribió "La nevada," en la cual una lluvia helada 
desciende y cubre el paisaje. Cuando culmina, Kruger echa de menos su latitud:

Pero ya disminuye

Su fuerza la nevada,

Y la luz deseada

Asoma en el confín;

Mas iay! no la del trópico, [...].

Y más adelante:

¡Oh, dulce Cuba mía,

Lirio del mar Atlante;

De tu zona brillante

Un rayo envía aquí!

Aromas, luz, colores,

Tendrán estos paisajes,

El cielo albos celajes

Y límpido zafir.

En lánguida nostalgia

El corazón sumido,

Más que el ave á su nido

Ama el suelo natal. [...] (35) 
El poema "A Cuba," está fechado en "New Yok, Enero de 1866" (66). A través de él fluye la añoranza por su isla:

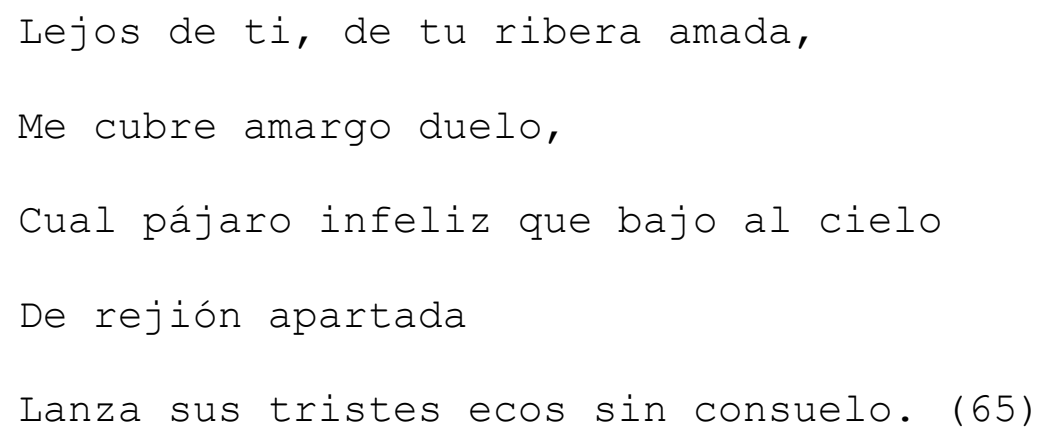


A pesar de que realmente sus composiciones son descriptivas hay textos como "La esperanza," donde están presentes la filosofía y los temas altamente metafóricos:

$$
\begin{aligned}
& \text { iSalve deidad, á quien ardiente el alma } \\
& \text { Rinde entusiasta férvido homenaje! } \\
& \text { Tú, que con dulce y vencedora calma, } \\
& \text { Tienes al mundo en blando vasallaje! }
\end{aligned}
$$

Tú, que recorres con ligero paso,

El áspero sendero de la vida,

Y vagas inconstante y al acaso

Sin que recibas desgarrante herida. [...]

Sin embargo, las pocas citas que hemos encontrado sobre Rosa Kruger, hacia finales del siglo XX, están relacionadas con sus poemas a la naturaleza de su isla. En 1964, Samuel Feijóo la incluyó en sus Cantos a la naturaleza cubana del siglo XIX. Diez años después, Carlos Ripoll también la escogió entre los autores de su libro Naturaleza y alma de Cuba/Dos siglos de poesía cubana/1760-1960.

Otro tema que aparece en sus poemas es el de la mujer, aunque Rosa Kruger sólo menciona directamente el vocablo en dos de sus poemas. Encuéntrase "En la muerte," (la de Julia Pérez Montes de Oca), donde afirma: "Tuvo tu genio inspiración 
completa/En tu alma de mujer" (53). También en otro donde se sobreentiende el concepto que tenía sobre su sexo. En "La amada del poeta," las características de ésta son varias que comparten el criterio patriarcal de época: "nevada rosa entre follaje," "lirio encantador," "belleza pura en los albores," "voz del querubín," lo "más hermoso," "aura perfumada que os envuelve al pasar." Se describe a la mujer como tierna, angelical, bella, pura, cándida, abnegada, símbolo del amor filial, inocente, alma suave, amorosa y fiel (166-174); es decir, no hay diferencia entre ella y la Virgen María que merodea en sus versos juntos a los ángeles. Nunca, sin embargo, se observa una queja en relación al estado de la mujer en la sociedad decimonónica donde vivió.

3 b. Prosa: ensayo y traducciones

En el resto de las autoras sólo nos ocupamos de la poesía y del cuento; en este caso, por hallarse en igual tomo y ser mínima, hemos agregado sus ensayos y sus traducciones. Esta "Prosa" de Rosa Kruger, aparece ocupando un espacio menor en el volumen prologado por Cortina, -desde la página 237 hasta la 326-, con la que finaliza. Además de los trabajos propios, contiene traducciones como "El valor del tiempo y de la instrucción," aunque no especifica quién es el autor, así como los artículos "Moliere" y "Cervantes" de William Hickling 
Prescott, traducidos por ella, donde se habla de la vida y obra de estos clásicos y se abunda en la sociedad en que vivieron y cómo pensaron y escribieron. Si bien no se menciona el idioma del cual fueron vertidos al castellano, supuestamente el original estaba en inglés. Y debe pensarse porque Rosa Kruger vivió, como se ha visto, en los Estados Unidos sólo siete años después de la muerte del norteamericano Prescott (Salem, Massachusetts, 1796; Boston, 1859); pero también porque en un pasaje de "Cervantes," ya traducido por Kruger, Prescott dice "[s]obre estos motivos se recuerda una interesante anécdota, que, por no haber visto escrita en inglés, expondré a los lectores" (302). Prescott fue un historiador estadoudinense, reconocido por sus estudios hispánicos ${ }^{98}$. Aunque no tenemos la obra en inglés, la versión española muestra un conocimiento de ambas lenguas. Júzguese el uso del idioma en "Moliere," por ejemplo, que empieza del siguiente modo:

Los franceses superan á la mayor parte, ó más bien, á todas las naciones de Europa, en el número y excelencias de sus memorias. ¿De dónde procede esta manifiesta superioridad? La importante colección relativa á la historia de Francia, y que data del siglo XII, forma para el investigador inteligente 
la base histórica civil más auténtica, circunstanciada y satisfactoria que encontrarse puede. (250)

El tercer texto vertido al español es "El valor del tiempo y de la instrucción," de idioma y autor no especificados. En él se muestra el mérito de la lectura porque "[1]a sabiduría es poder" (244), y es "[e]l camino del honor, de la riqueza, del bien y de la felicidad [que] se abre á todos [...]. Esta traducción nos enseña a una persona inteligente que sabía que el único modo de salir de su espacio restringido era la cultura. Y, por supuesto, el modo usado por ella para romper las barreras que en su tiempo se imponían a la mujer.

3 c. Cuento

El resto de su prosa está compuesto por cuatro cuentos que son trabajos creativos propios de Rosa Kruger: "El sueño de Berta," "El canario de Dolores," "La abuela" y "El vendedor de periódicos."

En "El sueño de Berta," llama la atención el primer párrafo por sus tintes netamente modernistas. Téngase en cuenta que Kruger murió en 1881, un año antes de que José Martí escribiera su Ismaelillo. Así empieza el relato: 
Suaves, blandos perfumes, brotaban de los rasgados cálices, los lirios de los campos, y una luz

nacarada y cristalina, como el reflejo de una bujía bajo un globo de porcelana rosada, se repartia por los ondulantes valles y floridas colinas de un bello y hechicero país. (237)

Más adelante, describe el paisaje de un modo que continúa adentrándose en una estética nueva: "Riegan sus valles y campiñas claros y bulliciosos rios, que lucen el fulgor de rosa de su cielo, con franjas de pedrería sobre un manto de terciopelo" (237). Este cuento trata de una joven, Berta, que se ha quedado dormida y llega a las playas de un lugar paradisíaco. Allí la recibe un ángel que en determinado momento le dice "Si eres poetisa, canta; pinta si eres artista" (240). Ella se decide a tomar el pincel y el ángel le despliega un lienzo. Berta pinta y sus ríos y colinas "tuvieron vida" (240). Inconscientemente, el personaje femenino de Kruger, -la poeta cuyos versos muestran su religiosidad-, pasa a ser el dios creador. Cobra mayor importancia cuando el hecho ocurre oníricamente. Es decir que Berta, creación de Kruger, sueña ser un personaje masculino, y no cualquier personaje, sino el más importante de ellos: Dios. 
Luego Berta despierta y lo único que nota es que, durante el sueño, se ha avejentado.

"El canario de Dolores," con una prosa que sigue los parámetros de la anterior narración, es el relato de una joven que tiene un ave enjaulada, regalo del padre, que guarda desde la infancia. Dolores y el canario cantan a dúo en una atmófera edénica. Kruger habla del encarcelamiento del canario, que no es libre a pesar de vivir entre flores y rejas doradas. Consciente de las necesidades del animal, en cierta ocasión, posterior a la muerte de su progenitor, Dolores entabla una conversación con el ave donde proyecta sus ideas: "Te pregunto si sufres, á ti, que estás aprisionado, con cadenas de flores, es verdad; pero que no pueden compensarte el goce de tu perdida libertad" (247). Durante las reflexiones de su ama, la "preciosa avecilla," se mantiene "muda é inmóvil." Posteriormente abunda en el tema:

$$
\begin{aligned}
& \text { Las aguas sosegadas que corren por el valle en } \\
& \text { curvas infinitas, las plantas y las flores que se } \\
& \text { doblan airosas en sus orillas, como queriendo } \\
& \text { contemplarse en el líquido espejo, los árboles que } \\
& \text { ostentan majestuosos sus ramas cargadas de frutos, } \\
& \text { la selva espesa donde revolotean juguetones tus } \\
& \text { hermanos; todo esto es tuyo, y, sin embargo, nada }
\end{aligned}
$$


tienes, de nada puedes disfrutar pobre cautivo!

Termina esta conversación con una pregunta que se formula a sí misma la protagonista: "¡Oh ceguedad! ¿Es acaso feliz el que no es libre?" (248). Al final, Dolores pone en libertad al pájaro regalo de infancia del padre. No se sabe cuándo escribió Kruger este relato. Parece obvio que aquí el pájaro es una proyección de la creadora -como el jilguero enjaulado en los poemas de la Avellaneda y de Adelaida del Mármol- y es, por ende, la de la mujer escritora de su tiempo, quien, al desaparecer el poder patriarcal queda libre como el ave canora del cuento.

Al concluir el relato, ya liberado el pájaro, señala la narradora: "Un raudal de notas argentinas brotó de su garganta, y, ligero como el viento, fué á posarse sobre las ramas de un pomposo granado, y batiendo con orgullo sus alas de oro, desapareció luego por entre los árboles frondosos" (249). Si retornamos al trabajo de Ivan A. Schulman sobre los símbolos martianos, encontramos un apoyo a nuestra interpretación de la alegoría de estas aves -recordar "La bijirita"- que "son imágenes recurrentes que evocan un sentido de dinamismo frustrado y un ansia de espacio que son los equivalentes físicos de un idealismo moral y filosófico" 
(114). Parece ser evidente que las intelectuales como Rosa Kruger se veían frustadas ante el machismo imperante y debían sentir, como una constante, esa necesidad de espacio que expresa la interpretación de dicho crítico martiano. Esto, unido a la explicación de las "alas de oro" que da el mismo autor: "oro [...] sugiere refinamiento, calidad artística, excelencia literaria, todo lo que es noble y sublime, emparejado con alas, se usa como portador de un juicio estético" (134)-, creemos que respalda con creces la comparación de ave enjaulada con mujer decimonónica; con la esclavitud de ésta por el hombre y, en definitiva, por la sociedad y sus normas.

El tercer relato es "La abuela." En él se habla de una anciana, la cual, rodeada de sus nietos, les hace cuentos noche tras noche. Se trata de un trabajo metaficcional, ya que la escritora desde él se refiere a uno de sus textos poéticos: "las interesantes historias que les relata, las cuales quedarán grabadas indeleblemente en la memoria del infantil auditorio, y formarán más tarde una parte del poema que tiene por nombre Recuerdos de la infancia" (284). Pero lo más importante de este título es el lugar que da a la mujer como eje en la formación de la familia, que es su motivación: 
Así bajo la dulce influencia de la abuela, comienzan

á germinar sentimientos de aquellos sensibles

corazones. Son las primeras lecciones morales; el alfabeto donde empiezan a conocer los principios y máximas que han de guiarlos en la vida. La madre coadyuva á la difícil tarea, haciendo respetable y venerada la autoridad de la abuela. Siempre que llega la ocasión, dice á los niños: - ¿No recordais lo que os ha contado vuestra abuela? ó bien: -Es menester hacer lo que ella os aconseja. De esta suerte es acatada la autoridad de la anciana, que comparte con la madre la soberanía de la familia. $(286)$

Una vez más el tema de la mujer, elevado al rango de centro de la familia y educadora de futuras generaciones. Un papel, por cierto, donde el hombre sólo aparece como niño en formación, pero está ausente en la enseñanza que han de recibir los nuevos descendientes.

En "El vendedor de periódicos," trata la marginación, tema frecuente en el romanticismo. En este relato hay como en prácticamente todos los trabajos de Kruger, la búsqueda de una enseñanza. Pinta la autora a un niño de doce años que vende periódicos en el Parque Central de La Habana. El párrafo más 
notable resulta una ironía, una intención, donde se afirma: "La civilización, es decir, el triunfo de lo bello y de lo bueno, por medio de la Prensa, su propagadora más culta y refinada, iba como un sarcasmo, en los brazos de la ignorancia y el abandono" (298) .

Rosa Kruger vivió poco. De su vida no se sabe mucho, pero bastan sus proyecciones y sus logros, los cuales, más allá de sus intenciones, nos hablan de una mujer que luchó contra los prejuicios de su época. No expresó directamente sus ideas como lo hiciera la Avellaneda, Adelaida del Mármol, Aurelia Castillo o, alguna vez, Luisa Pérez de Zambrana, pero el hecho de cultivarse, de escribir, publicar y traducir, la colocan muy lejos de la imagen de la mujer dedicada exclusivamente al hogar y mirada por su sociedad como un ser incapaz de pensar y de exponer su sentir. Esto, por sí sólo, constituye una avanzada y la pone, como ser intelectual, a la par del hombre de su tiempo.

\section{Sofía Estévez y Valdés ${ }^{99}$ de Rodríguez.}

Nació en Puerto Prícipe, hoy Camagüey, en septiembre de 1848. Murió en La Habana el 5 de marzo de 1901. Usó el seudónimo Hija del Indio Bravo. Gracias a los "Apuntes biográficos" de J. Delmonte G. (sic.), sabemos que sus 
primeros años los vivió en la capital de su provincia. Luego, por reveses en la fortuna paterna, se vio obligada a trasladarse a una finca cercana a su ciudad natal, antes de lo cual ya leía desde los cuatro años guiada por su madre. Ésta le enseñó la cartilla, la tabla de cuentas, a "escribir [...] [y a] coser" (VIII) y a su vez la instruyó en los principios religiosos. Delmonte dice que era tal su talento que "ántes de los nueve años, y sin haber pisado los umbrales de ninguna escuela, había ya completado su educación primaria elemental" (VIII). En el campo, Sofía Estévez se vio cercada por la naturaleza que amaba. En el trozo de una carta que hizo a una amiga afirmó:

No me conformo con admirar y comprender todo lo que aquí me rodea; quiero más; quiero expresarlo, pero no de una manera vulgar, sino en un lenguaje dulce y conmovedor,...... ${ }^{100}$ lenguaje que ni yo misma conozco...... Y este deseo, cuya realización miro imposible, me atormenta y aflije. Es una secreta y constante lucha empeñada entre mi corazón y mi insuficiencia, que me abate, haciéndome llorar de pena! (cit. en Delmonte IX)

Por esos tiempos la única literatura que le llegaba eran los poemas que se publicaban en los diarios y los cuales, 
según Delmonte, no eran de la mejor calidad. En uno de ellos, El Fanal, vio la luz su primera composición poética. Corría el año 1864 y contaba Sofía Estévez con dieciséis años, cuando visita brevemente su ciudad. Entonces se le invitó a una tertulia literaria, y asistió en una sóla ocasión en la cual leyó un texto, "A mi pátrial01." Causó tan buena impresión que al día siguiente le obsequiaron varios libros, entre ellos uno de las poesías de Garcilaso de la Vega y, a la vez, un licenciado publicó en El Fanal un artículo en su elogio. Posteriormente retornaría a la soledad de sus campos. En 1866, dos años después, sus padres deciden el retorno definitivo. En agosto del mismo año concibió el proyecto de publicar un periódico semanal donde colaborara "el bello sexo," que tuvo gran significación en los anales de la prensa cubana pues fundó y dirigió El Céfiro (1866), en unión de otra infatigable luchadora del periodismo femenino, Domitila García de Coronado (1843-1937) (Max Henríquez I: 338). El Céfiro salió por primera vez en octubre de $1866^{102}$ y desapareció dos años después al comenzar, el 10 de octubre de 1868, la Guerra Grande o Guerra de los Diez Años. En el ejemplar más antiguo que se ha encontrado -19 de abril de 1868- aparece el siguiente subtítulo: «Periódico literario, de modas, costumbres y semi-oficial de la Sociedad Popular de Puerto 
Príncipe dedicado a sus socios,» (Diccionario 1: 209). En él se editaron trabajos en prosa de interés para la mujer así como narraciones, firmados por Juana de P., Luisa Jiménez, Elvira, Rufina, La Guayabera, La Yumurina, entre otras. La misma Sofía Estévez publicó allí sus novelas en forma de folletines: Alberto el trovador y Doce años después. Domitila García se alejó del periódico dos meses después de fundado. Por el Diario de la Marina, correspondiente al 15 de febrero de 1867, se sabe que se separó, desde el número 13, "por causas ajenas a su voluntad" (cit. en Diccionario. Vol 1: 209). Por la misma García de Coronado conocemos que "la empresa tuvo una acogida entusiasta en toda la Isla" (175). Hasta su desaparición, Sofía Estévez fue quien estuvo encargada de su redacción junto con algunas colaboradoras. Tal fue el éxito de sus ensayos que se reprodujeron por casi todos los periódicos de la isla y algunos de la península (Delmonte X). A su vez, esto la convirtió en Socia de Mérito de las sociedades que existían en Puerto Prícipe y en algunos otros pueblos de la isla.

Sofía Estévez se unió posteriormente a los mambises en los campos revolucionarios, compartió con ellos sus privaciones y así se expuso a los peligros de la guerra; es en la manigua donde escribe sus inflamadas estrofas "A Cuba ${ }^{103 "}$ 
(Remos, Historia II: 458). Luego de su matrimonio, según Vicentina Elsa Rodríguez "con Manuel Rodríguez [...] capitán de la guerra de 1868" (121) y a causa de la actitud separatista mantenida por ella y por su esposo, vivió expatriada en Key West, Estados Unidos, lugar en el cual según Rodríguez "levantó el hogar arrancado de su tierra y él fue asilo para los necesitados" (121). Después de muerto su cónyuge en los campos de batalla de Cuba la misma Rodríguez afirma "regresó a Camagüey y ocupó en la manigua el puesto que la muerte del Capitán Rodríguez dejara vacante" (122) .

Rocasolano, quien no tuvo acceso a Lágrimas y sonrisas, y sólo analizó algunos poemas encontrados en las antologías de González Curquejo y García de Coronado, considera que "revelan una sensibilidad delicada [y] que se desenvuelven con frescura, sencillez y discreción" (119). Remos, por su parte, la llama "poetisa de espontáneos versos" (istoria II: 458). Lágrimas y sonrisas se publicó cuando Sofía Estévez contaba 27 años. Comienza con una dedicatoria de su autora al Sr. Doctor D. M. R. S., a quien llama "Mi respetable é ilustrado amigo" (V). Por la introducción se comprende que Sofía Estévez daba sus manuscritos a leer a esta persona. Le dice Estévez allí: "Sus juiciosos consejos y oportunas advertencias me han salvado, no pocas veces, de algunos 
errores y tropiezos, que con tanta frecuencia cometemos los escritores noveles" (V). Se sabe pues, que tenía plena conciencia de su labor de intelectual y que era abierta a la crítica. Según menciona después, en igual oportunidad, pensaba que tenía "escaso talento." Por lo que también expresa allí de sí misma advertimos que se consideraba un alma entusiasta y sensible que no había conocido la dicha ni la fortuna, salvo fugazmente; así como que llevaba una vida de aislamiento en la "soledad de las selvas" (V). Soledad en la cual afirma, había estudiado la naturaleza. Todo esto lo hace para referirse a la primera parte del título de su poemario (Lágrimas), donde observamos un afecto triste y, a su vez, el contacto con lo bucólico, motivos que estuvieran tan presentes en el territorio poético del romanticismo. Pero luego del sufrimiento, como un arcoiris, opina, siempre aparecen las sonrisas, que incluyen la segunda parte de su título (sonrisas)

Después de las palabras de la autora aparecen las que llevan por nombre el de la misma ("Sofía Estévez Valdés"), que firma J. Delmonte G., quien considera que en "sus cantos rebosa la ternura de la más esquisita sensibilidad" (VII). Este crítico, que agrega una biografía breve de Sofía Estévez, 
indirectamente expone la situación de la mujer hacia 1875, año de la publicación:

cuando el personaje de que se ocupa no ha sido de aquellos que han figurado en los grandes acontecimientos de la política de las naciones, ni influido de algun modo en los destinos de la humanidad, porque ha pasado los días de su vida en el retiro doméstico, entregada al cultivo agradable de las bellas letras, suele parecer frívola y aún trivial la narración biográfica, á muchos, y sobre todo, á espíritus que no toman en consideración el ejemplo edificante que para la juventud ofrece con frecuencia la vida particular de individuos que han enriquecido la literatura con frutos de su inteligencia, y la moralidad de las costumbres con las virtudes de su corazón (VII), (énfasis nuestro).

En resumen, se habla en este párrafo del "ángel del hogar," es decir, de la mujer que para estar de acuerdo con la moral y las costumbres de su tiempo, tenía su sitio en la casa y no jugaba papel alguno en los destinos de su pueblo. Destino que en las sociedades patriarcales, estaba, y aún está, en un por ciento altísimo en manos del hombre. Por no salir de la América hispana y del siglo cuando se escriben estos 
criterios, pensemos en Benito Juárez o en Simón Bolívar. Ellos sí merecerían biografías llenas con sus acciones, pero ¿qué decir de alguien del sexo femenino? Luego Delmonte continúa hablando de Estévez y sigue usando los adjetivos propios de su época y de su sociedad. Para referirse a ella emplea los consabidos "pureza de sus sentimientos," y la "generosidad de sus afecciones," así como "las dulces emociones de su alma" (VII) .

El título Lágrimas y sonrisas, está tomado de un poema que es el último del libro, donde se encuentra un afecto ambiguo. Tiene la dedicatoria "A Luisa," y en él su autora habla en segunda persona:

No me preguntes qué siento

Cuando tan triste me veas,

Pues lo que saber deseas

Es lo que me dá tormento.

Si todo mi pensamiento

Mostrarte claro pudiera,

En él tu pecho leyera

Lo que yo en el mio sepulto,

Y que mejor está oculto

Que si yo te lo dijera. (160) 
No se aclara durante el resto de las siete décimas qué oculta Sofía Estévez ni qué desea saber Luisa. Pero por lo expresado puede inferirse que es algo muy serio, un tema muy delicado, como para que en los últimos versos de la segunda décima se diga que se está muriendo por lo que se reserva:

$$
\begin{aligned}
& \text { Verás en mí la impresión } \\
& \text { De una tristeza profunda, } \\
& \text { Me verás meditabunda, } \\
& \text { Y silenciosa,.... y sombría; } \\
& \text { ¡Mas, no sabes, Luisa mia, } \\
& \text { Que casi estoy moribunda! (160) }
\end{aligned}
$$

Esta ambigüedad anterior se manifiesta más tarde en "Contraste," poema en el cual la poeta mantiene un debate consigo misma entre lo que se considera "bien" y lo que es visto como "mal." La primera estrofa comienza hablando de su pureza y de su candidez como un velo:

Ciñe mi frente pálida aunque pura

De la honradez la fúlgida diadema, Tras el velo de cándida ternura Que es de virtud y de pureza emblema. (68) Nunca se explica, como tampoco en "Lágrimas y sonrisas," a qué se refiere Sofía Estévez, o cuál es la etiología de sus cuestionamientos y por qué muestra ante los otros, y ante ella 
misma, ese "velo de cándida ternura." En "Al caer la tarde," se desnuda en sus reflexiones y nos aclara discretamente el significado de los anteriores versos:

El bullicio del mundo

$$
\text { Me aflige y mata; }
$$

La soledad del campo

Solo me es grata;

Porque, ioh, tormento!

Me hace fingir el mundo

Lo que no siento. (93)

Tres estrofas posteriores a la que ya analizamos de "Contraste," señalan:

Y sin embargo, en mi abatida frente

Pálida y triste cual marchito lirio;

Tras la diadema de virtud fulgente

Brilla también la aureola del martirio. (68)

En la penúltima estrofa de "Contraste," uno se pregunta si el abismo que se descubre en Sofía Estévez tiene que ver con lo que tiene oculto, y muy sepultado en sus sentimientos hacia Luisa, a quien ha dedicado el poema, que además da nombre al poemarioy, por ende, es el poemario mismo:

Y hay en mi corazon... no sé qué cosa... Hacia el bien,.. y hácia el mal á un tiempo mismo... 
Pero, me dice el alma sentenciosa

« ¡Do muere el bien, descúbrese el abismo!» (69)

¿Será lo anterior expresión velada de un sentimiento prohibido para su época que la lleva también a escribir su "Tempestad," en cuyos versos se iguala la borrasca exterior con la que recorre su espíritu? Sofía Estévez le habla en este poema a las sombras:

$$
\begin{aligned}
& \text { Noche lúgubre y horrible } \\
& \text { Que bien espresas sin calma } \\
& \text { La congoja indefinible; } \\
& \text { La tormenta, que terrible } \\
& \text { Siento rugir en mi alma. (117) }
\end{aligned}
$$

Esta congoja recorre su obra atormentada. Sabemos que se marchó de Camagüey, tierra que amaba, para irse a La Habana. En medio del siglo XIX, esta mujer, isola!, viaja a la capital de su país, para luego cantar:

$$
\begin{aligned}
& \text { ¡Sin parientes, sin bienes, sola y triste, } \\
& \text { Débil juguete de la suerte vária,... } \\
& \text { En los brazos, que tierna me tendiste, } \\
& \text { Todo lo hallé ioh Habana hospitalaria! (23) }
\end{aligned}
$$

No se conocen los motivos ni por su breve biografía ni por su obra. Pero sufre mucho al despedirse, y luego, en la 
distancia. Lo refiere "En una ausencia." Los últimos cuatros versos de su primera estrofa recuerdan algo de aquel instante:

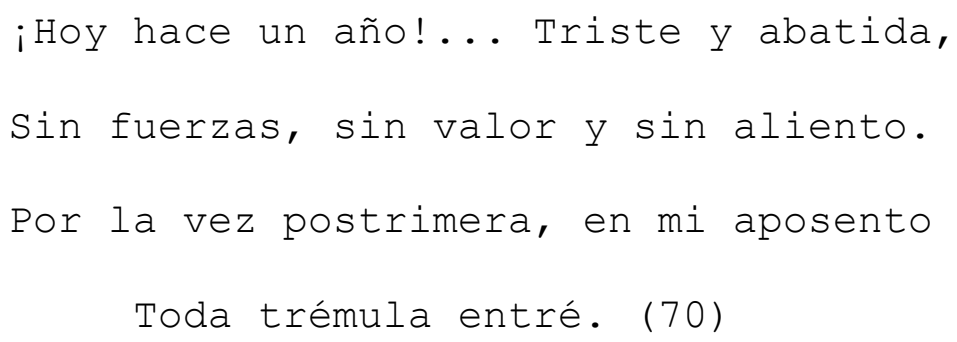


Una suya estreché.

Y ocultando mi rostro en el pañuelo,

Pidiendo á Dios conformidad y calma,

¡Con un sollozo que salía del alma,

Le dige al fin: iadios!

Por último partí.... Yo le dejaba

Al Camagüey mi amarga despedida;

Despedida no era.... ¡Fue mi vida

La que en él se quedó! (72)

Hace un año que ha partido; de quienes la despiden, en Camagüey, sólo queda un nombre: Luisa. Si sabemos que allí deja su vida. ¿Qué sacó a esta joven y emocionada poeta de su amada ciudad? No se sabe, pero hay otros poemas donde posiblemente esté parte de la solución del enigma. En "La virtud," un texto que tiene como dedicatoria: «A Lina», donde le ofrece unos consejos que sólo pueden darse cuando se tiene experiencia de la vida, en la tercera estrofa quizás se encuentre, indirectamente, el motivo que la lanza lejos de su tierra natal:

$$
\begin{aligned}
& \text { Desprecia el dulce veneno } \\
& \text { Que el mundo en copa de oro } \\
& \text { Ofrece entre risa y lloro }
\end{aligned}
$$



A la incauta juventud;
Y no te importe que el vulgo
Murmure á su antojo y diga...
Mientras tu alma prosiga
Practicando la virtud. (132-133)

La última estrofa concluye con similares consejos:

$$
\begin{aligned}
& \text { ¡Escucha sin inmutarte } \\
& \text { De la calumnia los tiros; } \\
& \text { Y entre férvidos suspiros } \\
& \text { Besa del Señor la cruz! } \\
& \text { Y deja al mundo que hable... } \\
& \text { iQue siempre, mi tierna Lina, } \\
& \text { Brillará la luz divina } \\
& \text { De tu angélica virtud! (133) }
\end{aligned}
$$

Parece ser que Sofía Estévez sufrió las calumnias del vulgo en aquel siglo decimonónico, donde le fue difícil convivir y por eso se aleja para seguir derramando su tristeza, pero consolándose con su religión. ¿Acaso sintió un amor homoérotico por Luisa que, dada sus crencias y la crítica de una sociedad mojigata, la hicieron debatirse y por eso prefirió retirarse?

Quizás por ello en "A Dios," pide por ella y por los pecadores y se le observa un instante, aunque breve, de duda: 
Mas, no, Señor,..... que sin dudar revelo

Cuando así hablo al salvador del mundo,

No es duda no, no,.... porque seria delito

Dudar de quien es Dios.... iDios infinito!

Refleja incertidumbres porque en este poema hay un enfrentamiento, aunque discreto, con la divinidad. Existe en ella una pugna interior entre sus conceptos de pureza del alma y su deseo amoroso. ¿Acaso sentimientos de culpa frente a la dicotomía entre el bien y el mal que le impuso la religión de su tiempo y por ende su sociedad?

No nació malo el hombre; inteligencia

Clara le diste para el buen camino; $[\ldots \ldots \ldots \ldots \ldots \ldots \ldots \ldots \ldots \ldots \ldots \ldots \ldots$

Mas,.... ison tus hijos! Buenos los hiciste, Aunque en el vicio vivan olvidados

De que tanto por ellos padeciste!

No permitas que vivan extraviados

Los que tú con tu sangre redimiste!

¡Haz que á tus pies, volviendo contristados,

Merezcan otra vez tus bendiciones.

Y no á su perdición los abandones. (143)

Es posible que creyera que estaba cometiendo un hecho pecaminoso y por eso se aferró a su fe. Religiosidad, reflejo 


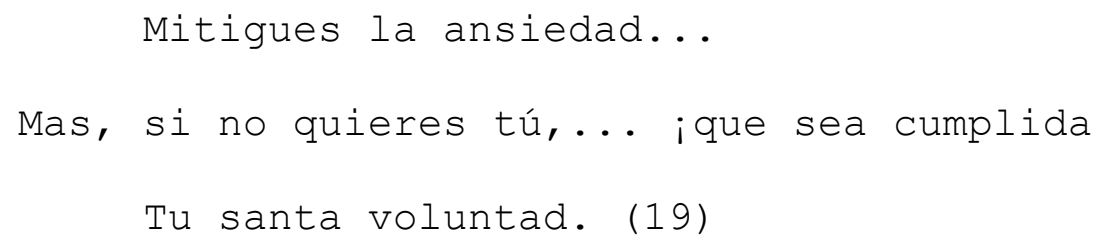


eternamente de la compañía paternal: "¡Donde tuvo mi padre sepultura, /Quiero tambien la sepultura mia!" (24) .

"A mi padre," dedicada también a su progenitor, escrita en $1871^{104}$, narra los contrastes entre su niñez y la vida que transcurre en el momento que compone:

$$
\begin{aligned}
& \text { En infantiles ilusiones bellas } \\
& \text { Miraba por do quier rosas divinas; } \\
& \text { ¡Mas no pensaba que pudiesen ellas } \\
& \text { Guardar serpientes y tener espinas. (34) }
\end{aligned}
$$

A los 23 años, Sofía Estévez despierta al mundo. Madura, decepcionada de que se rompiera su "apacible infancia" y la "dulcísima ignorancia" en la que vivía. Ya no es más la cándida muchacha que soñaba, y disfrutaba, en la soledad de sus campos camagüeyanos:

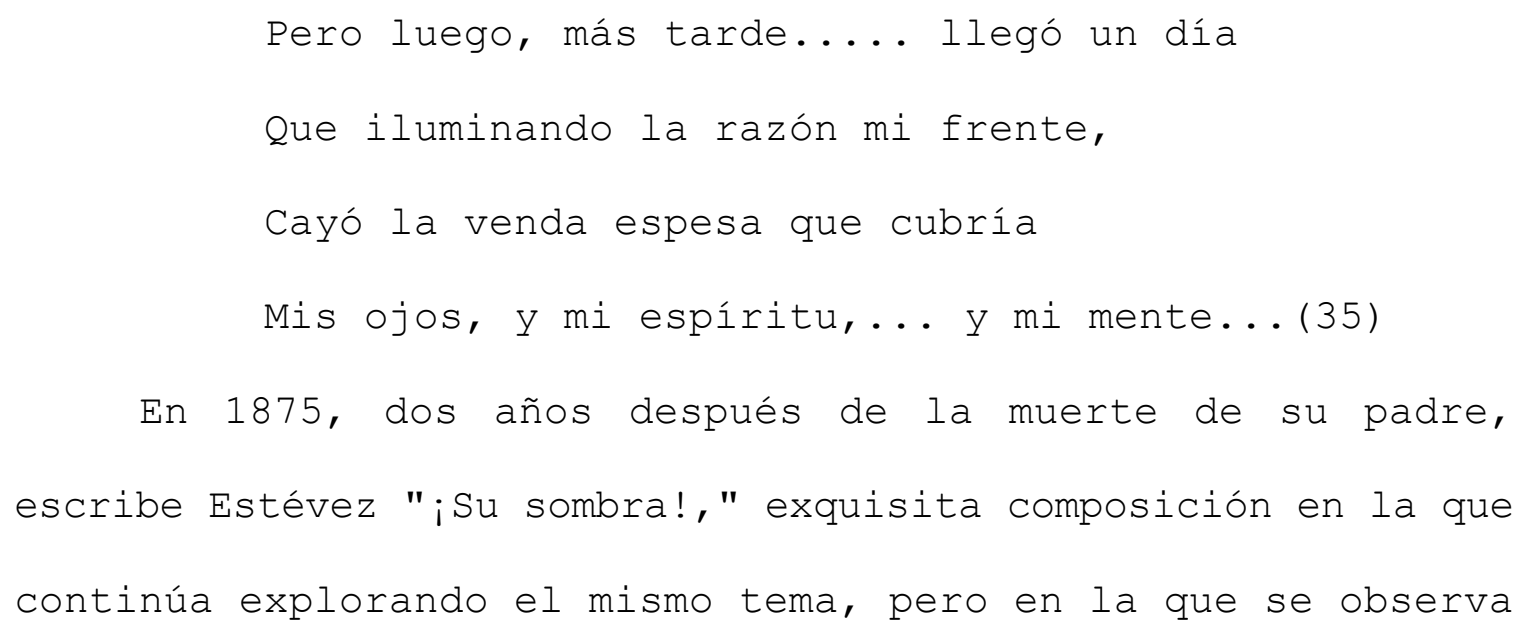
ya la resignación:

¡Oh sombra de mi padre, bella sombra! 
¿Es ilusión, ó levantarte miro

Sobre la verde y perfumada alfombra?

Un destello de gloria te ilumina;

Tienes los ojos fijos en el cielo;

Lleno el semblante de inefable calma,

Y la actitud divina,

Cual si ya fueses á dejar el suelo!....

¿Por qué al gemir doliente de mi alma

Contestas nada más con un suspiro?....

¡Si es que imploras del mundo en que resides,

En cambio de tu amor, mis oraciones,....

También yo de rodillas iay! te pido:

¡Vela siempre por mí, padre querido!....

¡Padre del corazón,..... no me abandones! (111)

Este pedido de ser cuidada, de no ser dejada a la deriva, proyecta los sentimientos de la autora. Así lo demuestran algunos de sus títulos: "Sin porvenir" "Anhelo," "Quién sabe," "Imposible," "La esperanza y el temor," "Desencanto," y "¡Ay.....!" entre otros.

Los versos de "Quién sabe" enseñan cuál era generalmente su estado de ánimo. En su séptima estrofa afirma:

Cuando triste y abatida

Vi mi esperanza acabada, 
Y mi dicha convertida

En humo... en espuma... en nada...(31)

Y continúa en la doce:

$$
\begin{aligned}
& \text { ¿Quién sabe! -tan solo puedo } \\
& \text { Decir, aunque me disgusta, } \\
& \text { Pues el presente me asusta } \\
& \text { y el porvenir me da miedo. (32) }
\end{aligned}
$$

En la última estrofa, hay abulia, una inercia de pensamiento; la aceptación de un destino del cual no se puede escapar; presencia del hado que es también romántica:

¡Quién sabe si el pecho herido

Nuevas lágrimas encierra....

Ay! porque yo no he nacido

Para gozar en la tierra! (33)

En "Imposible," se sigue leyendo ese desasosiego, ése no poder entender claramente qué emociones la embargan, qué rumbo seguir, tema que se reitera constantemente en Sofía Estévez: ¿Qué es lo que siento ¡oh Dios! qué es lo que siento En el fondo del alma...?

¿Qué es este fijo y triste pensamiento Que me roba la calma, Que la razon domina, Y á una tristeza sin igual me inclina? (N. pág.) 
Quizás este desencanto, en el que se busca a la divinidad, esté dado por la imposibilidad amorosa, cuando la única vía que pudo seguir fue la de su fe. En los tercetos de "Soneto105" -"Pasan los bellos, cándidos ardores"- la poeta expone esos amores desdichados que acompañan al movimiento del cual forma parte:

Apágase cual rayo vespertino

La ilusión del amor que falso halaga,

Y pasa en fin, cumpliendo su destino

Todo en la tierra, cuanto más embriaga;

Solo la fé cristiana, astro divino

Ni pasa nunca, ni jamás se apaga! (40)

Lo marginal también desfila por su lírica. Poemas como

"El bastardo," "La joven indigente" y "El mendigo" lo atestiguan. Como es frecuente en ella, varios temas confluyen en un mismo espacio poético. Así en "El bastardo," la tristeza se mezcla con la naturaleza, reflejo de su perenne estado de ánimo. Éste es un texto en contra de una mujer que ha abandonado a su hijo espurio. Versos como !Madre cruel!... pecho de hiena" (43), "Alma innoble, envilecida" (44), pone la autora en boca del protagonista. Sin embargo, sólo se culpa a la mujer. En ningún verso de la composición, que tiene veinte y cinco cuartetos, se habla del padre. El reflejo de las 
emociones del bastardo, en la naturaleza, se halla en la tercera estrofa:

$$
\begin{aligned}
& \text { Mústias se inclinan las flores } \\
& \text { Al fijar mi vista en ellas, } \\
& \text { Y hasta el sol y las estrellas } \\
& \text { Me niegan sus resplandores. (41) }
\end{aligned}
$$

Las lágrimas, presentes en todo el poemario desde el título y que sólo muy ocasionalmente se acompañan de sonrisas, se hallan incluso en momentos de alegría. En "Una promesa a Nuestra Señora de la Caridad," dice Sofía Estévez a la Virgen:

Mírame aquí; postrada estoy de hinojos

Ante tu imágen celestial y pura;

Mira el llanto que brota de mis ojos Llanto de gratitud. (46)

Hay hiperbolia en sus emociones, pero la poeta se regocija en ellas, disfruta de su intensa subjetividad y es amiga de su llanto. En "Lágrimas" lo expresa:

Si tanto me agovian mis penas sombrías

si un triste silencio me mata el pesar,

Venid á mis ojos ioh lágrimas mias...

Quemad mis megillas; que os sienta rodar! (144)

Amiga de la soledad y del soliloquio íntimo, sin embargo no deja de hacer referencia a la relación amorosa. Hay un 
poema donde se nota un afecto alegre. "La vida es amor," presenta una Sofía Estévez feliz que se sale de sí misma para fijar su mirada en el paisaje que la rodea y compenetrase con él :

El sol que despide sus rayos divinos,

El cielo vestido de hermoso color,

El bello paisaje que admiran mis ojos

Parecen que dicen: ila vida es amor! (50)

En el resto del texto se habla de árboles, flores, aves, monte, tierra y aire. La palabra amor finaliza los siete cuartetos de la composición. Es una de las pocas "sonrisas" de su libro. El último verso explica por sí solo el porqué de tal epifanía: "¡Dichoso quien ama!... ¡La vida es amor!

La patria está también presente en su obra, como hemos mencionado, en poemas desaparecidos hoy. Por su independencia fue capaz de ir a los campos de batalla y de vivir en el exilio, pero no es lo que llena su versificación. La melancolía, en todas las vertientes, es la que fluye de sus páginas como si hubieran sido escritas de una sóla vez en el más triste de sus días. Salvo alguna cita de colón y de Homero, no se refleja en ella gran erudición aunque sí dominio de la rima, especialmente del soneto y de la décima. Los motivos fúnebres y sepulcrales no son, sin embargo, tema 
único; hay siempre esbozada, aunque de una manera leve, la sonrisa que anuncia el título, así como la ternura del recuerdo hacia sus familiares y amigos, hacia los paisajes que rodearon su infancia, y hasta para La Habana, que la recibió. Todo dicho con tan suave lirismo que hace, por momentos, olvidar el tormento y sus lágrimas, para reflexionar sobre las causas que la llevaron a escribir poesías tan dolorosas.

Sofía Estévez fue sobre todo una intelectual de su tiempo con plena conciencia de la guerra de independencia de su patria por la que luchó. Buscaba, además, con su trabajo lidiar por la mujer como lo muestra la fundación de un periódico que salió hasta que la guerra de independencia estalló en su suelo. Pero también demostró, en su canto, cuán consciente estaba de su labor literaria y de lo que deseaba hacer para alcanzar la posteridad. Lo afirma en "A un amigo," uno de sus diversos textos dedicados a la amistad:

No importa nada.... La razón me dice

Que oiga solo la voz de mi conciencia,

Y aunque sea miserable la existencia,

Prosiga con valor.....

Amo la gloria; y entusiasta y firme

Quiero buscarla con creciente empeño;

Que son los láuros mi dorado sueño: 
La fama, mi ambición!

Y si llega á cumplirse este deseo

Que incesante se agita en mi memoria,

Y en el libro sublime de la historia

Mi nombre llego a ver;

Al desprenderse de mi cuerpo el alma

De mi gloria veré la ardiente estrella,

Y aquella noche que me hablaste de ella

Feliz bendeciré. (155)

Hasta aquí hemos visto a una creadora que rompe con el esteriotipo y los cánones que existían sobre las mujeres de su época. Seres que desde la mirada patriarcal debían dedicarse a sus hogares. "Romance," es un poema que refleja su lucha contra esta situación. Los primeros cuatro versos se refieren a un ave, "tortolilla" la nombra la poeta en un tono de lástima, que vive "Entre la espesa montaña/Que sufre dolor profundo y por consolarse canta" (N. pág.). Recordemos que las aves son símbolos de libertad. Los versos once y doce dicen: "¡Mas son áves... y son trinos.../Y el mundo no dice nada! (55). Luego es un hombre, quien se queja "de la cruel que lo olvidára" (55). Es muy interesante para este estudio el resto 
del poema. Los versos, que ahora se refieren al hombre, son los que siguen:

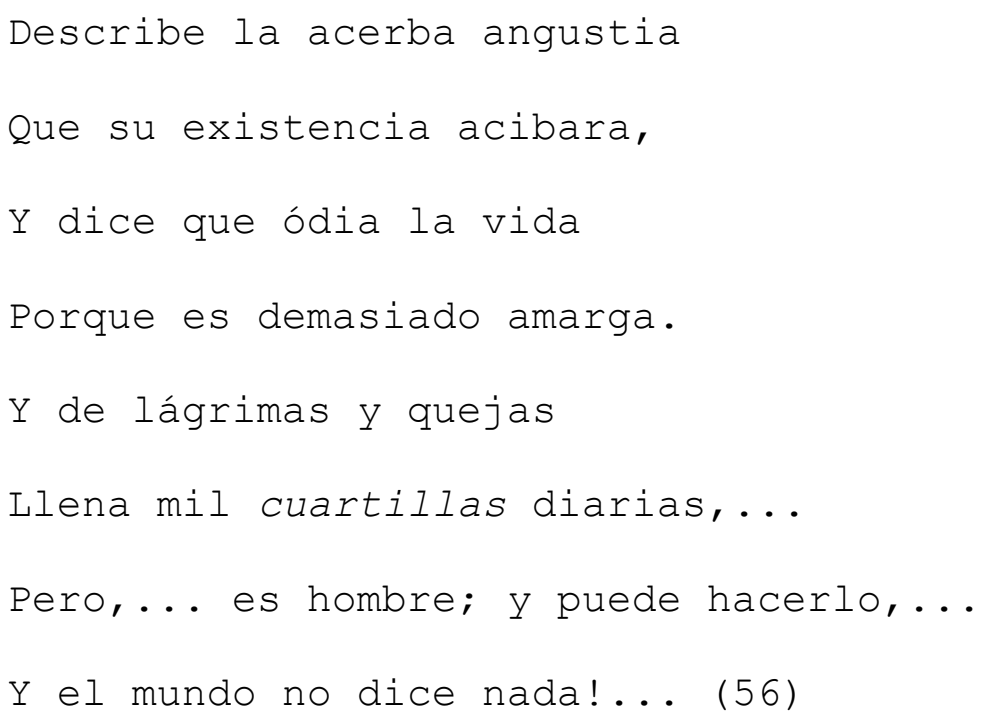


Es lo que ha venido haciendo, incluso en este romance con cuyos versos demuestra cuán consciente estaba Sofía Estévez del papel que le tocó jugar a ella y a sus compañeras de generación y de siglo:

Mas porque así me lamento

El mundo murmura y habla; ...

¡Soy muger,... y me condena!

¡La muger, no puede nada! (56), (énfasis nuestro)

Con su vida y su obra, Sofía Estévez demostró que la mujer sí podía triunfar, aunque esa lucha les tomaría mucho más tiempo del que ella y sus coterráneas seguramente pensaron.

Max Henríquez Ureña cree que Doce años después y Alberto el trovador son de escaso valor (I: 338). Este último título aparece mencionado además por Rocasolano. Juan J. Remos, incluye a María, y las describe como relatos novelescos (Historia II: 459). Texto que también toma en cuenta Rocasolano. 


\section{Catalina Rodríguez Martínez de Tardiña.}

Llamada Catalina Rodríguez de Morales, después de 1866, cuando contrajo matrimonio con el botánico Sebastían Alfredo de Morales ${ }^{106}$, nació en Pipián, Madruga, provincia de la Habana, el 26 de marzo de $1835^{107}$ ? y murió en Villa Clara el 14 de noviembre de 1894. Utilizó el seudónimo de Yara. Perteneció a las secciones de literatura de las sociedades Recreo de Pueblo Nuevo y Liceo de Matanzas, de la cual fue socia de mérito. Fue, además, directora del periódico quincenal El Album (Matanzas, 1882). Y colaboró con La Ilustración Cubana, Cuba y América y La Moda Ilustrada de Cádiz.

Para esta investigación hemos estudiado dos de sus obras:

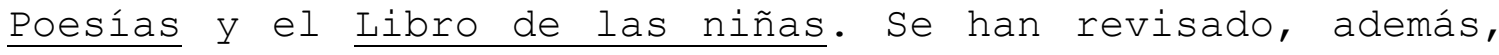
otros textos dispersos en antologías como el de Manuela Herrera de Herrera, en sus Escritoras Cubanas, de 1893, así como los escogidos por González Curquejo para el tomo II de su Florilegio de Escritoras Cubanas, de 1913, y los poemas presentes en el estudio de Rocasolano. Catalina Rodríguez también escribió obras de teatro.

5 a. Poesía.

Desde muy pequeña se aficionó a la poesía. González Curquejo señala que era "hija de un médico ilustre y amante de la poesía; el que influyó en la decidida vocación" (II: 167). 
Se trasladó con su familia a La Habana aproximadamente a los quince años ${ }^{108}$. Luego su padre se estableció en Matanzas, donde Catalina Rodríguez recibió en 1865 un premio ${ }^{109}$ por su oda "Al trabajo" en los Juegos Florales del Liceo de esa ciudad. Texto que elogió el sabio Felipe Poey en el prólogo de su primer poemario -1866-, y de Herrera de Herrera en Escritoras cubanas, en 1893.

"Al Trabajo," es un largo poema que consta de sesenta y una octavas reales. Cuatrocientos ochenta y ocho versos, dividido en dos cantos. El primero de 27 estrofas, el segundo de 34. Esta extensa composición celebra la laboriosidad, -desde la de Dios hasta las de la fauna y la flora-, y muestra, además, la erudición de su autora. Se habla en él, entre otros temas, de inventores norteamericanos, ingleses y franceses; de dioses y personajes latinos, griegos y bíblicos; de antiguas ciudades europeas y africanas; de pintores renacentistas y de escritores antiguos. Es peculiar su uso de la jota, como mucho después lo haría Juan Ramón Jiménez; nunca, tampoco, utiliza la y griega posible influencia catalana o gallega, lenguas que no usan esa letra. Resalta también en este trabajo, la naturaleza y su religiosidad. Todo lo anterior puede verse en los siguientes versos ¡Gloria á Fulton! Su barco prodijioso 
El seno atravesó del mar rujiente,

I pintor i mecánico afanoso [...] (129)

$[\ldots \ldots \ldots \ldots \ldots \ldots \ldots \ldots \ldots \ldots \ldots \ldots \ldots$

\section{]}

¡Salve mil veces al Trabajo honroso

Por el Sumo Hacedor santificado! (132)

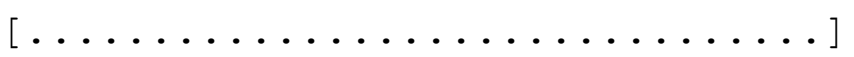

Harto alabé de mi pasión llevada

La tórtola que jime en la espesura,

I la bella azucena perfumada

Que ostenta en el arroyo su blancura [...]

$[\ldots \ldots \ldots \ldots \ldots \ldots \ldots \ldots \ldots \ldots \ldots$

¿Quién guió con su mano la pintura

Del dulce Rafael? ¿Quién dió al profundo

Miguel Anjel ayer la mano pura

Que ardiera en su cerebro sin segundo? (135)

(Énfasis nuestro)

Hacia el final el poema canta a la patria y nombra a dos poetas griegas con las que desea compararse:

Cuba, tierra de amores venturosa,

Hija del seno del fecundo Atlante

Que los besos recibes cariñosa

De los labios del Febo fecundante [...] (141)

$[\ldots \ldots \ldots \ldots \ldots \ldots \ldots \ldots \ldots \ldots \ldots \ldots \ldots$ 
Si cual Safol10 o Corina yo pudiera

La cítara ataviar con cuerdas de oro,

Ardiendo en gloria á la celeste esfera

Elevara mi cántico sonoro; (142)

Este amor patrio se observa también en "Ansiedad" donde, además de la erudición que hemos señalado anteriormente -aquí menciona nuevamente varias geografías y a sus grandes hombres y mujeres- muestra deseos de viajar por el mundo. Finalmente compara todos los paisajes con el de su tierra para afirmar:

$$
\begin{aligned}
& \text { ¡O lengua atrevida, calla! } \\
& \text { Déjame, bajel; lijero } \\
& \text { parte tú á tierras extrañas, } \\
& \text { Que yo en mi suelo querido, } \\
& \text { Al susurro de las palmas, } \\
& \text { Exhalaré la existencia: } \\
& \text { Quiero morir en mi patria. (11 } 111 \text { ) }
\end{aligned}
$$

Se supone que es en el año 1865 cuando Catalina Rodríguez inició la publicación de sus versos. Su primer libro poesías se edita un año después. El texto que lo inicia: "Inspiración," resulta metapoético; posee también versos donde están presentes rasgos depresivos, característicos de la época :

Cuando de infaústos rayos coronada 


\section{Llega á mí la amargura,}

Hija del cielo, en mi fatal tristura

A tí vuelvo los ojos desolada,

$$
\text { Que en tus carmíneos labios }
$$

Siempre encuentran las penas desagravios.

La diferencia con otras poetas es que en seguida salta Rodríguez al afecto contrario, y la epifanía disminuye el efecto de la tristeza anterior. En la estrofa siguiente que aparece en la composición leemos:

I cuando siento de inefable gozo

$$
\text { Henchido el pecho mío, }
$$

A tí el pregon de mis placeres fío;

Alzo canto de gloria venturoso:

De pláceme ó de luto

Siempre en tus aras yo rendí tributo. (2)

Después, la poeta se abandona nuevamente a sus ideas fúnebres:

Ai! me siento morir acobardada

$$
\text { Cuando una negra idea }
$$

Por mi mente de fuego se pasea:

Vendrá severa la vejez helada,

$$
\text { I entónces, alma mia, }
$$

A tí no llegará la poesía. (2) 
Aparece en ella, sin embargo, lo lúdico que caracteriza varias de sus poesías. En "Lamentos esdrújulos," aunque imita "[u]n bello romance en esdrújulo titulado: 'Lamentos de un marido,'" (98) de Juan Guillén Brozarán, según explica la misma autora, se observa tal vertiente de su poética. Este tipo de composición está ausente en las creadoras de su época y es muy escaso en la literatura en general. Sus primeros versos son los siguientes:

Dijo á su esposa frenético

De impaciencia don Jerónimo:

- ¡Válgame la corte célica,

Eres más mala que un cólico! (N. pág.)

Otras composiciones de Catalina Rodríguez manifiestan igual sentido del humor. Ocurre en "El viejo verde," donde se retratan las relaciones entre un anciano enamorado de una adolescente:

\author{
Murmura el vulgo, señor, \\ Que vos andais hecho un lince, \\ I que á una niña de quince \\ Estais haciendo el amor. \\ Diz que las noches pasais \\ Rondando su celosía \\ Hasta que os sorprende el día,
}


I de eso os acatarrais;

$[\ldots \ldots \ldots \ldots \ldots \ldots \ldots \ldots$

I cuentan que las mañanas

A las calles no salís,

Porque a esas horas teñís

Vuestras blanquísimas canas; [...] (N. pág)

En "El fatuo afrancesado," además de la vis cómica, introduce un bilingüismo galo-hispánico:

Paso, señores, que se acerca el necio,

I más lleno de viento que un molino,

Nos mira de soslayo i con desprecio.

¿Quién diseña su traje peregrino

Pasmado de los pies hasta el cogote?

$[\ldots \ldots \ldots \ldots \ldots \ldots \ldots \ldots \ldots \ldots \ldots \ldots$

Reniega de los sastres enfadado:

Sa toilette n'est pas bien, i el necio ingrato

Ni la piensa pagar, ni la ha pagado,

$[\ldots \ldots \ldots \ldots \ldots \ldots \ldots \ldots \ldots \ldots \ldots \ldots \ldots \ldots \ldots$

Sobre sus lauros ora está durmiendo.

Il est très fatigué. Permita el hado

No despierte jamás, i que este sea

El último pedante afrancesado 
Que Cuba toda entre sus hijos vea. (107)

Este tipo de poemas lúdicos esconden un sentido filosófico, de mejoramiento humano. Más que en el anterior esta tendencia se refleja en "Epístola a Elisa." Tal parece que esa joven la había criticado. Aprovecha Catalina Rodríguez su composición para responder desde su madurez y su sabiduría, pero también para hacer pensar con adultez a quien se ha burlado de ella. Representa éste uno de sus poemas más brillantes y en algunos momentos remontan a las coplas medievales de Jorge Manrique o se adelantan a la poesía posterior de Rubén Darío:

Tú lo quieres, Elisa; te has propuesto

A burlarte de mí con tal descaro

Que ya me has irritado, por supuesto.

$[\ldots \ldots \ldots \ldots \ldots \ldots \ldots \ldots \ldots \ldots \ldots \ldots \ldots \ldots$

¿Qué le encuentras de extraño á mi figura?

Yo no luzco narices de corneta,

Ni aparejo me pongo en la cintura.

$[\ldots \ldots \ldots \ldots \ldots \ldots \ldots \ldots \ldots \ldots \ldots \ldots \ldots \ldots \ldots \ldots$

Que tengas más prudencia te suplico,

Pues puede rechazar la flecha dura

I hacerle daño á tu nariz de pico;

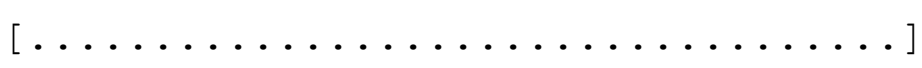


La gloria, el resplandor, todo es quimera.

Pasa la juventud, pasa la vida

I es todo presa de la muerte fiera.

$[\ldots \ldots \ldots \ldots \ldots \ldots \ldots \ldots \ldots \ldots \ldots \ldots \ldots \ldots \ldots \ldots \ldots$

Ai, Elisa, ¿qué somos, qué sabemos?

¿Qué tiempo ha de durar todo este encanto?

I en llegando la muerte, dónde iremos? (116)

Catalina Rodríguez, además, como buena romántica, en "Yo soy tu amante," se declara la apasionada del sol, de la luna, del mar, de las aves, de las flores y de una fuentecilla, como resume en la última de siete estrofas:

¡O, sábia Naturaleza,

Que derramas misteriosa

Con mano tan jenerosa

El caudal de tu riqueza!

¡Salve, salve á tu grandeza

A quien rinden mil loores

Fuentes, pájaros i flores!

I yo, que adoro constante

Pájaros, flores i fuentes,

Te doy suspiros ardientes:

Yo soy tu amante. 
El mismo amor por la naturaleza se encuentra en otros trabajos de sus Poesías, como "Contemplación," poema de nostalgia por la región donde nació y en el que muestra su conocimiento de la flora y la fauna cubanas, así como su fe religiosa. Saber que se repite en "Recuerdos en el campo," y en "Canto a Cuba," aunque en éste el canto es en general al paisaje sin las especificaciones que se advierten en los anteriores.

"Romance Indiano" itera su conocimiento de las plantas y los animales patrios y describe, además, los amores entre dos pobladores precolombinos de la isla. Llama la atención el uso de nombres indígenas. Este retroceso en el tiempo, concuerda con el romanticismo europeo y su viaje al medioevo, pero también podría significar una reafirmación del paisaje nacional ante el del viejo mundo. No se puede olvidar que la composición pertenece a su primer poemario publicado en 1866 , dos años previos al comienzo de las guerras de independencia de Cuba. Sería pues, líricamente, otro grito de emancipación desde el verso.

En "Junto al bosque," que no se encuentra en los poemas de Poesías, pero que recopiló González Curquejo, el amor a la naturaleza toma, también, un matiz filosófico como en sus trabajos lúdicos. Manifiesta aquí, como su contemporánea Julia 
Pérez Montes de Oca, una preferencia por este escenario ante el de la ciudad:

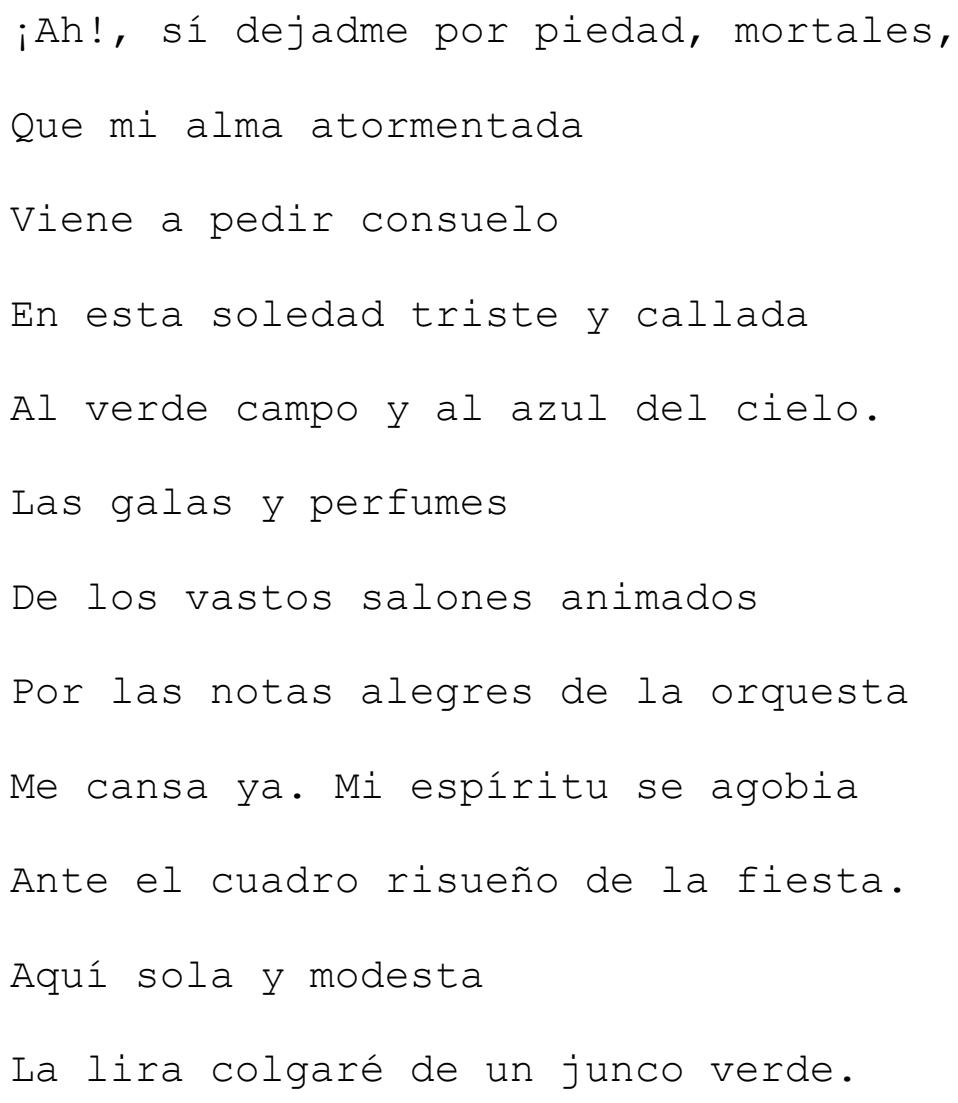


Y la danza cubana, que os convidan;

Mientras yo, divertida,

Contemplando las gotas del rocío

Me inclino a recogerlas,

Diciendo en mi interior: "¡Baste, ¡Dios mío!

De gasas y de perlas!"

Derrame el Sol su esclarecida lumbre,

Denme cantos las aves.

Su deliciosa vista el horizonte,

Sombra y hojas el monte,

La mañana su ambiente puro y suave,

Y la tarde sus tintes de oro y rosa,

Que yo seré dichosa.

Lejos muy lejos de la pompa vana

Me place a mí vivir. Yo amo las flores.

La amable sencillez, la suave calma, [...].

(González Curquejo II: 170)

Los últimos versos reflejan ideas sobre la muerte que no deben interpretarse como fúnebres. A pesar de referirse a su espíritu abatido, no ha dejado de disfrutar el hecho de la vida. Su viaje durante la composición ha sido centrífugo más que centrípeto. Es tal el éxtasis de su autora ante la 
naturaleza que aún quiere seguir allí luego de su paso por el mundo:

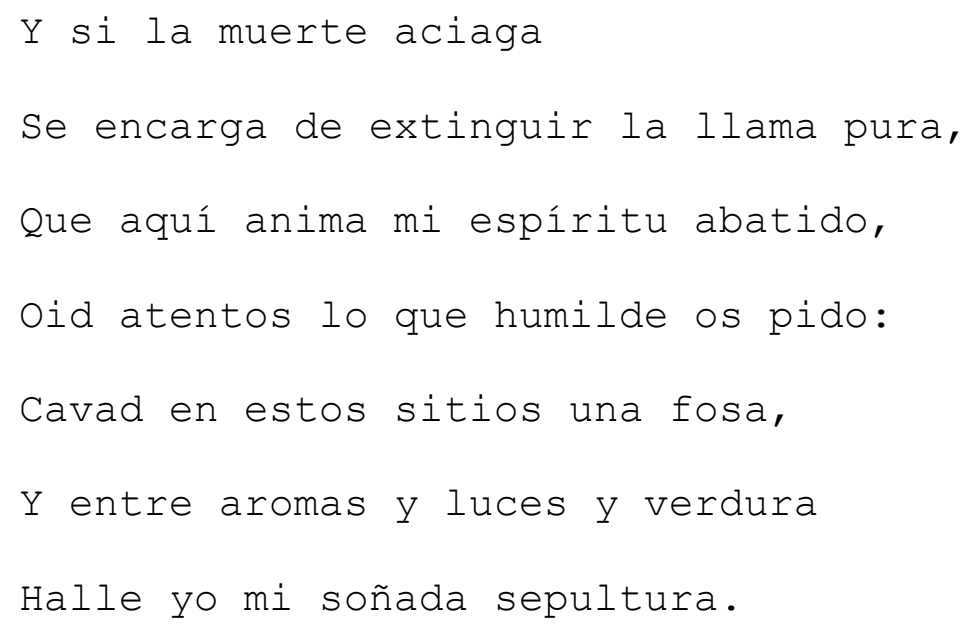


observa también en "El canto de la mendiga," texto recopilado por González Curquejo donde expone los "tormentos insufribles" de una mujer que ha perdido a sus familiares:

Mi herencia es la amargura, mis ojos son dos ríos, Mi mundo es la tristeza, mi lema es el dolor, Piedad de mis congojas, piedad, hermanos míos, Que abruman los pesares mi enfermo corazón.

(González Curquejo II: 176)

No faltan en su primer poemario, los textos dedicados a la familia tan característicos de la etapa. En "A mi madre," junto al amor materno se encuentran notas tristes por la ausencia del padre. En ésta, como en otras composiciones, Catalina Rodríguez mezcla afectos contrarios en una misma obra. El texto, indirectamente, muestra la posición social de la autora cuando, al hablar de su progenitor, dice:

En tu natal grato i bello

Yo le ví vertiendo amores

Colocar en tu cabello

Las más aromadas flores.

I oro y perlas en tu cuello. (33)

Su religiosidad, que se proyecta en varias de sus composiciones, se hace más obvia en "La iglesia," poema con ocho décimas, del que escogemos la primera: 
No sé qué májico encanto

O qué celestial dulzura,

No sé qué grata ventura

Se siente en su asilo santo:

Es consuelo del quebranto,

De la Relijion guarida,

Sacro amparo en esta vida,

Del alma mística uncion

Donde Dios á la oracion

Con suma bondad convida. (N. pág.)

También en "Noche de luna," donde en medio del éxtasis nocturno afirma:

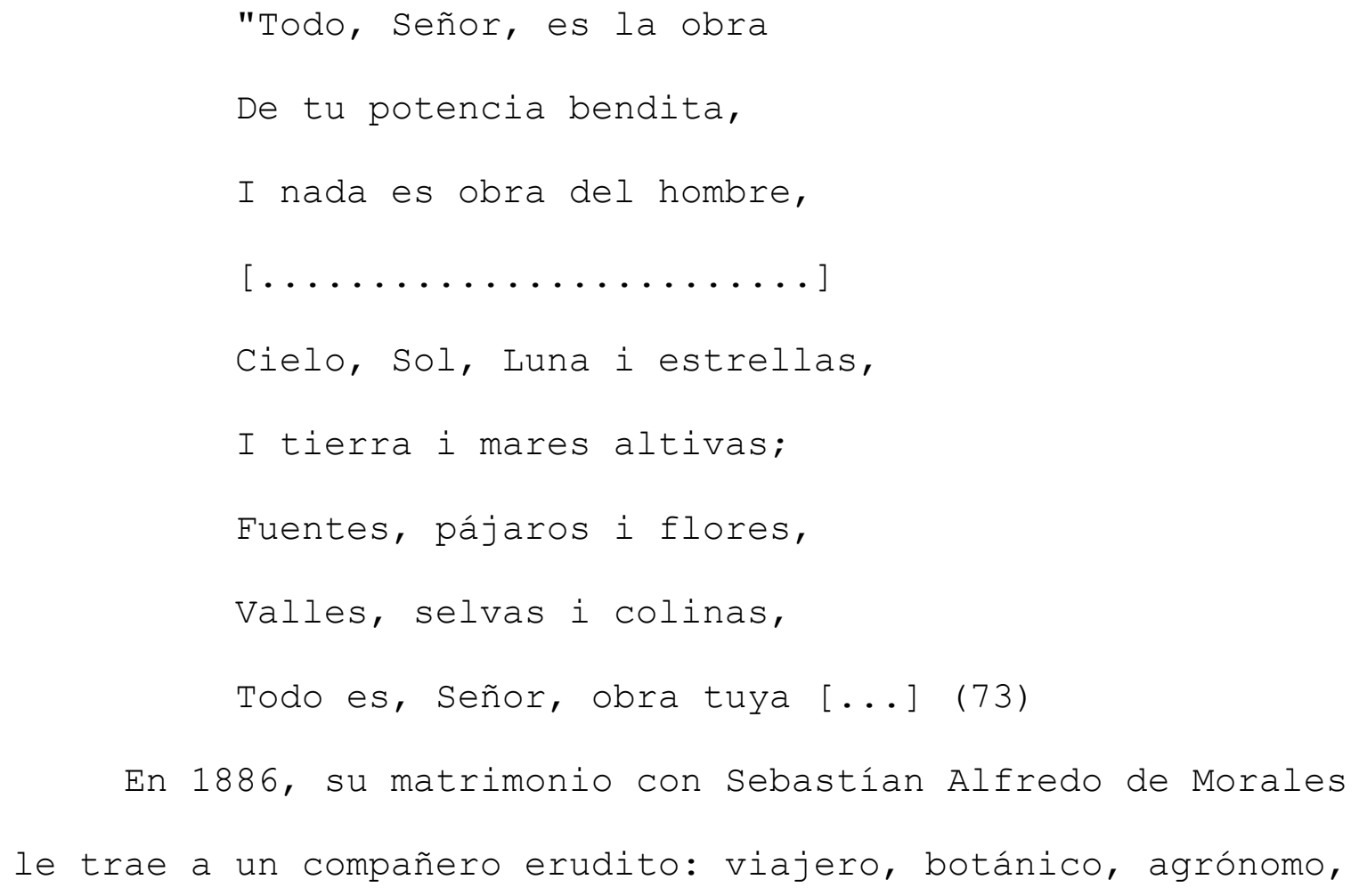


autor de estudios de minerología y médico homeópata que dictó cátedras de Historia Natural y de Agricultura en el Instituto de Segunda Enseñanza de Matanzas, donde además ejerció el periodismo y se dedicó a la poesía, pero no publicó ningún libro. Max Henríquz Ureña, al referirse a esta unión afirma que de Morales: "[c]asó con una poetisa mediocre, aunque superior a él" (182). Posteriormente Sebastián A. de Morales sufrió persecusión política por lo que la escritora tuvo que residir largo tiempo fuera de Cuba (Rocasolano, 123), y a pesar de que en el Diccionario de la literatura cubana no se aclara por qué "[e]n 1876 [...] marchó a Europa de viaje" (915), es de suponer que fue acompañando al esposo.

En la poesía que nos ha llegado se nota su dominio de la métrica, así como un exquisito uso del idioma. En "Delirio," texto que tampoco aparece en su primer poemario, resaltan algunos versos que recuerdan al modernismo. En su cuarta estrofa introduce el tema que da título al texto, y donde también está presente, indirectamente, la conciencia de ser mujer en su época:

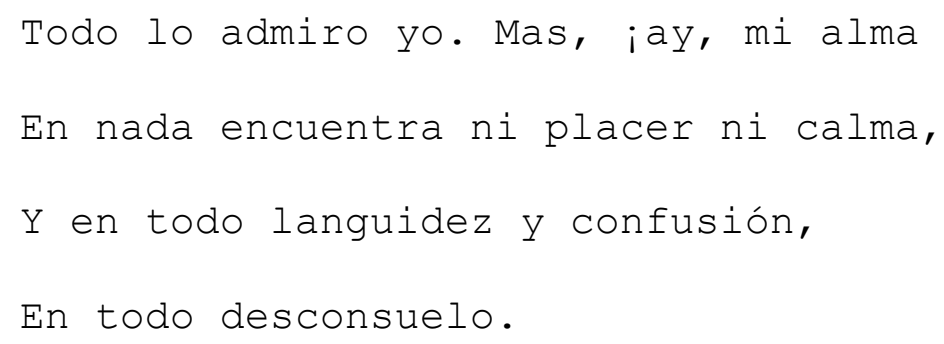


Y le mata, iay, Dios!, este punzante anhelo,

Y este ardiente afanar del corazón. (Rocasolano 124)

No es, sin embargo, el sufrimiento que veíamos en Sofía Estévez, sino el deseo de encontrar un lugar más elevado al que la sociedad de su tiempo la condenaba. Ese deseo se ve reflejado en la quinta estrofa:

De mi alma se levanta eternamente

Un eco, que agobiándome inclemente,

Incesante me grita: «iMás allá!»

Y en mi delirio ciego,

¡Ay!, camino, camino y nunca llego

A la dulce y dorada realidad. (Rocasolano 125)

En los tres primeros versos de la octava estrofa vemos una proyección del futuro modernismo: "Seis puertas de magnífico topacio/Van girando despacio, muy despacio,/Sobre goznes de perlas y rubí..." (Rocasolano 125). Son, no obstante, las estrofas doce y trece las que poseen el intrígulis del poema, donde yace, según la autora, la causa que no le permite elevarse como las aves de su paisaje poético ni cantar libre como el experimentado sinsonte de su lírico bosque de vocablos:
¡Oh!, mundo de armonías, do mi alma
Pudiera hallar a su martirio calma 
Sacudiendo la carga del dolor,

Yo quiero sublimarme,

Y de tus puras flores coronarme

Empapada en la savia de tu amor.

\section{Yo quiero disfrutar de tus placeres.}

En este que habitamos, las mujeres,

Víctimas resignadas siempre son

De la calumnia impía,

Que agitando su cólera sombría

Les llena de amargura el corazón. (Rocasolano 126)

(Énfasis nuestro)

Es esa desigualdad la que la hace sufrir y cuestionarse. La poeta, la intelectual sensible, ve la belleza del mundo pero sabe que no puede disfrutarla a plenitud como el hombre. La estrofa dieciséis muestra que ella no se amilana:

«iAdelante, adelante!» en tono seco

Repite a mi alma atormentada, el eco, «La tierra no se ha hecho para ti.»

«iAdelante, adelante!...»

Y yo sigo mi senda vacilante,

Devorando mis penas, jay de mí! (Rocasolano 127) 
Siente, como mujer, con voz de adelantada. Voz que es clamor universal de los males humanos; que nos enseña cuán consciente estaba de su labor intelectual.

"A Camila Sobrado," largo texto compuesto por diecinueve octavas, está dedicado a otra mujer, quien "quiere [...] dirigir el débil paso/Por la senda gloriosa del Parnaso/En alas de la escelsa poesía." (N. pág.). Lleno de advertencias para la aparente principiante, le dice, por ejemplo, que no lea "pueriles novelas amorosas" (N. pág.). Sin embargo le aconseja el "Parnaso español" (17) y otros versos como los siguientes:

También pueden guiar tu débil paso

Al alto fin que señalarte quiero,

Los poemas gravísimos de Homero

I los cantos magníficos del Tasso;

Las églogas del tierno Garcilaso

Del canto pastoril son el sendero,

I te darán su poderoso auxilio

Las bucólicas bellas de Virgilio. (17)

Catalina Rodríguez, desde el poema, manda a su amiga además de a estudiar, a fijarse en la naturaleza, y en los seres que la habitan y hace hincapié en las mujeres: que cante, dice. "[...] a la joven madre cariñosa/Que se consagra 
con afan constante/a los tiernos cuidados de su infante [...] (17-18); o a la "guajira/Que por amores sueña, i por amor suspira" (18). Proyecta en estos consejos los criterios que posee sobre las creadores y huye de la "debilidad" que se achacaba a la mujer en su época:

Los jemidos del negro desencanto

No sientan bien al femenil decoro,

I es del poeta la misión sublime

Secar el llanto del que triste gime (19).

Otra sextina, "Sátira a Elisa," muestra que estaba muy consciente de la frivolidad que representa el poner demasiado énfasis en la apariencia, para ser objeto de veneración masculina. Catalina lo versifica con una gran ironía:

¿Los lucientes cabellos, qué se vuelven?...

El carmín de la tez, los lindos ojos,

En el polvo y la nada se resuelven.

No templan de la parca los enojos

Los dientes de marfil, la tersa frente,

El cuello de azahar, los labios rojos. (Rocasolano $128)$

En 1893, un año antes de morir, Manuela Herrera de Herrera le antologa una composición de 96 versos "Un año más," donde hay una carga de tristeza que se manifiesta por la 
lejanía del destierro. El poema destaca, además, la profundidad moral de la escritora. Los primeros versos expresan el dolor de un tiempo más fuera de su suelo:

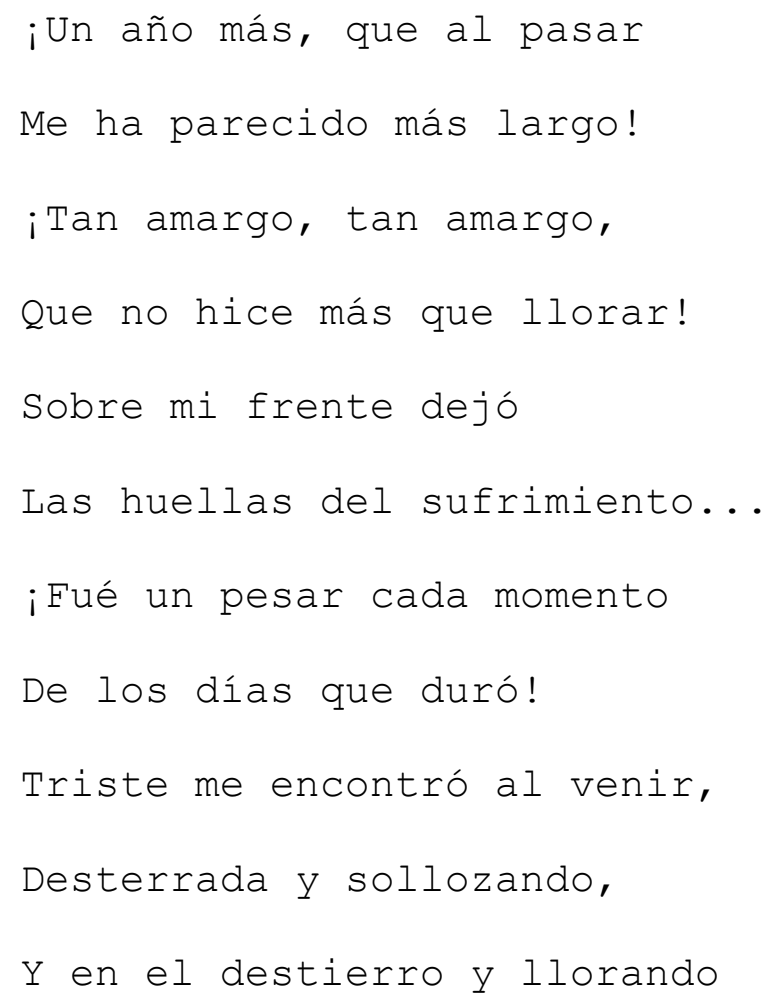




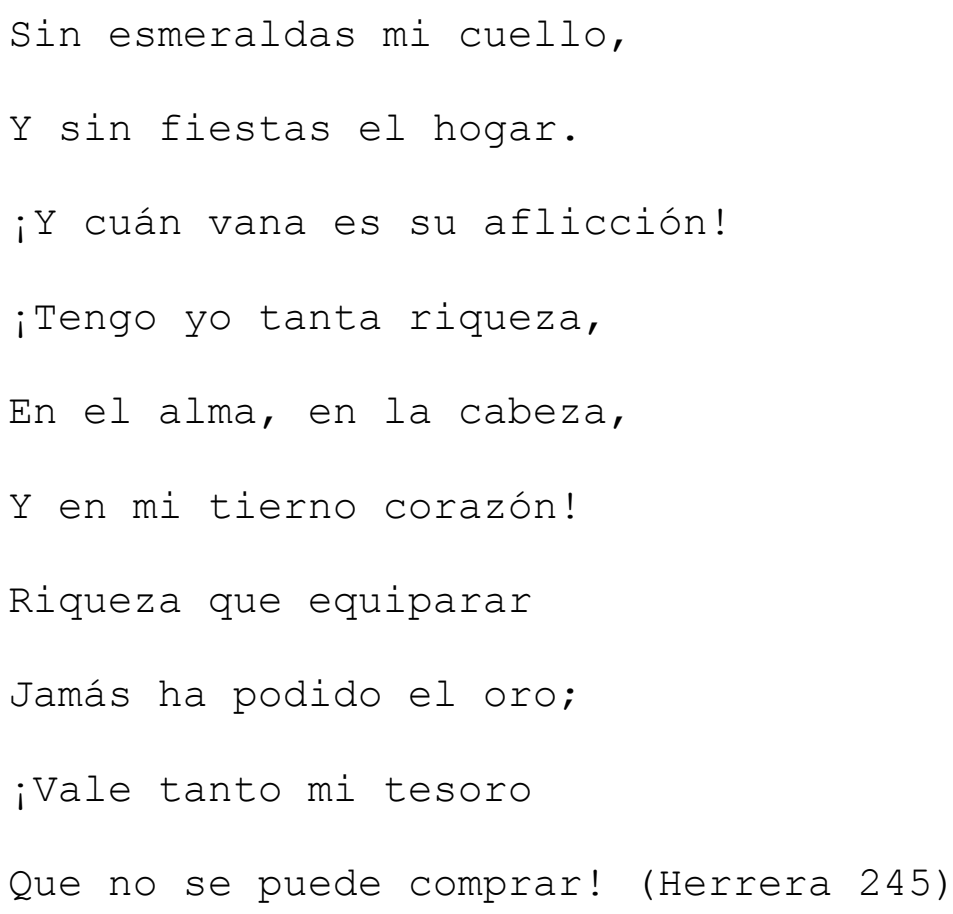
composición:

$$
\begin{aligned}
& \text { Voy viviendo sin sentir } \\
& \text { Ni rencor ni odio culpable, }
\end{aligned}
$$


Ni la ambición detestable

Que no me deje vivir.

Y si hoy, del arpa al compás,

Tantas quejas he vertido,

Es solo porque he vivido

Sin la patria un año más. (Herrera 246)

5 b. Cuento

Los relatos que conocemos de Catalina Rodríguez son los aparecidos en su Libro de las niñas, de 1892, cuando la autora tenía 57 años y que según se expresa en la portada es una "[l]ectura amena adaptada á las niñas que asisten á los Colegios de $1^{a}$ enseñanza, escrita expresamente para este objeto [...]." Tiene un prefacio de "El editor," que leyó el manuscrito, quien afirma que "lo juzg[ó] adecuado al objeto que se dedica" (N. pág.). Lo que demuestra la existencia de un censor. Además de las narraciones, el tomo cuenta con algunos poemas. En ellos la ortografía ha cambiado con respecto a Poesías de 1886. Por ejemplo, en "El amo y la esclava," igual composición de aquél que se repite aquí, ya aparece el uso de la y griega. Podría ser debido a que el nuevo libro, de 1892, estaba dedicado a la educación escolar. Las narraciones que contiene son diez, todas dirigidas a la formación de la mujer desde su infancia. 
"Consejos de una madre," trata de una niña que ha recibido una penitencia en la escuela, de parte de la directora, por cruzar las piernas, y se lo cuenta a su progenitora. Catalina Rodríguez aprovecha el breve acontecimiento para advertir que: "la niña que cruza las piernas en presencia de las gentes, parece impúdica" (6). Se vale de la conversación, además, para criticar a la sociedad de su época y el trato hacia las mujeres que ejercían la labor de educadoras: "[n]o tienen poca desgracia las señoritas y señoras que en Cuba se dedican al magisterio, que tan mal retribuído está, porque generalmente el último dinero que se paga entre nosotros es el que pertenece al que enseña" (7) . "Isabelita" es la historia de una niña que sale a pasear al campo llevando en su bolsillo "un tratado de moral que con frecuencia estudiaba, porque sus deseos más vivos eran los de ser una niña bien educada" (N. pág.). Entre los consejos que lee, están respetar a los ancianos, al que se dedica el resto del cuento.

"Luisa y su mamá," habla de Manuelita, una niña muy bella que "no es amada de la generalidad como lo son las otra[s]" (N. pág.). La madre le aclara a Luisa que esto se debe a que "sus padres y sus maestros no han sabido imprimirle [...] la belleza del alma, que es la más importante. Manuelita está mal 
educada, es despótica, se burla de los infelices y despide con tono airado a los tristes mendigos que le piden una limosna" (N. pág.). Al final Luisa y el resto de sus compañeras abandonan a Manuelita debido a sus modales.

"Malas costumbres," trata de inculcar los buenos modales: no preguntarle la edad a las personas, no hacer visitas sin avisarlas, no llegar a las casas a las horas de las comidas, etc.

"El trabajo," muestra cuán noble es trabajar. Llama la atención un párrafo que, como en todos estos relatos se refire a la mujer y exclama: "i[c]uán interesante y respetable se hace la que á fuerza de laboriosidad y constancia se apodera de los conocimientos de la botánica, de la física, de la astronomía ó de calquier otro ramo del saber humano!" (35).

"Las abejas" es una lección de zoología y sus aplicaciones en la industria. Una alegoría de fondo como todos los anteriores, que brinda, en forma de cuento conversado, un anciano a su nieta.

"Costumbres de algunos animales," es una continuación de los mismos personajes anteriores. Esta vez la niña, al día siguiente, pregunta "sobre las costumbres de las palomas caseras" (N. pág.), y el abuelo se extiende hablando de la fidelidad entre las palomas, de cómo tanto el macho como la 
hembra cuidan el nido, y de la vida amorosa de las mismas hasta el fin de sus días. Varios párrafos posteriores están dedicados a otros animales: gallos y gallinas, caballos, perros, pavos reales y caimanes.

"Clarita y su institutriz," continúa el tono de los anteriores. En este caso una niña habla con su institutriz sobre otra, fea y pobre, que todos aman porque es muy buena y posee una educación excelente. "Sé prudente y moderada en tus palabras y en tus ademanes," le dice la adulta, "que la prudencia y los modales suaves realzan mucho á la mujer" (59), (énfasis nuestro). Y estas palabras, dichas desde el relato, muestran lo que era bien visto en la mujer de su tiempo.

"Doña Dolores y su hija" trata sobre los modales que se deben de tener en la mesa, con modos que hoy provocan la risa. "[D] ebemos respetar la tranquilidad de nuestros compañeros de mesa, porque una incomodidad de espíritu á la hora de comer, puede provocar una congestión fulminante al cerebro, que mata á una persona con la misma rapidéz que la mataría un rayo." (62)

En "El bombix," un padre explica a su hija la historia de la seda y su producción. Aprovecha para criticar la indolencia y la falta de iniciativas en la Cuba de entonces. 
Estos relatos de Catalina Rodríguez no se pueden considerar como aciertos pero cumplen una función didáctica, que es su objetivo principal. Su poesía, indiscutiblemente, es mucho más valiosa que su narrativa. 
Conclusiones

La liberación de la mujer en la literatura ha tenido un desarrollo lento. Durante el siglo que nos ocupa, ocurrió en Cuba un período de "Renacimiento" en cuanto a la creación femenina se refiere. No se puede olvidar lo difícil que les fue a estas autoras, a lo largo de todo el siglo XIX, abrirse paso en un mundo dominado por el hombre. La sociedad de entonces miraba al ente femenino como un objeto del deseo masculino que no podía exponer opinión alguna y menos aún proyectar su erotismo. La mujer era considerada el ángel del hogar y se le preparaba para atender al esposo y a la familia. Las escritoras tuvieron que luchar contra este esteriotipo. Fueron ellas las primeras que lo hicieron en grupo, pues anteriormente las manifestaciones habían sido aisladas, como es el caso de Sor Juana Inés de la Cruz y su Respuesta a Sor Filotea (1693), considerada como un primer manifiesto feminista, o el de Juana Pastor y sus olvidados versos.

Tomando a las primeras románticas cubanas, Gertrudis Gómez de Avellaneda, Mercedes Valdés Mendoza y Luisa Molina, todas nacidas entre 1814 y 1821, vemos como la Avellaneda, después de la queja que diera en solitario Juana Pastor, es quien produce la protesta más abarcadora. Ella, como ninguna escritora de su tiempo, se expresa con las normas masculinas y 
reafirma su erotismo. La Avellaneda desempeñó un papel de avanzada determinado por la notoriedad que alcanzara tanto en la isla como en la metrópoli. Su obra se leyó y sus formas poéticas fueron imitadas. De los géneros tenidos en cuenta en nuestro estudio, es en los relatos donde muestra sus ideas feministas de una manera más vigorosa. Fue la primera mujer a quien se le negó el ingreso a la Real Academia Española, lo que muestra la importancia que alcanzara dentro de las letras hispánicas. Mercedes Valdés Mendoza sobresale tanto por la conversión de su voz en masculina como, sútilmente, por la expresión del tema erótico aunque también por la búsqueda de la gloria. Luisa Molina, inmersa en una situación de pobreza, no tuvo ojos para mirar las injusticias a que eran sometidas sus compañeras.

En las voces del "Segundo Romanticismo," nacidas hacia la tercera década del siglo XIX, existen las quejas directas de Luisa Pérez de Zambrana y de Adelaida del Mármol. Úrsula Céspedes evita manifestarse directamente y toma el cuerpo masculino para proyectar una fuerza sólo concebida entonces en el varón pero, aunque fuera entre los esclavos, manifiesta ideas de igualdad entre el hombre y la mujer; así como conciencia de una sexualidad femenina que negaba su tiempo. Luisa Pérez de Zambrana al inicio de su carrera alzó su voz 
poderosamente para luego silenciarla. No obstante, supo decir desde su autorretrato que prefería ser vista como una estudiosa a aparecer como objeto del deseo masculino y afirmó que la mujer era una esclava, lo cual consideraba como una "costumbre [...] fatal" de su época. Brígida Agüero no muestra nada más allá de su deseo de fama, sólo permitida al hombre, pero no hace acusación directa en contra del machismo imperante, lo cual tampoco aparece en Julia Pérez Montes de Oca, inmersa en sus padecimientos morales y físicos, ni en María de Santa Cruz, ocupada en una poética de la familia, la naturaleza, los amigos, la melancolía y la brevedad de la vida. Es Adelaida del Mármol, la más joven de todas las creadoras mencionadas en este trabajo, quien proyecta un juicio ético feminista en su poema "Razones de una poetisa," agudo examen de la sociedad decimonónica cubana, e indiscutiblemente una creación que está dirigida al hombre y a su pensamiento patriarcal. Adelaida del Mármol había recibido la influencia indudable de Sor Juana Inés de la Cruz. Las creadoras que forman parte de la "Declinación del Romanticismo," si bien en su generalidad nacen en las cercanías de los mediados del siglo, no van más allá que las anteriores. Aunque es notorio que la mayoría, además de la poesía sentimental entonces concebible como obra propiamente 
femenina, se ocupa del cuento. Martina Pierra persigue la gloria, quiere sobresalir, no sólo por encima de mujeres tan célebres como Safo, sino incluso de poetas como Homero, pero aún al expresarse tiene necesidad de convertir su voz en masculina para proyectar hechos sólo autorizados en el varón. Aurelia Castillo es la figura más prominente del período en lo que a manifestación de un pensamiento que buscaba la igualdad entre ambos sexos se refiere. Por desconocimiento, hasta hoy ha sido ignorado que fue ella la creadora del minicuento en América Latina en 1912 y no el mexicano Julio Torri, a quien se le ha señalado la paternidad del género en 1917, con la publicación de Ensayos y poemas, cinco años después que ella. Rosa Kruger, por su lado, esboza de una forma alegórica la sumisión de la mujer a su sociedad. Sofía Estévez va también tras la gloria y se considera superior a los autores al comparárseles mientras tiene plena conciencia de que es mujer y, por ende, "no puede nada." Catalina Rodríguez se queja de la desigualdad y huye de ser un objeto del deseo del hombre. Las creadoras cubanas románticas pueden considerarse dentro de las primeras dos fases descritas por Elaine Showalter: la de imitación e internalización de las normas masculinas 0 fase «femenina» y la fase de la protesta $(\ll f e m i n i s t a »)$. 
Fue el romanticismo el momento en que ocurrió la llamada hipertrofia del yo, esa subjetividad intensa que destacó el ser y lo convirtió en centro y eje de su creación. En el período, la rebeldía de las creadoras se juntó y tuvieron conciencia de pertenencer a un colectivo, comenzando a apoyarse y solidarizarse con sus semejantes -las mujeres. La visión que se vertió sobre los marginados benefició el surgir de sus voces y el irse abriendo camino, desde sus hogares, en el mundo machista y patriarcal que las había silenciado. Si bien no se logró la máxima libertad creadora, las románticas en su mayoría se hicieron dueñas de su destino y retomaron con más fuerza la idea de la emancipación femenina que había sido expuesta ya, pero sólo por voces aisladas en la historia de la literatura. Lo nuevo en el período fue que las mujeres se agruparon y desde sus creaciones formaron una totalidad que expandió sus fronteras y las sacó de las prisiones ideológicas que hasta ese momento constituían su familia y sus sociedades.

El fenómeno del romanticismo cubano resulta interesante pues no sólo se manifiesta en la obra escrita sino en el hecho de que las autoras empezaron a participar en tertulias literarias, a tomar las riendas de los periódicos, como el fundado por Sofía Estévez en 1866 en Camagüey, junto con Domitila García. En otros casos, se crearon revistas 
literarias como la dirigida por Gertrudis Gómez de Avellaneda, donde se publicaron artículos sobre la mujer, por ellas y para ellas mismas. Hubo también un auge de antologías dedicadas a las creaciones femeninas preparadas por las propias mujeres como la de Domitila García de Coronado o la de Manuela Herrera de Herrera, condesa de Mortera, editada para la Exposición Universal de Chicago.

Sin embargo, el hecho que se vio en Cuba no fue aislado sino universal. Ocurrió durante los mismos años en Europa y en los Estados Unidos, porque el romanticismo recorrió todas las geografías y se extendió por el mundo al decir de Octavio Paz, "como si fuera una epidemia espiritual" (92). Sería bueno ver los hechos de manera concatenada: uno impulsó al otro, y el impulso inicial hizo que finalmente las barreras comenzaran a caer.

Las luchas de la mujer en la literatura continúan. Grandes pasos se han dado desde el romanticismo. No obstante, a pesar de lo avanzado, aún el predominio sigue estando en manos del hombre. La trayectoria del debate femenino, que comenzó en el siglo XIX, muestra que la mujer ha permanecido en la contienda hasta hoy para liberarse de tal predominio. Esta controversia, empezada entonces, sitúa a las creadoras románticas en el contexto de nuestra contemporaneidad. 
Obras citadas

Álzaga, Florinda. La Avellaneda: intensidad y vanguardia. Miami: Universal, 1997.

Azcárate, Nicolás. Noches literarias en casa de Nicolás Azcárate. 2 vols. La Habana: Imprenta La Antilla, 1866.

Ballagas, Emilio. "Mariposa insular." Homenaje a Gertrudis Gómez de Avellaneda. Memorias del simposio en el centenario de su muerte. Miami: Universal, 1981. 145-152.

Baquero, Gastón. "Gertrudis Gómez de Avellaneda como prosista." Gertrudis Gómez de Avellaneda. Madrid: Fundación Universitaria Española, 1974.

Bravo-Villasante, Carmen."La Avellaneda: una mujer en sus cartas y en su poesía." Gertrudis Gómez de Avellaneda. Madrid: Fundación Universitaria Española, 1974.

Bueno, Salvador. "Introducción." Viaje a La Habana. La Habana: Arte y Literatura, 1974. 7-60.

Byron, George Gordon, lord. "JEPHTHA'S DAUGHTER." The Complete Poetical Works of Byron. Cambridge: The Riverside Press, 1933. 218

Cabrera Araújo, David. Adelaida del Mármol, primera poetisa holguinera. Holguín: Colección de la Ciudad, 1991.

Calcagno, Francisco. Diccionario Biográfico Cubano. New York: Imprenta y Librería de N. Ponce de León, 1878.

Carilla, Emilio. El romanticismo en la América Hispánica. Vols 1 y 2. Madrid: Gredos, 1975. 2 vols.

Casal, Julian del. Bustos y rimas. Habana: Imprenta La Moderna, 1893. Miami: Editorial Cubana, 1993.

Castellanos, Jorge e Isabel Castellanos. Cultura afrocubana. 4 vols. Miami: Universal, 1992.

Castillo de González, Aurelia. Fábulas. 2nd ed. Habana: Imprenta y papelería de Rambla y Bouza, 1910. 
--- Escritos de Aurelia Castillo de González. 6 vols. Habana: Imprenta «El siglo XX», 1913

Céspedes de Escanaverino, Úrsula. Poesías/Selección y prólogo Juan J. Remos. La Habana: Ministerio de Cultura, 1948.

Cortina, José Antonio. "Prólogo." Obras de Rosa Kruger precedidas de un prólogo por José Antonio Cortina. Tomo Primero. Habana: Establecimiento tipográfico de la viuda de Soler, 1883. III-VIII.

Cruz, Juana Inés de la. "Arguye de inconsecuentes el gusto y la censura de los hombres que en las mujeres acusan lo que causan." Renaissance and Baroque Poetry of Spain. Ed. Elias L. Rivers. Illinois: Waveland Press, Inc., 1996. $(322-324)$

Cruz, Mary. "Prólogo." Tradiciones. La Habana: Letras Cubanas. $1987.7-28$.

Chaple, Sergio. "Prólogo." Antología poética. Luisa Pérez de Zambrana. La Habana: Letras Cubanas, 1977. 13-31.

Delmonte G., J. "SOFIA ESTEVEZ VALDÉS." Lágrimas y sonrisas. Colección de poesías originales de la señorita $D^{a}$. SOFIA ESTEVEZ VALDÉS. Habana: Imprenta de la Viuda de Barcina y Compañía, 1875. VII-X.

Diccionario de la lengua española. Real Academia Española. Vigésima primera edición. Madrid: Espasa Calpe, 1992. 2 Vols.

Diccionario de la literatura cubana. 2 vols. La Habana: Letras Cubanas, 1980-84.

Esbozo de una nueva gramática de la lengua española. Real Academia Española (Comisión de gramática). Decimoséptima edición. Madrid: Espasa Calpe, 1998.

Escarpanter, José A. "El teatro de la Avellaneda." Gertrudis Gómez de Avellaneda. Madrid: Fundación Universitaria Española, 1974 . 
Estévez y Valdés, Sofía. Lágrimas y sonrisas. Colección de poesías originales de la señorita $\mathrm{D}^{a}$. SOFIA ESTEVEZ VALDÉS. Habana: Imprenta de la Viuda de Barcina y Compañía, 1875 .

---. "Al Sr. Doctor D. M. R. S." Lágrimas y sonrisas. Colección de poesías originales de la señorita $D^{a}$. SOFIA ESTEVEZ VALDÉS. Habana: Imprenta de la Viuda de Barcina y Compañía, 1875. V-VI.

Feijóo, Samuel. La décima culta en Cuba. Las Villas: Universidad Central, 1963.

---. El movimiento de los romances cubanos del siglo XIX. La Habana: Consejo Nacional de Universidades, 1964.

--- Cantos a la naturaleza cubana del siglo XIX. Las Villas: Consejo Nacional de Universidades, 1964. 225.

Flores, Ángel, Kate Flores. Poesía feminista del mundo hispánico (desde la edad media hasta la actualidad). México: Siglo XXI, 1988.

Florit, Eugenio. "Algunas anticipaciones de la Avellaneda." Poesía, casi siempre (Ensayos literarios). Madrid: Mensaje, 1978. 53-61.

García Castañeda, José A. La municipalidad holguinera/su creación y su desenvolvimiento hasta 1799. Manzanillo: "El Arte," 1949.

García Copley, Federico. "Prólogo a la edición de 1856." Antología poética. Luisa Pérez de Zambrana. La Habana: Letras Cubanas, 1977. 115-122.

García de Coronado, Domitila. Album Poético Fotográfico de Escritoras y Poetisas Cubanas. Habana: Imprenta "El Fígaro," 1926.

Gatell, Angelina. "La poesía femenina en el romanticismo cubano."Cuadernos Hispanoamericanos. Madrid: Sep. 1963. No. 165 541-544.

Gómez de Avellaneda, Gertrudis. Biblioteca de autores españoles. Ed. José María Castro y Calvo. Vol 272. Madrid: Atlas, 1974. 
---.Biblioteca de autores españoles. Ed. José María Castro y Calvo. Vol 288. Madrid: Atlas, 1974. --- $\frac{\text { Poesías y epistolario de amor y de amistad. Madrid: }}{\text { Castalia, 1989. }}$

--- "Luisa Molina." La Avellaneda: intensidad y vanguardia. Miami: Universal, 1997.

---. Tradiciones. La Habana: Letras Cubanas. 1987.

--- Carta al Exmo Sr. Marqués de Alcañices. 22 de abril de 18.. Cuban Heritage Collection. Otto G. Richter Library. University of Miami., Miami. Carta inédita.

---. "Prólogo a la edición de 1860." Antología poética. Luisa Pérez de Zambrana. La Habana: Letras Cubanas, 1977. 122-129.

González Curquejo, Antonio. Florilegio de escritoras cubanas. 3 vols. Habana: Lib. é Imp. "La Moderna Poesía," 1910-1919.

González Herrero, Lourdes. "Una poetisa holguinera." Acercamiento a la poesía femenina de habla hispana. Holguín: Colección de la Ciudad, 1992. 42-46.

Gutiérrez-Vega, Zenaida. "La poesía de madurez de Luisa Pérez de Zambrana." Boletín de la Biblioteca de Menéndez Pelayo. Vol. 62. 1986. 187-198.

Harter, Hugh A. Gertrudis Gómez de Avellaneda. Boston: Twayne, 1981 .

Henríquez Ureña, Max. Panorama histórico de la literatura cubana. Vols 1 and 2. México: Mirador, 1963

Hernández de Norman, Isabel. La Novela Criolla en las Antillas. Madrid: Plus Ultra, 1977

Hernández-Miyares, Julio E. "Variaciones en un tema indianista de la Avellaneda: el epílogo de Guatimozín y una anédota de la vida de Cortés." Homenaje a Gertrudis Gómez de Avellaneda. Memorias del simposio en el centenario de su muerte. Miami: Universal, 1981. 318-328. 
Hernández Pavón, Zenovio. Carta al autor. 1 ro de Agosto de 2000. Carta inédita.

Herrera de Herrera, Manuela. Escritoras cubanas. Composiciones escogidas de las más notables autoras de la Isla de Cuba. Obra editada bajo los auspicios de la Excma. Señora Da. Manuela Herrera de Herrera, Condesa de Mortera, para ser presentada en la Exposición Universal de Chicago, conmemorativa del IV Centenario del Descubrimiento de América. Habana: "La Universal," 1893.

Jiménez, Luis A. "Adelaida del Mármol, rescatando a la poeta creadora del jardín cubano en el siglo XIX. "Círculo: Revista de Cultura. Vol. XXVIII. 1999. 155-162.

Jorrín, José S. "Improvisación." Noches literarias en casa de Nicolás Azcárate. 2 vols. La Habana: Imprenta La Antillas, 1866. 319-331.

Kirkpatrick, Susan Las Románticas. Escritoras y subjetividad en España, 1835-1850. Trans. Amaia Bárcena. Madrid: Cátedra, S.A., 1991.

Kruger, Rosa. Obras de Rosa Kruger-precedidas de un prólogo por José Antonio Cortina. Tomo Primero. Habana: Establecimiento tipográfico de la viuda de Soler, 1883.

Kutzinski, Vera M. Feminst Theory and Criticism." The Johns Hopkins guide to literary theory and criticism. Baltimore: The Johns Hopkins Universiy Press, 1994. 138142 .

Lazo, Raimundo. El romanticismo. México: Porrúa, S. A., 1992.

León, René. Luisa Pérez de Zambrana: bibliografía (1835-1918). North Carolina, 1992.

Lichtblau, Myron I. "La leyenda de la velada del helecho: análisis de la técnica narrativa." Homenaje a Gertrudis Gómez de Avellaneda. Memorias del simposio en el centenario de su muerte. Miami: Universal, 1981. 329-337.

Lezama Lima, José. Antología de la poesía cubana. 3 vols. La Habana: Consejo Nacional de Cultura, 1965.

López Prieto, Antonio. Parnaso Cubano. Habana, 1881. 
Márquez Sterling, Carlos. José Martí-Síntesis de una vida extraordinaria. México; Porrúa, 1982.

Martí, José112. "Tres libros. Poetisas americanas." Antología poética. Luisa Pérez de Zambrana. La Habana: Letras Cubanas, 1977. 134-138.

Montoya de Zayas, Ondina. "La Avellaneda en su tiempo." Homenaje a Gertrudis Gómez de Avellaneda. Memorias del simposio en el centenario de su muerte. Miami: Universal, 1981. 111-131.

Nápoles Fajardo, Juan Cristobal. "A Adelaida del Mármol para su corona fúnebre." El Redactor. Santiago de Cuba: domingo 12 de septiembre de 1858. Año 26. Número 12.

Paz, Octavio. Los hijos del limo. Barcelona: Seix Barral, 1993.

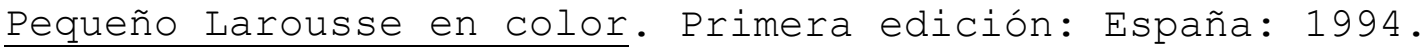

Pérez Montes de Oca, Julia. Poesías completas. La Habana: Imp. P. Fernández y Cía., S en C, 1957.

Pérez de Zambrana, Luisa. Antología poética. La Habana: Letras Cubanas, 1977 .

---. "¡Está muerta! Poesías de Luisa Péres de Zambrana (publicadas e inéditas.) Habana: Imprenta "El Siglo XX," $1920.46-47$.

Remos y Rubio, Juan J. Historia de la literatura cubana. 3 vols. Miami: Mnemosyne Publishing Co., 1969

--- Proceso histórico de las letras cubanas. Madrid: Ediciones Guadarrama, 1958.

--- "Úrsula Céspedes de Escanaverino." Poesías. La Habana: Ministerio de Cultura, 1948.

Rexach, Rosario. Estudios sobre Gertrudis Gómez de Avellaneda (La reina mora de Camagüey). Madrid: Verbum, 1996.

Ripoll, Carlos. Naturaleza y alma de Cuba/Dos siglos de poesía cubana/1760-1960. Madrid: Anaya, 1974. 
Riva Abreu, Valentín. Parnaso cubano. Selectas composiciones poéticas. Barcelona: Casa Editorial Maucci, 1926.

Rocasolano, Alberto. Poetisas Cubanas. La Habana: Letras Cubanas, 1985 .

Rodríguez, Catalina. Poesías. Matanzas: Imprenta Aurora del Yumurí, 1866.

---. Libro de las niñas. Habana: Editor: Elías Fernández Casona, 1892 .

Rodríguez de Cuesta, Vicentina Elsa. Patriotas cubanas. Pinar del Río: Talleres "Heraldo Pinareño," 1952. 121-122

Romeu, Raquel. La mujer y el esclavo en la Cuba de 1840 . Uruguay: Asociación de literatura femenina hispánica, 1987 .

Rueda Hernanz, Germán. La desamortización en España: un balance (1766-1924). Madrid: Arco/Libros, S.L., 1997.

Ruiz-Gaytán de San Vicente, Beatriz. "Gertrudis Gómez de Avellaneda y el pensamiento hispanoamericano de su tiempo." Homenaje a Gertrudis Gómez de Avellaneda. Memorias del simposio en el centenario de su muerte. Miami: Universal, 1981. 52-68.

Sabat de Rivers, Georgina. "Sor Juana Inés de la cruz y Gertrudis Gómez de Avellaneda: dos voces americanas en defensa de la mujer." Homenaje a Gertrudis Gómez de Avellaneda. Memorias del simposio en el centenario de su muerte. Miami: Universal, 1981. 99-110.

Saínz Blanco, Alfredo. "Adelaida de la Ciudad." Mi más querido fantasma. Holguín: Colección de la Ciudad, 1993. 87-89.

Salgado, María A. "El arte de la leyenda en Gertrudis Gómez de Avellaneda." Homenaje a Gertrudis Gómez de Avellaneda. Memorias del simposio en el centenario de su muerte. Miami: Universal, 1981. 338-346.

---. "Desenmascarando el cuadro: El autorretrato de Luisa Pérez de Zambrana." Letras femeninas. Vol. XXII. No. 1-2. 1996. 211-24. 
Santa Cruz, María de. Historias campesinas. Habana: Imprenta y Librería de M. Ricoy, 1908.

Schulman, Ivan A. Símbolo y color en la obra de José Martí. Madrid: Gredos, 1970 .

Soler Mirabent, Antonia. "Úrsula Céspedes de Escanaverino." Cuatro poetas. La Habana: Academia, 1990. 23-33.

Suárez-Murias, Marguerite C. La novela romántica en Hispanoamérica. Salamanca: Hispanic Institute in the United States, 1963.

Traducción del Nuevo Mundo de las Santas Escrituras. New York: Watchtower Bible and Tract Society, 1987.

Trelles, Carlos M. Bibliografía Cubana del Siglo XIX. 8 vols. Matanzas: Imp. Quirós y Estrada, 1911-15. Germany: Kraus Reprint LTD., 1965.

Triviño Anzola, Consuelo. "Microantología del minicuento americano." Cambio 16. 1 de marzo de 1993. No 1.110. $24-31$.

Varona, Enrique José. "Al lector." Poesía de Luisa Pérez de Zambrana-(Publicadas e inéditas). Habana: Imprenta "El Siglo XX," 1920. 5-10.

Vitier, Cintio. Los grandes románticos cubanos. Antología. la Habana, Lex, 1960.

---. Lo cubano en la poesía. La Habana: Letras cubanas, 1970.

Yañez, Mirta. "El discurso femenino finisecular en Cuba: Aurelia del Castillo y otras voces en torno al 98." Con el lente oblicuo. La Habana: Instituto de Literatura y Lingüistica, 1999. 17-37.

Zatlin Boring, Phyllis. "Una perspectiva feminista sobre «La Confesión» de Avellaneda." Homenaje a Gertrudis Gómez de Avellaneda. Memorias del simposio en el centenario de su muerte. Miami: Universal, 1981. 93-98 
1. Ésta es una obra que consta de tres volúmenes, según la bibligrafía del libro citado de Max Henríquez Ureña.

2. Las fechas específicas entre las cuales ocurrió esta toma se sitúan entre agosto de 1762 y julio de 1763, estando España en guerra contra Inglaterra. Durante este período las tropas británicas ocuparon La Habana. (Pequeño Larousse).

3. Raquel Romeu en La mujer y el esclavo en la cuba de 1840, hace un análisis sobre la vida de Juan Francisco Manzano donde menciona un estudio de Ildefonso Pereda Valdez y afirma que éste fue el "primer poeta importante de [la] raza negra que aparece en cuba" (cit. en Romeu 1). Manzano, agrega Romeu, "nació en La Habana [...] esclavo de una familia encumbrada" (1), "en casa de los marqueses don Juan y doña Beatriz Jústiz de Santa Ana" (7), (énfasis nuestro). Esta investigadora utiliza la autobiografía del mismo Manzano en su estudio. Pero no se menciona en parte alguna que la marquesa fuera escritora.

4. Calcagno sólo menciona el apellido. Nos imaginamos que se trate de José de Armas y Céspedes, nacido en 1834, en Puerto Príncipe, pero hasta ahora ha sido imposible verificarlo.

5. Jorge e Isabel Castellanos la señalan entre un grupo de "nombres tradicionalmente mencionados" (2: 373) y como "la primera poetisa cubana [...] [y] la distinguida profesora" (4: 134); aunque su estudio no tiene como temática la que nos atañe. Max Henríquez Ureña, en su Panorama histórico de la literatura cubana, (1: 77), también la nombra, en una nota al pie de página, aunque sólo repite las palabras de López Prieto y de Calcagno, ya expuestas en esta investigación.

6. Carilla nota una diferencia entre el indianismo y el indigenismo. Se basa en los análisis de Aída Cometta Manzoni, estudiosa del tema. El indianismo es visto así "como evocación, idealización, proyección hacia el pasado" y el indigenismo "como realidad concreta e inmediata, como realidad social" (2: 21$)$. 
7. Que aparecen en Antonio López Prieto.

8. Aparece en Poesías y epistolario de amor y amistad de Gertrudis Gómez de Avellaneda.

9. Sab, vio la luz en 1841 pero su manuscrito estaba terminado desde 1839."[S]e adelanta por toda una década a La Cabaña del tío Tom [1852] de Harriet Beecher Stowe" (Castellanos 1: 303). Gastón Baquero, al refirirse a este hecho, afirma que "la Avellaneda es una de las primeras figuras del mundo en la tarea de reivindicar al hombre negro en su dignidad y en sus derechos" (76). Kirkpatrick cree, no obstante, que esta obra se utiliza para proyectar, por medio de los personaje marginados, -en este caso el mulato esclavo Sab, y Teresa, nacida fuera del matrimoniolas ansias femeninas de reinvidicación social, y no solamente las de la situación del africano en tierras americanas (143-153).

10. En España había muerto Fernando VII. Había ocurrido una guerra civil entre liberales y carlistas y María Cristina de Borbón ocupa la regencia durante la minoría de edad de su hija Isabel. Y, según Germán Rueda Hernanz, en La desamortización en España: un balance (1766-1924), en 1834 se había iniciado la desamortización de los bienes eclesiásticos (46).

11. En su libro Gertrudis Gómez de Avellaneda.

12. En su libro Estudios sobre Gertrudis Gómez de Avellaneda (La reina mora de Camagüey).

13. Utilizamos, traducida al español, que es la lengua de nuestra investigación, las siglas "cit. en" ("citado en") por qtd in ("quoted in"), que aparecen en el MLA Handbook for Writers of Research Papers, -Fifth Edition, 1999-, en su página 220: "Citing Indirect Sources." Lo mismo haremos, desde ahora, y durante este trabajo, en casos similares.

14. Todos los poemas que se citan de Gertrudis Gómez de Avellaneda son tomados del volumen 272 de la Bibliteca de Autores Españoles.

15. Sic. 
16. Dolores Gómez Cádiz de Velazco, identificada, en 1845, como una colaboradora de La Ilustración de las Damas, que iba a dirigir Gómez de Avellaneda (Kirkpatrick 90).

17. Según el Diccionario de la lengua española de la Real Academia Española, en su vigésima primera edición (1992), éste "es uno de los pájaros más bonitos de Europa; se domestica fácilmente, canta bien."

18. En los libros donde encontramos este poema 0 donde se critica -Biblioteca de escritores españoles (277) y Las Románticas. Escritoras y subjetividad en España, 1835-1850, aparece una aclaración: "Una nota en la edición de 1850 desmiente su mediación en la inclusión del poema: 'Las instancias de sus amigos [de la autora], prendados de la novedad y armonía que atribuían al metro de este trozo, lo salvaron de la destrucción a que fue condenado el resto de la obra... (cit. en Kirkpatrick 191).

19. Texto que puede leerse en Adelaida del Mármol, de David Cabrera Araújo, páginas 78 y 79 .

20. Esperanza de Varona, directora de la Cuban Heritage Collection de la Otto G. Richter Library -University of Miami- mostró al autor de este trabajo la carta, hasta ahora inédita, original de la poeta, para ser incluida en esta investigación.

21. Sic.

22. Aquí hay una palabra ilegible, podría ser que (nota del autor de este trabajo).

23. Aparece como tradición, en una edición de Letras Cubanas, de La Habana, en 1984, pero en cuya carátula se anuncia como relato.

24. Para seguir un orden en los textos en prosa de la Avellaneda seguiremos el de sus Tradiciones, que aparece en obras citadas y que es el que sigue:

1. La Baronesa de Joux.

2. Una anécdota de la vida de Cortés.

3. La velada del helecho o el donativo del diablo.

4. Dolores. 
5. La montaña maldita.

6. La bella Toda.

7. Los doce jabalíes.

8. La dama de Amboto.

9. La ondina del lago azul.

10. La flor del ángel.

11.El aura blanca.

12. El cacique de Turmequé.

25. El Franco-Condado o Condado de Borgoña, reunido en el Sacro Imperio en 1032, formó parte de las posesiones españolas de 1496 a 1678, fecha de su unión con Francia (Pequeño Larrouse) .

26. Aunque Myron I. Lichtblau señala que "fue publicada en 1846, cuando [la] Avellaneda ya había logrado éxito como poeta y [como] novelista" (330).

27. La Avellaneda envió este cuento, al Director del Diario de la Marina, con una carta para su publicación fechada en La Habana en julio de 1860. Dicha carta puede leerse, previa a la narración, en el vol. 288 de la la Biblioteca de Autores Españoles. Allí afirma la autora: "Dolores, mi estimado amigo, existió realmente, como todos los personajes de esta historia, que parece novela, y cuyos principales hechos hallará $V$. en las crónicas de aquel tiempo" (N. pág.).

28. Estos primeros versos son de Heredia (nota de Rocasolano).

29. Según datos tomados de José Martí-Síntesis de una vida extraordinaria de Carlos Márquez Sterling.

30. Carlos M. Trelles, en el volumen sexto, página 306, de su extensa obra: Bibliografía Cubana del Siglo XIX, publicada en ocho tomos en Matanzas, entre 1911-15 y reeditada en Alemania, en 1965, la tiene como Luisa de Molina.

31. Tomo II de su Historia de la literatura cubana. 
32. Otros autores citan su nacimiento en la finca Guajabito, Bayamo, Oriente, como el Diccionario de la literatura cubana (I: 213).

33. Bayamo era por entonces una de las ciudades más cultas de la isla.

34. Según Soler, escrita en la muerte de una sobrina de don Tomás Estrada Palma (28).

35. Como El Redactor de Santiago aparece en el prólogo de Juan J. Remos a su poesía.

36. Como Semanario Cubano aparece en el prólogo de Remos a sus poemas (9), y en el Diccionario de la literatura cubana II (961).

37. De quien era deudo, como dice Carlos Ripoll, aunque no hemos encontrado qué grado alcanzaba el parentesco.

38. Manuela Herrera de Herrera señala, con relación a este tomo, que "vio la luz en su ciudad natal" (N. pág.). En este caso sería en Bayamo.

39. Prácticamente todos los textos de úrsula Céspedes de Escanaverino que analizaremos aparecen en las Poesías, prologadas por Remos. Cuando los poemas a que nos referimos no se hallan en tal libro, se menciona el lugar de dónde fueron tomados.

40. Este texto fue recopilado por Herrera de Herrera bajo el título de "Dolora." "¿Qué soy?-¿De dónde vengo?-¿Adónde voy?," aparece allí como sub-título.

41. Soler Mirabent afirma que este poema fue escrito en 1849, cuando Úrsula Céspedes de Escanaverino contaba 16 años, pero como no dice de dónde toma el dato, nos remitimos a la fecha que aparece en la recopilación de Remos.

42. Aparecen fecha y lugar de realización: "Bayamo, 8 de mayo de 1859." Fue publicada en El Kaleidoscopio. 
43. En la villa del Cobre dice Herrera de Herrera (N. pág.), nombre que se toma de las minas que están allí en explotación desde el siglo XVI.

44. María Salgado, en "Desenmarcando el cuadro: El autorretrato de Luisa Pérez de Zambrana," afirma: "nació entre 1835 y 1837" (220). Y tomando como base la "Introducción a la poesía de Luisa Pérez de Zambrana," de Ángel Huete, en Luisa Pérez de Zambrana. Poesías completas, explica "aunque no existe documentación, algunos críticos se guían por ciertas composiciones en las que Pérez declara tener diecisiete años en el momento de escribirlas" (cit. en Salgado 220).

45. Tomado de la foto de su tumba que aparece en el folleto de René León (19).

46. Si se utiliza aquí la crítica de Martí, es por la comparación que hace con Luisa Pérez de Zambrana, tan importante para conocer, en voz de un célebre intelectual masculino e hispanoamericano de su época, su visión de lo femenino, o más bien, de lo que correspondía o se esperaba de una mujer en su tiempo.

47. En ella se encuentra el santuario de la Virgen de la Caridad del Cobre, Patrona de Cuba, para la población católica de la Isla.

48. Maestro y protector de José Martí.

49. Antes de los 50 años muere su esposo, de tuberculosis. De sus hijos: Elodia, en 1886, a los 22 de tétanos; Angélica, en 1892, a los 33, de parto; Jesús, en 1893, a los veintisiete; Dulce María, en 1896, a los treinta y seis; y, por último, Ramón Horacio, también a los treinta y seis, en 1898 .

50. A menos que se indique lo contrario, los poemas de Luisa Pérez se escogieron de Antología poética, publicada en La Habana, por Letras Cubanas en 1977.

51. En la Antología poética de Luisa Pérez de Zambrana, selecionada por Chaple, aparece en una nota al pie de la página: "Antonio López (Nota de F. P. de Coronado)" (54). 
52. Según Max Henríquez Ureña, un hombre de pensamiento que no sólo visitó Santiago de Cuba, sino que residió allí por más de un año y entabló amistad con Luisa Pérez (311).

53. Este signo de interrogación, y otros que veremos a continuación, se encuentra así en la versión que manejamos.

54. En adelante nos referiremos a este trabajo como "El discurso."

55. Tomado de la carta inédita de Gertrudis Gómez de Avellaneda, expuesta en el capítulo I de esta investigación.

56. En su tomo Poesías, publicado por Gorgas y compañía en Barcelona, aparece que nació en el año 1841 (N. pág.) •

57. En su tomo Poesías, publicado por Gorgas y compañía en Barcelona, aparece que murió un día después, es decir, el 26 (N. pág.). Igual día señala Herrera de Herrera (N. pág. ) .

58. El año que da Cintio Vitier, en Los grandes románticos cubanos, es el 1874. Es decir, uno antes.

59. Alberto Rocasolano narra que en 1863 en el Liceo de Guanabacoa, fue leído su poema "El arroyo seco," (96), como no lo antologa, no sabemos si es el mismo que "A un arroyo seco," el cual aparece en el tomo I de Nicolás Azcárate, entre las páginas 53 y 55, y en Poesías, recopilación de Figarola y Caneda (33-34). Imaginamos que sí porque en el tomo de Figarola y Caneda, en cuya "Advertencia" se expresa que esta "obra [...] puede muy bien considerarse completa" (3), sólo aparece una composición que se refiere a un arroyo seco y ésta es, precisamente, la ya mencionada creación "A un arroyo seco."

60. Todos los poemas de Julia Pérez Montes de Oca, que aquí citaremos, se toman, precisamente de este tomo, Poesías, publicado, bajo la dirección de Domingo Figarola y Caneda, en Barcelona.

61. Estas negrillas aparecen en el original de Rocasolano. 
62. Estas negrillas aparecen en el original de Rocasolano.

63. Cabrera, citando a otros estudiosos, comenta al respecto:

[a]lgunos se atreven a indicar [...] la [...]

tuberculosis, la cual creían ver en la palidez de su piel y su delgadez. Otros, como Emilio Bacardí Moreau, dicen que "tras larga enfermedad fallece la dulce y sentida poetisa señorita Adelaida del Mármol..." (sic) y más adelante afirma que "enfermedad cruel e implacable arrebató a las justas esperanzas concebidas por los hijos de Santiago (41).

64. El Licenciado Zenovio Hernández Pavón, encargado de la Sala de Fondos Raros y Valiosos, de la Biblioteca Pública Provincial de Holguín, en carta al autor de este trabajo, añade: "considero que Delisa no fue su seudónimo, pues éste era el usado por Balbina García Copley, como afirma Portuondo. En varias publicaciones que he revisado aparecen poemas de Delisa y de Adelaida, de ahí que coincida con Portuondo aunque David [Cabrera Araújo] y el mismo Diccionario [de la literatura cubana] digan lo contrario. Es bueno aclarar, no obstante, que Cabrera hace mención del estudio de José Antonio Portuondo al respecto.

65. Aclara Cabrera Araújo que este apellido, escrito con "V," es de ortografía dudosa, que debe ser con "B," como aparece en la partida de bautismo de su hermana Isabel. Es decir, Ballagas (99).

66. Según datos que aparecen en La municipalidad holguinera/su creación y desenvolvimiento hasta 1799, de José A. García Castañeda, en 1815, veintitrés años antes del nacimiento de Adelaida del Mármol, la habitaban 15,396 personas (203).

67. Lorenza, una hermana del padre de Adelaida, casó con José Agustín García González, hermano de Ramón, el padre de Calixto García Iñiguez, una de las máximas figuras de las guerras por la independencia de Cuba durante el siglo XIX. Datos tomados del Fondo "García Castañeda," documentos 196-97-Folio 91 V, No. 520, del Museo Provincial de Historia de Holguín (cit. en Cabrera 12-13). 
68. Participó en las guerras de independencia de Cuba. En la de los Diez Años (1868-78) fue hecho prisionero y deportado a España. Regresó luego de la Paz del Zanjón de 1878. Organizó la Guerra Chiquita (1879); y fue jefe de Camagüey y Oriente durante la guerra de Independencia (1895-98). Presidió entonces las negociaciones con los Estados Unidos.

69. El Mayor General Donato Mármol Tamayo, hijo de Raymundo Mármol Valdés, hermano del padre de Adelaida, organizó la División de Santiago de Cuba, la más aguerrida, numerosa y disciplinada del Ejército Libertador que apoyó a Carlos Manuel de Céspedes en los primeros años de la guerra (Cabrera 13). Este investigador afirma, además, que Donato tuvo un hermano, Leonardo, que alcanzó el grado de general de brigada en 1868 .

70. Según el investigador Cabrera Araújo "[l]os Mármol es una familia de origen español, que estuvo vinculada al ejército realista como lo demuestra que numerosos de sus miembros fueran oficiales, enviados al Nuevo Mundo a combatir las huestes de Simón Bolívar" (13). También afirma Cabrera que, aunque no se conoce el monto de su fortuna, sus bienes debieron de ser considerables por la dotación de esclavos que tenían a su servicio (14).

71. Cabrera añade que Emilio luchó en la guerra de independencia de 1868, de la parte cubana; Ana murió muy joven y que Isabel nació en Holguín el 1 ro de febrero de 1836 (15).

72. Consejo de Guerra que también condenó a prisión a don Calixto García de Luna Izquierdo, abuelo del Mayor General Calixto García Íñiguez (Cabrera 17).

73. El poema de Byron, tomado de The Complete Poetical Works of Byron, es el siguiente: JEPHTHAS'S DAUGHTER

Since our Country, our God -Oh, my Sire!

Demand that thy daughter expire; Since thy triumph was bought by the vowStrike the bosom that's bared for thee now! 
And the voice of may mourning is o'er

And the mountains behold me no more:

If the hand that I love lay me low,

There cannot be pain in the blow!

And of this, oh, my Father! be sure-

That the blood of thy child is as pure

As the blessing I beg ere it flow,

And the last thought that soothes me below.

Though the virgins of Salem lament,

Be the judge and he hero unbent!

I have won the great battle for thee,

And my Father and Country are free!

When this blood of thy giving hath gush'd When the voice that thou lovest is hush'd, Let my memory still be thy pride,

And forget not I smiled as I died! (218)

La traducción de Adelaida del Mármol publicada por

Domitila García de Coronado en Album Poético Fotográfico de Escritoras y Poetisas Cubanas, es la siguiente:

La hija de Jepthe

Ya que Dios y mi patria, reclaman, padre mío, que exhale en su holocausto el hálito vital, y tú al formar tal voto compraste la victoria, ihiere mi débil seno tranquilo y virginal!

Cesaron mis lamentos llenos de amargura las cumbres no me deben volver a contemplar, sacrificada a la muerte por tu amada mano el golpe que me hiere recibo sin pesar.

No dudes, padre mío, la sangre de tu hija es pura cual la tierna y santa bendición que a tus plantas imploro, antes que corra aquella y es dulce cual la idea postrera de mi razón.

No vierten más sus quejas las hijas de Solima, la energía del héroe no truequen en piedad, en cambio de mi vida te ofrezco la victoria 
y mi padre y mi patria tendrán la libertad.

Cuando corra la sangre que debo a tu existencia

cuando la voz que amas no vuelvas a escuchar,

sea el recuerdo mío tu orgullo todavía

y piensa que vísteme sonreir al expirar. (133)

74. Aunque Zenovio Hernández Pavón dice en su carta: "En el periódico santiaguero El Redactor, con fecha 14 de junio de 1864, se afirma que Margarita era hermana de Adelaida y que había muerto en Barcelona, España. Adelaida en su poema "Madrigal" dice que es su sobrina. ¿Ésta sería la misma Margarita poeta o son dos diferentes?"

75. En el original de Ángel y Kate Flores no hay separación entre los versos. Adopto esta versión, con estrofas separadas, que aparece en el libro de Cabrera Araújo.

76. Esta coma no aparece en la versión del libro de Cabrera, página 37.

77. Aquí aparece una coma en el libro de Cabrera (37).

78. Coma, en el libro de Cabrera (37).

79. El investigador Luis A. Jiménez afirma que "iiEstá muerta!! se publicó en 1860, mientras que "Flores sobre su tumba," en 1861 (156).

80. Patriota cubano (1816-1851) que encabezó el alzamiento de 1851 .

81. Este signo único de interrogación aparece en el poema original y así consta además en las antologías de Rocasolano (110) y de Herrera de Herrera (232).

82. Todos los textos de Martina fueron tomados del tomo II del Florilegio de Escritoras Cubanas, de Antonio González Curquejo.

83. Androcles fue un esclavo romano, héroe de una aventura conmovedora referida por Aulo Gelio, autor de Noches áticas [...] precioso por el gran número de datos que encierra acerca de la literatura y las costumbres áticas (Pequeño Larousse) Págs. 986 y 1008. 
84. En Herrera de Herrera aparece aquí la palabra

"embotan."

85. Manuela Herrera de Herrera afirma que el libro se llamó en su primera edición Fabulas Morales. Afirmación que debe tenerse en cuenta pues se hizo en 1893, aún en vida de Aurelia Castillo.

86. Herrera de Herrera dice que el nombre de esta publicación es Revista de Cádiz (N. pág.).

87. Bustos y Rimas, el libro póstumo de Julian del Casal que se publicara gracias al empeño de Enrique Hernández Miyares el 21 de diciembre de 1893, consta de 41 poemas (o rimas) y de nueve estudios de importantes figuras de su tiempo (o Bustos).

88. Las otras son: Meredes Matamoros (1851-1906), y Nieves Xenes (1859-1915). A Arpas Cubanas aún hoy se le critica la omisión de Luisa Pérez de Zambrana (Max Henríquez Ureña 2: 277).

89. Estos versos aparecen en cursiva en el original.

90. En nota que aparece encima de estas traduciones, la autora aclara que fueron hechas por el Sr. Aurelio Morales (N. pág.).

91. Estos cuatro últimos versos aparecen en cursiva en el original.

92. En cursiva en el original.

93. Las cursivas aparecen en el original.

94. Estas cursivas aparecen en el original.

95. En el libro de Rocasolano, e incluso en Obras de Rosa Kruger que se publicó póstumamente, no se encuentra este segundo apellido, que sí aparece en Album Poético Fotográfico de Escritoras y Poetisas Cubanas, de Domitila García de Coronado, y se incorpora en Naturaleza y alma cubana. Dos siglos de poesía cubana (1760-1960), de Carlos Ripoll. En las obras de Rosa, publicadas en 1883, el primer apellido aparece Kruger, y no Krüeger, como lo escribe 
Rocasolano. En García de Coronado también aparecen sin la diéresis.

96. Si bien uno de sus antólogos refiere que se pensó publicar más de un tomo de su obra, en el libro utilizado, prestado por la Cuban Collection del Harvard College Library -por un sello gomígrafo de tal institución- se sabe que estaba allí desde el 3 de mayo de 1917-. En la portada de Obras de Rosa Kruger, aparece, en un espacio donde debió estar escrito: "Tomo primero," un recorte de papel, del mismo utilizado en la carátula, que hace desaparecer tal anuncio. En la página interior, con los mismos datos, se sabe, por los restos de goma que se observan, que se puso otro papel para que no se descifrara tal leyenda. Como no se habla de otros trabajos de esta autora, nos queda la duda de si realmente José Antonio Cortina tuvo en sus manos otros manuscritos que no logró dar a la luz pública.

97. Según Samuel Feijóo en Cantos a la naturaleza cubana del siglo XIX, dice tomar este poema del tomo "«Poesías»" de 1883. Realmente, el libro de esta autora,

correspondiente a tal año, se nombra Obras de Rosa Kruger y no Poesías. El resto de los textos de Kruger citados por Feijóo, sí aparecen en tal colección cuyos títulos y páginas son los siguientes: "La Nevada" (33), "A Cuba" (65), "El Crepúsculo" (107), "El Guardiero" (197). En Obras de Rosa Kruger, prologado póstumamente por José Antonio Cortina, que revisamos y utilizamos en esta investigación, no se encuentra la composición "La bijirita." Desconocemos de dónde el estudioso tomó, pues, tal trabajo y el por qué de su error.

98. Fue autor de Historia de los Reyes Católicos, Fernando e Isabel (1838); Historia de la conquista de México (1843); Historia de la conquista de Perú (1847), entre otros títulos.

99. Este segundo apellido se toma directamente de su libro de poesía donde aparece como Señorita $D^{a}$ SOFIA ESTEVEZ Y VALDÉS. Nombres y apellidos que aparecen con la ortografía anterior.

100. Así está en el original. 
101. Texto que no aparece en Lágrimas y sonrisas, el único libro que publicó.

102. Este dato fue tomado de "SOFIA ESTEVEZ Y VALDES," en el libro de esta autora. En el vol. 1, del Diccionario de la literatura cubana, aparece noviembre. Por cierto que en este último se menciona a Emilio Peyrellade como su fundador y como su editor, J. Federico Peyrellade. Domitila y Sofía aparecen como directoras y ésta, además, como su redactora.

103. Texto que tampoco se encuentra en su poemario de 1875.

104. Sofía Estévez sólo ocasionalmente puso la fecha correspondiente al pie de sus poemas, ésta es una de sus excepciones.

105. Varias de sus composiciones se llaman simplemente "Soneto." En Lágrimas y sonrisas, aparecen dos. Desconocemos si publicó otro, que no ha llegado hasta nuestros días, con tan simple nombre. Para diferenciarlos se escribe entre rayas (-), según la denominación de la Real Academia Española en su Esbozo de una nueva gramática de la lengua española, el primer verso de la obra.

106. Según Manuela Herrera de Herrera, Sebastián Alfredo de Morales era también literato (N. pág.).

107. Rocasolano también tiene esta fecha, aunque aclara que se han dado otras (123).

108. González Curquejo afirma que fue a los dieciséis (II: 167).

109. Fue el primer premio, según Rocasolano (123).

110. En "Safo a Faón," poema también de su primer poemario, tomará el nombre de la poeta griega y desde ella cantará a su enamorado.

111. Estos textos, donde no se especifica la obra de donde se han tomado, pertenecen al volumen Poesías, de 1866.

112. Según nota de la página 74 en la Antología poética de Luisa Pérez de Zambrana -La Habana: Letras Cubanas, 1977- 
este artículo aparece bajo el nombre de Orestes, seudónimo de Martí en la Revista Universal. 
LUIS MARCELINO GÓMEZ

April 26, 1950

1975

$1976-1977$

$1978-1979$

$1980-1982$

$1983-1987$

1985

$1989-1992$

1993

$1994-1995$

1995

1996

1998-2001

1999
Born, Holguín, Cuba.

Medical Doctor:

University of Oriente, Cuba

Public Health Department. Cueto, Holguín, Cuba. Regional Medical Director

Nat. Teaching Hosp. Manuel Fajardo. Habana, Cuba. Residency in Internal Medicine

Angola, Africa. Medical Team.

Nat. Teaching Hosp. Enrique Cabrera. Cuba Residency in Psychiatry \& Psychiatrist

National Short Story Award. Cuba.

Hialeah Hospital, Miami. Subs. Abuse Tech.

Dr. Mario Cuervo (Physician's Assistant)

Brockway Memorial Library (Librarian Ast. )

B.A., Spanish

Florida International University

M.A., Spanish

Florida International University

Ph.D. Candidate

Florida International University

Excellence in Teaching Award

HONORS

.Ph.D. comprenhensive exam with honor. Nov, 1998. FIU. - Member of The Honor Society of Phi Kappa Phi. 
. Master comprehensive exam with honor. Nov, 1996. FIU. - Dean's List: Summer term 95

Spring term 95

Fall term 94

PUBLICATIONS

1994 Book Donde el sol es más rojo. Miami: La torre de papel. Short stories collection.

1998 Book Canción a solo. Brasil: Thesaurus Editora de Brasilia. 1998. Poetry.

1999 Book Hambre de pez. Madrid: Editorial Betania. Poetry. 